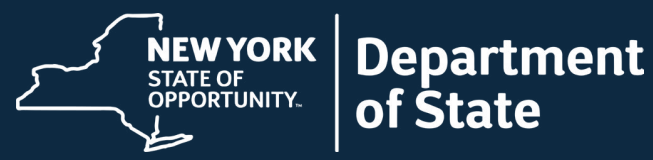

\title{
Long Island South Shore Estuary Reserve Coordinated Water Resources Monitoring Strategy
}

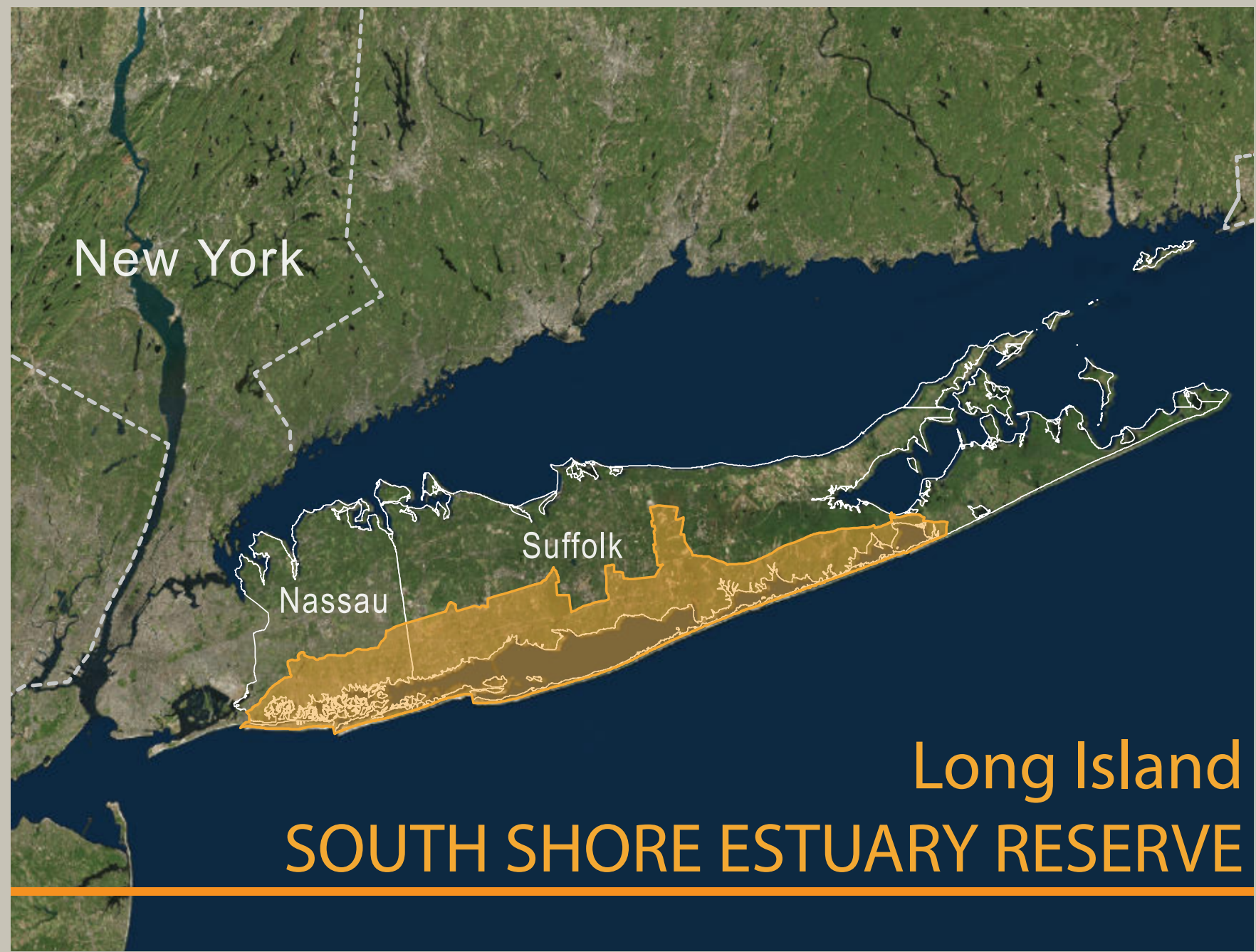

Open-File Report 2017-1161

U.S. Department of the Interior U.S. Geological Survey 
Cover. The Long Island South Shore Estuary Reserve (orange) stretches west to east from the Nassau-Queens county line to the town of Southampton. South to north, it extends from mean high tide on the ocean side of the barrier islands to the inland limits of the watersheds that drain into the bays. Image courtesy of the New York State Department of State Office of Planning, Development and Community Infrastructure. 


\section{Long Island South Shore Estuary Reserve Coordinated Water Resources Monitoring Strategy}

By Shawn C. Fisher, Robert J. Welk, and Jason S. Finkelstein

Prepared in cooperation with the

New York State Department of State Office of Planning,

Development and Community Infrastructure and the

South Shore Estuary Reserve Office

Open-File Report 2017-1161 


\section{U.S. Department of the Interior \\ RYAN K. ZINKE, Secretary}

\section{U.S. Geological Survey James F. Reilly II, Director}

\section{U.S. Geological Survey, Reston, Virginia: 2018}

For more information on the USGS - the Federal source for science about the Earth, its natural and living resources, natural hazards, and the environment-visit https://www.usgs.gov or call 1-888-ASK-USGS.

For an overview of USGS information products, including maps, imagery, and publications, visit https://store.usgs.gov.

Any use of trade, firm, or product names is for descriptive purposes only and does not imply endorsement by the U.S. Government.

Although this information product, for the most part, is in the public domain, it also may contain copyrighted materials as noted in the text. Permission to reproduce copyrighted items must be secured from the copyright owner.

Suggested citation:

Fisher, S.C., Welk, R.J., and Finkelstein, J.S., 2018, Long Island South Shore Estuary Reserve Coordinated Water Resources Monitoring Strategy: U.S. Geological Survey Open-File Report 2017-1161, 105 p., https://doi.org/10.3133/ ofr20171161.

ISSN 2331-1258 (online) 


\section{Foreword}

The original Long Island South Shore Estuary Reserve Coordinated Water Resources Monitoring Strategy (CWRMS), written in 2000, was part of a series of technical reports prepared as baseline information to support the creation of the 2001 South Shore Estuary Reserve Comprehensive Management Plan. This updated CWRMS, as noted in the executive summary, "provides an overview of the water-quality and ecological monitoring within the Reserve and presents suggestions from stakeholders for future data collection, data management, and coordination among monitoring programs."

Many issues and challenges exist in the South Shore Estuary Reserve today that were not present or were not as extensive when the original CWRMS was written. Priority issues such as nitrogen and phosphorus pollution, low dissolved oxygen, bay-water acidification, harmful algal blooms, pathogens, sedimentation, microplastics, groundwater contamination from pharmaceuticals and personal care products, and fertilizer, pesticide, and herbicide pollution prompted the South Shore Estuary Reserve Council and the New York Department of State to create this updated CWRMS.

A series of group meetings, a public workshop, and individual meetings were held with members of the Project Advisory Committee (PAC). This PAC consisted of representatives of the New York State Department of State, the South Shore Estuary Reserve Council, the South Shore Estuary Reserve Citizens Advisory Committee, academia, watershed groups, environmental groups, the U.S. Environmental Protection Agency, the U.S. Fish and Wildlife Service, county soil and water conservation districts, the National Park Service, the U.S. Army Corps of Engineers, and the U.S. Geological Survey, who all made this updated strategy possible with their considerable experience and expertise in water-quality issues and monitoring protocols.

The New York State Department of State entered into a cooperative agreement with the U.S. Geological Survey New York Water Science Center to produce the 2017 CWRMS and coordinate the project. The USGS project staff included Christopher Schubert, Shawn Fisher, Robert Welk, and Jason Finkelstein; their expert technical qualifications and experience in water-quality, groundwater, and surface-water issues led to the production of this CWRMS.

It is our hope that the many stakeholders who are involved with water-quality and ecological monitoring efforts will find this document pertinent, useful, and timely as it relates to the issues that exist in today's South Shore Estuary Reserve.

New York State Department of State/Office of Planning, Development and Community Infrastructure and

The South Shore Estuary Reserve Office 



\section{Acknowledgments}

Several of our colleagues at the New York State Department of State Office of Planning, Development, and Community Infrastructure provided valuable assistance, advice, and exceptional contributions to the content of this report. These colleagues include Nancy Rucks, Myra Fedyniak, Sherry Forgash, Lou Siegel, and Jeremy Campbell. Cooperation from the Long Island South Shore Estuary Reserve Council with support from the New York State Environmental Protection Fund is gratefully acknowledged. 



\section{Contents}

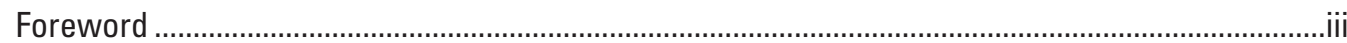

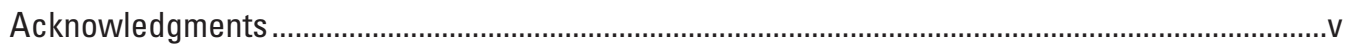

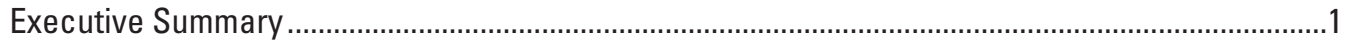

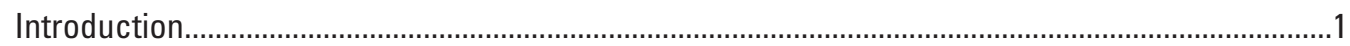

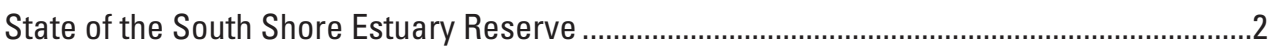

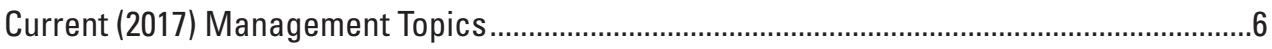

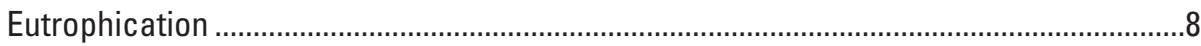

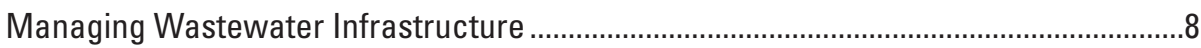

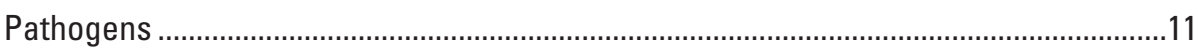

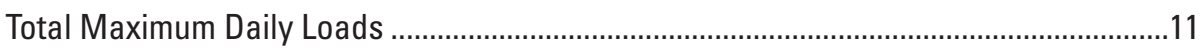

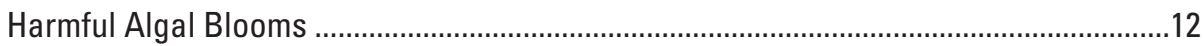

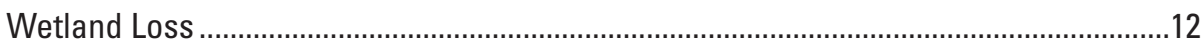

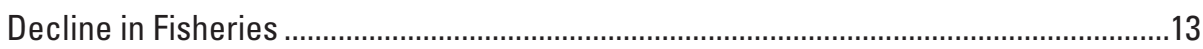

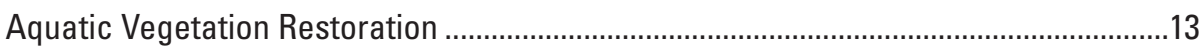

Climate Change and Resiliency .................................................................................

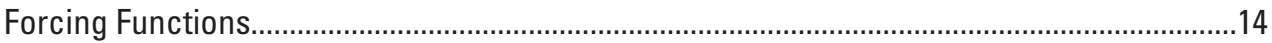

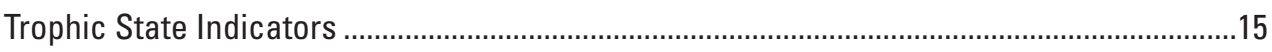

Low-Impact Development and Best Management Practices ................................................17

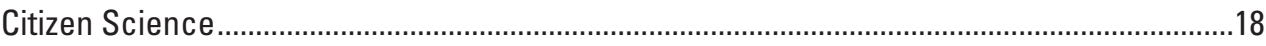

Synergy Among Existing Management and Action Plans ................................................18

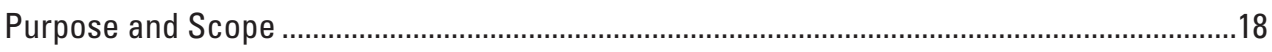

Resource Monitoring in the Long Island South Shore Estuary Reserve .......................................18

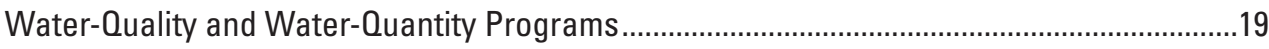

Continuous Water-Quality Monitoring.......................................................................19

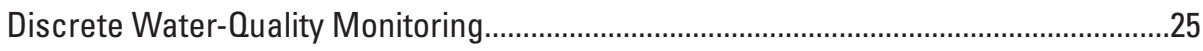

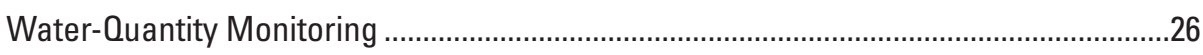

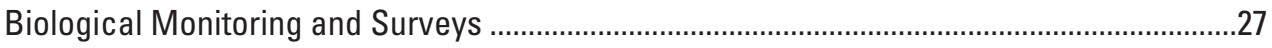

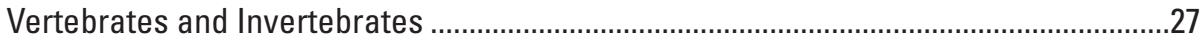

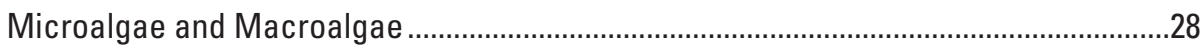

Wildlife

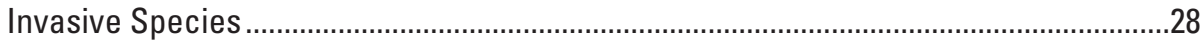

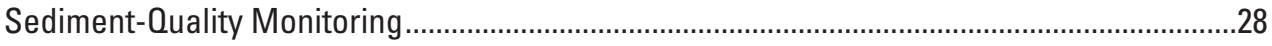

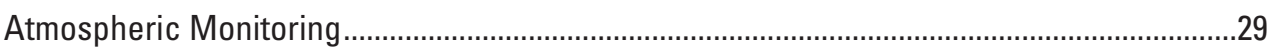

Quality Assurance and Quality Control, Metadata, and Data Archives ..........................................29

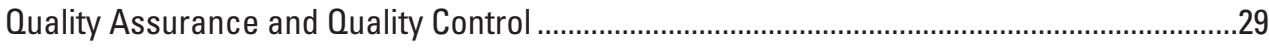

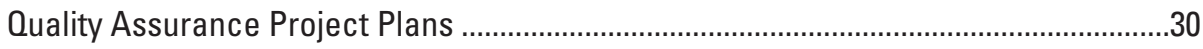

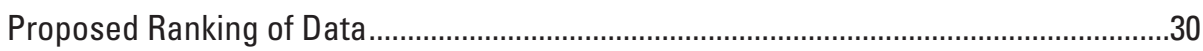

Defining and Standardizing Metadata ...............................................................................

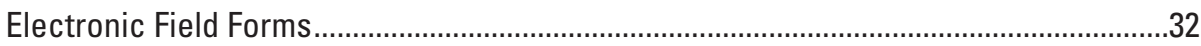

Metadata Database .....................................................................................................

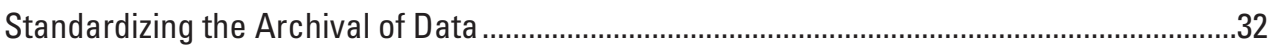

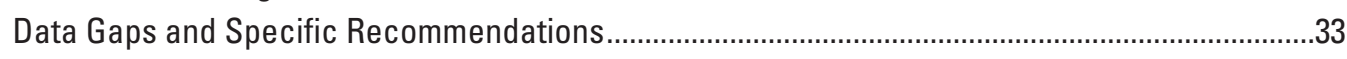

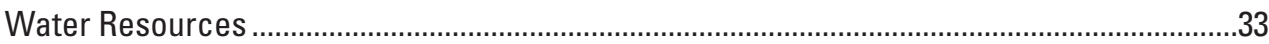




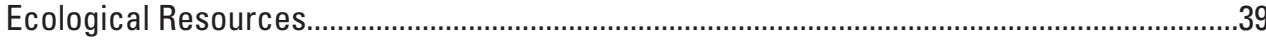

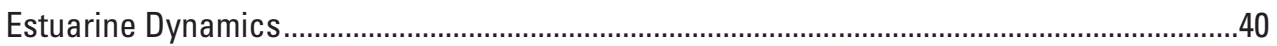

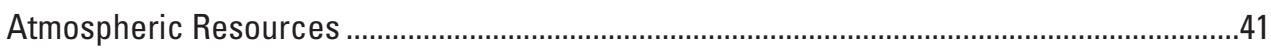

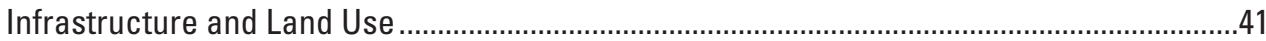

General and Coordination Recommendations From the Project Advisory Committee ....................42

General Recommendations of the Project Advisory Committee ..............................................42

Recommendations for Stakeholder Coordination by the Project Advisory Committee ...........46

Coordinated Water Resources Monitoring Strategy Website ............................................................47

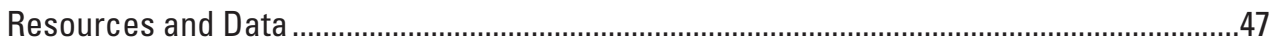

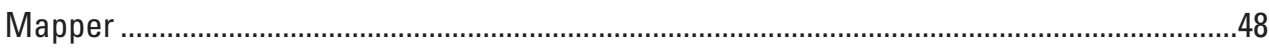

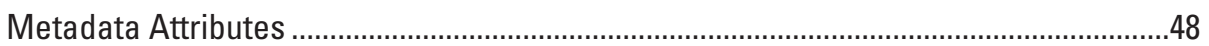

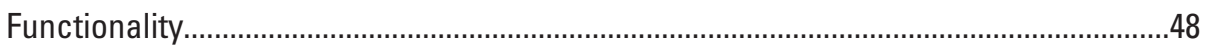

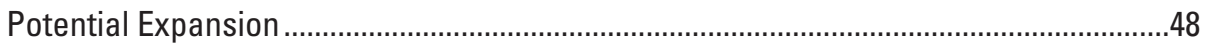

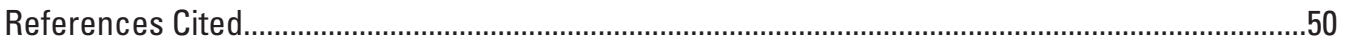

Appendix 1. Updates to Recommendations Presented in the 2000 Coordinated Water

Resources Monitoring Strategy.....................................................................................

Appendix 2. New York State Department of Environmental Conservation 303(d) List of

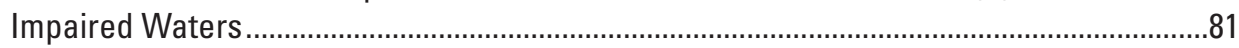

Appendix 3. Expanded List of Management Plans Created or in Progress for Resources Within the Long Island South Shore Estuary Reserve, New York.......................................89

Appendix 4. Members of the Project Advisory Committee for the Long Island South Shore Estuary Reserve 2017 Coordinated Water Resources Monitoring Strategy ........................93

Appendix 5. Notes From the South Shore Estuary Reserve Coordinated Water Resources Management Strategy Project Advisory Committee Meetings.............................................97

\section{Figures}

1. Map showing political boundary of the South Shore Estuary Reserve, Long Island, New York

2. Map showing ongoing and proposed monitoring in the western bays of the South Shore Estuary Reserve, New York.

3. Map showing ongoing and proposed monitoring in the Great South Bay of the South Shore Estuary Reserve, New York.

4. Map showing ongoing and proposed monitoring in the eastern bays of the South Shore Estuary Reserve, New York.

5. Screenshot of the South Shore Estuary Reserve Coordinated Water Resources Monitoring Strategy website mapper 


\section{Tables}

1. Constituents collected or proposed for monitoring of water or ecological resources in the South Shore Estuary Reserve, New York...

2. Management plans for water or ecological resources in the South Shore Estuary Reserve, New York

3. Management issues identified by the Project Advisory Committee for the South Shore Estuary Reserve Coordinated Water Resources Monitoring Strategy.....

4. List of water-quality and ecological monitoring programs ongoing or completed since 2000 in the South Shore Estuary Reserve, New York, with information on A, objectives and constituents and $B$, quality assurance and quality control, timeframes, and URLs....

5. List of projects relevant to water quality and ecological health ongoing or completed since $\mathbf{2 0 0 0}$ in the South Shore Estuary Reserve, New York.....

6. Partial list of field equipment used or deployed for water-quality monitoring in the South Shore Estuary Reserve, New York...

7. List of gaps in data collection programs identified and prioritized by the Project Advisory Committee for the Long Island South Shore Estuary Reserve Coordinated Water Resources Monitoring Strategy.

\section{Conversion Factors}

U.S. customary units to International System of Units

\begin{tabular}{lcl}
\hline \multicolumn{1}{c}{ Multiply } & By & \multicolumn{1}{c}{ To obtain } \\
\hline inch (in.) & 2.54 & centimeter $(\mathrm{cm})$ \\
inch (in.) & 25.4 & millimeter $(\mathrm{mm})$ \\
foot (ft) & 0.3048 & meter $(\mathrm{m})$ \\
mile (mi) & 1.609 & kilometer $(\mathrm{km})$ \\
acre & 0.4047 & hectare $(\mathrm{ha})$ \\
gallon per day (gal/d) & 3.785 & liter per day $(\mathrm{L} / \mathrm{d})$ \\
inch per year (in/yr) & 2.54 & centimeter per year $(\mathrm{cm} / \mathrm{yr})$ \\
inch per year (in/yr) & 25.4 & millimeter per year $(\mathrm{mm} / \mathrm{yr})$ \\
\hline
\end{tabular}

\section{Datum}

Vertical coordinate information is referenced to the North American Vertical Datum of 1988 (NAVD 88) or the National Geodetic Vertical Datum of 1929 (NGVD 29).

Horizontal coordinate information is referenced to the North American Datum of 1983 (NAD 83).

Elevation, as used in this report, refers to distance above the vertical datum. 


\section{Abbreviations}

\begin{tabular}{|c|c|}
\hline BMP & best management practice \\
\hline CERCOM & Center for Environmental Research and Coastal Oceans Monitoring \\
\hline CMP & Comprehensive Management Plan \\
\hline CWRMS & Coordinated Water Resources Monitoring Strategy \\
\hline EPA & U.S. Environmental Protection Agency \\
\hline FEMA & Federal Emergency Management Agency \\
\hline FWS & U.S. Fish and Wildlife Service \\
\hline GIS & geographic information system \\
\hline GOSR & Governor's Office of Storm Recovery \\
\hline GPS & Global Positioning System \\
\hline$H A B$ & harmful algal bloom \\
\hline lidar & light detection and ranging \\
\hline LINAP & Long Island Nitrogen Action Plan \\
\hline LISS & Long Island Sound Study \\
\hline MS4 & municipal separate storm sewer system \\
\hline NOAA & National Oceanic and Atmospheric Administration \\
\hline NPS & National Park Service \\
\hline NWIS & National Water Information System \\
\hline NYS & New York State \\
\hline NYSDEC & New York State Department of Environmental Conservation \\
\hline NYSDOS & New York State Department of State \\
\hline PAC & Project Advisory Committee \\
\hline PAH & polycyclic aromatic hydrocarbon \\
\hline PCB & polychlorinated biphenyl \\
\hline PEP & Peconic Estuary Program \\
\hline PPCP & pharmaceuticals and personal care products \\
\hline QA/QC & quality assurance and quality control \\
\hline QAPP & quality assurance project plan \\
\hline SAV & submerged aquatic vegetation \\
\hline SCDHS & Suffolk County Department of Health Services \\
\hline SET & surface elevation table \\
\hline SoMAS & Stony Brook University School of Marine and Atmospheric Sciences \\
\hline SSER & South Shore Estuary Reserve \\
\hline STORET & Storage and Retrieval \\
\hline
\end{tabular}




$\begin{array}{ll}\text { TMDL } & \text { total maximum daily load } \\ \text { TNC } & \text { The Nature Conservancy } \\ \text { TSI } & \text { trophic state indicator } \\ \text { USACE } & \text { U.S. Army Corps of Engineers } \\ \text { USGS } & \text { U.S. Geological Survey } \\ \text { WQX } & \text { Water Quality Exchange }\end{array}$





\title{
Long Island South Shore Estuary Reserve Coordinated Water Resources Monitoring Strategy
}

\author{
By Shawn C. Fisher, Robert J. Welk, and Jason S. Finkelstein
}

\section{Executive Summary}

The Long Island South Shore Estuary Reserve Coordinated Water Resources Monitoring Strategy (CWRMS) provides an overview of the water-quality and ecological monitoring within the Reserve and presents suggestions from stakeholders for future data collection, data management, and coordination among monitoring programs. The South Shore Estuary Reserve, hereafter referred to as the Reserve, is a 173-square-mile network of bays and tributaries shaped by the south shore of Long Island (New York) and the barrier islands that was formed as a result of the last ice age (roughly 18,000 years ago). This overview and coordination document is based on information assembled from a series of meetings, a workshop, and individual correspondences with the CWRMS Project Advisory Committee, which was formed in 2015 to help guide the creation of the document, which reflects the current (2017) status of the Reserve and the need for additional data to address its water-quality issues and ecological health and to respond to a changing climate. The U.S. Geological Survey (USGS), in cooperation with the New York State Department of State Office of Planning, Development and Community Infrastructure and the South Shore Estuary Reserve Office, compiled information and recommendations to help stakeholders efficiently evaluate waters currently being monitored and address areas where necessary data are lacking. Water-quality monitoring in the Reserve is ongoing on the Federal, State, and local levels, and coordination among the various programs administered by the U.S. Environmental Protection Agency; National Oceanic and Atmospheric Administration; USGS; Shinnecock Tribal Nation; New York State; Nassau and Suffolk Counties; the Towns of Hempstead, Oyster Bay, Babylon, Islip, Brookhaven, and Southampton; and local universities and nonprofit organizations is necessary to ensure cooperation and efficient use of limited resources. Proper collection and archival of data are critical to the usability of data and methods - a sample of available repositories for monitoring data are provided in this report. Equally important are quality assurances of data and proper techniques of archival such that water and ecological data are collected and analyzed in a consistent manner, regardless of their sources, and that differences in methodologies are identified that might result in discrepancies in the compiled data. Details on monitoring programs, data gaps that are perceived by stakeholders and researchers in the area, and Project Advisory Committee recommendations are provided in this report to promote discussion and coordination. In most cases, resources to fill data gaps are needed, and the use of citizen science volunteers has been shown to help extend programs and provide insight into previously unaddressed areas of concern. This document, in conjunction with the CWRMS website and interactive mapper, is intended to inform the latest iteration of the Comprehensive Management Plan for the Reserve. Moreover, resource managers can use the CWRMS and mapper to identify areas of potential overlap and initiate conversations with stakeholders about addressing needs for additional monitoring of water quality and ecological health in the bays and tributaries of the Reserve.

\section{Introduction}

Since the Long Island South Shore Estuary Reserve Comprehensive Management Plan (CMP) was approved in 2001, much has been learned regarding the man-made and natural contributors that led to the impaired status of many of the bays and tributaries of the South Shore Estuary Reserve (hereafter referred to as the Reserve) in Long Island, New York. As a result, efforts are underway to improve ecological health and restore natural resources to the Reserve while improving its resiliency. The CMP lists objectives for the estuary system, including improving and subsequently maintaining water quality, restoring and protecting living resources, expanding public use and enjoyment, improving and sustaining the economy, community resiliency, and increasing education, outreach, and stewardship. These objectives are based on information that predates an increased frequency of algal blooms, two hurricanes, and the realization that groundwater is contributing most of the nutrients to the bays. The U.S. Geological Survey (USGS) and the New York State Department of State (NYSDOS) Office of Planning, Development and Community Infrastructure and the South Shore Estuary Reserve Office worked with local and regional stakeholders to develop a new Coordinated Water Resources Monitoring Strategy (CWRMS) for the Reserve with three complementary components: this written report, the project web page, and an interactive mapper. 
- Report: Since 2000, when the last CWRMS was published, numerous research projects and studies have identified new effects on the ecological health and resilience of the Reserve. Many of the recommendations outlined in the 2000 CWRMS were followed, while others were not, and a summary of the data gaps and recommendations is presented in appendix 1. This updated CWRMS highlights major changes since 2000 that affect water-resource management in the Reserve and the significance of recent developments to Reserve waterbodies. The updated CWRMS also offers recommendations based on perceived data gaps and resource-management concerns that have been raised by members of the Project Advisory Committee (PAC) and other stakeholders. Lastly, the updated CWRMS offers recommendations on the collection of metadata and a guide for proper quality assurance and quality control (QA/QC) documentation of field and laboratory data.

- Web page: The USGS Coordinated Water Resources Monitoring Strategy web page (https://doi.org/10.5066/ F7JQ0Z46) has been established to provide a comprehensive perspective of the monitoring programs and relevant studies within the Reserve. (A temporary project website [http://www.sserwaterquality.us] was established at the onset of the project [2014] and remained active until 2017 to provide project updates, an interim mapper, and forum for PAC members to provide resources and exchange ideas about the project.) The USGS CWRMS web page directs researchers, stakeholders, and the public to relevant documents and monitoring data and allows these resources to be sorted by type and constituent. The CWRMS report and the tables and references associated with the report can be downloaded. Additional resources, such as links to reports and information about the Reserve, are provided through a link to the NYSDOS South Shore Estuary Reserve website (NYSDOS, 2017). The USGS CWRMS web page also links to the interactive mapper developed for the CWRMS.

- Mapper: The interactive mapper (https://ny.water.usgs. gov/maps/sser/) aggregates available study information from government agencies, academic institutions, stakeholders, and citizen scientists and provides links (or contact information) for users to obtain available data. This information is provided in the context of an organization's monitoring network and the associated water-quality constituents or ecological data collected. Each of the features can be queried to obtain more information about the site, and all information can be exported (downloaded). The information provided can be filtered on the basis of water-quality constituent being collected or analyzed at the site, the datacollection organization, whether data are publicly available or not, and other search parameters. Other features include the watershed boundaries using 12-digit hydrologic unit codes (HUC12), the National Oceanic and Atmospheric Administration bathymetry layer of most bays of the Reserve, a list of New York State Department of Environmental Conservation (NYSDEC) impaired waters, and NYSDEC shellfish areas.

Though some coordination exists, organizations differ in how they are collecting, recording, and archiving waterquality and ecological data within the Reserve. To address this, a Project Advisory Committee was assembled in 2015 to help guide the creation of this CWRMS, which provides updates on programs and recommendations on activities within the Reserve to address its poor (defined in this report as not meeting established criteria or standards for a given resource) water quality and ecological health. This CWRMS provides a stakeholder-defined list of physical, chemical, and biological constituents (table 1) that are either currently being measured (2017) or are recommended to be measured at select locations throughout the Reserve to assess overall ecological health of the contributing systems (surface water, groundwater, land and air resources). This list is based on regulations and infrastructure improvements. Many of the constituents are being collected to address management issues, and the list is for improving efficiencies in the data collection effort. The goal is for organizations collecting these data to be coordinated around the same objectives with data delivered through a readily accessible public platform.

\section{State of the South Shore Estuary Reserve}

The Reserve is a 173-square-mile network of bays and tributaries shaped by the south shore of Long Island (New York) and the barrier islands that was formed as a result of the last ice age (roughly 18,000 years ago). The Reserve receives salt water from the Atlantic Ocean through five inlets in the barrier islands and freshwater from groundwater and over one hundred rivers and streams. Natural and anthropogenic contaminants have been detected in these source waters, as well as direct land runoff and atmospheric deposition, and thus have been attributed to the decline in estuarine health.

Efforts to improve the water quality of coastal waters throughout the State of New York have been ongoing for decades. Prioritization of waters identified as impaired by pathogens, nutrients, and other factors contributing to eutrophication and closures of areas to shellfishing has allowed the NYSDEC to focus resources on areas of greatest need, particularly in the Reserve.

The 2014 NYSDEC list of impaired waters, 303(d), identifies 49 waterbodies of the Reserve as being impaired, mainly by nutrients, sediment, and pathogens (NYSDEC, 2014d). See appendix 2 for the list of Reserve waterbodies and impairments. Most waters have been slated for the development of either a total maximum daily load (TMDL) or a comprehensive assessment since being listed, and seven have been completed. Further, nine watersheds or waterbodies 
Table 1. Constituents collected or proposed for monitoring of water or ecological resources in the South Shore Estuary Reserve, New York.

[A constituent may be considered a trophic state indicator (TSI) and (or) a forcing function (FF) on the basis of descriptions provided in the introduction of the report. Constituent codes are abbreviations used to cross-reference tables in this report and for the filter function of the website. N, nitrogen; P, phosphorus; PAH, polycyclic aromatic hydrocarbon; VOC, volatile organic compound; lidar, light detection and ranging; SAV, submerged aquatic vegetation; TNC, The Nature Conservancy; USGS, U.S. Geological Survey; NYSDEC, New York State Department of Environmental Conservation; SoMAS, Stony Brook University School of Marine and Atmospheric Sciences; EPA, U.S. Environmental Protection Agency; NOAA, National Oceanic and Atmospheric Administration; Seatuck, Seatuck Environmental Association; SPLASH, Operation SPLASH; FWS, U.S. Fish and Wildlife Service; NPS, National Park Service; NWS, National Weather Service; NYSDOT, New York State Department of Transportation; --, not applicable]

\begin{tabular}{|c|c|c|c|c|}
\hline Constituent & $\begin{array}{l}\text { Constituent } \\
\text { code }\end{array}$ & $\begin{array}{l}\text { Trophic state } \\
\text { indicator tier/ } \\
\text { forcing functions }\end{array}$ & $\begin{array}{c}\text { Related biological } \\
\text { ecological indicators/ } \\
\text { sentinels } \\
\text { (if applicable) }\end{array}$ & $\begin{array}{l}\text { Synergy-organizations with current } \\
\text { or proposed monitoring }\end{array}$ \\
\hline \multicolumn{5}{|c|}{ Water } \\
\hline Water temperature & WT & $\mathrm{FF}$ & Finfish, shellfish, SAV & $\begin{array}{l}\text { TNC, USGS, NYSDEC, SoMAS, Suffolk } \\
\text { County }\end{array}$ \\
\hline $\mathrm{pH}$ & $\mathrm{pH}$ & -- & Shellfish & TNC, USGS, NYSDEC \\
\hline Alkalinity & ALK & -- & Shellfish & $\begin{array}{l}\text { USGS, Suffolk County, Town of Hempstead, } \\
\text { SoMAS }\end{array}$ \\
\hline Water level (surface water) & WL & $\mathrm{FF}$ & Wetlands, grasses & $\begin{array}{l}\text { USGS, Suffolk County, Town of Hempstead, } \\
\text { SoMAS }\end{array}$ \\
\hline Flow & FLOW & $\mathrm{FF}$ & Wetlands, grasses & $\begin{array}{l}\text { USGS, Suffolk County, Town of Hempstead, } \\
\text { SoMAS }\end{array}$ \\
\hline Groundwater level & GWL & -- & -- & USGS, Suffolk County, Nassau County \\
\hline Depth to bottom (surface water) & DEPTH & -- & -- & $\begin{array}{l}\text { USGS, Suffolk County, Town of Hempstead, } \\
\text { NYSDEC, TNC, SoMAS }\end{array}$ \\
\hline Salinity/conductivity & SAL & -- & Finfish, shellfish & $\begin{array}{l}\text { USGS, Suffolk County, Town of Hempstead, } \\
\text { SoMAS }\end{array}$ \\
\hline Chlorophyll $a$ & CHL & TSI primary & Finfish, shellfish & $\begin{array}{l}\text { USGS, Suffolk County, Town of Hempstead, } \\
\text { SoMAS }\end{array}$ \\
\hline Turbidity & TURB & -- & Finfish, shellfish, SAV & $\begin{array}{l}\text { USGS, Suffolk County, Town of Hempstead, } \\
\text { SoMAS }\end{array}$ \\
\hline $\begin{array}{l}\text { Photosynthetically active radia- } \\
\text { tion/light penetration }\end{array}$ & PAR & $\mathrm{FF}$ & Finfish, shellfish, SAV & SoMAS, Suffolk County \\
\hline Clarity/Secchi depth & CLAR & -- & Finfish, shellfish, SAV & $\begin{array}{l}\text { USGS, Suffolk County, Town of Hempstead, } \\
\text { SoMAS, NYSDEC }\end{array}$ \\
\hline Dissolved oxygen & DO & TSI secondary & Finfish, shellfish, SAV & $\begin{array}{l}\text { USGS, Suffolk County, Town of Hempstead, } \\
\text { SoMAS }\end{array}$ \\
\hline Suspended sediments & SS & -- & Wetlands & -- \\
\hline Nutrients ( $\mathrm{N}$ and $\mathrm{P}$; general) & NUT & $\mathrm{FF}$ & Wetlands, grasses & $\begin{array}{l}\text { USGS, Suffolk County, Town of Hempstead, } \\
\text { SoMAS, NYSDEC }\end{array}$ \\
\hline Orthophosphate & OP & -- & Wetlands, grasses & $\begin{array}{l}\text { Suffolk County, Town of Hempstead, } \\
\text { SoMAS, NYSDEC }\end{array}$ \\
\hline Total phosphorus & $\mathrm{TP}$ & -- & Wetlands, grasses & $\begin{array}{l}\text { Suffolk County, Town of Hempstead, } \\
\text { SoMAS, NYSDEC }\end{array}$ \\
\hline Nitrate (and nitrite) & NO3 & -- & Wetlands, grasses & $\begin{array}{l}\text { USGS, Suffolk County, Town of Hempstead, } \\
\text { Nassau County, SoMAS, NYSDEC }\end{array}$ \\
\hline Ammonia (and ammonium) & NH3 & -- & Wetlands, grasses & $\begin{array}{l}\text { Suffolk County, Town of Hempstead, Nassau } \\
\text { County, SoMAS, NYSDEC }\end{array}$ \\
\hline Total Kjeldahl nitrogen & TKN & -- & Wetlands, grasses & $\begin{array}{l}\text { Suffolk County, Town of Hempstead, Nassau } \\
\text { County, NYSDEC }\end{array}$ \\
\hline Fecal indicator bacteria & FIB & -- & Wetlands, grasses & Suffolk County, Town of Hempstead \\
\hline Pathogens & PATH & $\mathrm{FF}$ & -- & NYSDEC \\
\hline
\end{tabular}


Table 1. Constituents collected or proposed for monitoring of water or ecological resources in the South Shore Estuary Reserve, New York.-Continued

[A constituent may be considered a trophic state indicator (TSI) and (or) a forcing function (FF) on the basis of descriptions provided in the introduction of the report. Constituent codes are abbreviations used to cross-reference tables in this report and for the filter function of the website. N, nitrogen; P, phosphorus; PAH, polycyclic aromatic hydrocarbon; VOC, volatile organic compound; lidar, light detection and ranging; SAV, submerged aquatic vegetation; TNC, The Nature Conservancy; USGS, U.S. Geological Survey; NYSDEC, New York State Department of Environmental Conservation; SoMAS, Stony Brook University School of Marine and Atmospheric Sciences; EPA, U.S. Environmental Protection Agency; NOAA, National Oceanic and Atmospheric Administration; Seatuck, Seatuck Environmental Association; SPLASH, Operation SPLASH; FWS, U.S. Fish and Wildlife Service; NPS, National Park Service; NWS, National Weather Service; NYSDOT, New York State Department of Transportation; --, not applicable]

\begin{tabular}{|c|c|c|c|c|}
\hline Constituent & $\begin{array}{l}\text { Constituent } \\
\text { code }\end{array}$ & $\begin{array}{l}\text { Trophic state } \\
\text { indicator tier/ } \\
\text { forcing functions }\end{array}$ & $\begin{array}{c}\text { Related biological } \\
\text { ecological indicators/ } \\
\text { sentinels } \\
\text { (if applicable) }\end{array}$ & $\begin{array}{l}\text { Synergy-organizations with current } \\
\text { or proposed monitoring }\end{array}$ \\
\hline \multicolumn{5}{|c|}{ Water-Continued } \\
\hline Total organic carbon & TOC & -- & Wetlands, grasses & Suffolk County, Town of Hempstead, SoMAS \\
\hline Total organic nitrogen & TON & -- & Wetlands, grasses & Suffolk County, Town of Hempstead, SoMAS \\
\hline Major ions & ION & -- & -- & -- \\
\hline $\begin{array}{l}\text { Fluorescent dissolved organic } \\
\text { matter }\end{array}$ & fDOM & -- & Wetlands & -- \\
\hline Oxidation-reduction potential & ORP & -- & -- & Shinnecock Tribal Nation \\
\hline $\begin{array}{l}\text { Contaminants of emerging concern } \\
\text { (pharmaceuticals, personal care } \\
\text { and domestic-use products, and } \\
\text { hormones) }\end{array}$ & CEC & -- & Finfish, shellfish & USGS, SoMAS \\
\hline $\begin{array}{l}\text { Primary pollutants (such as PAHs, } \\
\text { VOCs, metals, pesticides) }\end{array}$ & PPOL & -- & Finfish, shellfish & USGS, NYSDEC, EPA, NOAA \\
\hline Perchlorate & $\mathrm{ClO} 4$ & -- & -- & USGS, Nassau County \\
\hline Microplastics & MP & -- & Finfish, shellfish & -- \\
\hline Radionuclides & RADIO & -- & Finfish, shellfish & SoMAS \\
\hline Isotope analyses & ISOT & -- & -- & USGS, SoMAS \\
\hline \multicolumn{5}{|c|}{ Ecology } \\
\hline $\begin{array}{l}\text { Nuisance algae (including harmful } \\
\text { algal blooms) }\end{array}$ & $\mathrm{NA} / \mathrm{HAB}$ & TSI secondary, FF & Finfish, shellfish & SoMAS, Suffolk County \\
\hline Algal toxins (chemical) & ATOX & $\mathrm{FF}$ & Finfish, shellfish & SoMAS \\
\hline Macroalgae & MA & TSI primary & Finfish, shellfish & TNC, Town of Hempstead \\
\hline Subaquatic vegetation & SAV & TSI secondary & -- & $\mathrm{TNC}$ \\
\hline Vegetation survey & VEG & -- & -- & $\begin{array}{l}\text { TNC, Town of Brookhaven, NYSDEC, } \\
\text { Seatuck }\end{array}$ \\
\hline Bed sediment quality & $\mathrm{BS}$ & -- & Finfish, shellfish & SoMAS \\
\hline Litter & LITTER & -- & $\begin{array}{l}\text { Finfish, shellfish, } \\
\text { wetlands }\end{array}$ & SPLASH, EPA \\
\hline Plankton inventory & PLANK & -- & -- & SoMAS \\
\hline Nekton inventory & NEKT & -- & -- & -- \\
\hline Shellfish survey & SHELLS & -- & -- & NYSDEC, towns \\
\hline Shellfish tissue & SHELLT & -- & -- & NOAA \\
\hline Horseshoe crab survey and health & HSC & -- & -- & Universities \\
\hline Invasive flora & INVFL & -- & -- & $\begin{array}{l}\text { FWS, NPS, TNC, towns, Shinnecock Tribal } \\
\text { Nation, Audubon Society }\end{array}$ \\
\hline Invasive fuana & INVFU & -- & -- & FWS, NPS, towns \\
\hline Macroinvertibrate survey & MACRO & -- & -- & NYSDEC \\
\hline Wildlife survey & WILD & $\mathrm{FF}$ & -- & FWS, NPS, NYSDEC, Audubon Society \\
\hline
\end{tabular}


Table 1. Constituents collected or proposed for monitoring of water or ecological resources in the South Shore Estuary Reserve, New York.-Continued

[A constituent may be considered a trophic state indicator (TSI) and (or) a forcing function (FF) on the basis of descriptions provided in the introduction of the report. Constituent codes are abbreviations used to cross-reference tables in this report and for the filter function of the website. N, nitrogen; P, phosphorus; PAH, polycyclic aromatic hydrocarbon; VOC, volatile organic compound; lidar, light detection and ranging; SAV, submerged aquatic vegetation; TNC, The Nature Conservancy; USGS, U.S. Geological Survey; NYSDEC, New York State Department of Environmental Conservation; SoMAS, Stony Brook University School of Marine and Atmospheric Sciences; EPA, U.S. Environmental Protection Agency; NOAA, National Oceanic and Atmospheric Administration; Seatuck, Seatuck Environmental Association; SPLASH, Operation SPLASH; FWS, U.S. Fish and Wildlife Service; NPS, National Park Service; NWS, National Weather Service; NYSDOT, New York State Department of Transportation; --, not applicable]

\begin{tabular}{|c|c|c|c|c|}
\hline Constituent & $\begin{array}{l}\text { Constituent } \\
\text { code }\end{array}$ & $\begin{array}{l}\text { Trophic state } \\
\text { indicator tier/ } \\
\text { forcing functions }\end{array}$ & $\begin{array}{c}\text { Related biological } \\
\text { ecological indicators/ } \\
\text { sentinels } \\
\text { (if applicable) }\end{array}$ & $\begin{array}{l}\text { Synergy_organizations with current } \\
\text { or proposed monitoring }\end{array}$ \\
\hline \multicolumn{5}{|c|}{ Estuary } \\
\hline Surface elevation table & SET & -- & -- & NPS, USGS, FWS \\
\hline Bathymetry & BATHY & -- & -- & NOAA, SoMAS \\
\hline $\begin{array}{l}\text { Edge of wetlands (remote sensing/ } \\
\text { drone) }\end{array}$ & WETLAND & -- & -- & Town of Hempstead \\
\hline Particle size (bed sediment) & PART & FF & -- & SoMAS, USGS \\
\hline Sediment redistribution & SR & FF & -- & SoMAS \\
\hline Wave energy & WVE & -- & -- & -- \\
\hline Wave height & WVH & -- & -- & USGS \\
\hline \multicolumn{5}{|c|}{ Air } \\
\hline Precipitation & PRECIP & -- & -- & USGS, Town of Hempstead, SoMAS, NWS \\
\hline Air temperature & AT & -- & -- & USGS, Town of Hempstead, SoMAS, NWS \\
\hline Air quality & $\mathrm{AQ}$ & -- & -- & NWS \\
\hline $\begin{array}{l}\text { Weather (such as wind, sky, } \\
\text { humidity) }\end{array}$ & WEATHER & -- & -- & SoMAS \\
\hline \multicolumn{5}{|c|}{ Infrastructure } \\
\hline Land use & LU & FF & -- & Suffolk County, Nassau County \\
\hline Impervious cover & IMPCOV & -- & -- & -- \\
\hline Storm drain outfalls & SDO & -- & -- & Towns, NYSDOT, counties \\
\hline $\begin{array}{l}\text { Sewage treatment plant sewerline } \\
\text { and outfalls }\end{array}$ & STP & $\mathrm{FF}$ & -- & Counties \\
\hline Topography (aerial, lidar) & TOPO & -- & -- & NOAA, USGS \\
\hline Inundation & INUN & -- & -- & USGS, FEMA, EPA \\
\hline Photography & РHOTO & -- & -- & USGS, FWS, NPS, NOAA, SoMAS \\
\hline
\end{tabular}


have had a comprehensive management plan created to assess in detail the contributions to poor water quality within the watershed (table 2; appendix 3). In particular, waterbodies in the Reserve requiring the development of a TMDL for nitrogen include Hog Island Channel, Hempstead Lake, Hempstead Bay, Moriches Bay, Reynolds Channel, and Great South Bay. Furthermore, nitrogen-loading data necessary for groundwater flow, runoff, and atmospheric deposition models are not currently available on the scale needed for evaluating the entire Reserve. Additionally, recent studies from other parts of the country have implicated excessive nitrogen as contributing to the increased vulnerability of the salt marshes (vegetation and mass) of the region (New York State Department of Environmental Conservation, 2014b). Additional impairments to the ecology of the bays and tributaries include excess concentrations of pathogens (from wildlife excrement, leaky sewer lines, illicit discharges to storm sewers, and surface runoff) and of suspended sediment (suspended; from runoff), and aquatic toxicity (caused by low dissolved oxygen or harmful algae and bacteria). Although certain constituents can be measured in situ to directly or indirectly inform the extent of these impairments throughout the Reserve and provide the data necessary to understand cyclic (for example, diurnal with tidal exchange) and episodic (for example, during a precipitation event) changes, the number of sites are limited and the network of continuous monitoring could be enhanced with additional locations to improve spatial resolution and understand localized issues.

The rapid decline in shellfish populations in the early 1970s, a result of overharvesting, has contributed to declines in water quality (including harmful algal blooms) that hinder efforts to repopulate the bays with shellfish (Board of Trustees of the Town of Southampton, 2001; Town of Brookhaven, 2013). Efforts by the NYSDEC, The Nature Conservancy (TNC), the Shinnecock Tribal Nation, and the Towns of Islip, Hempstead, and Babylon, along with other organizations, are underway in controlled areas to restore oyster and clam populations throughout the Reserve. Furthermore, recent (2017) initiatives by the New York State (NYS) Governor's Office are providing funds and coordination to create shellfish sanctuary areas in Bellport Bay, Shinnecock Bay, Hempstead Bay, and South Oyster Bay to help improve water quality and bolster the economy (New York State Governor's Office, 2017). The goal of continued restoration efforts of natural vegetation along the shoreline, riparian zones, and bay bottom is to improve habitat for finfish and shellfish in the bays and enable their populations to thrive. The Alosa pseudoharengus (alewife), Mercenaria mercenaria (hard-shell clam), Mytilus edulis (blue mussel), Anguilla rostrata (American eel), and Limulus polyphemus (horseshoe crab) populations that are being monitored by State, academic, and nonprofit organizations can be used as bioindicators to assess improvements to water quality in the bays and tributaries (The Nature Conservancy, 2012). However, the health of these species is still affected by urbanization and physical barriers in spawning areas.
In 2007, the National Oceanic and Atmospheric Administration (NOAA) reported on the level of eutrophication in every estuary in the contiguous United States (Bricker and others, 2007). The South Shore Estuary Reserve (reported in entirety as "Great South Bay") was characterized by using the Assessment of Estuarine Trophic Status (ASSETS) rating system, which considers available data for dissolved oxygen, chlorophyll $a$, nutrient loading, algae (macroalgae and harmful or nuisance algae), aquatic vegetation, and water clarity to determine the overall eutrophication level within four distinct zones of the estuary (fresh, fresh tidal, mixed, and seawater). The overall eutrophication condition of the Reserve was rated at "moderate high" on the basis of data for chlorophyll $a$, dissolved oxygen, and nuisance algae — data on nutrient loading and subaquatic vegetation were not available for inclusion in the assessment.

Hurricane Sandy (October, 2012) sparked initiatives to review management plans, build resilient infrastructure, and revitalize wetlands on Long Island, particularly within the Reserve. The Governor's Office of Storm Recovery (GOSR) was created and charged with assessing human and ecological effects of the storm and how to best rebuild. To meet the objectives of understanding the effects of the storm, the New York Rising Community Reconstruction Program was established by GOSR - there are currently 41 New York Rising projects in the Reserve, including locations in the Village of Island Park, Valley Stream, Oceanside, and Babylon (GOSR, 2017). Following the storm, water quality in Hempstead Bay, specifically Reynolds Channel, was particularly poor because of the discharge of partially treated sewage from the Bay Park Sewage Treatment Plant (Kenward and others, 2013). As communities began to rebuild, Federal and local agencies, academics, and consulting firms collected data to help determine what changes occurred to water and sediment quality of the Reserve (Fischer and others, 2015; NOAA, 2012). The long-term effects of these discharges on the wetlands and bottom environment of the bays are unknown. However, the studies quantified chemical contaminants and modeled transport throughout the bays, and these data provide a reference point for future events and for efforts to reshape the sediment (dredging) and rebuild shoreline (improved infrastructure). Changes to the Reserve ecosystem are also addressed by modeling of sediment transport along the barrier islands (USGS, 2017a) and extensive studies of physical implications (tide changes, sediment movement) and chemical implications (water quality, flushing) of the breach remaining open at Old Inlet (Fire Island National Seashore) (Aretxabaleta and others, 2014; Flagg and others, 2013; multiple reports listed in Flagg and others, 2016).

\section{Current (2017) Management Topics}

Managing the resources of the Reserve is a shared responsibility. The bays and tributaries of the Reserve afford opportunities for commercial and recreational fishing and 
Table 2. Management plans for water or ecological resources in the South Shore Estuary Reserve, New York.

[Table 2 is a summary of management plans and other documents that present recommendations based on specific locations or resources; an expanded list of documents (including updates) is presented in appendix 3]

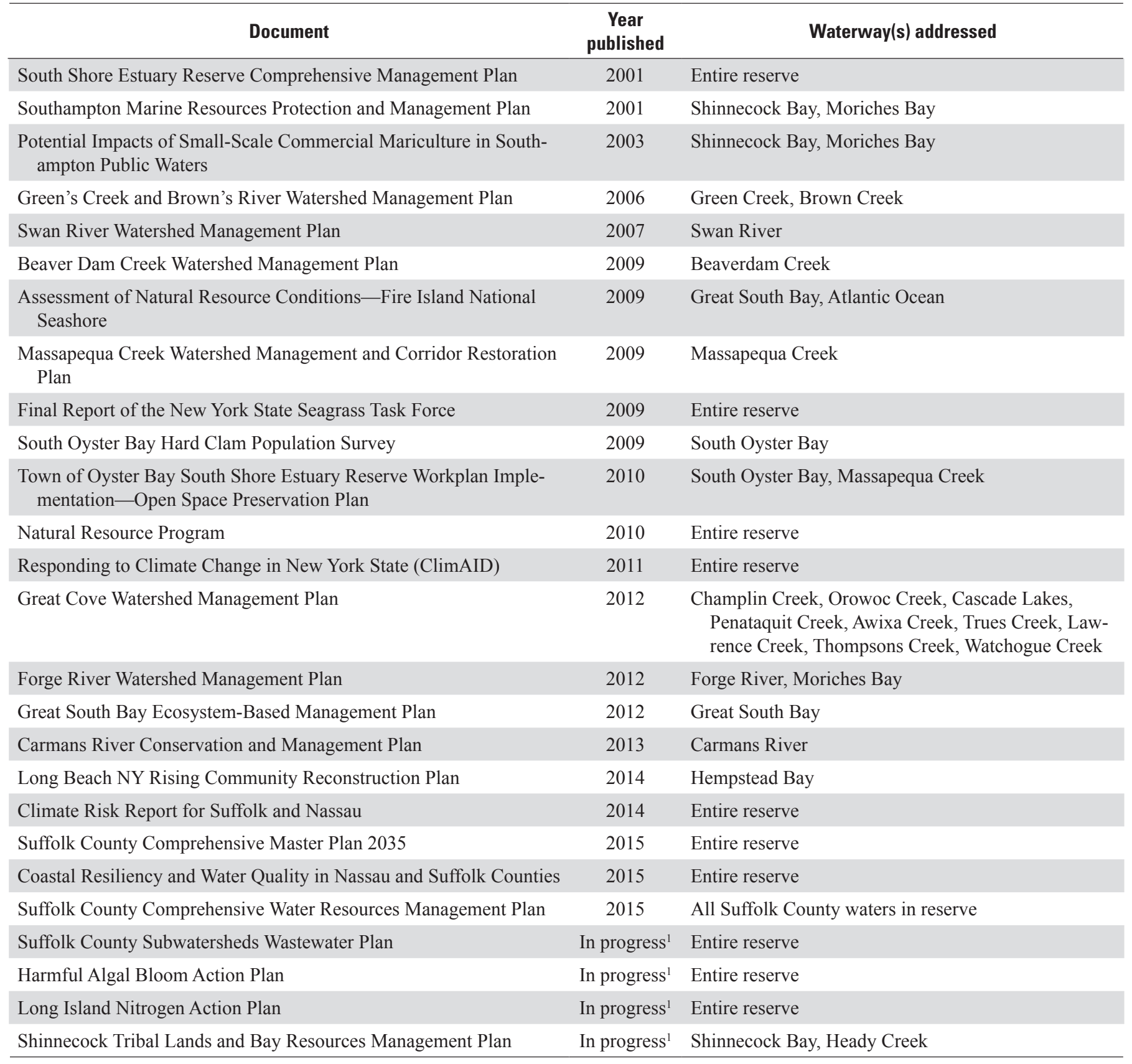

${ }^{1}$ In progress as of May 2017. 
public use (such as swimming), all of which are affected negatively by poor water quality. The following subsections summarize management topics related to water quality and environmental health within the Reserve. Issues identified by the PAC and stakeholders have been compiled from meeting minutes and are listed in table 3 . These issues are addressed in subsequent sections of this report, where stakeholder recommendations for filling data gaps and comments about general program development and coordination are presented.

\section{Eutrophication}

Nitrogen and phosphorus loading throughout Long Island has recently become the focus of several State and local efforts (NYSDEC, 2014b, 2017; Suffolk County Government, 2015) and has led to the creation of action and management plans aimed at reducing loading from point (sewage treatment plant and storm drain outfalls) and nonpoint (stormwater runoff, onsite wastewater treatment and disposal, and agriculture) sources. Major implications of excess nutrients, in particular nitrogen, include loss of critical habitats (aquatic vegetation such as eelgrass) and salt marshes, low dissolved oxygen and hypoxia, macroalgae blooms, toxic algal blooms, and loss or depletion of shellfisheries. A strong correlation has been shown to exist between nitrogen loading and population growth, with loading to the bays attributed mainly to groundwater affected by failing septic systems and antiquated cesspools (collectively, inadequate onsite wastewater treatment systems) and agricultural practices, atmospheric deposition, and effluent from wastewater treatment plants (Kinney and Valiela, 2011; Stinnette, 2014).

Groundwater loading of nitrogen to embayments presents a challenge to managers seeking to reduce nitrogen concentrations to the bays, especially in inland areas with onsite systems where groundwater can take decades to reach a tributary or seep through the bay bottom (Suffolk County Government, 2015). Two recent models show that groundwater contributes about 69 percent of the nitrogen load to Great South Bay (Kinney and Valiela, 2011) and 61 percent of the loads to Moriches and Shinnecock Bays (Stinnette, 2014). To provide a nitrogen budget for the Reserve, these modeled estimates need to be corroborated with historical data available from current monitoring programs and new studies of atmospheric, runoff-specific, and sediment dynamics of bay bottoms and the hyporheic zone of streams. An updated model of areas contributing to groundwater recharge is being developed by the USGS with the NYSDEC under the Long Island Nitrogen Action Plan (LINAP) and could provide the foundation for the loading models and decision support tools needed to help estimate the effects of changes from wastewater infrastructure upgrades, low-impact development, and implementation of new sanitary regulations. Current water-quality monitoring programs that analyze for nutrients are in place in the bays and select streams to provide a glimpse at the overall health of the estuary. However, to evaluate the benefits of implementing new practices, it would be necessary to coordinate existing water-quality monitoring programs and incorporate additional resources and tools.

\section{Managing Wastewater Infrastructure}

Wastewater infrastructure (including sewage treatment plants and onsite wastewater-treatment systems) in the lowlying areas of the Reserve spans the population gradient and has been tied directly to the water quality of the bays and tributaries (Monti and Scorca, 2003). The extent of wastewater management systems (that is, centralized sewage treatment plants and municipal separate storm sewer systems) within the Reserve, in general, correlates well with population density, with the western part being sewered and the eastern part largely unsewered. Inadequate onsite wastewater treatment systems are believed to contribute substantial nitrogen loading to the aquifer system (Stinnette, 2014), whereas the effects of implanting sewage treatment in higher density areas can be observed in historical groundwater and surface-water data (Monti and Scorca, 2003). Sewage treatment infrastructure in Nassau County and western Suffolk County is monitored as part of regulatory requirements (NYSDEC, 2016b). Monitoring to assess the immediate and gradual improvements expected from these changes is important to gaging ecosystem response to both (1) the shift from inadequate onsite wastewater treatment systems to centralized sewage treatment plants or onsite treatment (or the innovative alternative onsite wastewater treatment systems being tested by Suffolk County since 2015) and (2) upgrades to existing sewage treatment plants. In particular, organic and inorganic (organic nitrogen, nitrate, nitrite, ammonium) forms of nitrogen and suspended solids in waters adjacent to outfalls and in the shallow aquifer would exhibit the greatest changes over the short term.

Five major sewage infrastructure projects are proposed in Nassau and Suffolk Counties to improve resiliency and water quality.

- Reduce extensive nitrogen pollution to the Forge River and Great South Bay by constructing new sewage infrastructure on municipal property near the Brookhaven Calabro Airport.

- Reduce nitrogen and pathogen pollution in the Carlls River and Great South Bay by connecting parcels not currently sewered to the Bergen Point sewer system within the Southwest Sewer District.

- Reduce nitrogen pollution and pathogens in Connetquot River, Nicoll Bay, and Great South Bay by connecting parcels to the Bergen Point sewer system.

- Reduce nitrogen and pathogen pollution in Patchogue River and Great South Bay by connecting remaining parcels to the Patchogue sewer system within the Village of Patchogue Sewer District.

- Reduce nutrient pollution by expediting upgrades at the Bay Park Sewage Treatment Plant and installing a 
Table 3. Management issues identified by the Project Advisory Committee for the South Shore Estuary Reserve Coordinated Water Resources Monitoring Strategy.

[Abbreviations of the related management plan documents reference table 3-1. NYSDOS, New York State Department of State; Reserve, South Shore Estuary Reserve; STP, sewage treatment plant; FEMA, Federal Emergency Management Agency; NYSDEC, New York State Department of Environmental Conservation; SCDHS, Suffolk County Department of Health Services]

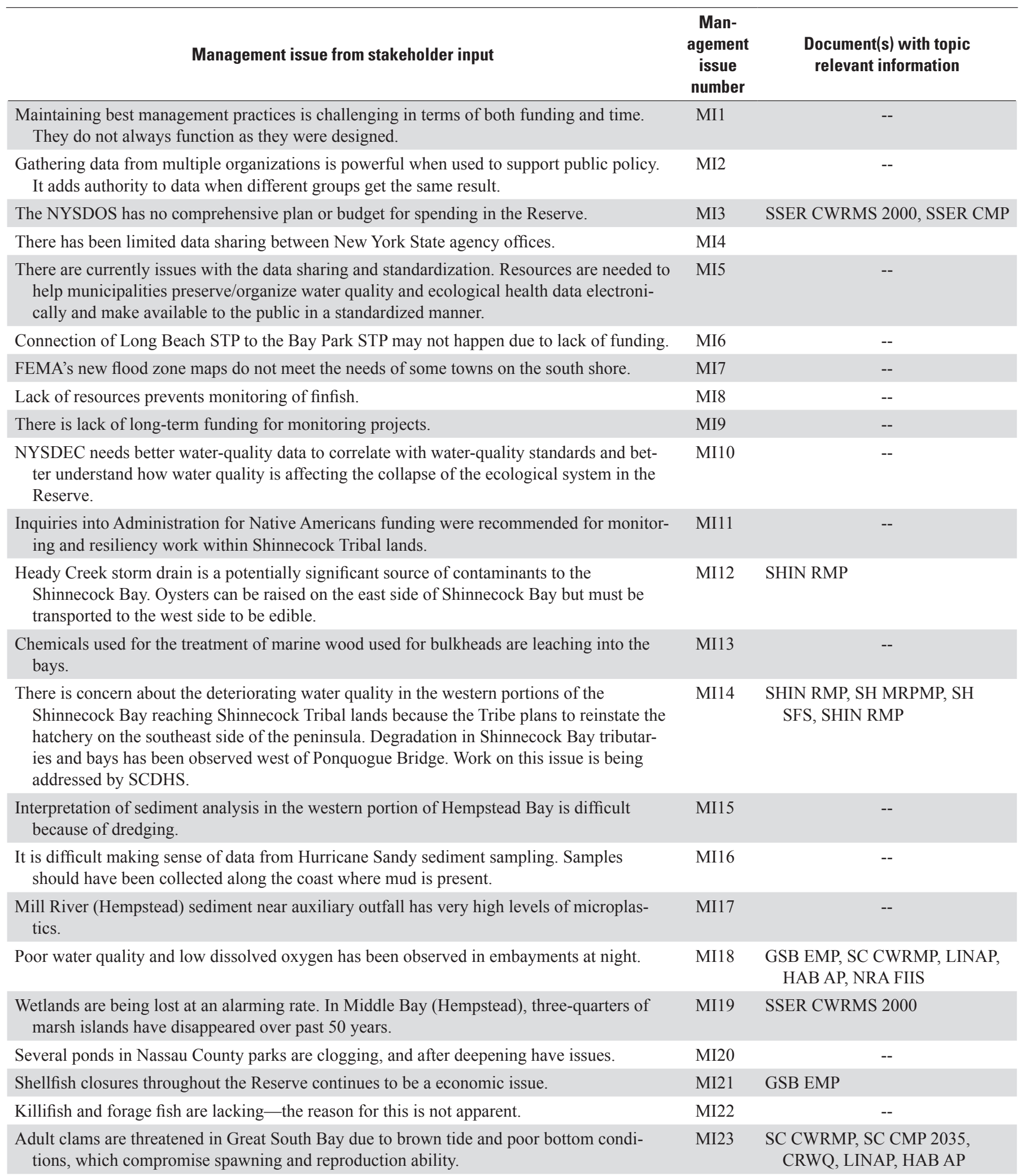


Table 3. Management issues identified by the Project Advisory Committee for the South Shore Estuary Reserve Coordinated Water Resources Monitoring Strategy.-Continued

[Abbreviations of the related management plan documents reference table 3-1. NYSDOS, New York State Department of State; Reserve, South Shore Estuary Reserve; STP, sewage treatment plant; FEMA, Federal Emergency Management Agency; NYSDEC, New York State Department of Environmental Conservation; SCDHS, Suffolk County Department of Health Services]

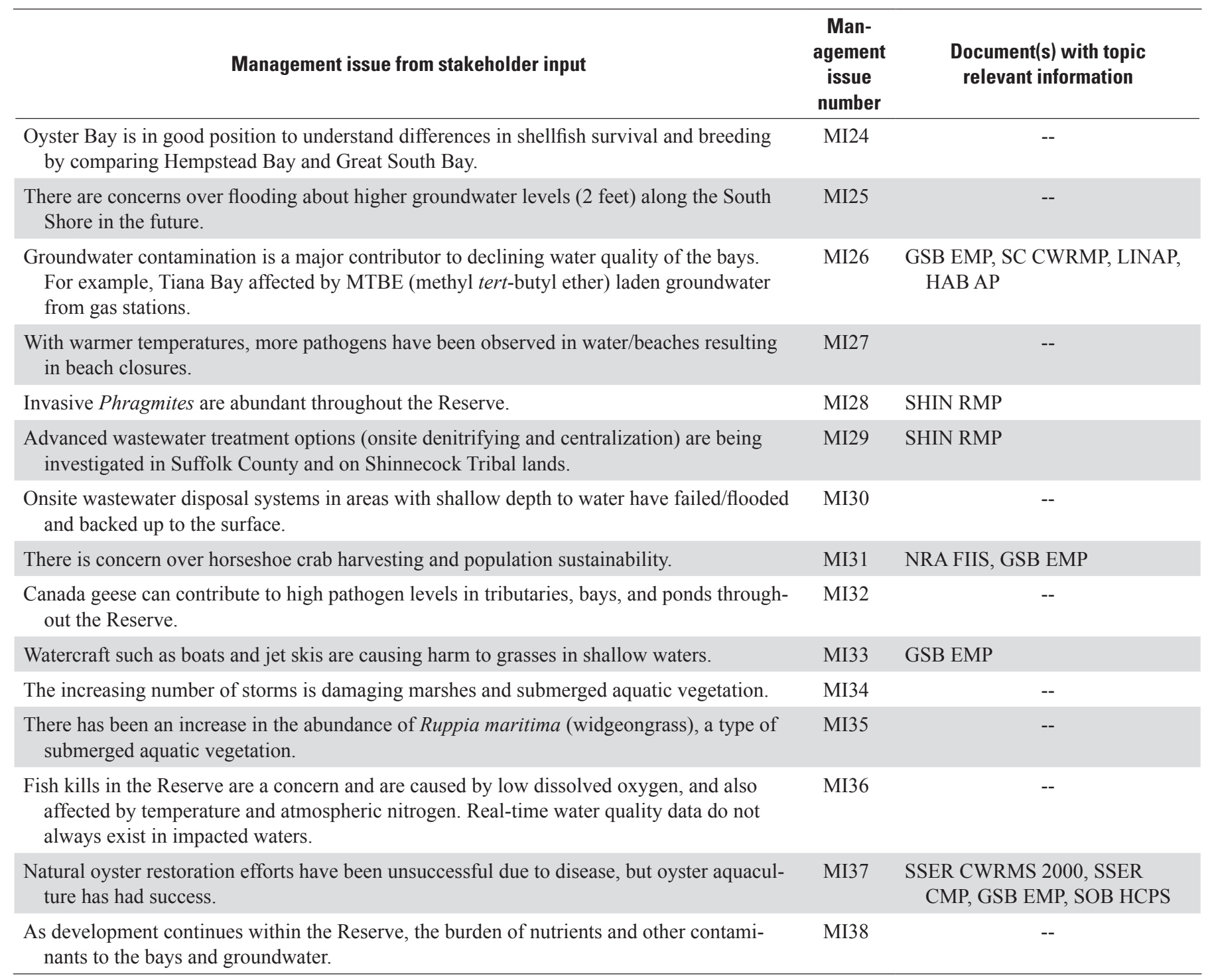


midstage nitrogen treatment system to improve water quality in the Hempstead Bay and protect extensive marsh islands, which serve as natural flood protection barriers for southern Nassau County (GOSR, 2014). Further reduction of nutrient loading to the Reserve is expected following the diversion of effluent from Bay Park Sewage Treatment Plant to Cedar Creek Water Pollution Control Plant (which discharges to the Atlantic Ocean) and the proposed conversion of Long Beach Sewage Treatment Plant to a pump station to transport wastewater to the Bay Park Sewage Treatment Plant.

The current water-quality monitoring program conducted by the Town of Hempstead and Nassau County serves as a baseline for changes in nutrient loading and how the western bays of the Reserve respond over time. There is some debate as to how altering the loading of nutrients to the system would affect the current ecological balance (John Tanacredi, Molloy College, written commun., 2016). Poor water quality in Hewlett and Brosewere Bays has been attributed, in part, to poor circulation and flushing (Swanson and others, 2013) and the Bay Park Sewage Treatment Plant and linked to increased Ulva growth throughout Hempstead Bay over the past decade. Some researchers suggest, however, that a sharp decrease in nitrogen to the bays could lead to marsh island loss - an issue exacerbated by motorboat traffic and continuous erosion by natural wind-driven waves (James Browne, Town of Hempstead Conservation and Waterways, oral commun., 2015).

Municipal separate storm sewer system (MS4) regulation requires towns to monitor the stormwater infrastructure to prevent contaminant discharge according to an approved stormwater management program. Water quality (constituents include suspended sediment, conductivity, nutrients, primary pollutants), discharge, and flow (of receiving waterbody) data are needed to make informed decisions about meeting management objectives and permit requirements, as well as to provide data for model input (NYSDEC, 2008). A 2009 American Recovery and Reinvestment Act grant was awarded by the NYSDEC to support stormwater management planning in over 100 communities in Nassau and Suffolk Counties, particularly in MS4-permitted systems that discharge to waters impaired by pathogens (NYSDEC, 2012).

\section{Pathogens}

Bacteria and viruses associated with sewage and wildlife excrement continue to affect public beaches and shellfishing in the Reserve. Indicator bacteria are used to determine whether waters are safe for recreation or fishing. Agencies responsible for sampling waters of the Reserve for indicator bacteria include the NYSDEC, the health departments of Nassau and Suffolk Counties, the National Park Service (NPS), and New York State Office of Parks, Recreation, and Historic Preservation. Total and fecal coliforms are used for determining closures of areas to shellfishing. Per U.S. Environmental Protection Agency (EPA) guidelines and recommendations made in the 2000 CWRMS, Enterococcus spp. (enterococci) are being used as a fecal indicator at marine bathing beaches because enterococci correlated better with the incidence of illness than coliforms (Boehm and Sassoubre, 2014). Elevated indicator bacteria concentrations at beaches and in shellfish areas following heavy precipitation continue to result in closures based on current data and predictions based on historical data. Automated public alerts, such as USGS Nowcast (Francy and others, 2013; USGS, 2016a), have been developed in other areas. These alert systems rely on real-time weather data and current and historical bacteria data collected by local health agencies. The data are ingested by the EPA Virtual Beach program (EPA, 2017b), and the resulting models are designed to forecast closures because of high pathogen concentrations. This model performs well as long as an active and rigorous water-quality sampling program is in place.

Techniques for identifying sources of pathogens (for example, stormwater runoff, direct loading from wildlife, and the influence of inadequate onsite wastewater treatment), such as microbial source tracking, help inform load-reduction initiatives and TMDL regulation. Advanced methods that use DNA and RNA sequencing could potentially differentiate contributing species and types of bacteria that are pathogenic (Griffin and others, 2000; Corsi and others, 2016). With these methods and with data on the appropriate water-quality constituents (nutrients, metals, natural and anthropogenic organic compounds), resource managers can work towards implementing infrastructure upgrades and wildlife controls and updating regulations on effluent and discharges.

\section{Total Maximum Daily Loads}

A TMDL for impaired waterbodies provides resource managers with a planning tool and potential starting point for restoration or protection activities with the ultimate goal of attaining or maintaining water-quality standards (EPA, 2017a). Developing a TMDL for nitrogen, phosphorus, pathogens, or other constituents requires a considerable investment of funds and personnel to compile existing data and collect any additional data needed to model and enforce recommended changes in the loading. Leveraging and standardizing existing data collection efforts to generate data necessary for a TMDL, including source assessment and fate and transport studies, could help offset costs. Other environmental and human factors necessary to assess when developing a TMDL include land-use designation and sewerage, precipitation, and hydrologic properties of the groundwater and surface waters.

The sources and concentrations of contaminants to some of the waterbodies of the Reserve have been modeled or estimated for nitrogen, and implementing a strategy (even without a TMDL) for the reduction of total loading to the bays throughout Long Island is the goal of the Long Island Nitrogen Action Plan initiated by the NYSDEC in cooperation with Nassau and Suffolk Counties. In the western bays of the Reserve, researchers at the Stony Brook University School of Marine and Atmospheric Sciences (SoMAS) are working with 
the NYSDEC and the New York State Department of State to compile a dataset to develop a TMDL for nitrogen (including data collected by the Town of Hempstead, Nassau County, USGS, and SoMAS). The Nitrogen Load Model used for Great South Bay (Kinney and Valiela, 2011) and the eastern bays of the Reserve (Stinnette, 2014) would also allow for comparison to the other parts of the Reserve already assessed. Monitoring within subwatersheds would support and validate the model and refine data inputs for nitrogen, phosphorus, pathogens, sediment, and other contaminants identified on the NYSDEC 303(d) list (Lloyd, 2014).

\section{Harmful Algal Blooms}

Harmful algal blooms (HABs) were included as a reason for impairment on the NYSDEC 303(d) list for Great South Bay, Moriches Bay, Quantuck Bay, and Shinnecock Bay starting in 2010. Since the CWRMS was drafted in 2000, the Reserve has experienced an increase in the frequency of Aureococcus anophagefferens (brown tide), which first appeared on Long Island in 1985, in the Great South Bay and eastern bays of the Reserve (Suffolk County Government, 2016). Identification of Alexandrium fundyense (red tide) and Cochlodinium polykrikoides (rust tide) also occurred for the first time in 2002 and 2004, respectively, and has recurred in subsequent years (Branca and Focazio, 2009). Though blooms of algae associated with brown, red, or rust tides can harm shellfish, toxins produced by red tide are toxic to finfish and those from rust tide are toxic to humans.

The issue of harmful algal blooms is international as they affect fresh and marine waters and lead to closures of shellfisheries, with economic implications for fishermen, tourism, and recreation, as well as harming wildlife. Efforts are underway to understand the causes and factors driving these blooms in the Reserve and throughout the world. Factors currently shown to influence the proliferation of HABs in estuaries include nitrogen and phosphorus loading (from groundwater affected by inadequate onsite wastewater treatment systems, atmospheric deposition, and stormwater runoff), poor circulation, and micronutrient concentrations (Paerl, 1997; Heisler and others, 2008; Gobler and others, 2012; HattenrathLehmann and others, 2015). The improvements to water quality and decline in brown tide observed in the eastern Great South Bay have been attributed to the opening of Old Inlet breach on Fire Island following landfall of Hurricane Sandy. The type of toxins produced by each HAB and the extent to which a bloom occurs are also being studied from samples collected in the Reserve and elsewhere on Long Island (Gobler and others, 2012).

Experts from around the region assembled for the Long Island HAB working group (led by New York Sea Grant and Suffolk County Department of Health Services [SCDHS]) to create the Suffolk County Harmful Algae Bloom Action Plan (Wise, 2017) for the Reserve, Peconic Estuary, Long Island Sound, and inland fresh waterbodies of Long Island. It takes a coordinated, multidisciplinary monitoring and research effort to address the HABs issue. One example of Federal, State, and local agencies together addressing the HABs problem in their community is in Tampa Bay, Florida. Starting around 1970, the population of the Tampa Bay watershed increased to the point where the human effect on the Bay led to major waterquality impairments. Through a concerted effort and continued monitoring and response (that is, infrastructure improvements, runoff controls, and community outreach), the community rehabilitated the waters in the Tampa Bay watershed (Tampa Bay Estuary Program, 2013). An extensive water-quality monitoring program is still in place to ensure continued improvement and compliance with regulation throughout the bay area.

\section{Wetland Loss}

Resource and emergency managers are increasingly recognizing the importance of wetlands (such as shoreline and island marshes) in mitigating infrastructure damage and shoreline erosion from extreme weather events in the wake of Hurricane Sandy (Wagner and others, 2014). Marshes in particular provide a buffer to storm surges and wave attenuation (Möller and others, 2014; Stark and others, 2015). The Wetlands Stewardship Strategy introduced by Suffolk County is expected to provide the basis for increased Federal and State aid, which will allow the county to rehabilitate more than 2,500 acres of damaged wetlands, thereby restoring habitat and improving shoreline resiliency (Leuzzi, 2015). Other marsh restoration projects funded by National Fish and Wildlife Foundation grants are underway throughout the Reserve to assist Suffolk and Nassau Counties, Cornell Cooperative Extension, the Shinnecock Tribe, the towns and villages, other government and nonprofit organizations, and academia to engineer and rebuild shorelines to serve as habitat and natural buffer against wave energy.

The NYSDEC (New York State Department of Environmental Conservation, 2014; Cameron Engineering \& Associates, LLP., 2015), the Town of Hempstead Department of Conservation and Waterways, and the Suffolk County Department of Public Works actively monitor changes in wetland loss by using aerial imagery and geographic information systems (GISs) to track the progress of efforts to restore marshes along the shore and in the bays. Recognized influences on wetlands include nutrient loading, boat traffic, and shoreline changes (such as bulkheading). In coastal areas, high nitrogen loading has been implicated as a driver in marsh loss (Deegan and others, 2007) because the root network of wetland grasses may grow shallow and thus would not be able to anchor and protect the sediment from erosion. This may mean that efforts to construct wetlands and improve resiliency could be negatively influenced by the continuous nutrient loading to the bays of the Reserve from groundwater seepage and other contributors of nitrogen. Other drivers of wetland loss include sea-level rise and increased wave energy from watercraft wakes. Therefore, in monitoring wetland loss, it is important to continue assessing water quality, develop loading estimates, and study vegetation density and shoot-to-root ratios in and around wetlands 
as restoration efforts (and infrastructure changes that alter nitrogen loadings) are implemented.

\section{Decline in Fisheries}

Shellfish populations in the Reserve continue to decline, though efforts to revitalize populations through hatcheries, selective farming, and habitat restoration (The Nature Conservancy, 2012) are ongoing. Improved water quality is expected if filtering bivalves become more abundant, but improved water quality is also needed to ensure successful restoration. Currently, monitoring data are collected near the surface by Suffolk County in Great South Bay and by the Town of Hempstead in Hempstead Bay, and monitoring of bottom temperature, $\mathrm{pH}$, and dissolved oxygen is generally limited to shellfish areas.

Poor water quality has been implicated in the recent fish kills in the Peconic Estuary and Long Island Sound. There is concern that the Reserve will experience fish kills on a larger scale if water quality is not improved. Further complicating the issue is the way in which some fish species (such as Brevoortia tyrannus [menhaden]) move and feed, which can result in a large number being present in waters with insufficient flow or mixing to sustain dissolved oxygen concentrations necessary for survival. During the large fish kill in the Peconic Estuary, near the mouth of the Peconic River in spring 2015, the USGS Peconic River at County Road 105 waterquality monitoring station (station 01304562) reported a dissolved oxygen concentration decrease to near zero. However, at the same time, chlorophyll concentrations were elevated, which indicated high algae concentrations. These data raised the question of whether the fish suffocated or were poisoned by HABs. Therefore continuous data, along with toxicological studies, are necessary to better understand the causes of, and how to limit, major fish kills.

\section{Aquatic Vegetation Restoration}

Loss of nearshore (for example, Spartina) and submerged vegetation (for example, eelgrass) has resulted from the decline of water quality and the introduction of invasive species to the Reserve, particularly in the eastern bays (NYSDEC, 2004; New York State Seagrass Taskforce, 2009). Submerged aquatic vegetation (SAV) provide critical habitat for finfish and shellfish to feed, reproduce, and avoid predation while increasing dissolved oxygen concentrations in bottom waters. A Reserve-wide survey of seagrass in 2002 showed eelgrass had declined considerably; the decline was attributed in part to poor water clarity that prevented sunlight from reaching the bottom (New York State Seagrass Taskforce, 2009). Subsequent surveys by SoMAS and Cornell Cooperative Extension in the Great South Bay and eastern bays of the Reserve have also been conducted on a local scale. Water-quality constituents critical to revitalizing submerged vegetation include light penetration (turbidity), bottom water temperature, and $\mathrm{pH}$.

\section{Climate Change and Resiliency}

In 2007, the New York State Legislature created the Sea Level Rise Task Force and charged it with preparing a report that addresses issues related to climate change, sea-level rise, and ocean acidification. Led by the NYSDEC, the Task Force included a diverse membership of representatives from State and local government agencies, nongovernmental organizations, and affected communities. Their work presents recommendations for an action plan to protect coastal communities and natural resources from rising sea levels (New York State Sea Level Rise Task Force, 2010). The NYSDEC continues to evaluate potential effects of climate change through reports and updates to ClimAID (NYSDEC, 2014c). Following Hurricane Sandy, this effort was renewed and new initiatives were proposed. Upgrades to wastewater infrastructure (that is, sewer systems and stormwater systems) within the Federal Emergency Management Agency (FEMA) category 1 flood zones are underway at an accelerated rate with help from Federal and State grants. Funds are also being provided to help rebuild and harden coastal wetlands to provide a natural barrier for wave attenuation and ecosystem services (New York State Sea Level Rise Task Force, 2010).

The Community Risk and Resiliency Act (NYS bill A06558/S06617-B) was developed to provide guidance for NYS on predicted sea-level rise, storm surge and flooding in facility siting, recommendations for permitting and funding, State Smart Growth Public Infrastructure Policy Act criteria (ENV §6-0107), modeling of local laws concerning climate risk, and guidance on natural resiliency measures (NYSDEC, 2014a). FEMA produced the State Mitigation Plan, effective in March 2016, to demonstrate commitment to reducing risks from national hazards and serve as a guide for decision makers (FEMA, 2015).

In addition to sea-level rise, climate models predict coastal storms that are greater in intensity, similar to Hurricane Irene and Hurricane Sandy (and the nor'easters that followed), in the future. How to protect communities, critical infrastructure, and ecological habitat is a challenge facing all levels of government. In recent years, priority has been placed on building resiliency, with a focus on sustainability. The storm surge brought by Hurricane Sandy caused widespread damage to homes, bulkheads, piers, and wastewater-treatment infrastructure. While tidal wetlands and marsh islands in the bays have the capacity to lessen the effect of storm surge, wetland loss in the western bays of the Reserve has been documented (NYSDEC, n.d.[b]; Cameron Engineering \& Associates, LLP., 2015). This wetland loss makes homes along the shore more susceptible to future damage, particularly in areas now included in the Federal Emergency Management Agency's revised flood map (https://msc.fema.gov/portal/).

Among the long-lasting effects of Hurricane Sandy is the breach within the boundaries of Fire Island National Seashore (NPS, 2017). Old Inlet is within the Otis Pike Fire Island High Dune Wilderness. Two other breaches formed in Smith Point County Park and east of Moriches Inlet but were closed 
soon after the storm by the U.S. Army Corps of Engineers (USACE). The effects of the breach on ecological, biological, and physical constituents are not completely understood, though improved water quality in the Bellport Bay and surrounding waters may allow the ecosystem to recover from decades of poor flushing and vegetation loss (Flagg and others, variously dated). The USGS (2016b), NPS, SoMAS, and Cornell Cooperative Extension continue to monitor sediment transport, velocity of currents, and changes in basic waterquality constituents of the bays and capitalize on the potential for restoring eelgrass and shellfish to the area.

Extreme weather events are expected to increase in the region during the coming years because of climate change (Rosenzweig and others, 2011). Improving resiliency in the coastal communities of the Reserve requires assessing the ability for ecosystem and infrastructure to respond to changing environmental conditions (including sea-level rise) and rebound quickly after a storm. Agencies responsible for protecting the coastal communities are recognizing the importance of investing in adaptive measures that can reduce vulnerability and risk to extreme events (AKRF Inc., 2015; GOSR, 2017). Studies and models have been implemented to collect hydrologic data to better predict the intensity of the next storm on the coastal beaches, wetlands, and communities (USGS, 2014; NOAA, 2014). Furthermore, regional studies from Cape Cod (Cape Cod Commission, 2013), Chesapeake Bay (Lyerly and others, 2014), and Puget Sound (Puget Sound Partnership, 2012) emphasize the importance of an ecosystembased monitoring strategy that can identify areas of concern and provide input for refining models aimed at assessing changes in wastewater infrastructure. Linking infrastructure vulnerability to ecological data could also help in assessing the risk to habitat and wildlife populations (by maintaining and expanding inventories such as the Park Species List created by the NPS (2016) when rebuilding or creating coastal buffer wetlands (through State and local land-buying programs) to protect against a rising sea level.

Critical to supporting models and resiliency efforts is the continued monitoring of constituents to gage climate change and the sentinel species that are affected. Necessary constituents being collected for long-term tracking of climate change and sea-level rise are water temperature, salinity, $\mathrm{pH}$, water level, and chlorophyll concentrations. Ancillary data include nutrient concentrations, precipitation quantities, and air temperature data. Sentinel species in the Reserve that provide insight into changes in ecosystem health (from climate change or otherwise) include mussels and hard-shell clams ( $\mathrm{pH}$, temp), horseshoe crabs ( $\mathrm{pH}$, temp, salinity), eelgrass ( $\mathrm{pH}$, temp, water level), and wetland and marsh island grasses (nutrients, water level, salinity).

\section{Forcing Functions}

Much of the research, comments, and discussion presented in chapter 3 of the 2000 CWRMS regarding factors that ultimately contribute to the water quality and ecological health of the Reserve is still valid today (Ecologic LLC, 2000). The forcing functions, defined as "physical, chemical, biological, and human-induced factors which play a major role in determining water quality" (Ecologic LLC, 2000), were explained in the context of the body of knowledge and model predictions available at the time. An update is presented here with new information based on recent studies and events.

Many of the physical factors remain the same as in the 2000 CWRMS; however, the following updates apply:

1. Circulation and water quality have changed around the Old Inlet breach - initial data suggests water quality in Bellport Bay has improved with the increased flushing (Flagg, 2013; Brown, 2013).

2. Major coastal storms caused substantial bed-sediment redistribution - scouring and deposition - to an extent not quantified (Hydroqual, 2013; Swanson and others, 2013).

3. Inlets and tributaries of the Reserve have been dredged by Suffolk County and USACE to maintain navigation, and the dredging has altered circulation and sediment transport into and out of the bays and tributaries.

4. Flow models in Hempstead Bay indicate flow restrictions in Hewlett and Brosewere Bays (Swanson and others, 2013; Hydroqual, 2013), which have been attributed to poor water and sediment quality (Fischer and others, 2015).

5. Recent studies of submarine groundwater discharge to Great South Bay (from tributaries and across the bay floor) using direct-seepage measurements and radioisotopes estimate a groundwater discharge of around 3.5-4.7 $\times 10^{9}$ liters per day (Beck and others, 2007); groundwater discharge estimates have not been calculated for Hempstead Bay or the eastern bays of the Reserve.

6. Model estimates of groundwater recharge areas are available (CDM, 2003; updated in 2009).

7. Mean sea level rose 4.35 millimeters per year over 15 years at Bergen Point, New York, by 2016 (NOAA, 2016).

8. Average precipitation in the area is currently 120 centimeters per year, though this value is projected to increase because of climate change-precipitation rates across New York State could increase by approximately $1-8$ percent by $2020,3-12$ percent by 2050 , and 4-15 percent by 2080 (Horton and others, 2014; for updates see New York State Energy Research and Development Authority, 2014).

Many of the chemical factors remain the same as in the 2000 CWRMS; however, the following updates apply: 
1. Dissolved oxygen concentrations in bottom waters of the Great South Bay south of Connetquot River have been found to be hypoxic beyond typical diurnal cycling in some areas by The Nature Conservancy and SoMAS; marsh ditches experience anoxic conditions at night.

2. Nitrogen loading - total nitrogen estimates:

A. Great South Bay - total nitrogen: 50 percent wastewater origin, 16 percent atmospheric deposition on land (indirect), 26 percent atmospheric deposition to the bay (direct), and 7 percent use of fertilizer on land (Kinney and Valiela, 2011)

B. Eastern bays - total nitrogen: 65 percent wastewater, 20 percent fertilizer, and 15 percent atmospheric deposition (Stinnette, 2014)

C. Western bays - dissolved nitrogen: 79.4 percent of dissolved nitrogen from sewage treatments plants at Bay Park and Long Beach (http://www.unitedwaterlongisland.com/about-the-western-bays/)

Many of the biological factors remain the same as in the 2000 CWRMS; however, the following updates apply:

1. Harmful algal blooms in the Reserve have increased in frequency and the species type. (Gobler and others, 2008; Suffolk County Government, 2016).

A. Aureococcus anophagefferens (brown tide) blooms were first documented in the Great South Bay in 1985 and have since appeared with varying degrees of concentration and at varied locations throughout the Reserve, with large blooms in 2008 and 2013.

B. Cochlodinium polykrikoides (rust tide) blooms have been documented in Shinnecock Bay since 2004.

C. Alexandrium fundyense (red tide) blooms have been recorded in Shinnecock Bay in 2002, 2008, 2009, and 2012, though closure was only necessary 1 year; ingestion of shellfish harvested from bloom waters potentially affects human health.

D. Cyanobacteria (also known as blue-green algae) affect marine and freshwater environments; nearly annual reports of occurrence in Lake Agawam and Mill Pond in Southampton.

2. Eelgrass survey estimated coverage - aerial photographs taken in 2002 revealed about 20,015 acres of the Reserve currently support seagrass, of which 14,744 acres are in Great South Bay (New York State Seagrass Task Force, 2009). Continued updates to SAV surveys are necessary for the accurate assessment of seagrass growth patterns (that is, losses and gains).

3. Shellfish populations in the Reserve are low despite restoration efforts (such as expanding the number of hatcheries in the Reserve and closures of areas to shell- fishing) and public outreach, which have been underway for over a decade with the hopes of restoring pre-1970s conditions.

4. Recent management plans are addressing dams and other physical structures that prevent fish from moving upstream - efforts are underway to remove impediments or construct fish ladders on several tributaries (Carmans River [Suffolk County Government, 2014] and Massapequa Creek) as a means of restoring the natural ecology within the watershed.

Many of the human-induced factors remain the same as in the 2000 CWRMS; however, the following updates apply:

1. Total population of the six towns that are included in the Reserve (Hempstead, Oyster Bay, Babylon, Islip, Brookhaven, Southampton) increased about 3.5 percent over the past 15 years. The population was approximately 2.12 million people in 2002, 2.18 million in 2010, and 2.20 million in 2014. (U.S. Census Bureau, 2014). The population that lies within the boundaries of the Reserve (fig. 1) increased 1.1 percent between 2000 and 2010 based on block-level U.S. Census data (Manson and others, 2017). The percent change has been calculated for each town.
A. Hempstead decreased by 1.7 percent.
B. Oyster Bay decreased by 4.2 percent.
C. Babylon increased by 0.6 percent.
D. Islip increased by 2.7 percent.
E. Brookhaven increased by 9.0 percent.
F. Southampton increased by 5.1 percent.

2. In addition to what is listed in the 2000 CWRMS regarding groundwater contributions, the effects of increasing pumping to meet demand of an increasing population are being evaluated by water purveyors and government agencies. Increases in pumping can result in the lateral and vertical transport of contaminants introduced at the surface (for example, oil spills) or subsurface (for example, cesspool leachate), effectively transporting younger water deeper into the aquifers (Misut, 2011; EPA, 2015). Greater pump rates near the coast can result in saltwater intrusion in the aquifers (Barlow, 2003; USGS, 2016c) and potentially reduce the supply of freshwater to streams through base flow (Barlow and Leake, 2012).

\section{Trophic State Indicators}

Eutrophication of a waterbody is caused, in part, by human influences on a watershed. Though natural eutrophication occurs, the degraded water quality of the Reserve is mainly a result of the excess nutrient loading and other factors 


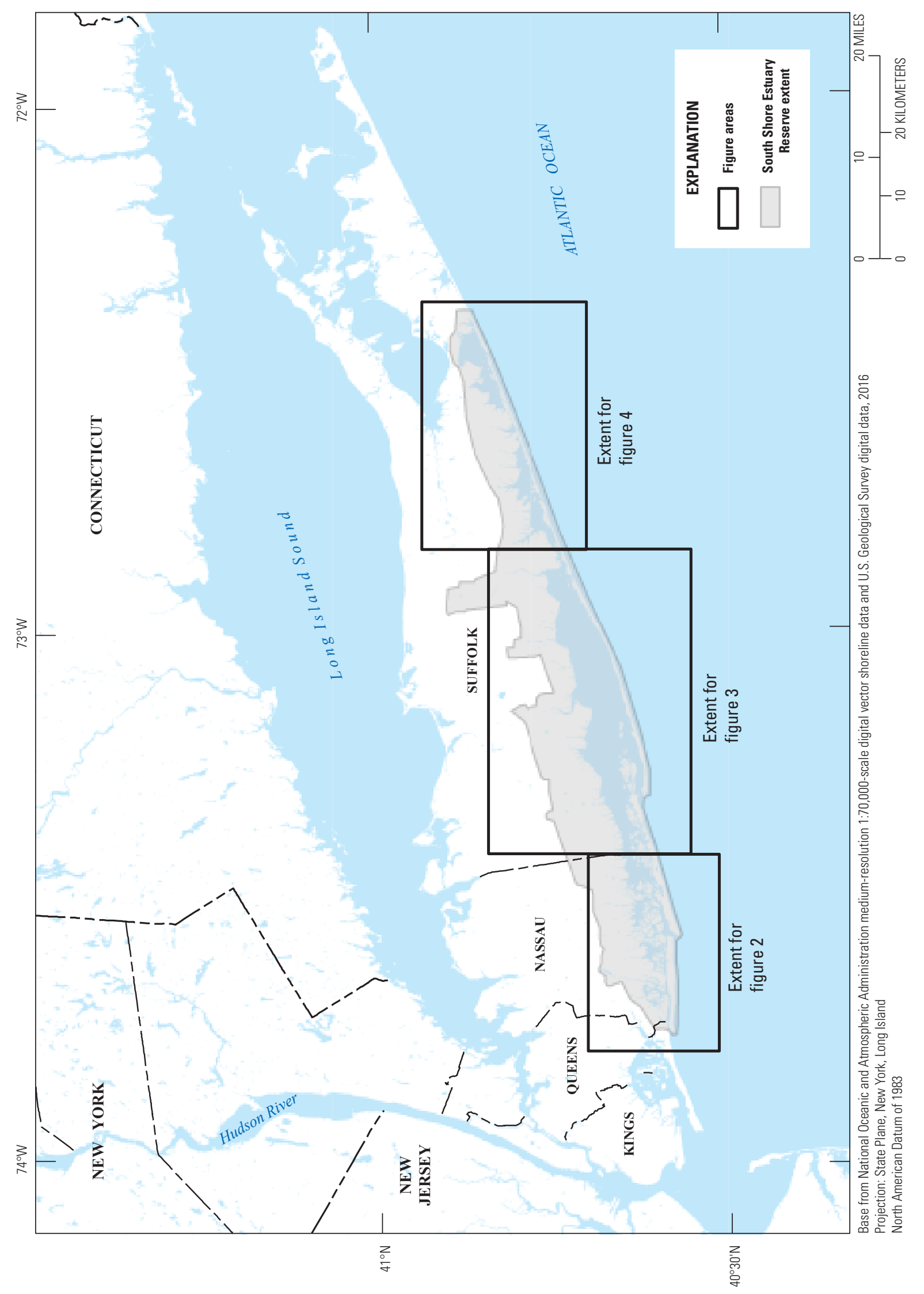

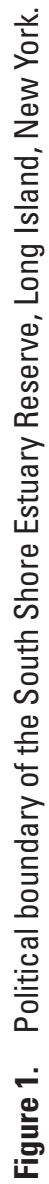


listed in the previous section. Over the past decade, indicators have been developed by the National Oceanic and Atmospheric Administration to readily assess the conditions of a waterbody by using inputs for primary and secondary indicators (Bricker and others, 2007). The waters are then assigned a rating, which can be used to help inform the public about why the ecosystem is affected and what would need to change in order for conditions to improve. The following indicators are used:

- Plankton - discrete samples for characterizations (phytoplankton versus zooplankton) and HABs

- Macroalgae - survey data

- Dissolved oxygen — continuous and discrete sampling

- Nutrient — nitrogen and phosphorus — loading values (based on supporting sample data)

- Water clarity and turbidity-continuous and discrete sampling

These indicators require data to be monitored consistently with proper quality assurance and over an adequate spatial distribution based on salinity gradients and waterbody features. The assessment also requires planning for the collection of related information, including land-use information, drainage areas, and elevation characteristics. Continued monitoring for the trophic state indicators (TSIs) could help establish trends that can be used to provide updates to the community as infrastructure, resiliency, and stormwater best management practices (BMPs) that include green infrastructure are implemented.

Using a set of criteria similar to the TSIs, the University of Maryland developed metrics by which estuaries could be reported in estuary report cards (Williams and others, 2009). Examples of these report cards have been created for watersheds of the Long Island Sound (University of Maryland Center for Environmental Science, 2015b) and the Chesapeake Bay (University of Maryland Center for Environmental Science, 2015a). By following the guidance in the "Sampling and data analysis protocols for Mid-Atlantic tidal tributary indicators" (EcoCheck, 2011), the three Reserve regions - western bays (Hempstead and South Oyster Bays), Great South Bay, and eastern bays (Moriches, Quantuck, and Shinnecock Bays) - could be divided into sections based on salinity gradient from start-of-flow through the watershed to the bays. It is likely that such a report card would result in low grades (on the scale A-D or F) for all three regions because of overall high levels of nutrient loading, documented areas of hypoxia, increased harmful algal blooms in the Great South Bay and eastern bays, and high amounts of Ulva in the western bays. A similar approach is used by the Gobler Laboratory of SoMAS to provide a water quality index that provides a weekly status of the waters around Long Island (News12, 2016) by using real-time water-quality monitoring data and grab samples collected for harmful algae colony counts. Incorporating loading estimates and available data on SAV would allow for the creation of a comprehensive report card for the Reserve and would be a useful tool for community outreach and citizen science engagement.

\section{Low-Impact Development and Best Management Practices}

Low-impact development, including green infrastructure (EPA, 2017c), and nonpoint or stormwater BMP implementation across Long Island generally occurs as individual projects on a small scale within a limited recharge zone (for example, storm drain inserts or roadway bioswales). Resources for proper design and implementation of stormwater management have been developed by the NYSDEC (NYSDEC, 2015; http://www.dec.ny.gov/chemical/96777.html), and effective monitoring before and after implementation is important to understanding successful implementation. Although results from a project can be used to support BMP use in other areas, little coordination is apparent at this stage. Small-scale projects are not likely to change the overall health of the Reserve ecosystem; however, monitoring the water and infrastructure function of these systems before and after project implementation is key to determining their overall contributions to the Reserve. Data and information about BMPs being used throughout the world can be found at the International Stormwater Best Management Practices Database website (http://www.bmpdatabase.org/index.htm).

Currently (2017), BMP projects have been established in the following areas: Nassau County recharge basins, though a shortage of resources does not allow for upkeep of the sediment traps and oil filters; storm drain inserts in the Village of Freeport; and bioswales along the roadways of Cedar Creek County Park within the Cedar Creek Water Pollution Control Plant. Although grants available from the EPA and other sources typically cover the cost of planning, construction, and limited maintenance, water and ecological monitoring and long-term maintenance are often not in place, in which case efficacy cannot be established over time. Further, water-quality and ecological-health monitoring of BMPs in other regions can be used as examples for the monitoring in the Reserve. Two examples of regional programs can be found in the Great Lakes and the Chesapeake Bay:

- Great Lakes

- The Great Lakes Coastal Resilience has cataloged initiatives and guidance for developing and monitoring based on issues and infrastructure type (Great Lakes Coastal Resilience, 2013).

- The Great Lakes Restoration Initiative is a partnership among 16 Federal agencies aimed at accelerating the revitalization of the Great Lakes. Under this program, the EPA and USGS develop monitoring programs in collaboration with States and municipalities and implement citywide BMP and green infrastructure projects (Great Lakes Restoration Initiative, 2016). 
- Chesapeake Bay

- The Chesapeake Bay Program has developed guidance that includes considerations across jurisdictional boundaries (in the case of the Reserve, towns and counties) for BMP implementation and monitoring in urban, agricultural, and mixed-use watersheds (Chesapeake Bay Program, 2012).

One strategy that has shown to be effective (with proper guidance and protocols) for monitoring basic constituents is coordination with community volunteers participating in citizen science (such as school or Boy and Girl Scout groups in the A Day in the Life program [http://www.portaltodiscovery. org/aday/about.htm]).

\section{Citizen Science}

Volunteer monitoring programs provide not only data important for indicating areas of potential concern but also an educational experience for those involved. Citizen science can be used to cover data gaps of basic water-quality constituents (for example, dissolved oxygen monitoring along a tributary with a declining fish population) and conduct surveys (for example, identifying storm drains that could be effective sites for green infrastructure) when Federal, State, and (or) local government resources are limited or monitoring frequencies are inadequate for answering specific questions about the waters. The goals of a citizen monitoring program - to provide a basic understanding of water quality in a bay or directly inform decisions related to waterbody impairment listingsare important considerations when choosing protocols and methods for collecting data. Field methods, quality assurance, and resources used by other groups for estuaries across Long Island and throughout the country can be transferable. There are a number of guides for citizen science monitoring, and it is important that an approved quality assurance project plan (QAPP) is followed for data to be considered for use in decision making by other organizations. Acknowledging the work of all groups collecting and providing data, regardless of quality, is necessary for encouraging and promoting citizen science in the Reserve.

\section{Synergy Among Existing Management and Action Plans}

Over the last 15 years, more than 30 management and action plans evaluating the ecological resources of the Reserve have been completed or are under development. These plans outline different issues currently facing areas of the Reserve, propose who can address the issues and how, and address areas ranging in scope from a single watershed to an entire bay. While some of the recommendations in these plans have been implemented (for example, monitoring implemented as a result of the recommendations in the 2000 CWRMS and implementation of action items in the CMP are provided in table 1-5), others have not, mainly because of a lack of resources or coordination. Many of the management plans have similar formats for describing issues that could be extrapolated to the entire Reserve. Management plans and the waterways they address are listed in table 2 .

Many of the management and action plans integrate existing monitoring and recommend new constituents or monitoring stations be added to the current programs; however, these additions rely on an increase in funds through Federal or State grants and thus are not always implemented. This CWRMS serves to both consolidate recommendations and provide suggestions for coordinating current monitoring programs to align their respective objectives as provided by members of the PAC (excluding the USGS).

\section{Purpose and Scope}

The goal of a coordinated strategy is to provide a framework by which stakeholders in the Reserve can maximize efficiency, share data and knowledge, build partnerships, develop interdisciplinary studies, leverage existing resources to avoid overlap in water and ecological monitoring and research, and identify gaps in the knowledge and data needed for management decisions and future planning at the State and local levels. To achieve this goal, information about current monitoring and research efforts within the Reserve has been compiled and presented in this report and via an interactive mapper (http://www.sserwaterquality.us/map.html). This information was gathered from representatives of organizations working on resource monitoring and protection within the Reserve.

This report provides an overview of the roughly 20 water and ecological data collection efforts currently (2017) underway in the Reserve. The report describes the quality assurance and quality control procedures used in these efforts as well as the procedures for archiving data and metadata. Data gaps identified by the PAC and other stakeholders and recommendations from stakeholders for addressing the gaps are listed to identify monitoring needs and, in some instances, offer ways to integrate citizen science efforts. Also listed are general recommendations from stakeholders for data collection and coordination among organization and monitoring programs. These data gaps and recommendations are expected to be incorporated into a planned revision to the CMP for the Reserve. Lastly, this report describes the content of the CWRMS website and Reserve mapper and how to use them.

\section{Resource Monitoring in the Long Island South Shore Estuary Reserve}

Environmental data are collected throughout the Reserve to help address management questions regarding resources and can be used to establish trends in water quality, water quantity, or ecological conditions. The funds to maintain a monitoring 
program or conduct research typically come from Federal, State, and local government sources. A list of current monitoring programs relevant to water quality of the Reserve has been provided by stakeholders and researchers and compiled to provide a single source of information (table 4 , in back of report) and identify potential overlap and areas where efforts can be coordinated. Information about recent and ongoing programs is presented in figures 1 through 4 and in table 4 (in back of report), with additional details presented in the appendixes 1 through 3 . Ecologically relevant projects that the PAC has identified that may benefit from ancillary water-quality data are listed in table 5 .

Water-quality instrumentation used to collect data and assess the health of the Reserve has improved and evolved over the past 15 years. Instrumentation has become more sensitive and robust, models have been created and refined to better simulate water-quality processes and thereby help users understand the sources of nutrient loads to the bays and tributaries, and interactive tools and mappers have become more functional and user friendly. A partial list (based on stakeholder feedback) of what is currently being used to evaluate the water-quality resources of the Reserve is presented in table 6 .

\section{Water-Quality and Water-Quantity Programs}

Continuous and discrete data are collected throughout the Reserve to support a long-term assessment of the waters. The data inform loading and model predictions, address concerns over eutrophication, and help identify point and nonpoint sources of contamination. Although continuous measurements offer advantages over discrete sampling by capturing seasonal and diel variations in water-quality constituents at greater frequency and by detecting sudden or long-term changes that would otherwise not be identified, the equipment required for continuous monitoring is costly to install and maintain. Discrete sampling networks offer flexibility in the selection of sites and the ability to get better spatial coverage in a day, effectively providing a snapshot of water quality in the estuary. Discharge and stage of tributaries along with groundwater levels in the Reserve watershed are important for understanding the contributions of freshwater to the estuary. A comprehensive network is in place for monitoring these data (though additional streams and wells would improve the network coverage and resolution and would provide data for better modeling). Synchronization of the water-quality and water-quantity programs managed by Federal, State, Tribal, and local agencies and citizen and academic organizations around routine and event monitoring would improve efficiency and data coverage spatially.

\section{Continuous Water-Quality Monitoring}

1. Great South Bay Project/Observatory is a collaboration between the Stony Brook University School of Marine and Atmospheric Sciences, New York Sea Grant, and the New York State Department of State. Data are being collected from eight stations on the Great South Bay: Smith Point, Carmans River, Bellport, Blue Point, Islip, Tanner Park, the U.S. Coast Guard Station on Fire Island, and Barrett Beach on Fire Island. Instruments are deployed up to three months at a time, with more frequent visits in the summer because of heavy biofouling. The buoy, deployed south of Sayville in the Great South Bay, reports wind speed and direction, air temperature and humidity, photosynthetically active radiation, water temperature and salinity, chlorophyll $a$, fluorescence, and turbidity in conjunction with other data to inform the development of circulation and low-trophic-level models. Data from 2010-17 are available from (http://po.msrc.sunysb.edu/GSB/).

2. The Town of Hempstead has collected physical constituents (temperature, dissolved oxygen, salinity, turbidity, and chlorophyll $a$ ) at 6-minute intervals from East Rockaway Channel, at a site that coincides with the U.S. Geological Survey tide gage, and Wreck Lead Channel since 2010. Data are available by contacting the Town of Hempstead Department of Conservation and Waterways (Town of Hempstead, 2017).

3. The USGS operates water-quality monitoring stations to collect continuous tidal-water elevations and select water-quality constituents from Hog Island at Island Park and Reynolds Channel at Point Lookout. Waterquality constituents include water temperature, specific conductance (used to compute salinity), dissolved oxygen, turbidity, and chlorophyll $a$ and are collected from $0.5 \mathrm{~m}$ above the seabed; at Hog Island, $\mathrm{pH}$ and nitrate also are collected. Data are collected at 6-minute intervals (30-minute intervals for nitrate) and are available through the National Water Information System (NWIS) Web interface.

4. The Nature Conservancy (TNC) and USGS have deployed 20 dissolved oxygen sensors at 12 stations in the Great South Bay to investigate diurnal and seasonal variations in the hypoxic zone between Oakdale and Patchogue Bay, including Nicoll Bay south of Heckscher State Park up the Connetquot River. Sensors are 0.5 meter above the seabed and record at 6-minute intervals. Each sensor is collocated with a dissolved oxygen sensor run by SoMAS for a different study. Contact the USGS New York Water Science Center, Coram office, or TNC for more information.

5. LIShore is a SoMAS project founded in 1998 to provide real-time sea and shoreline conditions for Long Island and has been operated in collaboration with numerous sponsors and partners. LIShore presently operates six real-time observatories across the Reserve (Shinnecock Inlet, Smith Point, Seaford, Merrick, Bay Park, Point 


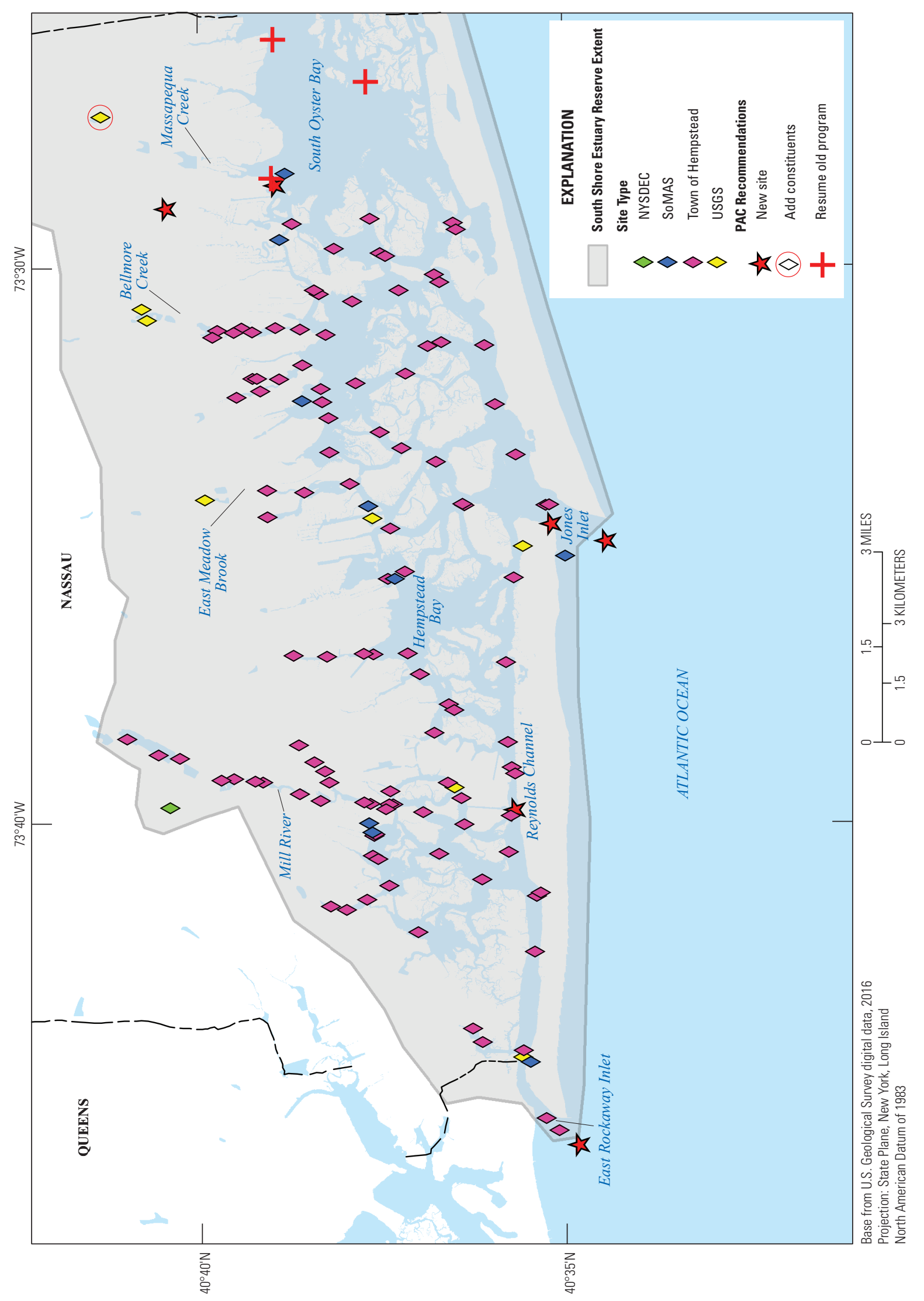

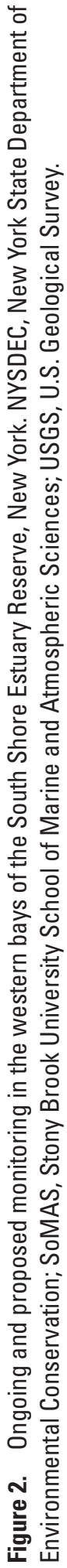



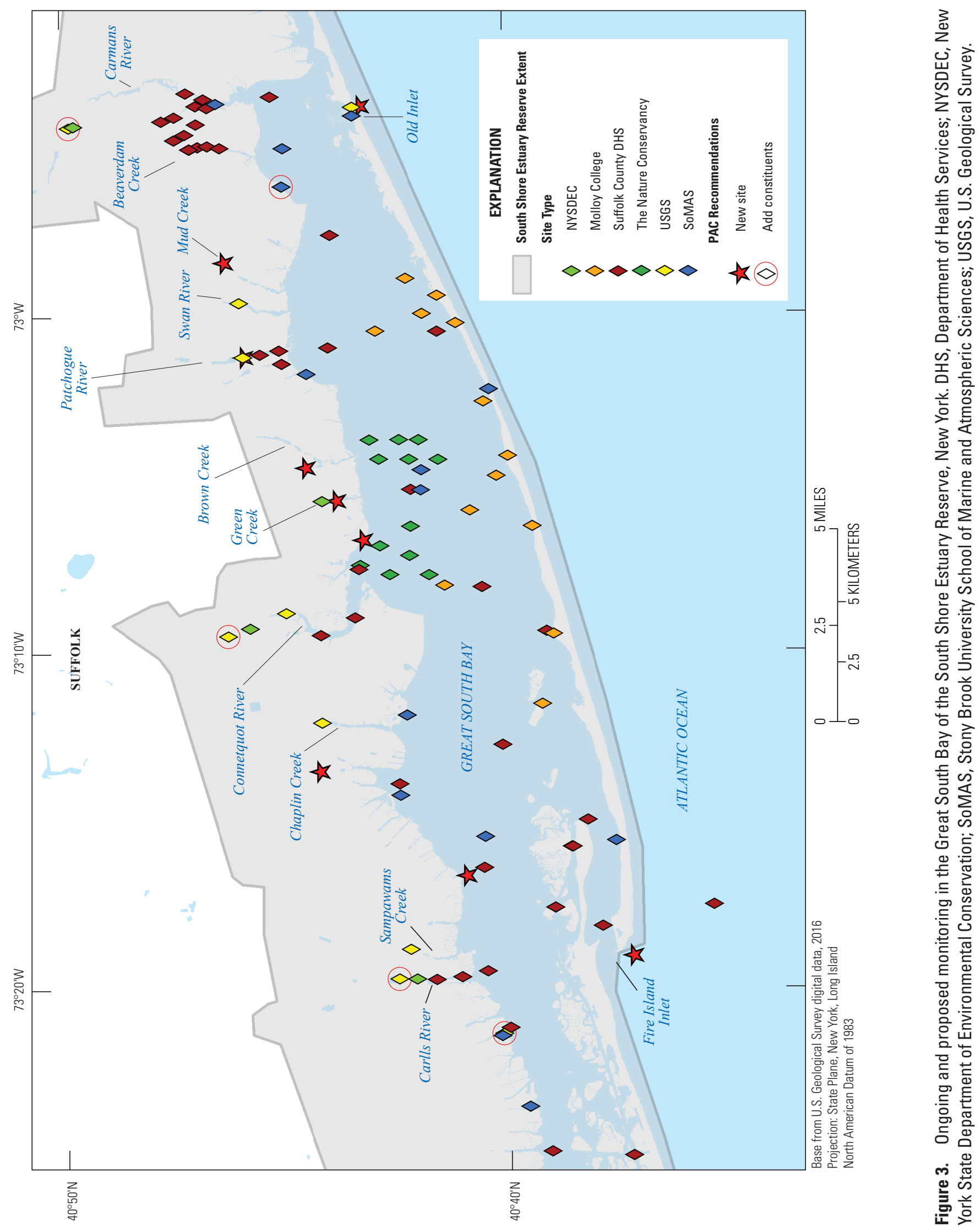

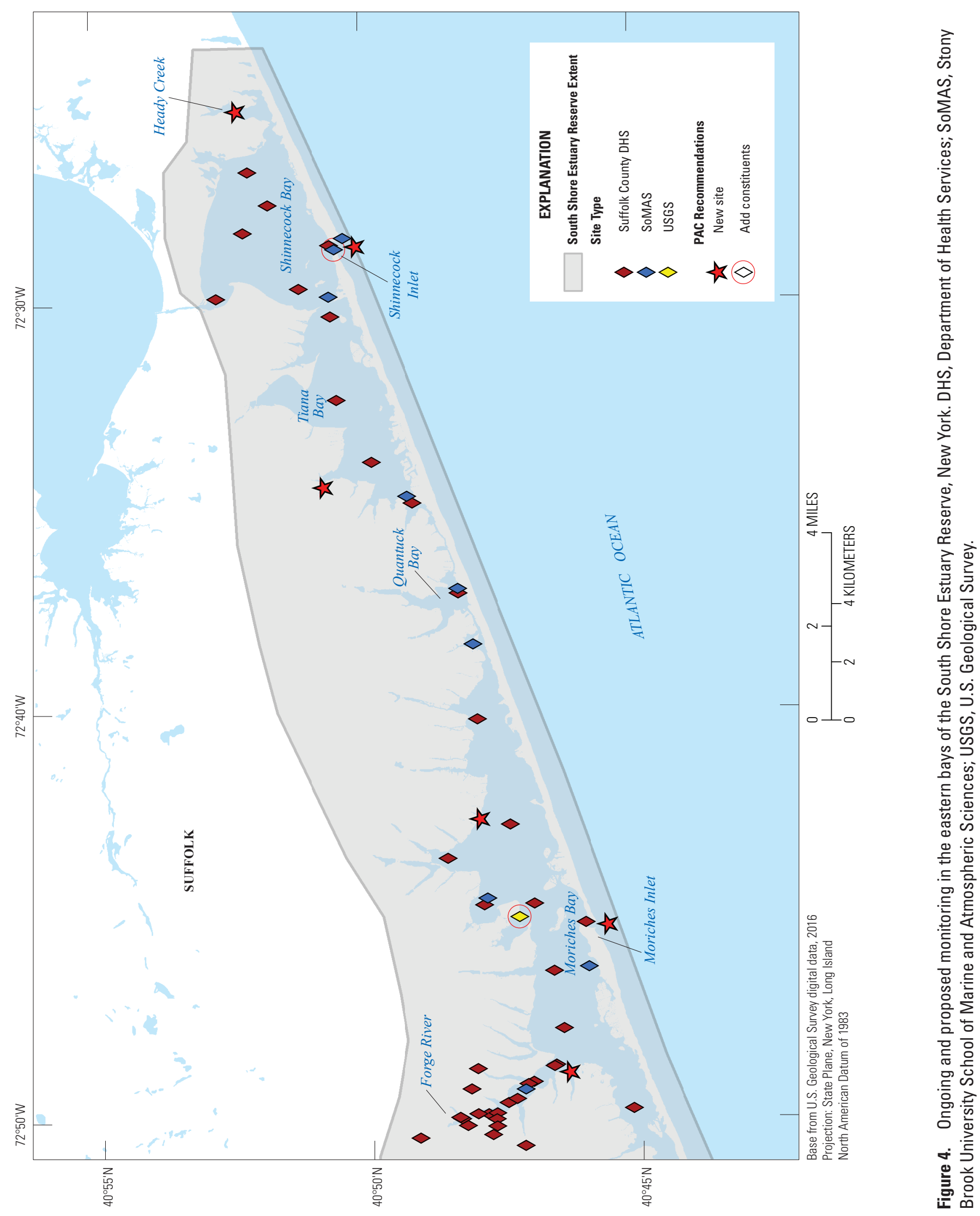


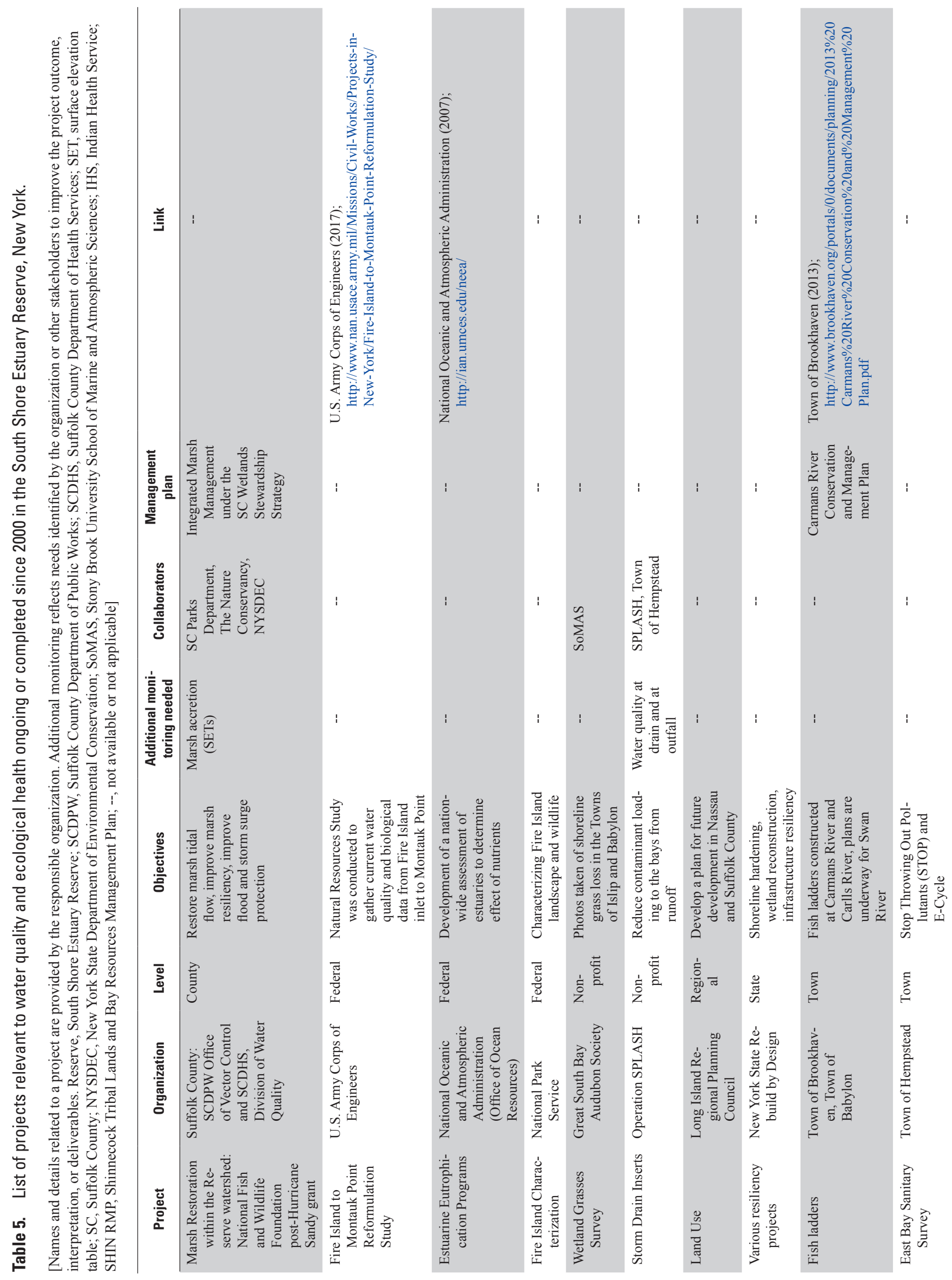




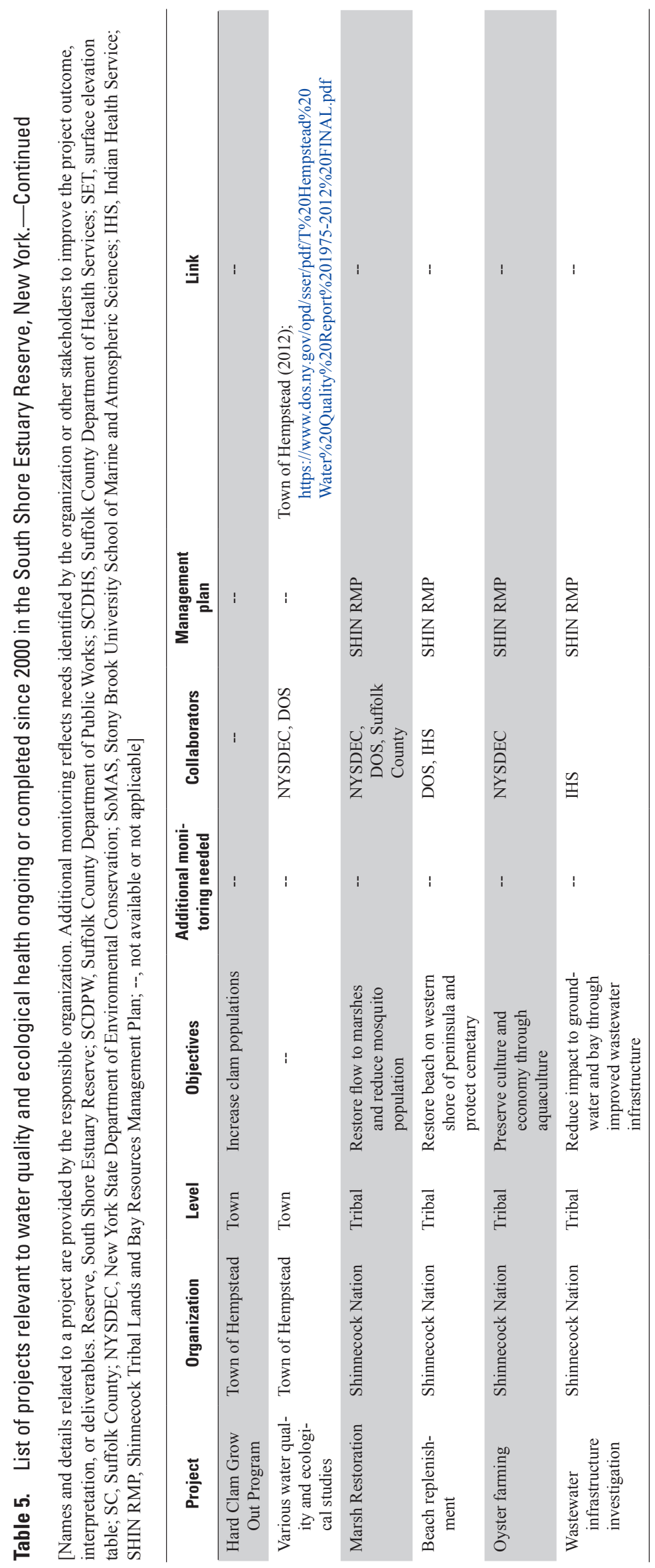


Table 6. Partial list of field equipment used or deployed for water-quality monitoring in the South Shore Estuary Reserve, New York.

[Any use of trade, firm, or product names is for descriptive purposes only and does not imply endorsement by the U.S. Government. SoMAS, Stony Brook University School of Marine and Atmospheric Sciences; USGS, U.S. Geological Survey]

\begin{tabular}{|c|c|c|}
\hline Organization & Field equipment & Constituents \\
\hline SoMAS & $\begin{array}{l}\text { Great South Bay buoy \#1: designed and built at SoMAS } \\
\text { Ocean Instrument Laboratory }\end{array}$ & WEATHER, AT, WT, SAL, CHL, TURB, PAR \\
\hline SoMAS & $\begin{array}{l}\text { Shoreline camera systems: designed and built at SoMAS } \\
\text { Ocean Instrument Laboratory }\end{array}$ & PHOTO \\
\hline SoMAS & Biospherical Instruments QSR-2150 & PAR \\
\hline SoMAS & Sea-Bird SBE16 & WT, SAL, CHL, TURB, WL \\
\hline SoMAS & Davis Vantage VUE & WEATHER, AT \\
\hline SoMAS & RM Young Marine Wind Monitor 05106 & WEATHER \\
\hline USGS & YSI 6600 & WT, SAL, pH, TURB, DO, CHL, DEPTH \\
\hline USGS & $\mathrm{EXO} 2$ & WT, SAL, pH, TURB, DO, CHL, DEPTH, fDOM \\
\hline USGS & AquaTroll & DEPTH, WT, SAL \\
\hline USGS & Satlantic SUNA & NO3 \\
\hline Suffolk County & YSI 556 Multi Probe System & WT, SAL \\
\hline Suffolk County & YSI Pro Plus & DO \\
\hline Suffolk County & Secchi disk & CLAR \\
\hline Town of Hempstead & YSI sonde & WT, SAL, pH, DO \\
\hline
\end{tabular}

Lookout) and is currently funded to expand the Shinnecock Inlet site and add one new station at Southampton. In addition to operating the observatories, LIShore provides operational and telemetry support for the Great South Bay buoy, the Bellport observatory of the Great South Bay Project, and the Town of Hempstead Oceanside water-quality station. Public data from five USGS stations are mirrored on the LIShore website at a sponsor's request (Town of Hempstead). Available data include water level; water quality (water temperature, turbidity, dissolved oxygen, salinity, and chlorophyll $a$ ); weather; waves and currents (from historic installations); and panoramic image sets, panoramas, and time-lapse photography of shorelines and inlets. Data are available at http://www.lishore.org/.

\section{Discrete Water-Quality Monitoring}

1. The Suffolk County Department of Health Services Office of Ecology monitors water quality (physical, chemical, and biological constituents) on a monthly basis at sites in Beaverdam Creek, Yaphank Creek, Little Neck Creek, Carmans River, Connetquot River, Forge River, Grand Canal, Patchogue River, Poospatuck Creek, Willets Creek, and Carlls River, as well as sampling in open water in the Suffolk County bays and inlets of the Reserve. The data for roughly 50 sites are available at https://gisportal.suffolkcountyny.gov/gis/home/item.html ?id=a4793d074dae4c95b43ac95864f0d7a0 and http://www.sserwaterquality.us. Constituents include temperature, light penetration, dissolved oxygen, salinity, conductivity, nutrients (various forms of nitrogen and phosphorous), fecal indicator bacteria, suspended solids, chlorophyll $a$, and phytoplankton. Samples are analyzed by the SCDHS laboratory; methods are approved by the U.S. Environmental Protection Agency (EPA) and comparable to the Town of Hempstead sampling methodsthough analyte suite and reporting requirements vary.

2. The Town of Hempstead monitors water quality throughout Hempstead Bay. Samples are analyzed for physical 
constituents, nutrients, metals, organic compounds, and coliforms. Samples are collected monthly from 40 sites and analyzed at the Town of Hempstead laboratory. Data are available by contacting the town's Department of Conservation and Waterways.

3. The Center for Environmental Research and Coastal Oceans Monitoring (CERCOM) at Molloy College tests 15 sites in Great South Bay to monitor for dissolved oxygen, $\mathrm{pH}$, salinity, clarity, chlorophyll $a$, and temperature. This monitoring program has been conducted since 2002 (initially in conjunction with Dowling College) on a weekly basis from Memorial Day to Labor Day. These constituents supplement the SCDHS sampling data for Great South Bay (Tanacredi, 2015).

4. The Shinnecock Environmental Department is developing a nearshore water-quality program for physical constituents, phytoplankton, and fecal indicator bacteria around the Shinnecock peninsula to support oyster farming (in cooperation with Cornell Cooperative Extension). Water temperature, $\mathrm{pH}$, and dissolved oxygen data have been collected since 2014 .

5. The New York State Department of Environmental Conservation Division of Water assessed water quality and ecologic diversity as part of the statewide Rotating Integrated Basin Studies (commonly referred to as RIBS) program at the following Reserve tributaries during 2013-15: Carlls River, Carmans River, Connetquot Brook, and Massapequa Creek. Patchogue River, Sampawams Creek, and Swan River have not been sampled under Rotating Integrated Basin Studies since the 2000 Coordinated Water Resources Monitoring Strategy was drafted. This network could be supplemented by assessing additional streams according to the same methods, including sampling at 5-year intervals, and would provide additional information on ecosystem services of the Reserve. Data are available through the Water Quality Portal (WQP) or by contacting NYSDEC (n.d.[c]).

6. The NYSDEC Division of Marine Resources monitors water quality (fecal coliform) in designated shellfish areas throughout the Reserve and determines whether an area is open for harvest (commercially or recreationally).

7. The SCDHS Office of Ecology and the Nassau County Department of Health test water from public bathing beaches for enterococci on a weekly basis from May to September (with sample collection in Nassau County conducted by the Towns of Hempstead and Oyster Bay). Data are available by contacting the SCDHS Office of Ecology.

8. The New York State Office of Parks, Recreation, and Historical Preservation tests water at public bathing beaches for enterococci on a weekly basis from May to September and posts alerts at parks if water is found to have unsafe levels of bacteria. Data are available from the Office of Parks, Recreation, and Historic Preservation or NYSDEC.

9. The USGS collects water samples at the Carmans River streamgage for nutrient and major ion (such as iron, manganese, chloride) analyses. The current study has been ongoing since 2015, and previous studies date to the 1970s. Discrete water-quality data collected at Carmans River and other tributaries to the Reserve are available through NWIS (https://nwis.waterdata.usgs. gov/ny/nwis/qwdata).

10. The National Oceanic and Atmospheric Administration (2017a) maintains an ocean monitoring buoy (water temperature, current, mean wave direction, wave period and height, and meteorological constituents) in the Atlantic Ocean, 35 miles south of the Fire Island Inlet, that provides conditions of water circulating into the bays through the Reserve inlets (NOAA, 2017a).

11. Operation SPLASH collects physical water-quality constituents ( $\mathrm{pH}$, dissolved oxygen, salinity, and water temperature) from select locations during litter removal efforts in Hempstead Bay. Data on type and quantity of litter removed from the western bays of the Reserve are available by contacting the Operation SPLASH office (Operation Splash, 2016).

12. The New York State Marine Education Association runs the South Shore Estuary Learning Facilitator Program, which is designed to provide resources to student and community groups in the monitoring of physical water-quality constituents. This program could either be expanded to include more schools or team up with A Day in the Life to increase the number of streams and frequency of data collection as part of a larger citizen science effort.

13. A Day in the Life is a nonprofit citizen organization that teaches high school students about water quality and ecology through field experience. Tributaries to the Reserve used by A Day in the Life include the Carlls River (5 sites along the river), Carmans River (21 sites), Connetquot River (5 sites), and Green Creek (4 sites). Sites are visited once per year and sampled for $\mathrm{pH}$, salinity, dissolved oxygen, turbidity, water temperature, and, during some outings, for nutrients and macroinvertebrates. Pictures of the site are often included in the metadata (A Day in the Life, n.d.).

\section{Water-Quantity Monitoring}

1. The USGS monitors the hydrodynamics of the Reserve through a series of streamgages, tidal gages, and groundwater wells. 
A. The streamgaging network includes nine tributaries to the Reserve. Continuous data are available at East Meadow Brook, Bellmore Creek, Sampawams Creek, and Swan River, and, in real time, for sites on Massapequa Creek, Valley Stream, Carlls River, Connetquot Brook (two sites), and Carmans River. In the modeling of contaminant transport, these measurements provide data necessary for determining loading of surface-water and groundwater contributions to the Reserve.

B. Tidal gaging stations in the Reserve at Shinnecock Bay, Moriches Bay (East Moriches), Great South Bay (Watch Hill and Lindenhurst), Hudson Bay (Freeport), and at the water-quality stations in Reynolds Channel and Hog Island Channel provide continuous, real-time records of tidal data and an early warning of potential flooding for emergency responders. Data for all sites are available at https://waterdata.usgs.gov/ny/nwis/ current/?type=tidal\&group_key=basin_cd.

C. Groundwater levels within the Reserve watershed boundaries are collected on a monthly basis (50 wells) and annual basis ( 65 wells) to develop water-table and depth-to-groundwater maps for Nassau and Suffolk Counties to inform models and provide information on aquifer response to weather conditions (such as drought).

2. Suffolk County monitors the hydrodynamics of the Reserve through a series of streamgages and groundwater wells.

A. Streamflow is monitored at nine tributaries to the Reserve, some of which are also a part of the USGS streamgaging network. Sites include Beaverdam Creek, Carlls River, Carmans River, Connetquot River, Forge River, Patchogue River, Poospatuck Creek, Wills Creek, and Yaphank Creek. Streamflow measurements are collected monthly from these tributaries.

B. Groundwater levels are collected monthly from wells within the Reserve watershed. Some wells overlap with the USGS groundwater-level network. Data are used to generate water-table and depth-togroundwater maps for Suffolk County.

3. The Town of Hempstead, in cooperation with LIShore, maintains tidal gaging stations at Seamans Neck Park (Seaford), Nicks Point (Merrick), and at the police dock in Mill River (Bay Park). Data for the all the sea, inlet and bay conditions for Long Island are collected continuously and available online at http://www.lishore.org/.

\section{Biological Monitoring and Surveys}

Ecology in the Reserve is assessed to various degrees by various agencies, academics, and volunteer organizations. Concerns over habitat loss, shellfish population decline, and hypoxic zones over the past decade have spurred additional monitoring and restoration efforts. However, coordination among the biological surveys and restoration projects and the water-quality monitoring projects does not always occur.

\section{Vertebrates and Invertebrates}

1. The NYSDEC and SoMAS conduct surveys of Callinectes sapidus (blue crab) populations throughout the Reserve.

2. NOAA has collected mussels and oysters as part of Mussel Watch (part of the larger National Status and Trends program) since 1986. The program has three sites in the Reserve that are sampled every 5-10 years. Bivalve tissue analysis includes polychlorinated biphenyls (PCBs), polycyclic aromatic hydrocarbons (PAHs), metals, and other primary pollutants (NOAA, 2017b).

3. The Shinnecock Tribe and Cornell Cooperative Extension assess the health of the oyster population around the Shinnecock Tribal lands of the Shinnecock Bay. The oysters are seeded and cultivated onsite, though concern over poor water quality in the western portion of the bay is growing as algal blooms become more frequent.

4. The Towns of Hempstead and Southampton each have shellfish programs, which may include hatcheries and permitting for recreational and commercial harvesting. The Town of Islip hatchery is now operated by Great Atlantic Shellfish Farms. Water-quality monitoring is limited to physical constituents within the hatchery.

5. The Center for Environmental Research and Coastal Oceans Monitoring (CERCOM) conducts horseshoe crab surveys at 44 locations in the Reserve to track declining populations. Harvesting for bait and blood and changes in water quality are believed to be the leading factors affecting populations. Climate change may also be a cause of declining populations. Tissue health studies have also been conducted in the Reserve. Data are available by contacting CERCOM (2017).

6. The NYSDEC Division of Water's Stream Biomonitoring Unit assesses macroinvertebrates as indicators of water quality (sentinels) at locations in the Reserve that cover most sites recommended in the 2000 CWRMS (NYSDEC, 2016a).

7. Cornell Cooperative Extension and the NYSDEC Division of Marine Resources conduct annual surveys for spawning horseshoe crabs at beaches throughout 
the Reserve. Data are collected to determine spawning abundance, size, and sex between May and July and are available by contacting the NYSDEC Division of Marine Resources.

8. The NPS runs a volunteer program to tag and track horseshoe crabs on the bay side of Fire Island National Seashore. Data from this program inform wildlife management decisions for the NPS and NYSDEC.

9. The NYS Office of Parks, Recreation, and Historic Preservation monitors trout in the Connetquot River, with a hatchery in Connetquot State Park that was reopened in 2015 after being upgraded to a biosecure facility.

\section{Microalgae and Macroalgae}

1. SoMAS and the NYSDEC have increased monitoring of harmful algal blooms - species classification and toxin analysis - at three locations in Shinnecock Bay as part of the Marine Biotoxin Monitoring Program (NYSDEC, n.d.[a]). These data are being used to better understand the factors leading to a bloom and the production of toxins and their effects on wildlife (both aquatic and up the food chain) (NYSDEC, n.d.[a]). Data are available through several publications and by contacting SoMAS (Christopher Gobler) (The Gobler Laboratory, n.d.).

2. Cornell Cooperative Extension has mapped locations and monitors the health of submerged aquatic vegetation, such as eelgrass, throughout the Reserve and works with Suffolk County to plant eelgrass beds in the Great South Bay and the eastern bays. Maps of the SAV beds are available on Cornell Cooperative website (http://www.seagrassli.org/).

3. Cornell Cooperative Extension and SoMAS study concentrations and the classification of phytoplankton in the Reserve. Chlorophyll $a$ concentrations are used as a proxy for phytoplankton concentration and are part of several water-quality monitoring programs.

4. The Town of Hempstead has been tracking Ulva washing up in large quantities, which is believed to be related to the high nitrogen loading from tributaries and effluent from the Bay Park Sewage Treatment Plant (STP) outfall in Hempstead Bay.

\section{Wildlife}

1. Long Island Audubon Society chapters host bird counts at locations throughout the Reserve, in particular at Captree State Park and Baldwin Bay as part of the Christmas Count, in which counts are tabulated across the country. Data are available through the National Audubon Society Christmas Bird Count web page (http://netapp.audubon. org/cbcobservation/) or by contacting a local chapter. Records are available for every year since 1900.

\section{Invasive Species}

1. The Seatuck Environmental Association surveys Phragmites in wetlands around the Reserve as part of an educational outreach program.

2. The NPS, U.S. Fish and Wildlife Service (FWS), NYSDEC, and NYS Office of Parks, Recreation, and Historical Preservation have been tracking invasive beetles - one of the management priorities over the past decade. Several species currently exist on Long Island and have affected trees within the Reserve watershed (for example, thousands of pine trees in Connetquot State Park have been cut down to prevent the spread of Dendroctonus frontalis [southern pine beetle]).

\section{Sediment-Quality Monitoring}

Marsh and bed sediment provide the substrate necessary for seagrasses, shellfish, and other organisms to live. However, sediment is also a sink for anthropogenic contaminants introduced to the water column by point and nonpoint sources. There have been few comprehensive sediment-quality monitoring programs or studies conducted in the Reserve, but those that do exist evaluate physical properties and offer insight into the fate and transport of contaminants in select areas. More studies are needed to understand sediment dynamics, contaminant degradation, and nutrient flux throughout the Reserve and to properly assess any effects that reductions of wastewater loading to groundwater may have in the water column.

1. SoMAS studies bed-sediment quality in Hempstead Bay. SoMAS, in cooperation with the Town of Hempstead Department of Conservation and Waterways, undertook a comprehensive sampling effort to assess novel wastewater tracer compounds (quaternary ammonium compounds) and metals in grab (top $5 \mathrm{~cm}$ ) and core samples collected during 2011-13-before and after Hurricane Sandy. Data are available in a publication by Doherty and Brownawell (2013) and by contacting SoMAS (Bruce Brownawell).

2. NOAA collects sediment at sites sampled for shellfish as part of the Mussel Watch program - sediment samples are analyzed for PCBs, PAHs, metals, and other primary pollutants. Data are available at NOAA's National Status and Trends web page (https://products.coastalscience. noaa.gov/collections/ltmonitoring/nsandt/default.aspx).

3. The USGS and Suffolk County Vector Control assess sediment and water from marshlands along the south shore of Suffolk County for pyrethroid and other 
insecticide residues following applications targeting adult or larvae mosquitoes.

4. The Nature Conservancy and NPS established surface elevation tables (SETs) in marshes throughout the Reserve to track accretion or erosion of sediment from shoreline marshes and marsh islands. The Nature Conservancy sites include North Green Sedge, Lawrence Marsh, and Pine Neck. The NPS sites include Old Inlet, Great Gun, and Watch Hill.

\section{Atmospheric Monitoring}

Maintaining weather and long-term climate data is important for correlating changes in water quality (for example, $\mathrm{pH}$ and water temperature) and sea-level rise. Air-quality monitoring in the Reserve is limited and unsystematic. A program to assess nitrogen in air (those viable with current technology) and precipitation, as well as other pollutant concentrations within the Reserve boundaries, would inform models where nitrogen loading is estimated to be a sizeable part of the overall load through deposition.

1. The National Weather Service maintains weather stations at Upton, West Sayville (CERCOM), and Long Beach (Town of Hempstead) for real-time monitoring of air temperature, wind speed, and precipitation. Data are necessary for forecasting and are available through the NOAA website (https://www.ncdc.noaa.gov/data-access/ land-based-station-data).

2. A USGS real-time water-quality monitoring gage at Reynolds Channel records the following weather constituents: precipitation, wind speed, wind direction, temperature, humidity, and barometric pressure. Data are collected at 6-minute intervals.

3. LIShore observatories at Merrick, Smith Point, and Shinnecock Inlet record the following weather constituents: precipitation, wind speed, wind direction, temperature, humidity, and barometric pressure. Data are collected at 5-minute intervals at Merrick and Shinnecock and at a 1-minute interval at Smith Point.

\section{Quality Assurance and Quality Control, Metadata, and Data Archives}

Documenting the level to which field protocols and laboratory methods are implemented during collection and analysis of environmental data is an important component of determining data reliability. It is critical to preserve information about quality assurance and quality control (QA/QC) methods from all studies, analyses, monitoring programs, and projects. Any associated QA/QC data should be incorporated into the metadata. Metadata associated with water or biological samples collected or surveys conducted should also include references to methods of collection and analysis, and the metadata should be provided with the data release. Lastly, archiving data and metadata as a complete dataset in a safe and accessible digital repository is necessary, and though data storage and dissemination can be challenging with limited resources, tools have been developed by the Federal government to ensure these and other data can be preserved in perpetuity.

\section{Quality Assurance and Quality Control}

The extent to which field and laboratory protocols incorporate quality assurances depends on the available resources, project objective, and personnel experience and training. Most Federal, State, and local government water-quality monitoring follows established protocols for field procedures and laboratory methods. These established protocols ensure that the quality of data meets the expectations of lawmakers and other stakeholders providing funds for assessing issues concerning human and ecological health within the Reserve. Academic and some nonprofit organizations typically have research-based quality control and internal checks that can provide high-quality data, and it is important to maintain these records (in addition to what is required by those sponsoring the monitoring) so that the data can be used with confidence. Many of the accepted procedures for preventing contamination of samples, collecting the proper number of quality control samples (replicates, blanks, spikes), identifying issues with sampling equipment, and properly calibrating and logging instruments are found in U.S. Environmental Protection Agency guidelines (EPA, 2014, 2016) and summarized in the 2000 Coordinated Water Resources Monitoring Strategy Current QA/QC protocols followed by organizations within the Reserve are presented in table 4 (in back of report). A summary of the information that would be useful for tracking and monitoring QA/QC should include the following:

- Protocol(s) followed (for example, instruction manuals or methods paper)

- Logs of field checks of constituents with calibrated monitors

- Documentation of corrections applied to data based on internal checks and procedures for data corrections (for example, formulas used to calculate value offsets when biofouling of a water-quality instrument caused a drift in data)

Since 2000, and with the implementation of the 2001 Comprehensive Management Plan, nongovernmental organizations have been collecting and providing a growing volume of the data necessary for identifying and understanding issues of poor water quality in bays and tributaries. Integrating the variety of data that are collected via different methods and protocols can be facilitated by first identifying the level of 
QA/QC and scientific rigor that went into collection, analysis, and interpretation. In general, the New York State Department of Environmental Conservation does not use citizen science or academic research data for regulatory purposes unless data collection is performed under a quality assurance project plan with analyses being conducted by an approved laboratory.

\section{Quality Assurance Project Plans}

A QAPP describes the necessary quality assurance procedures, quality control activities, and other technical activities that will be implemented as part of a specific project or program. The data collection procedures and training of responsible parties documented in a QAPP are reviewed by the EPA and (or) the State to ensure sufficient quality to meet project objectives (EPA, 2002). Developing a versatile QAPP for groups interested in filling data gaps but possessing varying degrees of expertise and resources can be challenging. Each organization receiving EPA or State funding for environmental monitoring is required to have a QAPP, or QAPP-like document, submitted prior to beginning the project. Selecting the appropriate protocol for collecting field data is important for citizen science and nonprofit groups interested in providing supplemental data to established monitoring networks, and resources exist to assist these organizations, which may find developing an effective protocol challenging without expert guidance. Therefore, having a standardized template tailored to the environmental aspects (for example, hydrology or ecology) of the Reserve could help save time and resources.

"The General QAPP for Long Island Sound Volunteer Coastal Monitoring" (Vaudrey and Gallagher, 2013) provides a template that organizations interested in collecting waterquality or ecological data within the Long Island Sound can use to satisfy one of the requirements for funding through State and EPA grants. The general QAPP provides the necessary components for sampling within an estuarine and freshwater tributary: project management, data acquisition, assessment and oversight, and data validation and usability. This QAPP could be adapted for use within the Reserve. Other examples of volunteer monitoring programs with QAPPs that could serve as examples for water-quality monitoring within the Reserve include the following:

- Friends of the Bay (Oyster Bay, New York) conducts water-quality and ecological assessments in streams and the open waters of Cold Spring Harbor and Oyster Bay following a pair of approved QAPPs (Friends of the Bay, 2006; Fuss \& O’Neill, Inc., 2007). Following these protocols and ensuring proper QA/QC has allowed for results to contribute to a watershed action plan and annual state of the watershed reports.

- The Hempstead Harbor Protection Committee (Hempstead, N.Y.) coordinates watershed protection plans and water-quality sampling on behalf of the municipalities surrounding Hempstead Harbor (Hempstead Harbor Protection Committee, 2017).
- Save the Sound (New Haven, Connecticut) is working on a more general water-quality sampling protocol than their current QAPP (Connecticut Fund for the Environment, 2016) for their volunteers that offers several methods for collections but has a common method for reporting and ensuring proper $\mathrm{QA} / \mathrm{QC}$ standards are practiced.

- The River Project (New York City, N.Y.) has a citizen science project for enterococci sampling in the New York-New Jersey Harbor Estuary Program - weekly samples are collected following an established QAPP and EPA-approved methods and are used to determine fecal indicator bacteria concentrations near permitted combined sewer overflows and storm drain outfalls.

From these and other volunteer monitoring programs, mediaspecific documentation can be generated and stored at the Reserve Office for incorporation into project proposals.

\section{Proposed Ranking of Data}

Qualifying data on the basis of the procedures and methods implemented does not imply data without the highest level of QA/QC are not useful; rather, qualification is a metric to suggest a way in which data could be used. A tiered approach has been adopted by some State and Federal agencies to indicate the extent to which records have been kept and calibrations performed and the quality of analyses. Efforts are underway in other estuary programs (for example, the Long Island Sound Study [LISS] and Peconic Estuary Program [PEP]) to implement a tiered system to help describe the quality of data collected by all organizations. Given that data collection by citizen science groups throughout Long Island typically is not coordinated with respect to standardized methods, the members of the Project Advisory Committee recommend that the Reserve Office citizen science coordinator directly interact with outreach coordinators from the LISS, PEP, and other groups operating outside the umbrella of these organizations to ensure standardized and approved options are available to all groups wishing to collect the highest quality data for their waterbody or ecosystem of interest.

One example that could be adopted by the Reserve Office for data collected within the Reserve comes from the Indiana Department of Environmental Management, which has created a guidance document for data that are being accepted into its water-quality database program (Arthur, 2015). A tiered system allows for data to be assigned a rank, and the system can be applicable to past, current, and future datasets. It is important to note that the datasets, not the organizations, are ranked. This scheme of ranking datasets in tiers 1 through 3 has been applied to the datasets indicated by Reserve stakeholders whose monitoring programs are presented on the South Shore Estuary Reserve CWRMS website.

- Tier 1 represents data of unknown quality, mainly because metadata or QC data do not accompany the 
records or because an approved QAPP (or QAPPlike document) was not used in field collection and analyses. Examples include results from a citizen science colorimetric test kit of water quality and wildlife surveys by volunteers organized by a group that does not follow an established protocol. These data are usually collected by groups interested in providing basic information about a system and lacking the resources, expertise, or need to follow advanced protocols for field data collection and methods of analysis approved by a regulatory agency. These data are informational and not legally defensible.

- Tier 2 represents data collected by groups or agencies that follow an approved QAPP but use research-level or unapproved methods for analyses. Examples include academic research that was collected and published in a thesis and data collected and analyzed by volunteer organizations with an approved QAPP that used a handheld spectrofluorometer following methods of EPA-approved test kits. These data could be used to drive additional research and supplement modeling efforts but are not necessarily legally defensible or usable for policy.

- Tier 3 represents data that have been collected, processed, and analyzed according to an approved EPA or other State or Federal method that has undergone intensive review within the discipline. All data and metadata are quality assured and records are archived. These data can be used to support modeling efforts; write policy, human and environmental thresholds (such as maximum contaminant limits), and loading regulations (such as total maximum daily loads [TMDLs]); and are legally defensible.

Included in table 4 (in back of report) are ranked values based on this tiered approach, and these ranks are included in the attribute table of the programs displayed on the South Shore Estuary Reserve CWRMS mapper (http://www.sserwaterquality.us/map.html).

Optimizing QA/QC can be challenging - the amount of quality control needed to reach the desired level of confidence and statistical deviation can be calculated on the basis of sample size and distribution (Wilde, 2006) and can easily increase the project budget beyond means. Budget and resource restrictions typically limit the quality of data that can be collected and are particularly challenging for citizen science organizations. For this reason, procedures such as collecting 5 percent of the sample set for quality control, as blanks, replicates, and other checks, are established for most types of assessments implemented. Advanced environmental monitoring equipment is expensive, as is laboratory analysis by EPA-approved facilities. Equipment loaner programs, such as the newly initiated EPA citizen science loaner program (https://www.epa.gov/citizen-science/additional-resourcescitizen-science-environmental-protection), could be useful to help establish a monitoring program for organizations looking to address a specific data gap. Facilitating the loaner program process, along with providing guidance on use and calibration, would improve the usability of data collected and potentially encourage greater participation.

\section{Defining and Standardizing Metadata}

Proper collection and association of metadata would improve data usage now and in the future, especially as field crews and project leads change and projects end. This is particularly important for government agencies because data are typically used to make management and policy decisions. Monitoring programs by agencies that do not follow a QAPP should follow published protocols or manuals, which can be modeled from State and Federal data collection agencies (EPA, 2002). Though typically included in a data collection QAPP and protocol, at a minimum, the following information about sample locations, sample collection, and sample analysis must be recorded and stored with the data to ensure data usability:

1. Field information

A. Organization site name

B. Global Positioning System (GPS) coordinates and datum

C. Monitoring equipment

I. Make, model, and serial number(s)

II. Calibration and service notes, including date and time performed

D. Project coordinator or principle investigator with contact information

E. Field crew names

F. File names of all site pictures (even if they are not to be released with data)

G. Weather (as bad weather may influence sampling conditions)

H. Sea, bay, or stream conditions (if applicable)

I. Site identifiers of any other sampling programs collocated at site

2. Sample collection

A. Make and model number of sampling equipment

B. Type of samples collected

C. Lot numbers of any preservatives used (for example, dropper acid for vials of volatile organic compounds) 

D. QAPP and (or) protocol/procedure(s) followed
E. Chain of custody documentation

3. Sample analysis
A. Sampling processing and hold time information
B. Document(s) or procedure(s) followed
C. EPA method number or equivalent (if applicable)

\section{Electronic Field Forms}

Paper field forms listing the required information are typically used; however, electronic field form applications are available for free or are easy to develop and use on smartphones or portable field devices. The main advantage of these applications is the intrinsic acquisition of metadata from the device operating system, including GPS and other active tools that can be standardized to reduce the burden of manual entry by the field crew. One example is Open Data Kit (https://opendatakit.org/). Applications such as this allow most field tablets or smartphones to be used to record field data, with the options of automatically populating fields with common entries and selecting entries from dropdown menus, expediting the data-entry process and minimizing transcription and user error. A standardized spreadsheet is created upon upload (in machine-readable, comma separated variable [CSV] format) to the Open Data Kit server. Field photos are also transferred with the form, and their file names are automatically stored in the spreadsheet. Enketo (https://enketo.org/) is another service with similar capabilities and a similar user interface that provides support for field forms.

\section{Metadata Database}

Through this CWRMS effort, a repository for data collection programs and studies throughout the Reserve has been created. Members of the PAC have indicated the need for metadata and relevant $\mathrm{QA} / \mathrm{QC}$ data, along with information about the intended use of the data by the organization (for example, informational only, promoting additional monitoring, or influencing regulation), to be maintained and for programs to be reviewed by the Reserve Office to ensure future programs document and report the information needed to properly catalog their work. As is currently done on an annual basis, a request for information on Reserve-related studies can be sent to researchers by the Reserve Office. However, this form could be provided digitally to allow for easy database entry and updating. Additional information from researchers, such as a list of procedures and methods used and a data plan to be released prior to doing measurements, can be requested in order to track what science is being conducted in the Estuary. This would be similar to the National Park Service Integrated Resource Management Applications forms for research conducted within the Office of Parks, Recreation, and Historic Preservation property (NPS, n.d.). The Reserve Office would also provide guidance for QA/QC documentation and metadata acquisition.

\section{Standardizing the Archival of Data}

State and local government agencies with data not housed in publicly accessible databases have expressed concern over the lack of resources and staff to dedicate to converting paper records or older digital records to electronic formats amenable to online databases. Deciding on the most compatible and transferable database is also a concern. Converting historical records and documents to digital format can be time consuming and prone to transcription errors. Assigning the appropriate metadata and QA/QC information to historical data can also be challenging but provides the context necessary to fully use results from past studies and programs.

Both Nassau and Suffolk Counties have historical environmental data that are filed away, with some historical data, including most of the data collected in the past 10 years, available upon request in electronic spreadsheets. Preserving historical environmental data originally collected on paper from the Reserve in an electronic format would require considerable effort and resources. Formatting the data to modern standards and migrating it to an open-source database, such as one operated by the Federal government, is critical to preserving data after a project has ended. In lieu of a publicly accessible database hosted by each organization (government, academic, or nonprofit), two centralized databases can be utilized for this purpose - the Water Quality Exchange (WQX) hosted by the National Water Quality Monitoring Council (a collaboration between U.S. Geological Survey and U.S. Environmental Protection Agency) and USGS ScienceBase.

As previously noted, there is also a need to account for QA/QC documentation whenever possible (or to mark a dataset as having "no QA/QC available"). Preservation of metadata and QA/QC information associated with a dataset allows documentation of changes in methods over the term of the project or study, and QC data should be stored as individual records and (or) as part of the metadata associated with the environmental dataset, depending on the extent to which the QC data are generated. The WQX and ScienceBase offer different ways to present QC data. Quality assurance methods can be loaded to the WQX or referenced in ScienceBase along with QC data and information. These databases are queried by and discoverable through clearinghouses such as https://www.data.gov.

The WQX allows for the storage of water-quality and biological data in the EPA Storage and Retrieval (STORET) database and provides a standardized way in which researchers and other organizations collecting data within the Reserve can ensure data are available to the public and preserved in perpetuity. STORET can host water-quality, biological, habitat, and indices data and is available at https://www.epa.gov/ 
waterdata/storage-and-retrieval-and-water-quality-exchange. An account is required through the EPA Central Data Exchange (https://cdx.epa.gov/), and online tools provided by Central Data Exchange allow for data fitted to standardized tables to be converted to machine readable files (Extensible Markup Language [XML]) for upload to the WQX. Templates for organizing data (Microsoft Excel format), as well as for identifying methods and some basic metadata associated with the data, are available through the instructional website (https://www.epa.gov/waterdata/water-quality-exchange-webtemplate-files). A project name and code is required to create a node for the agency in the WQX. Once created and verified by the EPA, water-quality and ecological data can be transformed and uploaded. The data are then accessible through the Water Quality Portal, which also queries the USGS National Water Information System database, USDA STEWARDS (Sustaining the Earth's Watersheds-Agricultural Research Database System), and others for a comprehensive and dynamic set of data. The WQX and STORET are available to any organization wishing to upload data-nongovernmental organizations require approval prior to creating a node.

ScienceBase provides flexibility for data storage in that the data do not need to be in a specific format and can be presented in a variety of file types, from spreadsheets to model data outputs. Quality control data can be tabulated or presented in a Portable Document Format (PDF) document and uploaded directly to the site. Additionally, metadata files (created using the Online Metadata Editor tool, available through the site, and loaded separately from the data being uploaded) can include as much information as needed to describe the way in which data were collected, analyzed, and processed, including the QA/QC. An account and collaborative agreement on a USGS research or monitoring project (at the present time) is required (USGS, 2017b).

Furthermore, a new service being introduced by the USGS soon will allow researchers outside the USGS to use crowdsourcing through an open-source program to upload and populate databases from digitized field forms as part of the Data Rescue Program (Wippich, 2012).

\section{Data Gaps and Specific Recommendations}

Gaps in the monitoring and management of resources ultimately exist because of limited funding. For a lack of data in a given waterbody or area to be considered a gap, a need must exist for such data to help answer questions related to human or ecological health concerns resource managers face. The recommendations presented in this section for monitoring water, biological, air, and land resources are summarized from stakeholder meetings. In many areas, the data required to inform current management plans are not being collected at the necessary frequency and (or) spatial resolution because the number of variables and capacity to monitor them are cost prohibitive. Issues of limited funding can be addressed in part by following established guidelines for the collection of appropriate data through the coordination of government agencies, academia, and nonprofit and community groups. Some examples include intensive localized studies that are transferable to other locations within the Reserve, creating modeling and decision support tools, monitoring proxy constituents, and citizen science monitoring programs.

In this section, opportunities for synergy among programs are also noted to provide information necessary for proposing collaboration among governmental, institutional, and community organizations, which can save time and resources while generating data. Appendix 1 (tables 1-1 through 1-8) lists the monitoring programs and recommended expansions of locations and constituents identified in the 2000 Coordinated Water Resources Monitoring Strategy, along with updates as to which have been fulfilled. By coordinating existing programs and capitalizing on the willingness of volunteers and citizen scientists to participate in research and monitoring efforts, data can be collected in areas where established programs are not able to operate, which can help to keep up with the growing demand for data in the groundwater and surface waters of the Reserve. Examples of data gaps include the need to expand the water-quality monitoring network to include additional sites or constituents to help identify elevated levels of runoff-related contaminants and the need for additional continuous, in situ nutrient-monitoring stations to help refine loading budgets and models. In addition to the specific monitoring recommendations outlined in this section, several overarching PAC recommendations are summarized to reinforce current efforts and introduce new ways to approach monitoring and data management; these new approaches are presented in the section "Coordinated Water Resources Monitoring Strategy Website."

The following sections provide an overview of data gaps identified by stakeholders in the areas of water resources, ecology, estuarine dynamics, air resources, and infrastructure. For each gap, one or more recommendations for addressing the given gap are detailed. A complete listing of data gaps, along with associated constituents and management issues from table 3 that filling the gap can address, can be found in table 7 . A "priority" ranking for filling the gaps, based on a survey of PAC members, is also presented in table 7 .

\section{Water Resources}

Presentations by PAC members on water-resource monitoring gaps focused on water-quality and water-quantity constituents specifically needed to inform management decisions.

WATER gap 1.-More real-time water-quality monitoring is needed to provide information to decision makers, such as why water-quality standards are not being met for a waterbody on the New York State Department of Environmental Conservation303(d) list, indications of conditions leading to and during fish kills, relative contributions of nutrient loading, and potential sources of contamination. 

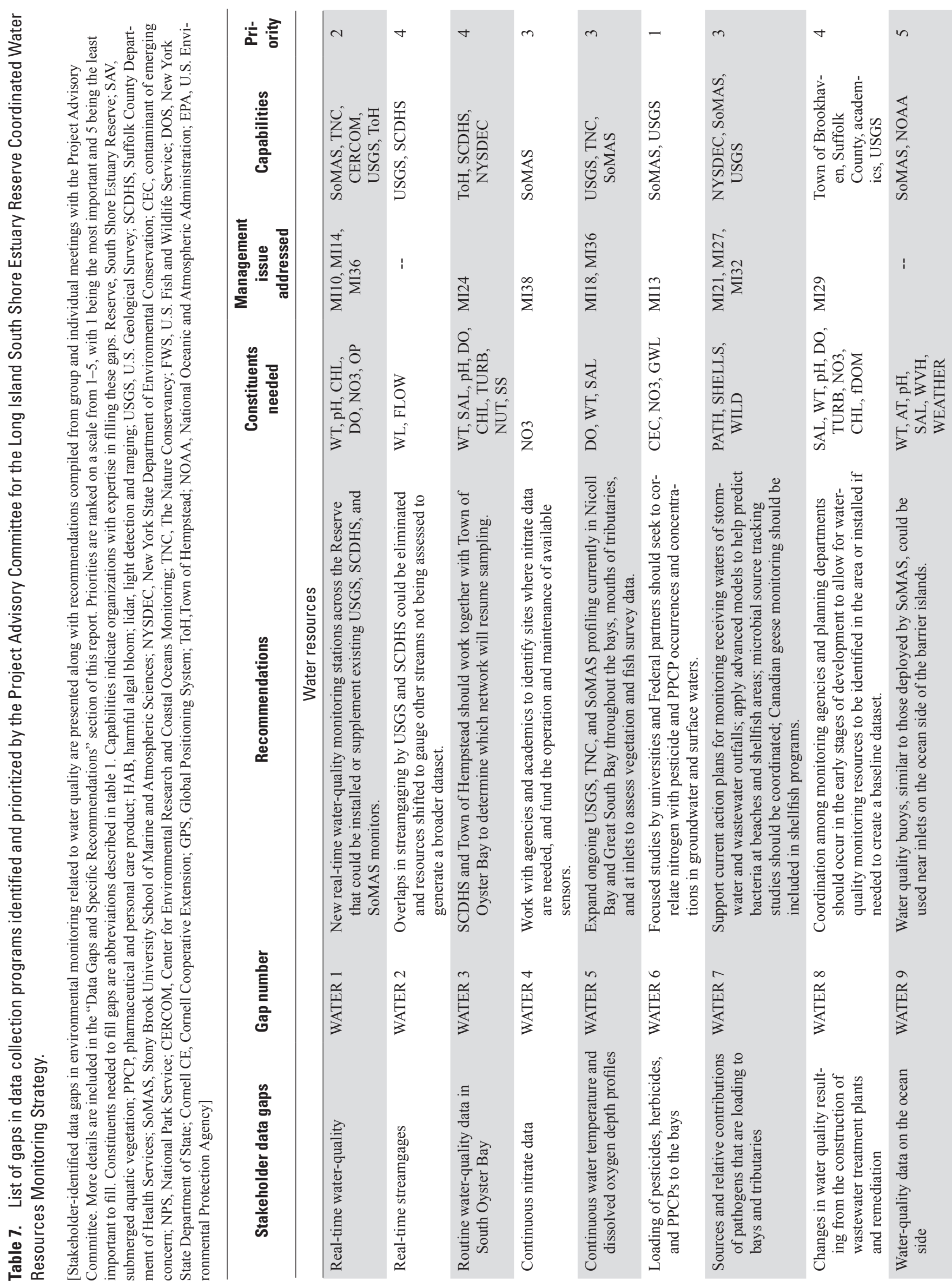


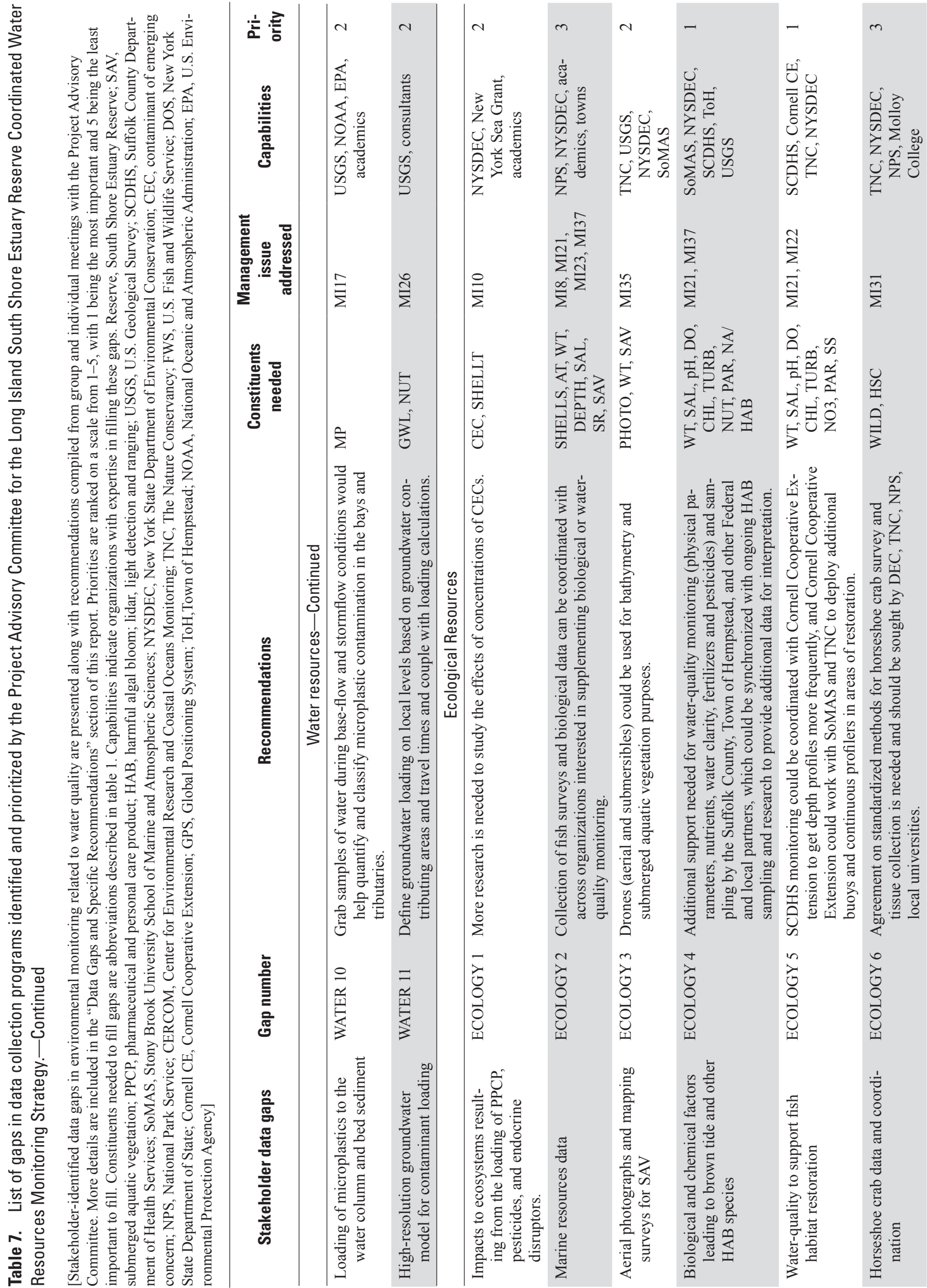



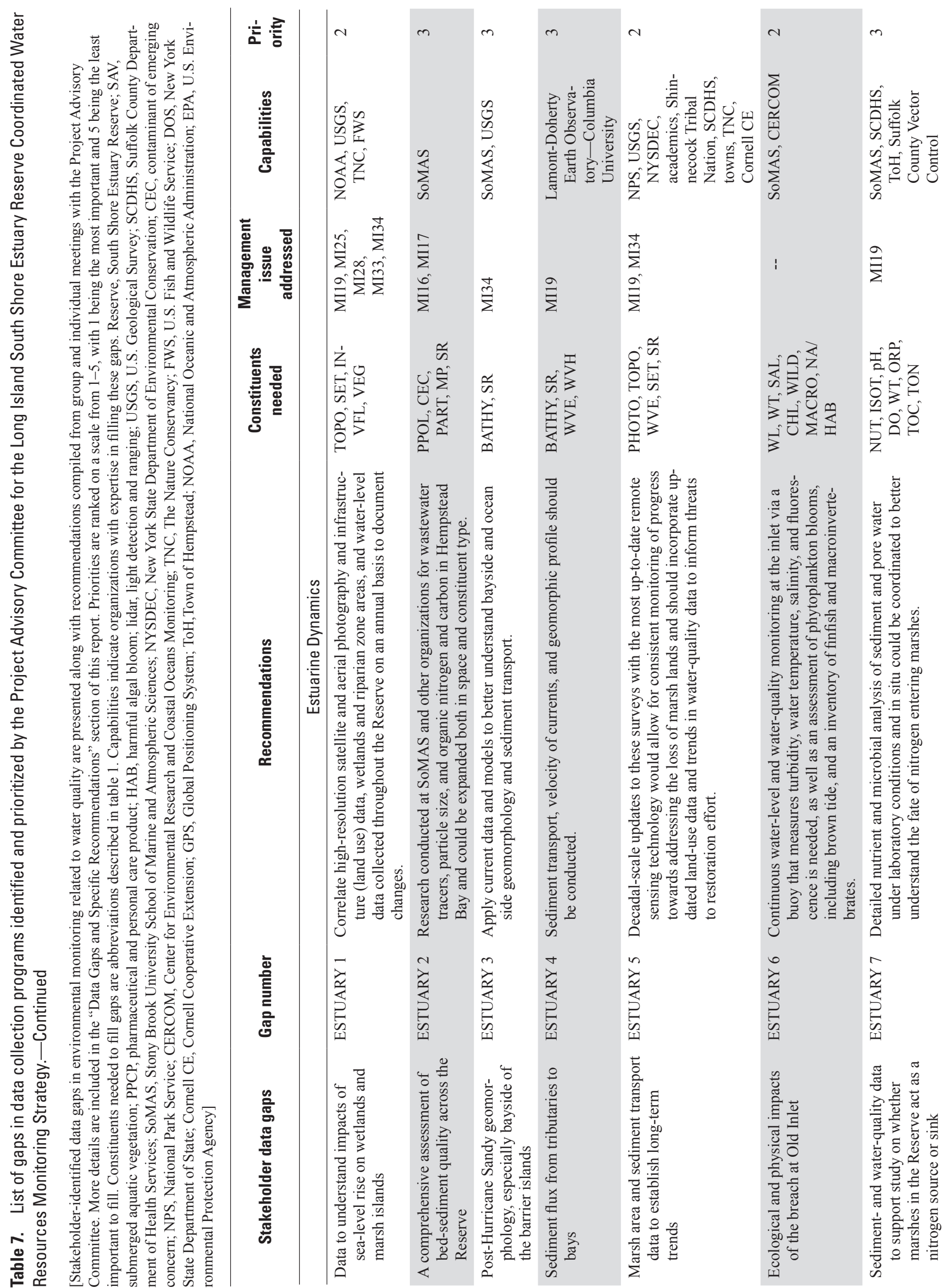

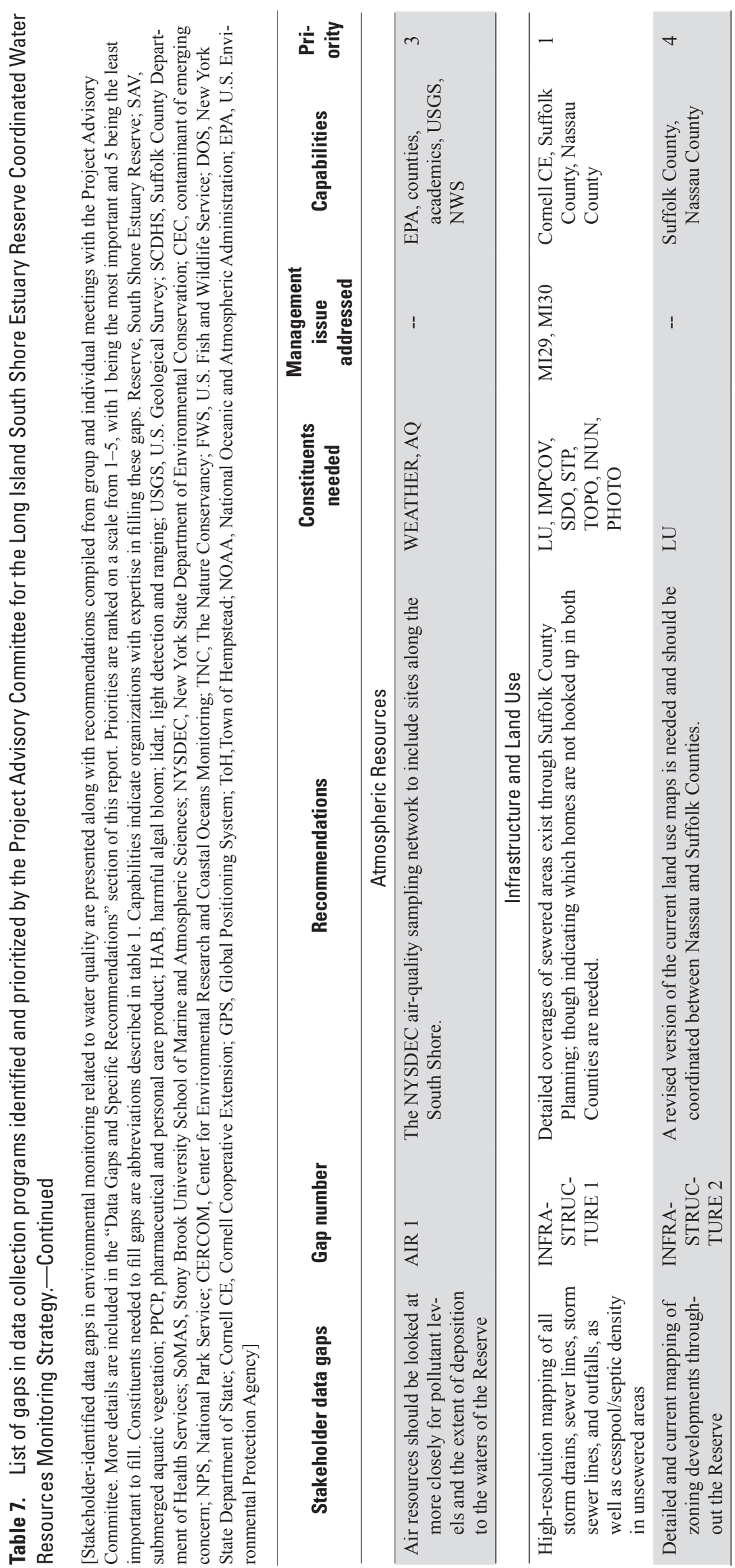
Recommendations to address WATER gap 1.-Overlaps in water-quality monitoring by the U.S. Geological Survey and Suffolk County Department of Health Services (SCDHS) could be eliminated and resources shifted to monitoring other streams not being assessed to generate a broader dataset. New real-time water-quality monitoring stations across the Reserve that could be installed or supplement existing USGS, SCDHS, and Stony Brook University School of Marine and Atmospheric Sciences monitors include stations at Shinnecock Bay, Moriches Bay, Forge River, Patchogue River, Carmans River, Nicoll Bay, Connetquot River, Carlls River, Lindenhurst (the current [2017] USGS station could be upgraded), South Oyster Bay, Massapequa Creek, Meadowbrook Creek, and East and Middle Bays between Point Lookout and Jones Inlet. An additional station should also be added in Great South Bay (a site on Great South Bay Bridge should be considered). Tributary sites should include stage and flow; bay sites would include water-level elevation. The following in situ water-quality constituents are needed: water temperature, $\mathrm{pH}$, total algae (phycoerythrin) and chlorophyll $a$, dissolved oxygen, nitrate, and orthophosphate.

WATER gap 2.-More real-time streamgages are needed in streams prone to flooding to inform resource managers of runoff volumes for loading calculations and to notify emergency responders of potential flooding events.

Recommendations to address WATER gap 2.-Overlaps in streamgaging and water-quality testing by the USGS and SCDHS could be eliminated, and resources could be shifted to gage other streams not being assessed to generate a broader dataset. Streams with fish runs or dam modification should be prioritized. County data needs to be made available online via the county portal or data.gov.

WATER gap 3.--Routine water-quality monitoring in South Oyster Bay has not been conducted in over 10 years and should be reinstated.

Recommendations to address WATER gap 3.-SCDHS and the Town of Hempstead should work together with the Town of Oyster Bay to determine which network will resume sampling of at least the three original sites in South Oyster Bay for constituents consistent with current Great South Bay and Hempstead Bay monitoring.

WATER gap 4.--More continuous nitrate data are needed to understand how changes in water temperature affect nutrient concentrations.

Recommendations to address WATER gap 4.-Agencies and academics should collectively identify sites where nitrate data are needed and to fund the operation and maintenance of available sensors.

WATER gap 5.-There is a need for continuous water temperature and dissolved oxygen depth profiles in bays throughout the Reserve in order to relate diurnal and seasonal fluxes to the health and loss of submerged aquatic vegetation (SAV) (such as eelgrass), flushing dynamics, and shellfish health.

Recommendations to address WATER gap 5.-Dissolved oxygen profiles and bottom temperature monitoring is ongoing since 2015 in Nicoll Bay and Great South Bay as part of an effort by the USGS and The Nature Conservancy to assess the areas of hypoxia of Great South Bay. SoMAS has also deployed the same dissolved oxygen sensors at these sites for a different study. This type of monitoring could be expanded throughout the bays, mouths of tributaries, and inlets and could be used to assess vegetation and fish survey data.

WATER gap 6.-Insufficient data are available on the loading of pesticides, herbicides, and pharmaceuticals and personal care products (PPCPs) to the bays, marshes, and ecosystems of the Reserve. Similarly, effects on ecosystems resulting from the loading of these anthropogenic compounds, such as endocrine disruption in finfish, are not well understood.

Recommendations to address WATER gap 6.-Focused studies by universities and Federal partners should seek to correlate nitrogen with pesticide and PPCP occurrences and concentrations in groundwater and surface waters. To develop correlations, localized and regional studies are needed that monitor nutrients in groundwater and tributaries and the concentrations of PPCPs and endocrine-disrupting compounds. Such studies are especially needed in shallow groundwater with short traveltimes to the bays and where sewage treatment plants discharge.

WATER gap 7.- Sources and relative contributions of pathogens that are loading to bays and tributaries throughout the Reserve need to be better defined; pathogen sources must be differentiated between wildlife and human.

Recommendations to address WATER gap 7.- State or Federal funding should be sought to support current action plans for monitoring receiving waters of stormwater and wastewater outfalls discharging to the Reserve.

Additional recommendations to address WATER gap 7.Apply advanced models, such as USGS Nowcast, to help predict bacteria at beaches and shellfish areas given a set of constituents (that are collected in real time) by using data collected by Suffolk and Nassau Counties, the NYSDEC, towns, and SoMAS. The NYSDEC has modeled some effects but does not have field data to corroborate models.

Additional recommendations to address WATER gap 7.Microbial source tracking studies should be coordinated. For example, coordination could include looking at wildlife surveys, DNA/RNA sequencing, and polymerase chain reaction (PCR) methods.

Additional recommendations to address WATER gap 7.Canadian geese monitoring should be included in shellfish programs to determine impacts (correlate geese survey [spatial and temporal] data with closures of areas to shellfishing and pathogen monitoring data).

WATER gap 8.-There is a need to track changes in water quality resulting from the construction of wastewater treatment plants (for example, in Mastic/Shirley), redevelopment of existing wastewater infrastructure (for example, diverting effluent from Bay Park Sewage Treatment Plant), and remediation (for example, any remediation of Forge River bed sediment). 
Recommendations to address WATER gap 8.-Coordination among monitoring agencies and planning departments should occur in the early stages of development to allow for water-quality monitoring resources to be identified in the area or installed, if needed, to create a baseline dataset. For Mastic/ Shirley, the Town of Brookhaven along with Suffolk County, university partners, and the USGS should coordinate to install and maintain a continuous water-quality observatory station in western Moriches Bay near the mouth of the Forge River. For Bay Park, coordination between the Town of Hempstead, Nassau County, the NYSDEC, university partners, and the USGS is needed to maintain existing and ensure proper temporal and spatial monitoring.

WATER gap 9.- Water-quality data are lacking on the ocean side to understand changes within the bay relating to ocean acidification and rising global temperature.

Recommendations to address WATER gap 9.- -Waterquality buoys, similar to those deployed by SoMAS, could be used to monitor $\mathrm{pH}$, water and air temperature, salinity, wave height, and wind at locations near inlets (ocean side).

WATER gap 10.-An understanding of the concentration and loading of microplastics to the water column and bed sediment in the bays is needed.

Recommendations to address WATER gap 10.-Grab samples of water during base-flow and stormflow conditions would help quantify and classify microplastic contamination in the bays and tributaries. Bed sediment grab samples and cores would provide rates of loading to the benthic environment. This effort could be conducted locally by universities in cooperation with the National Oceanic and Atmospheric Administration (NOAA), the U.S. Environmental Protection Agency, and other Federal agencies.

WATER gap 11.-A high-resolution groundwater model for contaminant loading is needed in coastal areas where changes in wastewater infrastructure are being considered.

Recommendations to address WATER gap 11.-Define groundwater loading on local levels based on groundwater contributing areas and traveltimes currently being modeled by the USGS and coupled with loading calculations being developed under the Long Island Nitrogen Action Plan (LINAP). Use the Watershed MVP mapper program and create a decision support tool that also dynamically links with current monitoring resources.

\section{Ecological Resources}

Presentations by PAC members on gaps in ecological resources focused on assessments that are needed of the water quality or biology within the Reserve.

ECOLOGY gap 1.-Effects on ecosystems resulting from the loading of pharmaceuticals, pesticides, and endocrine disruption are not well understood.

Recommendations to address ECOLOGY gap 1.--More research is needed to study the effects of concentrations of contaminants of emerging concern found in the waters and bed sediment of the Reserve on finfish and shellfish pathology. This includes studies that assess seasonal effects and complex mixtures.

ECOLOGY gap 2.-More marine resources data are needed, including data on the population and health of plankton, finfish (such as juvenile eels) and crustaceans. Limited fish seining data are available.

Recommendations to address ECOLOGY gap 2.-NPS conducts only some fish surveys and collects only some biological data through research agreements. These efforts can be coordinated with other organizations interested in supplementing biological or water-quality monitoring. This could be done through notifications from NPS to the Reserve Office, which would then reach out to other groups. For example, a survey of shellfish in the Reserve could be leveraged to collect the following constituents along with count (per standard survey method of the Reserve waters): air temperature, water temperature, water depth, salinity, sediment type, and amount of eelgrass. The following list of tributaries should be surveyed for finfish in marine and freshwater extents: Massapequa Creek, Carlls River, Connetquot River, Carmans River, and Swan River. Studies by SoMAS should be expanded to more fully investigate the biology and chemistry of harmful algal blooms (HABs) and use recommended monitoring data in interpretation.

ECOLOGY gap 3.- Aerial photographs and mapping surveys for SAVs, similar to those done in the Peconic Estuary and Chesapeake Bay, are in need of updating because eelgrass are still disappearing (although some are reappearing or being replanted around the breach).

Recommendations to address ECOLOGY gap 3.--Drones (aerial and submersibles) could be used for bathymetry and SAV purposes. SoMAS, USGS, CERCOM, and The Nature Conservancy (TNC) programs can be expanded to increase the number of fixed stations and buoys to provide greater realtime data coverage. Continuous water temperature profiling and bottom temperature measurements throughout the estuary can relate to SAV health (including loss of eelgrass), as well as other ecological indicators, and flushing dynamics and thus are also needed.

ECOLOGY gap 4.-More research is needed to understand the biological and chemical factors leading to brown tide and other HAB species.

Recommendations to address ECOLOGY gap 4.-Currently, SoMAS research is evaluating the increasing frequency at which HABs are occurring throughout the Reserve (and in particular, Great South Bay and the eastern bays). Along with additional support for SoMAS and other universities in the area, water-quality monitoring (physical constituents, nutrients, water clarity, fertilizers, and pesticides) and sampling by the Suffolk County, the Town of Hempstead, and the USGS could be synchronized with HAB sampling to provide additional data for interpretation. Monitoring strategies presented in the recently released Suffolk County Harmful Algae Bloom Action Plan (Wise, 2017) should be considered as action items 
are implemented to help reduce the number of nuisance and harmful blooms that occur in the waters around Long Island. ECOLOGY gap 5.-Restoration of fish habitat requires consistent monitoring of temperature (throughout the water column), light availability, turbidity, dissolved oxygen, and salinity, and this monitoring is not currently being conducted.

Recommendations to address ECOLOGY gap 5.-The

SCDHS Office of Ecology monitors all bays of the Reserve in Suffolk County and could be coordinated with Cornell Cooperative Extension to collect depth profiles more frequently. Furthermore, Cornell Cooperative Extension could work with SoMAS and TNC to deploy additional buoys and continuous profilers in areas of restoration. The USGS is testing an autonomous underwater vehicle that can map large portions of the bay floors with high-resolution bathymetry and also record temperature, light penetration, and other water-quality constituents. Public notice and outreach regarding the restoration and how it benefits habitat to improve water quality and fishing in the bay should continue on a large scale to build support in the communities, and this outreach should be correlated with the outreach for shellfish-bed and habitat monitoring. The Peconic Estuary Program and Chesapeake Bay eelgrass restoration and monitoring efforts have proven successful (Pickerell and Schott, 2014).

ECOLOGY gap 6.-Horseshoe crab data are collected by several agencies and universities but not coordinated; data are missing for some regions of the Reserve.

Recommendations to address ECOLOGY gap 6-Agreement on standardized methods for horseshoe crab survey and tissue collection should be sought by the NYSDEC, TNC, NPS, Cornell Cooperative Extension, and Molloy College in order to allow data from these organizations to be comparable and used for making management decisions. Coordination among the same groups would allow for sites not being assessed to be visited and improve the overall coverage and density of the horseshoe crab network (some sites within the programs overlap and would provide data quality checks in some cases). Quality assurance can be evaluated to ensure compatibility among programs. A single database for these data would be beneficial.

\section{Estuarine Dynamics}

Presentations by PAC members on estuarine resource gaps focused on hydrodynamics, bathymetry, and sediment flux within the Reserve.

ESTUARY gap 1.-More data are needed to understand effects of sea-level rise on wetlands and marsh islands, updated mapping of Spartina and Phragmites is needed for the entire Reserve, and coordinating aerial light detection and ranging (lidar) surveys with SET site data is needed (and may require additional SET sites for better spatial coverage).

Recommendations to address ESTUARY gap 1 - Correlate high-resolution satellite and aerial photography and infrastructure (land-use) data, wetlands and riparian zone areas, and water-level data collected throughout the Reserve on an annual basis to document changes. Continued collection of aerial vegetation data by the U.S. Fish and Wildlife Service (FWS) would support wetland loss studies. Coordinate a study with high-frequency wave sensors along vulnerable wetlands to determine the extent of wave energy and its effects on erosion.

Additional recommendations to address ESTUARY

gap 1.-Citizen science can be used to survey and groundtruth Spartina and Phragmites in wetlands and correlate resulting data with changes in land use and water chemistry. Coordinate the SET installation and monitoring (including reporting, when-measured, and unit specifications) effort among various groups; consider additional SET marker horizons. A coordinated database of SET data would be useful.

ESTUARY gap 2.-A comprehensive assessment of bedsediment quality across the Reserve is needed because it can reveal information about denitrification in the hyporheic zone and bay bottom, sediment transport, and contaminant loading and persistence.

Recommendations to address ESTUARY gap 2.-The sediment-quality analyses outlined by Woods Hole Group (2010) suggest that bed-sediment-quality data throughout the Reserve are lacking. Research conducted at SoMAS looks at novel sewage and wastewater tracers, particle size, and organic nitrogen and carbon in Hempstead Bay and could be expanded both in space (entire key locations in the Reserve, including bays and tributaries) and constituent type (for example, total inorganic and organic nitrogen and carbon, metals, and radioisotopes for age-dating).

Additional recommendations to address ESTUARY gap 2.-A transect of sediment-quality data across the Great South Bay in areas where chronic low dissolved oxygen is observed would be useful. Coordination among Nassau and Suffolk Counties, the Town of Hempstead, the NYSDEC and the New York State Department of State (NYSDOS), the USGS, NOAA (Mussel Watch), the EPA (National Coastal Condition Assessment program), and SoMAS would be needed to ensure resources and capacities (including split samples when program sample efforts overlap) are in place and management issues discussed prior to establishing a network and sampling.

ESTUARY gap 3.-A better understanding of post-Hurricane Sandy geomorphology of shorelines is needed, especially bayside of the barrier islands, through collection of more data for bathymetry and channel depth, including more nearshore and shallow-water work to survey the bay bottom.

Recommendations to address ESTUARY gap 3.-Apply current data and models to better understand bayside and oceanside geomorphology and sediment transport.

Additional recommendations to address ESTUARY gap 3.-High-resolution bathymetry should be conducted (by boat or autonomous underwater vehicle) to create a baseline for the Reserve bottom ahead of the next major coastal storm that redistributes large volumes of sediment. This could be conducted simultaneously with SAV and shellfish surveys (either hyperspectral or visual) and updated after major 
dredging operations or coastal storms that cause substantial sediment redistribution.

ESTUARY gap 4.-A better understanding is needed of sediment flux from tributaries to bays, sediment deposition and transport across the bay bottom, and how distribution relates to legacy contamination.

Recommendations to address ESTUARY gap 4.- Sediment transport, current-velocity, and geomorphic profile data should be collected in the Carlls River and Carmans River watersheds initially and then in other larger tributaries as needed.

ESTUARY gap 5.-Marsh area and sediment transport data should be collected on a regular basis to establish long-term trends in changes in geomorphology and wetland loss (for example, marsh conversion from high marsh to low marsh is not keeping up with changes in water levels in the bays). Automated measuring of sediment flux through inlets and tracking of sea-level rise would inform an understanding of net transport to or from the estuary. The extent to which boats and other watercraft affect marsh islands and shoreline resiliency is not well known. Correlating storm effects with the root depth and health of vegetation is important. A loss of native grasses such as Spartina resulting in decreasing arthropods (particularly in the Bay Park area) has been observed.

Recommendations to address ESTUARY gap 5.-Comparisons of marsh areas and grasses (for example, Spartina and Phragmites) that were conducted for the New England Interstate Water Pollution Control Commission by using aerial surveys from the 1974 and the 2005 and 2008 fly-overs (Cameron Engineering \& Associates, LLP., 2015) accounted for roughly 11 percent of marsh loss in the Reserve. Decadalscale updates to these surveys with the most up-to-date remote sensing technology will allow for consistent monitoring of progress towards addressing the loss of marshlands (NYSDEC, n.d.[d]) and should be incorporated into updated landuse data and trends in water-quality data to provide updates on the restoration effort.

Additional SETs may be needed since marshes are being affected by rising sea level. Coordinate the SET installation and monitoring (including reporting, when-measured, and unit specifications) among the NPS, TNC, the Shinnecock Tribe, and the USGS and consider additional SETs at the following stations to supplement the current network: select marsh islands of Middle Bay and East Bay, barrier island marsh of South Oyster Bay, marsh island adjacent to Fire Island Inlet, and marsh in the southern part of the Shinnecock Tribal Lands peninsula.

High-frequency wave sensors could be deployed along vulnerable wetlands to determine the extent of wave energy and its effects on erosion.

ESTUARY gap 6.-A better understanding of the ecological and physical (such as flooding, flushing, and inundation) effects of the breach at Old Inlet is needed.

Recommendations to address ESTUARY gap 6.-Continuous water-level and water-quality monitoring at the inlet via a buoy that measures turbidity, water temperature, salinity, and fluorescence is needed to support the existing LIShore Bellport Station (Bellport Bay; located across the breach).

Additional recommendations to address ESTUARY

gap 6.-A focused evaluation of ecological resources in the bays and tributaries adjacent to the breach could be conducted from data from the estuary-wide studies of algae, finfish, and macroinvertebrates.

ESTUARY gap 7.-More studies are needed to understand whether marshes in the Reserve act as a nitrogen source or sink.

Recommendations to address ESTUARY gap 7.-Detailed nutrient and microbial analysis of sediment and pore water under laboratory conditions and in situ could be coordinated between SoMAS, the Town of Hempstead, the SCDHS, and Suffolk County Vector Control to better understand the fate of nitrogen entering marshes through groundwater seepage, from the water column, and from atmospheric deposition.

\section{Atmospheric Resources}

Presentations by PAC members on the gap in atmospheric resources focused on understanding how air quality can affect the water quality and ecology of the Reserve.

AIR gap 1.-Air resources should be looked at more closely, including levels of nitrogen dioxide and other pollutants (for example, ozone, mercury, and particulates) and the extent of deposition to the waters of the Reserve.

Recommendations to address AIR gap 1.-The NYSDEC should expand the ambient air monitoring network to include additional sites along the south shore.

Additional recommendations to address AIR gap 1.-A station similar to the National Atmospheric Deposition Program's wet weather station in Southold should be established somewhere mid-island and monitor for dry- and wet-weather deposition and concentration of contaminants, including acid rain $(\mathrm{pH})$, ozone, and nitrogen dioxide.

\section{Infrastructure and Land Use}

Specific monitoring of infrastructure relative to water and ecological resources was presented by members of the PAC as a gap in two ways.

INFRASTRUCTURE gap 1.-High-resolution mapping of all storm drains, sewer lines, storm sewer lines, and outfalls, as well as cesspool and septic density in unsewered areas, is needed throughout the Reserve; a complete dataset could, among other uses, provide inputs for source tracking models.

Recommendations to address INFRASTRUCTURE gap 1.- The 2008 Stormwater Infrastructure Mapping Inventory and Assessment (New York State Department of State Office of Planning and Development South Shore Estuary Reserve Council, 2008) identified the extent to which outfalls and storm sewers were documented by government agencies within the Reserve. The report found varying degrees of accuracy, detail, and completeness and made recommendations 
for filling the gaps among the 39 municipalities responsible for handling stormwater. These recommendations should be followed, with data being ultimately housed on the New York State Geographic Information Systems Clearinghouse, which exists to host all relevant GIS data within the State. Detailed coverages of sewered areas exist through the Suffolk County Division of Planning and Environment; identification of homes that are not hooked up in both Counties would be helpful. Additional mapping efforts should provide layers for the Reserve water-quality mapper. Continue to support Cornell Cooperative Extension mapping effort, and determine what towns and counties (some involved in localized work done as part of the Comprehensive Management Plan development for select watersheds) still need their stormwater infrastructure mapped (the mapping would be done by citizen scientists provided with standardized GPS units and basic training [by boat and land]). The Reserve Office could help facilitate the move to a single database for infrastructure projects (including best management practices [BMPs] and green infrastructure) within the Reserve, and the database could include project specifics along with any relevant water-quality monitoring data from before and after the project and associated with affected waters.

INFRASTRUCTURE gap 2.-More detailed and current mapping of zoning developments throughout the Reserve is needed. Land-use maps were updated every 5 years (latest version released in 2012); updates are no longer done because of high cost and loss of staffing.

Recommendations to address INFRASTRUCTURE gap 2.- Revised versions of the current land-use maps are needed and should be coordinated between Nassau and Suffolk Counties and possibly funded through a State grant. These land-use data will be used for groundwater and watershed modeling and decision tools. Attributes for digital GIS maps should include wastewater management (specifically cesspool, septic, sewered, and stormwater) and water supply.

\section{General and Coordination Recommendations From the Project Advisory Committee}

A number of management plans have been developed for groundwater and surface waters that include some or all of the Reserve (table 2; appendix 3). Thirty of these plans have been funded by the New York State Department of State since 2000 to study the ecological health and potential for improvements in the Reserve. These plans outline different issues facing the Reserve and propose which organization is most capable to address the issue and how it could do so. The plans tend to have similar formats, with only subtle differences, for describing issues that actually relate to the entire Reserve. Members of the Project Advisory Committee have emphasized the importance of following through on implementing recommendations in comprehensive management plans in a coordinated and mutually beneficial manner to maximize efficiency among the organizations performing the tasks.

This section summarizes recommendations of the PAC and is intended to help synchronize water-quality and ecological monitoring throughout the Reserve in order to meet management objectives and address issues. Recommendations presented here are a compilation of comments recorded at the PAC meetings and workshop, as well as meetings with researchers and representatives of organizations with a vested interest in the Reserve. These recommendations are programmatic and overarching rather than specific to constituent or monitoring type, and generally they address the management issues raised by stakeholders and summarized in the introduction and in table 3.

\section{General Recommendations of the Project Advisory Committee}

Although addressing gaps in monitoring and data collection throughout the Reserve (see the section "Data Gaps and Specific Recommendations") can be a relatively straightforward effort, coordinating efforts around projects that focus on resources and resiliency, developing and utilizing existing tools for assessing water quality and ecological health, and engaging community groups to help improve awareness of the resources is not always easy. Management issues outlined in table 3 often overlap spatially and may require similar data and quality assurances to be addressed. The PAC has made the following general recommendations that can help coordinate the collection and use of data from current and proposed programs:

1. Standardization of data and metadata

2. Expansion and enhancement of real-time water-quality monitoring

3. Coordination with citizen science organizations

4. Updating of municipal-land-use maps

5. Expansion of remote sensing technology

6. Use of advanced hydrodynamic models

7. Use of a decision support tool for understanding changes to loading of nutrients

8. Implementation of a network of rapid-deployment waterquality monitors

9. Coordination of groundwater-quality sampling

10. Monitoring of preserved lands through expansion of the Community Preservation Fund

11. Investigation of effects of moving the Bay Park Sewage Treatment Plant outfall 
12. Enhanced documentation of long-term water-quality changes

Details for each recommendation follow:

1. Standardizing data across monitoring programs and studies would maximize data usage and availability for model input (that is, combining south shore environmental monitoring data with those from the Long Island Sound Study [LISS] and the Peconic Estuary Program [PEP], including documentation of standardized procedures and analytic results, and storing the data in a centralized location). This includes data that are collected outside the Reserve but are relevant to water quality and the ecological health of Long Island. Specific examples of data standardization include the following:

A. Estuarine water-quality data should be analyzed and stored by following consistent methods agreed upon by all stakeholders, with U.S. Environmental Protection Agency-approved laboratory methods used whenever possible. Consistent field protocols (with documentation) are also suggested. Current methods used by the Suffolk County Department of Health Services, Nassau County Department of Health, and Town of Hempstead are listed in table 4 (in back of report).

B. Metadata (information about the data) are important for utilization of data and should be documented properly. It is recommended that principal investigators of all monitoring programs and studies done in the Reserve provide metadata to the NYSDOS or the New York State Department of Environmental Conservation for archiving in a South Shore Estuary Reserve Water Resources database and mapper. By supplying metadata, which would include a link to a publicly accessible database, results would be more easily shared. Potential gaps in monitoring would be identified so that proposals could be tailored and additional partners involved. Historical data may be available in an older standard, and conversion to the latest units would be ideal (such as converting the elevation datum for water-level measurements from the National Geodetic Vertical Datum of 1929 [NGVD 29] to the North American Vertical Datum of 1988 [NAVD 88]). Any conversion performed on data should be noted, along with the conversion tool used, in the metadata. (Data that are not subject to public release because of proprietary or legal obligations would only include principal stakeholder contact information, which would serve as the source of data in the metadata provided.)

C. Storage of data collected for a monitoring program or study in a manner allowing for researchers and stakeholders to access and use findings from previous programs is critical to the efficiency and conti- nuity of studying the Reserve. Long-term datasets are valuable for historical context and should be preserved after a project ends. Databases maintained by the Federal government for the dissemination and preservation of environmental data are available at no charge. Two in particular, EPA Storage and Retrieval (through the Water Quality Portal) and U.S. Geological Survey ScienceBase, provide efficient mechanisms by which data, metadata, and relevant ancillary information can be shared with the public and archived in perpetuity. In addition to data storage, a new tool being developed by the USGS will be made available to other agencies and municipalities for the digitization of paper records containing data in a standard template (for example, old hand-written field forms) in the near future (Wippich, 2012). This online tool will allow records to be scanned and electronically formatted to allow users to enter the values in text fields representing the fields on the paper form - these values are then stored in a database and provided to the user.

D. Water-level data recorded in reference to NGVD 29 should be converted to NAVD 88 and standardized in the future. NOAA provides a datum converter, available at https://www.ngs.noaa.gov/cgi-bin/ VERTCON/vert_con.prl.

2. Additional real-time water-quality monitoring is needed in the bays and tributaries of the Reserve. Real-time monitoring stations are costly, and those established as part of research projects can often be maintained with operations and maintenance funding that is a small fraction of the cost to establish the station. In situations where ongoing data collection would be valuable for management efforts, a streamlined path to providing continued funding for these stations should be in place. Current and recently approved locations and their respective constituents can be found on the Coordinated Water Resources Monitoring Strategy mapper.

A. The following locations are recommended for realtime tide (stage) and water-quality monitoring and could be developed by the Stony Brook University School of Marine and Atmospheric Sciences and (or) the USGS; these could also serve as early-warning stations in the event of a coastal storm: Forge River, Robert Moses Bridge, Heady Creek, Tiana Bay, Reynolds Channel (buoys to determine flow and basic constituents), and additional locations in the Great South Bay. (The USGS is currently [2017] working with State and Federal partners to install tide gages in Shinnecock Bay and Moriches Bay.)

B. Additional constituents, such as nutrient loading (nitrate) and water clarity (turbidity and [or] photosynthetically active radiation), to the current surface 
water-quality network are recommended for existing sites because they would support management decisions and fulfill recommendations made in other management and action plans already in place. Support for these constituents could come from TNC and (or) the NYSDEC to supplement data collection in areas of seagrass restoration efforts.

3. Coordinate research and agency monitoring programs with citizen science organizations to establish a Reserve report card and support total maximum daily load development.

A. Researchers from the National Oceanic Atmospheric Administration and the University of Maryland Center for Environmental Science have developed a reporting system that uses six core trophic state indicators to grade the conditions of an estuary with respect to ecological health (Bricker and others, 2007; EcoCheck, 2011). If the reporting system were adopted for use in the Reserve, conditions would be graded on the basis of physical (water clarity and submerged aquatic vegetation survey) and chemical (dissolved oxygen, water temperature, nitrogen and phosphorus, and chlorophyll $a$ ) data and the availability of data. The waters should be divided into segments such that each can be monitored at specific locations where changes in practice or infrastructure can be made. Additional constituents monitored are those identified by management plans and those affected by a potential change (for example, stormwater runoff being diverted to bioswales would be evaluated for major ions and trace metals, nutrients, and fecal indicator bacteria). Sampling regimes should be created on the basis of factors outlined in EcoCheck (2011), and the shared sampling effort should be coordinated by the Reserve Office. This reporting system would be a simplified graphical product to raise community awareness and help describe the issues identified by management plans in an easy-to-understand way.

B. Many tributaries within the Reserve are listed on the 303(d) list of impaired waters and TMDLs. Citizen scientists could conduct supplemental nutrient and pathogen monitoring to support the creation of a TMDL. It is important to synchronize current monitoring programs and establish new stations in areas where nitrogen and pathogen sources are known but not assessed (for example, storm drain outfalls). Following an established quality assurance project plan (QAPP) for the collection of water samples, volunteers would submit samples through an agreement with either a private lab (similar to the monitoring program established by the Friends of the Bay (Oyster Bay) or a local academic institute. Further, handheld equipment, such as spectrofluorometers, could be used onsite to determine various forms of nitrogen and phosphorus - several analytical test kits for spectrofluorometers are available that have been approved by the EPA - and coliform concentrations (for example, the Colifast field meter).

4. Municipal-land-use maps should be updated every five years because changes in development density, development type, and land preservation directly affect the ecological health of the Reserve. Resources at the town and county levels have been strained, which has led to fewer revisions to land-use and other maps and products. Coordinating the development and storage of a GIS and remote sensing repository (New York State GIS clearinghouse, for example [http://opdgig.dos.ny.gov/\#/home]) for Reserve-related data could be achieved by working with university professors and nonprofit organizations. Professors from Hofstra University, Molloy College, and Adelphi University have indicated their organizations have the capacity to work together and with the towns and counties to update and improve land-use maps (or coverages) and incorporate other infrastructure products (for example, locations of onsite wastewater treatment systems) that are necessary for proper planning around sensitive and impaired waters and in contributing areas. These updated maps are of particular importance in areas that expect major redevelopment that would change the current wastewater footprint of an area. Cataloging the locations of stormwater BMPs that include green infrastructure in the watersheds within the Reserve is another area for towns and counties to collaborate with universities, as each municipality typically has its own records and ways in which the projects are monitored for permit compliance and efficiency.

5. Remote sensing technology, such as lidar topobathy, aerial fluorescence, and unmanned aircraft and submersibles (drones), continues to advance in accuracy and precision and can provide large-scale coverage that is needed for assessing system-wide processes and thus should be used to collect data in conjunction with relevant projects as often as permitted to allow for continuous updates to the dataset. These data should be cataloged by the Reserve Office, made available through the New York State GIS Clearinghouse, and referenced by the data. gov website so they are available to other researchers and organizations. Although costs can be high, the data these tools provide allow for estuary-wide surveys of shoreline movement, vegetation, and bathymetry that inform models and planning efforts. It is recommended that the shoreline monitoring of sediment transport and mapping of topography be continued through local agreements with organizations that monitor the Reserve and the FWS and NOAA. Unprotected shorelines (including along streams), wetlands, and marsh island extents should be monitored jointly by towns, counties, and nonprofit organizations for changes, such as marsh 
loss or accretion, and effects of sea-level rise. Further, monitoring of aquatic vegetation (such as eelgrass and Ruppia maritima [widgeongrass]) through aerial imagery (collected by the FWS) should be coordinated with seabed surveys and SET data collections to calibrate the remote sensing equipment, inform subsequent models, and maintain a consistent dataset. (SAV data are a trophic state indicator and required to create the Reserve report card.) The effort can be coordinated through the Reserve Office, which could provide opportunities for researchers and other stakeholders to request an opportunity to collaborate during a data collection period. Field verification of remote data should also be coordinated. Specific recommendations include the following:

A. Satellite-acquired bathymetric data do not provide the resolution needed to track the low sedimentation rates of the Reserve bays. Therefore, autonomous underwater vehicles or boat-mounted sensors are recommended for detailed surveys and should be deployed in segments throughout the Reserve.

B. Aerial imagery should be acquired every 3-5 years and after a major coastal storm that causes considerable sediment redistribution or infrastructure damage.

C. Invasive species surveys conducted by municipalities, citizen scientists, and other organizations should be correlated with remote imagery.

6. Advanced hydrodynamic models are available to help inform management decisions related to contaminant loading to the bays and groundwater under a variety of conditions and could be employed to improve understanding of contaminant loading to the Reserve. Models applicable to the Reserve watershed include the updated USGS groundwater traveltime model, stormwater loading models such as SPARROW (https://water.usgs.gov/ nawqa/sparrow/), EPA Virtual Beach (https:/www.epa. gov/exposure-assessment-models/virtual-beach-vb), and numerical models for circulation and water movement throughout the estuary. Data should be collected for input conditions to support model development, such as NOAA bathymetry, shoreline dimensions, tributary flow data, and a sufficient water-quality dataset. As the models being proposed for groundwater flow and nutrient loading are island wide, the NYSDEC and the NYSDOS intend to evaluate the current groundwater and surfacewater sampling programs to be sure the necessary data are being collected at the resolution, frequency, and accuracy to account for contributions, particularly when changes are implemented.

7. New York State should adopt a decision support tool for use with groundwater and nutrient loading data collected and modeled in Long Island. One option is Watershed MVP (http://www.watershedmvp.org), created by the
Cape Cod Commission, which has been offered to New York State. This product would be a valuable interface for visualizing changes to land practices concerning nutrient loading (wastewater infrastructure improvements, changes in fertilizer application, and stormwater runoff diversion). A USGS model for delineating refined areas contributing to groundwater recharge (currently under development) would be used as the backbone of the hydrodynamics of groundwater flow to the tributaries and bays. Also needed are nutrient loading and assessment models scheduled to be developed under the Long Island Nitrogen Action Plan (LINAP). In order to support these nutrient models, surface-water- and groundwater-quality monitoring data are needed. As is being proposed through the LINAP, constituents necessary to inform the models used by the tool should be determined by forming a committee and assessing what needs to be collected and by which organizations.

8. A network of rapid-deployment water-quality monitors for responding ahead of a major coastal storm would provide emergency responders with data needed to protect public health and would enable testing of recently developed particle-transport models (Swanson, 2013) and developing new models. This network could leverage the USGS Surge, Wave, and Tide Hydrodynamics (SWaTH) network (https://water.usgs.gov/floods/swath/) locations. Collaboration on the Federal, State, and local levels could help supplement the lack of permanent, continuous water-quality monitoring to assess the release of sewage, runoff, and other contaminants to the bays and tributaries. Little is known of the short- and long-term effects these releases had on the Reserve ecosystem in the aftermath of Hurricane Sandy.

9. As Suffolk County legislation moves to approve wastewater-treatment upgrades (both onsite and community), coordinating the groundwater-quality sampling is recommended in order to develop trends in the upper glacial and Magothy aquifers, as well as the bays and tributaries of the Reserve. Advanced onsite wastewater systems installed in priority areas within the Reserve boundaries (Suffolk County Government, 2015), particularly over a large area, could result in major changes to the concentration of nutrients loading to the Reserve (Monti and Scorca, 2003). Developing a baseline at this early stage is critical to understanding what works in Long Island soils and hydrology when before-and-after installation comparisons are made. Data collected by advanced onsite wastewater-treatment-system vendors and service providers should be centralized in a database and made available publicly for calibrating inputs to models and comparing removal efficiencies among systems and across the region. Current monitoring that provides a baseline includes the USGS groundwater- and surface-water-quality network, SCDHS Office of Water Resources, SCDHS Office of Ecology sampling, Nassau 
County Department of Health sampling, and Town of Hempstead sampling.

10. The Community Preservation Fund should be instated throughout Long Island as it has been successful in preserving open spaces within the Peconic Estuary and has recently (2016) been approved by voters to use some of its funds to assess water quality. A similar transfer tax for public purchases of south shore properties has been attempted in the western towns of the Reserve (Babylon, Islip, and Brookhaven), but the legislation must still pass a referendum. Retaining lands and keeping nature preserves open provides protected habitat, and restoration of wetlands provides buffering for storm surge and increased resiliency over hardened structures such as bulkheads. Preserved lands would also be suitable for research and water-quality and ecological monitoring with respect to understanding implications of conservation and reclamation of developed land and protection of groundwater and surface waters.

11. Effects of diverting the Bay Park and Long Beach sewage treatment plants discharge to the Cedar Creek Water Pollution Control Plant line (and thereby increasing discharge from the current ocean outfall) need to be investigated. Rigorous baseline data (for example, $\mathrm{pH}$, water temperature, nitrogen [inorganic species as well as total inorganic and total organic] concentration, and Ulva surveys [within the bays]) should be collected within Reynolds Channel and the bays, as well as at the proposed current ocean outfall for Cedar Creek, before modifications are made and maintained after construction to track potential effects on water quality in the Reserve through time. This sampling effort would require commitments from the Town of Hempstead, Nassau County, the NYSDEC, and the EPA, and coordination with the Reserve Office and other researchers would be important.

12. A unified system to document long-term water-quality improvements resulting from wastewater-infrastructure upgrades, BMP and stormwater mitigation, and coastal reconstruction and resiliency projects is needed for the Reserve. In particular, a website with interactive mapper to display current infrastructure projects (with metadata to include agencies involved, type of grant, and waterways affected) and the respective monitoring locations and types is needed. A commitment to periodic monitoring should be part of future grant requirements for infrastructure and coastal improvements, and a centralized repository at the State or Federal level should hold results.

\section{Recommendations for Stakeholder Coordination by the Project Advisory Committee}

Consistent documentation of resource monitoring and other scientific activities within the Reserve by the Reserve Office would improve coordination and efficiency and address management issues presented in previous plans and strategies. The Reserve Office should consider reestablishing its role as the main point of coordination for groups conducting volunteer monitoring as a way of assisting agencies or other organizations to enhance current monitoring programs. The Reserve Office could provide information and standardized QAPPs, coordinate monitoring among groups to maximize efficiency, and help with the EPA citizen science equipment loaner program. This monitoring is needed in areas the towns and counties are unable to sample on a consistent basis and can help fulfill recommendations made in the 2000 CWRMS (that samples be collected at each tributary mouth and along each bay and inlet). A full-time coordinator would allow for projects to be better synchronized with current management needs and with each other and would assume the following responsibilities:

- Establish regular meetings of the Reserve Council and subcommittees to address all the issues, concerns, research gaps that were identified in this CWRMS and other management plans. Working group subcommittees should be established to focus on specific issues, for example sediment and a horseshoe crab permit system.

- Maintain a dynamic list of stakeholders and researchers in concert with the Reserve Council and request routine updates (annually through online surveys) that capture the current status of monitoring, data interpretation and archival, coordination efforts with other stakeholders, and future plans - a forum for stakeholders could be used.

- Develop a timeline for revision to the CWRMS.

- Determine costs needed to establish a monitoring committee. The Nassau County Soil and Water Conservation District could conduct outreach for municipalities with municipal separate storm sewer systems (MS4) through committee funding (north shore committees have worked well to meet MS4 regulations when budgets are limited). Peconic Estuary now has a Protection Committee with members representing towns, Suffolk County, and villages.

- Assist citizen scientists, school groups, and other nonprofit organizations collecting useful data by providing resources for sample collection and monitoring, as well as assisting the creation of quality assurance and quality control (QA/QC) protocols consistent with the level of scrutiny the data will receive. 
- Look for ways to leverage monitoring already being conducted (or that is planned) by municipalities, academia, volunteers, and the Soil and Water Conservation Districts and apply them to existing management plans while working with the communities to garner support and assess opportunities for citizen science to fill gaps.

- Conduct public outreach by presenting a summary of the data collected within the Reserve and how they coalesce into usable information.

- Hold workshops for citizen science groups on topics such as water-quality monitoring equipment, and provide technical advice on the way in which a monitoring program should be set up. The workshops should emphasize standardizing data collection and maintaining proper field and calibration notes.

- Assist and encourage those collecting data to input their data into dedicated citizen science databases or a Federal repository (such as Water Quality Portal or USGS ScienceBase) as a way of archiving the record and ensuring the data are available to the public via the internet and the CWRMS mapper.

- Distribute resources, such as templates for necessary documents (for example, QAPPs), report and data entry forms, and applications for equipment loaner programs.

- Encourage and assist in opening up dialogue concerning issues, monitoring, and opportunities among Reserve stakeholders. This could be done through a consortium of academics that would review current data on a regular basis and generate reports on the health of the Reserve in concert with the report cards. More presentations and a venue for discussion of Reserve issues, monitoring, and opportunities would help raise awareness in the communities and with politicians. The consortium needs to be independent of policymakers and yet integrative into oversight by regulatory agencies.

- Maintain an up-to-date list of opportunities (State and Federal) for grants related to the management topic at hand and work to coordinate monitoring among scientists, researchers and students, as well as bringing in government agencies (Federal, State, Tribal, town and village) to help bolster the data collection effort and support effective grant proposals.

\section{Coordinated Water Resources Monitoring Strategy Website}

The Coordinated Water Resources Strategy website (http://www.sserwaterquality.us/) was created to provide information about current and upcoming water-quality and ecological monitoring in the Reserve. Its main purpose is to host an interactive mapper through the duration of the project by which stakeholders and interested parties can assess the extent of monitoring programs and identify potential gaps in the current programs from a geographical perspective. A brief description of the coordination effort and the final version of this report are available from the main "CWRMS" web page. Monitoring programs are displayed with additional information on the "Data" web page and through toggling and querying on the mapper. The "References" web page lists relevant documents, such as management reports, action plans, and research papers, in a searchable format. A list of Reserve stakeholders that participated in the development of the 2016-17 CWRMS as part of the Project Advisory Committee is provided on the "Stakeholder" web page. A forum that was established for PAC members to share information and post documents and data for dissemination on the main CWRMS website is reached by clicking on "Login"- this function is limited in use to PAC members and will not be preserved beyond the end of this project unless the scope is expanded to include additional estuaries in Long Island (see the report sections "General and Coordination Recommendations From the Project Advisory Committee" and "Potential Expansion").

Currently (2017), the CWRMS website resides on a thirdparty server and is operated and maintained by the USGS. The USGS ScienceBase entry (https://doi.org/10.5066/F7JQ0Z46) for this project will ultimately host the resources currently available on the CWRMS website, as well as links to download this report and associated tables, the interactive mapper, and the information associated with the mapper and report. Functions of the website and the databases that serve the mapper will be preserved, as the coding has been developed by the USGS and is open source. The entire website conforms to the Rehabilitation Act of 1973 and is 508 compliant (U.S. Access Board, 2000). Current and past news related to water-quality issues in the Reserve available on the "SSER" web page are available through the Reserve Council website (http://www. dos.ny.gov/opd/sser/).

\section{Resources and Data}

Documents related to water and biological studies done within the Reserve over the past 16 years have been compiled to supplement the resources referenced in the 2000 CWRMS report. Those references, along with the more recent 
comprehensive management plans of watersheds and bays, updated study and model information, and climate change and resiliency plans, are referenced in the CWRMS report and are available for download. Links to websites are also provided, and the database can be sorted and queried to help users find resources by topic, waterbody, or funding agency.

The "Data" web page provides information available on the interactive mapper in a tabular format that can be sorted and searched. Metadata provided by organizations conducting water-quality and ecological monitoring programs, wildlife studies, and infrastructure are important for understanding ecosystem health and where water-quality monitoring occurs (such as outfall locations of storm drains and New York State Department of Environmental Conservation shellfish classification areas). Information on data ownership and contact information is available. Tables displayed that result from sorting and queries can be downloaded. If datasets were uploaded by an organization for dissemination (because the data would not otherwise be available publicly, for example), those data are available for download directly (with the disclaimer that data were not collected or evaluated by the NYSDOS or USGS and these agencies take no responsibility for their quality or use).

\section{Mapper}

The Reserve mapper aggregates available monitoring, study, and resiliency information from government agencies, academic institutions, nonprofit organizations, and citizen scientists and displays basic information about the type of monitoring, constituents collected, and responsible party contact or link by which data can be requested or downloaded (fig. 5). The mapper and metadata tables are meant to be dynamic and continuously updated on the basis of changes in monitoring programs (for example, addition of constituents measured) and implementation of new studies or monitoring. In order for these continuous updates to be successful, the Reserve Office should be provided with updated versions of the spreadsheets used in the initial information-gathering for this report. The annual update request sent to the Reserve Office could be enhanced by use of this spreadsheet through the use of an online form (as suggested in the section "Quality Assurance and Quality Control, Metadata, and Data Archives").

\section{Metadata Attributes}

As presented in the section "Quality Assurance and Quality Control, Metadata, and Data Archives," monitoring resources can be divided by class, type, and frequency of sampling. The mapper defaults to displaying the data categorized by sample environment (class); that is, water (surface water, groundwater, and sediment) and biological (wildlife surveys, HABs, pathogens), with subsets for each being represented by different point shapes and colors. Subcategories represent details of a program, such as frequency of sample collection (real-time or discrete measurements, for example) and constituent class (such as water-quality samples collected for physical constituents and pesticide analysis). Presentation of the metadata through information boxes has been standardized across classes to include only attributes relevant to understanding the name of the study or program, the type of data available, the quality of the data (QA/QC; if applicable), and the location of each site (coordinates with respective datum). Standardizing these fields allows for information within each class and type to be filtered and thus enables the mapper to function properly.

\section{Functionality}

The mapper uses the Esri ArcGIS platform, which has been customized by using Java script to allow for integration and searchability of the metadata provided. Points that represent monitoring programs (water-quality or ecological) or studies are generated from an array of tables extracted from the South Shore Estuary Reserve CWRMS monitoring network database. Displaying points specific to a search or query is done by filtering select criteria within a given subset of the metadata. Information provided by PAC members was categorized on the basis of several attributes: resource type (environmental data, infrastructure details, geographic coverages, or resiliency plans), status of program (historical record or ongoing), and responsible organization (data or project owner). Attribute tables that display when a point or layer is selected on the mapper have been standardized on the basis of the resource type to provide the same type of information needed to compare monitoring programs, types of infrastructure and associated environmental impact data (for example, State Pollutant Discharge Elimination System permits), ecological assessments or studies, source of information (that is, the owner), and contact for obtaining data or GIS layers. The Reserve CWRMS monitoring network database is served through the website host, with copies backed up on the USGS server.

Polygons are presented through a service from the USGS ScienceBase, are generated from existing layers, and are incorporated into the search and navigation functions. These layers can be toggled on and off and include links to associated information on the USGS server. Search functions are possible but limited in the service-generated layers. Navigation of the mapper includes functions similar to many of the popular online mappers (zoom, pan, change base layer) and allows for search by hydrological unit code (base 12; HUC12), address, and waterbody.

\section{Potential Expansion}

The process by which program and study information within the Reserve was gathered from stakeholders can be replicated for the other two estuaries around Long IslandPeconic Estuary and Long Island Sound. One component of 


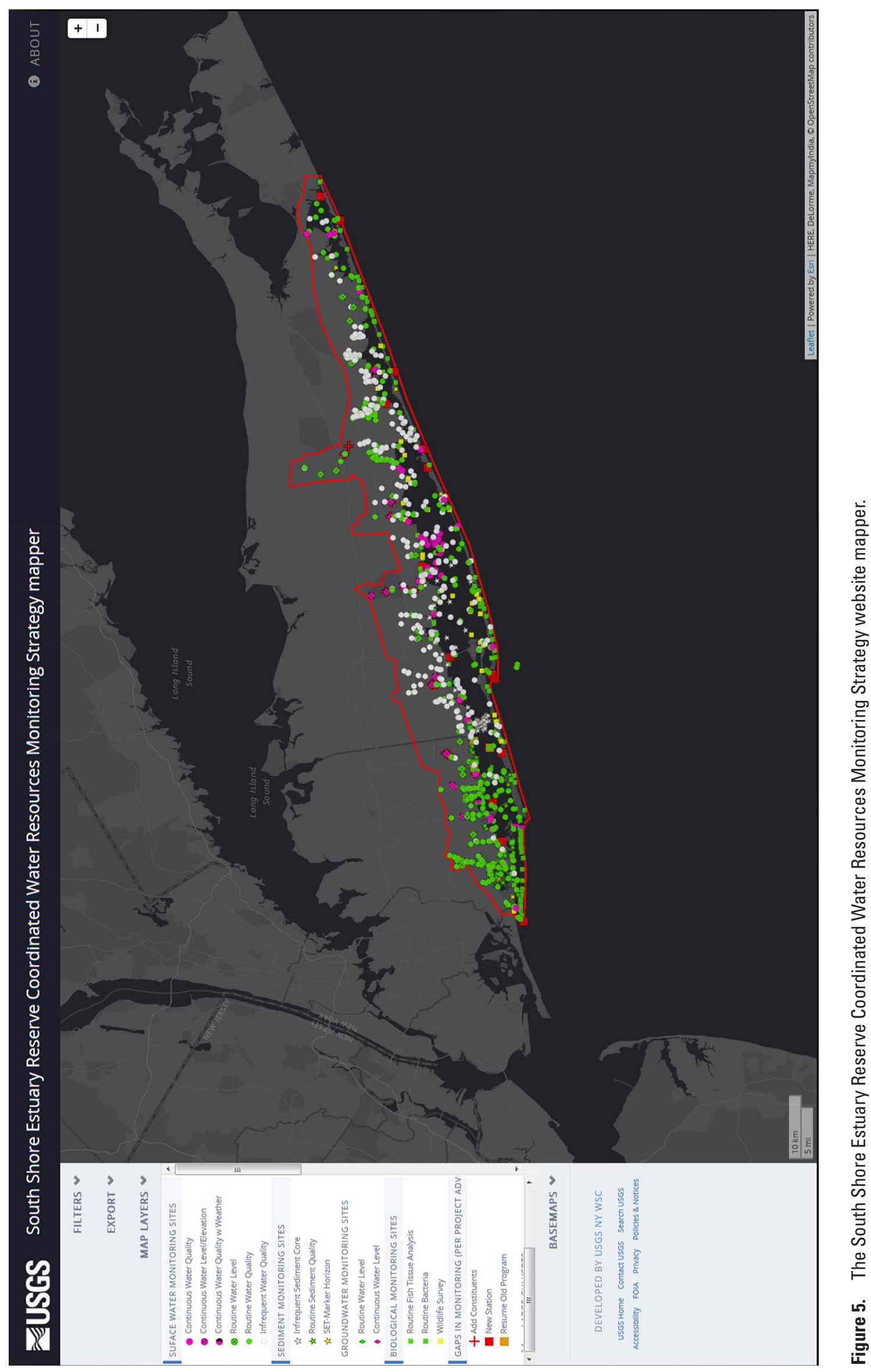


the NYSDEC LINAP is to assemble all available data for use in future models that rely on new and historical data for nutrient concentrations assessed in surface waters, in groundwater, and from loading models. Simple, standardized templates are directly incorporated into the mapper and data features on the website, and the USGS has the capacity to incorporate additional programs, watersheds, and data layers on the basis of LINAP and stakeholder needs.

\section{References Cited}

A Day in the Life, [n.d.], List of participating rivers and sites: A Day in the Life website, accessed April 10, 2017, at http://www.portaltodiscovery.org/aday/sites.htm.

AKRF Inc., 2015, Framework for the future-Suffolk County comprehensive master plan 2035: Hauppauge, N.Y., Suffolk County Department of Economic Development and Planning, $692 \mathrm{p}$.

Aretxabaleta, A.L., Butman, Bradford, and Ganju, N.K., 2014, Water level response in back-barrier bays unchanged following Hurricane Sandy: Geophysical Research Letters, v. 41, no. 9, p 3163-3171.

Arthur, Jody, 2015, General guidance for the Office of Water Quality external data framework: Indiana Department of Environmental Management, 11 p., accessed June 2016 at http://in.gov/idem/cleanwater/2485.htm.

Barlow, P.M., 2003, Ground water in freshwater-saltwater environments of the Atlantic coast: U.S. Geological Survey Circular 1262, 121 p., accessed January 31, 2017, at https://pubs.usgs.gov/circ/2003/circ1262/.

Barlow, P.M., and Leake, S.A., 2012, Streamflow depletion by wells-Understanding and managing the effects of groundwater pumping on streamflow: U.S. Geological Survey Circular 1376, 84 p. [Also available at http://pubs.usgs.gov/ circ/1376/].

Beck, A.J., Rapaglia, J.P., Cochran, J.K., Bokuniewicz, H.J., and Yang, Suhui, 2007, Submarine groundwater discharge to Great South Bay, NY, estimated using Ra isotopes: Marine Chemistry, v. 109, p. 279-291, accessed January 31, 2017, at http://moritz.botany.ut.ee/ olli/ eutrsem/Beck08.pdf.

Board of Trustees of the Town of Southampton, 2001, Town of Southampton Marine Resources Protection and Management Plan-Moriches Bay, Shinnecock Bay and Mecox Bay: Southampton, N.Y., Town of Southampton, 85 p.
Boehm, A.B., and Sassoubre, L.M., 2014, Enterococci as indicators of environmental fecal contamination in Gilmore, M.S., Clewell, D.B., Ike, Y., and others, eds., Enterococci-From commensals to leading causes of drug resistant infection: Boston, Mass., Massachusetts Eye and Ear Infirmary, 21 p., accessed January 31, 2017, at https://www.ncbi.nlm.nih.gov/books/NBK190421.

Branca, B.A., and Focazio, P.C., 2009, Harmful algal blooms plague Long Island waters: New York Sea Grant web page, accessed April 10, 2017, at http://www.seagrant.sunysb.edu/ Images/Uploads/PDFs/themeareas/CComm-Habitat/BTRI/ Fall09-HABs.pdf.

Bricker, S.B., Longstaff, B.J., Dennison, W.C., Jones, A.B., Boicourt, K., Wicks, C., and Woerner, J., 2007, Effects of nutrient enrichment in the nation's estuaries-A decade of change: Harmful Algae, v. 8, no. 1, p. 21-32, 168 p., accessed January 31, 2017, at http://www.sciencedirect. com/science/article/pii/S1568988308001182.

Brown, Marshall, 2013, The breach report, 8-13-13-So what are we to call it? The breach, the old inlet, the new inlet?: Save the Great South Bay blog, August 13, 2013, accessed April 10, 2017, at https://savethegreatsouthbay.org/tag/ the-new-inlet/.

Cameron Engineering \& Associates, LLP., 2015, Long Island wetlands trends analysis: New England Interstate Water Pollution Control Commission, 131 p. with appendixes, accessed January 31, 2017, at http://www.dec.ny.gov/ lands/5113.html.

Camp Dresser \& McKee [CDM], 2003, Suffolk County groundwater model, final report: CDM-Smith, Woodbury, N.Y.

Cape Cod Commission, 2013, Regional wastewater management plan: Cape Cod Commission web page, accessed April 10, 2017, at http://www.capecodcommission.org/ index.php?id $=332 \&$ maincatid $=76$.

Center for Environmental Research and Coastal Oceans Monitoring [CERCOM], 2017, Protecting the community you live in: Molloy College web page, accessed January 5, 2017, at https://www.molloy.edu/academics/ undergraduate-programs/biology/cercom.

Chesapeake Bay Program, 2012, BMP—The framework elements: Chesapeake Bay Program web page, accessed April 10, 2017, at http://www.chesapeakebay.net/about/ programs/bmp/framework_elements.

Connecticut Fund for the Environment, 2016, Water quality monitoring: Connecticut Fund for the Environment web page, accessed April 10, 2017, at http://www.ctenvironment.org/water-quality. 
Corsi, S.R., Borchardt, M.A., Carvin, R.B., Burch, T.R., Spencer, S.K., Lutz, M.A., McDermott, C.M., Busse, K.M., Kleinheinz, G.T., Feng, Xiaoping, and Zhu, Jun, 2016, Human and bovine viruses and bacteria at three Great Lakes beaches-Environmental variable associations and health risk: Environmental Science \& Technology, v. 50, no. 2, p. 987-995. [Also available at https://doi.org/10.1021/ acs.est.5b04372.]

Deegan, L.A., Bowen, J.L., Drake, Deanne, Fleeger, J.W., Freidrichs, C.T., Galvan, K.A., Hobbie, J.E., Hopkinson, Charles, Johnson, D.S., Johnson, J.M., LeMay, L.E., and Miller, Erin, 2007, Susceptibility of salt marshes to nutrient enrichment and predator removal: Ecological Applications, v. 17 , no. 5, p. 42-63, accessed January 31, 2017, at http://www.jstor.org/stable/pdf/40061816.pdf. [Also available at https://doi.org/10.1890/06-0452.1.]

Doherty, A.C., and Brownawell, B.J., 2013, Quaternary ammonium compounds as sewage-source specific tracers of processes affecting the distribution of contaminants and sediments in Hempstead Bay, a Long Island coastal lagoon: Stony Brook University, School of Marine and Atmospheric Sciences, 6 p., accessed January 31, 2017, at http://www.geo.sunysb.edu/lig/Conferences/abstracts12/ Abstracts/Doherty.pdf.

EcoCheck, 2011, Sampling and data analysis protocols for Mid-Atlantic tidal tributary indicators: Mid-Atlantic Tributary Assessment Coalition, 52 p., accessed August 14, 2017, at http://ian.umces.edu/pdfs/ian_report_313.pdf.

EcoLogic LLC, 2000, Coordinated Water Resources Monitoring Strategy for the South Shore Estuary Reserve: South Shore Estuary Reserve Technical Report Series, 115 p.

Federal Emergency Management Agency [FEMA], [n.d.], FEMA flood map service center-Welcome: Federal Emergency Management Agency web page, accessed April 10, 2017, at https://msc.fema.gov/portal.

Federal Emergency Management Agency [FEMA], 2015, State mitigation plan review guide: Federal Emergency Management Agency FP 302-094-2, 51 p., accessed December 12, 2016, at https://www.fema.gov/medialibrary-data/1425915308555-aba3a873bc5f1140f7320d1ebebd18c6/State_Mitigation_Plan_Review_Guide_2015.pdf.

Fischer, J.M., Phillips, P.J., Reilly, T.J., Focazio, M.J., Loftin, K.A., Benzel, W.M., Jones, D.K., Smalling, K.L., Fisher, S.C., Fisher, I.J., Iwanowicz, L.R., Romanok, K.M., Jenkins, D.E, Bowers, Luke, Boehlke, Adam, Foreman, W.T., Deetz, A.C., Carper, L.G., Imbrigiotta, T.E., and Birdwell, J.E., 2015, Estuarine bed-sediment-quality data collected in New Jersey and New York after Hurricane Sandy, 2013: U.S. Geological Survey Data Series 905, 42 p. plus CD-ROM, accessed January 31, 2017, at http://dx.doi.org/10.3133/ds905.
Flagg, C.N., 2013, The impact on Great South Bay of the breach at Old Inlet, January 14, 2013: Stony Brook University, School of Marine and Atmospheric Sciences, 8 p., accessed January 31, 2017, at http://po.msrc.sunysb.edu/ GSB/Inlet_Report_2.pdf.

Flagg, C.N., Wilson, R.E., Hinrichs, Claudia, and Wilson, Tom, 2016, The Great South Bay project: Stony Brook University web page, accessed November 9, 2016, at http://po.msrc.sunysb.edu/GSB/.

Francy, D.S., Brady, A.M.G., Carvin, R.B., Corsi, S.R., Fuller, L.M., Harrison, J.H., Hayhurst, B.A., Lant, Jeremiah, Nevers, M.B., Terrio, P.J., and Zimmerman, T.M., 2013, Developing and implementing predictive models for estimating recreational water quality at Great Lakes beaches: U.S. Geological Survey Scientific Investigations Report 20135166, 68 p., accessed January 31, 2017, at http://dx.doi.org/10.3133/sir20135166.

Friends of the Bay, 2006, Friends of the Bay water quality monitoring program (WQMP)—Baywatch: Oyster Bay, N.Y., Friends of the Bay Quality Assurance Project Plan [variously paged], accessed December 22, 2016, at http://friendsofthebay.org/research-monitoring/ quality-assurance-project-plan-qapp/.

Fuss \& O'Neill, Inc., 2007, Friends of the Bay stream and outfall monitoring program: West Springfield, Mass., Fuss \& O'Neill [variously paged], accessed October 26, 2016, at http://friendsofthebay.org/research-monitoring/ quality-assurance-project-plan-qapp/.

Gobler, C.J., Berry, D.L., Anderson, O.R., Burson, Amanda, Florian, Kock, Rodgers, B.S., Moore, L.K., Goleski, J.A., Bassem, Allam, and Bowser, Paul, 2008, Characterization, dynamics, and ecological impacts of harmful Cochlodinium polykrikoides blooms on eastern long Island, NY, USA: Harmful Algae, v. 7, no. 3, p. 293-307, accessed October 2, 2017, at http://www.sciencedirect.com/science/article/pii/ S1568988307001850. [Also available at https://doi.org/10.1016/j.hal.2007.12.006.]

Gobler, C.J., Burson, Amanda, Koch, Florian, Tang, Yingzhong, and Mulholland, M.R., 2012, The role of nitrogenous nutrients in the occurrence of harmful algal blooms caused by Cochlodinium polykrikoides in New York estuaries (USA): Harmful Algae, v. 17, p. 64-74, accessed January 31, 2017, at http://www.sciencedirect.com/science/ article/pii/S1568988312000583. [Also available at https://doi.org/10.1016/j.hal.2012.03.001.]

Governor's Office of Storm Recovery [GOSR], [n.d.], About: Governor's Office of Storm Recovery web page, accessed April 10, 2017, at https://stormrecovery.ny.gov/about. 
Governor's Office of Storm Recovery [GOSR], 2014, Governor Cuomo announces action to strengthen coastal resiliency against future storms of Long Island: Governor's Office of Storm Recovery web page, accessed April 10, 2017, at http://www.governor.ny.gov/news/governorcuomo-announces-actions-strengthen-coastal-resiliencyagainst-future-storms-long.

Governor's Office of Storm Recovery [GOSR], 2017, Programs - Long Island: Governor's Office of Storm Recovery web page, accessed April 10, 2017, at https://stormrecovery.ny.gov/community-regions/ long-island.

Great Lakes Coastal Resilience, 2013, Great Lakes Coastal Resilience planning guide: Great Lakes Coastal Resilience case studies web page, accessed April 10, 2017, at http:/greatlakesresilience.org/case-studies.

Great Lakes Restoration Initiative, [2016], Great Lakes Restoration Initiative- Home: Great Lakes Restoration Initiative web page, accessed June 20, 2016, at https://www.glri.us/ index.html.

Griffin, D.W., Stokes, Rodger, Rose, J.B., and Paul, J.H., III, 2000, Bacterial indicator occurrence and the use of an F+ specific RNA coliphage assay to identify fecal sources in Homosassa Springs, Florida: Microbial Ecology, v. 39, no. 1, p. 56-64. [Also available at https://doi.org/10.1007/ s002489900193.]

Hattenrath-Lehmann, T.K., Marcoval, M.A., Mittlesdorf, Heidi, Goleski, J.A., Wang, Zhihong, Haynes, Bennie, Morton, S.L., and Gobler, C.J., 2015, Nitrogenous nutrients promote the growth and toxicity of Dinophysis acuminata during estuarine bloom events: PLOS One, v. 10, no. 4, 22 p. [Also available at https://doi.org/10.1371/ journal.pone.0124148.]

Heisler, John, Glibert, P.M., Burkholder, J.M., Anderson, D.M., Cochlan, W.P., Dennison, W.C., Dortch, Q., Gobler, C.J., Heil, C.A., Humphries, E., Lewitus, A.J, Magnien, R.E., Marshall, H.G., Sellner, K.G., Stockwell, D.A., Stoecker, D.K., and Suddleson, M., 2008, Eutrophication and harmful algal blooms-A scientific consensus: U.S. Environmental Protection Agency Paper 169, accessed January 31, 2017, at http://digitalcommons.unl.edu/ usepapapers/169. [Also available at https://doi.org/10.1016/j.hal.2008.08.006.]

Hempstead Harbor Protection Committee, 2017, Hempstead Harbor.org: Hempstead Harbor Protection Committee web page: accessed May 5, 2016, at http://www.hempsteadharbor.org/.
Horton, R.D., Bader, D.A., Rosenzweig, Cynthia, DeGaetano, A.T., and Solecki, William, 2014, Climate change in New York State-Updating the 2011 ClimAID climate risk information supplement to NYSERDA Report 11-18 (responding to climate change in New York State): Albany, N.Y., New York State Energy Research and Development Authority (NYSERDA), 17 p., accessed April 10, 2017, at https://www.nyserda.ny.gov/-/ media/Files/Publications/Research/Environmental/ ClimAID/2014-ClimAid-Report.pdf.

Hydroqual, 2013, Water quality assessment of the impact of the Bay Park Sewage Treatment Plant in the days after Hurricane Sandy: Mahwah, N.J., Hydroqual, 149 p.

Kenward, Alyson, Yawitz, Daniel, and Raja, Urooj, 2013, Sewage overflows from Hurricane Sandy: Princeton, N.J., Climate Central, 37 p., accessed January 31, 2017, at www.climatecentral.org/pdfs/Sewage.pdf.

Kinney, E.L., and Valiela, Ivan, 2011, Nitrogen loading to Great South Bay - Land use, sources, retention, and transport from land to bay: Journal of Coastal Research, v. 27, no. 4, p. 672-686, accessed January 31,2017 , at https://www.researchgate.net/publication/261964090 Nitrogen_Loading_to_Great_South_Bay_Land_ Use_Sources_Retention_and_Transport_from_Land to_Bay. [Also available at https://doi.org/10.2112/ JCOASTRES-D-09-00098.1.]

Leuzzi, Linda, 2015, Research project attracts county wetlands benefits: The Long Island Advance, July 23, accessed April 10, 2017, at https://www.longislandadvance.net/2149/ Research-project-attracts-county-wetlands-benefits.

Lloyd, Stephen, 2014a, Nitrogen load modeling to forty-three subwatersheds of the Peconic Estuary: The Nature Conservancy, accessed August 14, 2017, at https://www.conservationgateway.org/ConservationByGeography/NorthAmerica/ UnitedStates/edc/Documents/Nitrogen\%20load\%20 modeling $\% 20$ to $\% 20$ the $\% 20$ Peconic $\% 20$ Estuary $\% 20-\% 20$ TNC\%20May\%202014.pdf.

Lloyd, Stephen, 2014b, Nitrogen loading sources-Oyster Bay and Huntington: The Nature Conservancy web page, accessed June 17, 2016, at https://www.nature.org/ ourinitiatives/regions/northamerica/unitedstates/newyork/ lloyd-nitrogen-loading-sources-liu-presentation-oct-7. pdf?redirect $=$ https-301.

Lyerly, C.M., Hernández Cordero, A.L., Foreman, K.L., Phillips, S.W., and Dennison, W.C., eds., 2014, New insightsScience-based evidence of water quality improvements, challenges, and opportunities in the Chesapeake: College Park, Md., University of Maryland Center for Environmental Science, $52 \mathrm{p}$. 
Manson, Steven, Schroeder, Jonathan, Van Riper, David, and Ruggles, Steven, 2017, IPUMS National Historical Geographic Information System — version 12.0 [database]: University of Minnesota, Minneapolis, accessed October 19, 2017, at http://doi.org/10.18128/D050.V12.0.

Misut, P.E., 2011, Simulation of groundwater flow in a volatile organic compound-contaminated area near Bethpage, Nassau County, New York-A discussion of modeling considerations: U.S. Geological Survey Open-File Report 2011-1128, 19 p. [Also available at http://pubs.usgs.gov/ of/2011/1128/].

Möller, Iris, Kudella, Matthias, Rupprecht, Franziska, Spencer, Tom, Paul, Maike, Wesenbeeck, B.K. van, Wolters, Guido, Jensen, Kai, Bouma, T.J., Miranda-Lange, Martin, and Schimmels, Stefan, 2014, Wave attenuation over coastal salt marshes under storm surge conditions: Nature Geosciences, v. 7, p. 727-731, accessed January 31, 2017, at http://www.nature.com/ngeo/journal/v7/n10/pdf/ ngeo2251.pdf. [Also available at https://doi.org/ doi:10.1038/ngeo2251.]

Monti, Jack, Jr., and Scorca, M.P., 2003, Trends in nitrogen concentration and nitrogen loads entering the South Shore Estuary Reserve from streams and ground-water discharge in Nassau and Suffolk Counties, Long Island, New York 1952-97: U.S. Geological Survey Water-Resources Investigations Report 02-4255, 36 p. [Also available at https://pubs.er.usgs.gov/publication/wri024255.]

National Oceanic and Atmospheric Administration [NOAA], 2012, Post Hurricane Sandy, NOAA aids hazardous spill cleanup in New Jersey and New York: National Oceanic and Atmospheric Administration Office of Response and Restoration web page, accessed June 12, 2016, at http://response.restoration.noaa.gov/about/media/post-hurricane-sandy-noaa-aids-hazardous-spill-cleanup-new-jerseyand-new-york.html.

National Oceanic and Atmospheric Administration [NOAA], 2014, Sea, lake, and overland surges from hurricanes (SLOSH): National Oceanic and Atmospheric Administration National Hurricane Center web page, accessed June 12, 2016, at http://www.nhc.noaa.gov/surge/slosh.php.

National Oceanic and Atmospheric Administration [NOAA], [2016], Mean sea level trend 8519483 Bergen Point, NY: National Oceanic and Atmospheric Administration mean sea level database, accessed June 17, 2017, at http://tidesandcurrents.noaa.gov/sltrends/ sltrends_station.shtml?stnid $=8519483$.

National Oceanic and Atmospheric Administration [NOAA], 2017b, National Data Buoy Center: National Oceanic and Atmospheric Administration Buoy database, accessed April 20, 2017, at http://www.ndbc.noaa.gov/.
National Oceanic and Atmospheric Administration [NOAA], 2017a, NOAA's national status and trends: National Oceanic and Atmospheric Administration database, accessed April 10, 2017, at https://products.coastalscience.noaa.gov/ collections/nsandt/default.aspx.

National Park Service [NPS], [n.d.], Integrated resource management applications portal: National Park Service web page, accessed July 14, 2016, at https://irma.nps.gov/Portal.

National Park Service [NPS], 2016, Park species lists: National Park Service Northeast Coastal and Barrier Network web page, accessed July 14, 2016, at http://science.nature.nps.gov/im/units/ncbn/species.cfm.

National Park Service [NPS], 2017, Breaches: National Park Service Fire Island web page, accessed April 10, 2017, at https://www.nps.gov/fiis/learn/nature/breaches.htm.

News12, 2016, The Long Island water quality index: News 12 data, August 31, 2016, accessed July 14, 2016, at http://data.news12.com/long-island/data/water/quality/.

New York State Department of Environmental Conservation [NYSDEC], [n.d.]a, Harmful algal blooms and marine biotoxins: New York State Department of Environmental Conservation web page, accessed January 19, 2018, at http://www.dec.ny.gov/outdoor/64824.html.

New York State Department of Environmental Conservation [NYSDEC], [n.d]b, Nassau and Suffolk Counties trends in wetland loss: New York State Department of Environmental Conservation web page, accessed April 10, 2017, at http://www.dec.ny.gov/lands/31989.html.

New York State Department of Environmental Conservation [NYSDEC], [n.d.]c, Rotating Integrated Basin Studies (RIBS): New York State Department of Environmental Conservation web page, accessed November 20, 2016, at http://www.dec.ny.gov/chemical/30951.html.

New York State Department of Environmental Conservation [NYSDEC], [n.d.]d, Strategy for addressing loss of intertidal marsh in the marine district: New York State Department of Environmental Conservation web page, accessed March 1, 2016, at http://www.dec.ny.gov/lands/31879.html.

New York State Department of Environmental Conservation [NYSDEC], 2004, South Shore tidal wetlands bird conservation area: New York State Department of Environmental Conservation web page, accessed January 19, 2018, at http://www.dec.ny.gov/animals/27026.html.

New York State Department of Environmental Conservation [NYSDEC], 2008, Response to comments on the draft MS4 permit, April 2008, appendix D of Stormwater assessment and design modeling tools for implementation of stormwater management plans: Albany, N.Y., New York State Department of Environmental Conservation, 32 p. 
New York State Department of Environmental Conservation [NYSDEC], [2012], Long Island MS4 phase II planning program: New York State Department of Environmental Conservation web page, accessed December 3, 2015, at http://www.dec.ny.gov/lands/71195.html.

New York State Department of Environmental Conservation [NYSDEC], [2014]a, Community Risk and Resiliency Act (CRRA) provisions - CRRA summary: New York State Department of Environmental Conservation, accessed April 10, 2017, at http://www.dec.ny.gov/ energy/104113.html.

New York State Department of Environmental Conservation [NYSDEC], 2014b, Nitrogen pollution and adverse impacts on resilient tidal marshlands: New York State Department of Environmental Conservation Technical Briefing Summary, 8 p., accessed January 31, 2017, at http://www.dec.ny.gov/ docs/water_pdf/impairmarshland.pdf.

New York State Department of Environmental Conservation [NYSDEC], [2014]c, Sea level rise-What is expected for New York: New York State Department of Environmental Conservation web page, accessed June 4, 2016, at http://www.dec.ny.gov/energy/45202.html.

New York State Department of Environmental Conservation [NYSDEC], 2014d, 2014 Section 303(d) List of impaired waters requiring a TMDL/other strategy: New York State Department of Environmental Conservation Final 2014 Section 303(d) List, 45 p., accessed April 10, 2017, at https://www.epa.gov/sites/production/files/2015-10/ documents/ny_303dlist_final_2014_2014-11-3.pdf.

New York State Department of Environmental Conservation [NYSDEC], 2015, New York State Stormwater Management Design Manual: New York State Department of Environmental Conservation web page, 578 p., accessed October 10, 2017, at http://www.dec.ny.gov/ chemical/29072.html.

New York State Department of Environmental Conservation [NYSDEC], [2016]a, Biomonitoring: New York Department of Environmental Conservation web page, accessed April 10, 2017, at http://www.dec.ny.gov/chemical/23847.html.

New York State Department of Environmental Conservation [NYSDEC], [2016]b, State pollutant discharge elimination system (SPDES) permit program-Article 17, title 8, Environmental Conservation law implementing regulations: New York Department of Environmental Conservation web page, accessed July 28, 2017, at http://www.dec.ny.gov/ permits/6054.html.

New York State Department of Environmental Conservation [NYSDEC], [2017], Long Island Nitrogen Action Plan (LINAP): New York State Department of Environmental Conservation web page, accessed March 2017 at http://www.dec.ny.gov/lands/103654.html.
New York State Department of State [NYSDOS], 2017, South Shore Estuary Reserve: New York Department of State Office of Planning, Development and Community Infrastructure web page, accessed July 28, 2017, at https://www.dos.ny.gov/opd/sser/.

New York State Department of State Division of Coastal Resources South Shore Estuary Reserve Council, 2008, Stormwater Infrastructure Mapping Inventory and Assessment C000266: Albany, N.Y., Browne Management Systems, Inc., 26 p., accessed March 2017 at https://www.dos.ny.gov/opd/sser/pdf/SW\%20Infa\%20 Mapping_Final_2-20-08.pdf.

New York State Energy Research and Development Authority, 2014, Climate change in New York State-Updating the 2011 ClimAID Climate Risk Information: Albany, N.Y., New York State Energy Research and Development Authority Final Report 14-26, 17 p., accessed July 14, 2016, at https://www.nyserda.ny.gov/About/Publications/Researchand-Development-Technical-Reports/EnvironmentalResearch-and-Development-Technical-Reports/Responseto-Climate-Change-in-New-York.

New York State Governor's Office, 2017, Governor Cuomo Announces \$10.4 Million Effort to Improve Long Island Water Quality, Restore Shellfish Populations and Bolster Resiliency of Coastal Communities: New York State Governor's Office web page, accessed October 31, 2017, at https://www.governor.ny.gov/news/governor-cuomoannounces-104-million-effort-improve-long-island-waterquality-restore-shellfish.

New York State Sea Level Rise Task Force, 2010, Report to the Legislature: New York State Department of Environmental Conservation Office of Long-Term Sustainability, 79 p., accessed January 31, 2017, at http://www.dec.ny.gov/ docs/administration_pdf/slrtffinalrep.pdf.

New York State Seagrass Task Force, 2009, Final report of the New York State seagrass taskforce-Recommendations to the New York State Governor and Legislature: Albany, N.Y., New York Seagrass Taskforce [variously paged], accessed January 31, 2017, at http://www.dec.ny.gov/lands/4932.html.

Operation Splash, 2016, Operation Splash-A non-profit, volunteer organization committed to improving the quality of life on Long Island's shores: Operation Splash website, accessed April 10, 2017, at http://www.operationsplash.net.

Paerl, H.W., 1997, Coastal eutrophication and harmful algal blooms-Importance of atmospheric deposition and groundwater as "new" nitrogen and other nutrient sources: Limnology and Oceanography, v. 42, no. 5, [part 2], p. 1154-1165. 
Pickerell, Christopher, and Schott, Stephen, 2014, Peconic Estuary program 2014 long-term eelgrass (Zostera marina) monitoring program: Yaphank, N.Y., Peconic Estuary Program Office [variously paged], accessed April 20, 2016, at http://www.peconicestuary.org/reports.php.

Puget Sound Partnership, 2012, The 2012/2013 action agenda for Puget Sound: Olympia, Wash., Puget Sound Partnership, 481 p., accessed January 31, 2017, at http://www.psp.wa.gov/downloads/AA2011/083012_final/ Action\%20Agenda\%20Book\%202_Aug\%2029\%202012. pdf.

Rosenzweig, Cynthia, Solecki, William, DeGaetano, Arthur, O'Grady, Megan, Hassol, Susan, and Grabhorn, Paul, eds., 2011, Responding to climate change in New York State-The ClimAID integrated assessment for effective climate change adaptation: Albany, N.Y., New York State Energy Research and Development Authority, Technical Report 11-18, accessed April 10, 2017, at https://www.nyserda.ny.gov.

Stark, Jeroen, Van Oyen, Tomas, Meire, Patrick, and Temmerman, Stign, 2015, Observations of tidal and storm surge attenuation in a large tidal marsh: Limnology and Oceanography, v. 60, no. 4, p. 1371-1381, accessed January 31,2017, at http://onlinelibrary.wiley.com/doi/10.1002/ lno.10104/full. [Also available at https://doi.org/10.1002/ lno.10104.]

Stinnette, Isabelle, 2014, Nitrogen loading to the South Shore, eastern bays, NY - Sources, impacts, and management options: Stony Brook, N.Y., State University of New York at Stony Brook, Master's thesis, 85 p., accessed January 19, 2018, at https://ir.stonybrook.edu/xmlui/ handle/11401/76021.

Suffolk County Government, 2014, Suffolk Legislature approves funds for Carmans River fish ladder: Suffolk County Government web page, accessed April 10, 2017, at http://www.suffolkcountyny.gov/Departments/CountyExecutive/tabid/101/ctl/details/itemid/1097/mid/876/suffolklegislature-approves-funds-for-carmans-river-fish-ladder. aspx.

Suffolk County Government, 2015, Wastewater management, section 8 of Comprehensive Water Resources Management Plan: New York, Suffolk County Government, 165 p.

Suffolk County Government, 2016, Harmful algal blooms: Suffolk County Government web page, accessed April 10, 2017, at http://www.suffolkcountyny.gov/Departments/HealthServices/EnvironmentalQuality/Ecology/ MarineWaterQualityMonitoring/HarmfulAlgalBlooms.aspx.
Swanson, R.L., Wilson, R.E., and Willig, K.N., 2013, A synthesis of loadings, monitoring information, and impairments in the western bays-A Report for Battelle Memorial Institute and the New York State Department of State: Stony Brook, N.Y., Stony Brook University School of Marine and Atmospheric Sciences, 35 p.

Tampa Bay Estuary Program, 2013, About the Tampa Bay Estuary Program: Tampa Bay Estuary Program web page, accessed February 3, 2017, at http://www.tbep.org/ about_the_tampa_bay_estuary_program.html.

Tampa Bay Estuary Program, 2017, Program accomplishments: Tampa Bay Estuary Program web page, accessed February 3, 2017, at http://www.tbep.org/about_the_tampa bay_estuary_program-program_accomplishments.html.

Tanacredi, J.T., 2015, Summer Water Quality Monitoring Program 2014 - Great South Bay, Long Island, New YorkFinal report-Great South Bay: West Sayville, N.Y., Center for Environmental Research and Coastal Oceans Monitoring, $19 \mathrm{p}$.

The Gobler Laboratory, [n.d.], Contact: Stony Brook University web page, accessed April 10, 2017, at http://you.stonybrook.edu/goblerlab/contact/.

The Nature Conservancy, 2012, Great South Bay ecosystembased management plan: Albany, N.Y., Prepared for the New York State Department of State by The Nature Conservancy Long Island Chapter, $70 \mathrm{p}$., accessed January 31,2017 , at https://www.dos.ny.gov/opd/sser/pdf/ GSB_EBM_Plan.pdf.

Town of Brookhaven, 2013, The Carmans River conservation and management plan: Brookhaven, N.Y., Town of Brookhaven, $413 \mathrm{p}$.

Town of Hempstead, 2017, Conservation \& Waterways: Town of Hempstead web page, accessed April 10, 2017, at https://toh.li/conservation-and-waterways.

University of Maryland Center for Environmental Science, [2015]a, How healthy is your Chesapeake Bay? - Chesapeake Bay report card: University of Maryland Center for Environmental Science web page, accessed February 3,2107 , at https://ecoreportcard.org/report-cards/ chesapeake-bay/.

University of Maryland Center for Environmental Science, [2015]b, How healthy is your Long Island Sound?-Long Island Sound report card: University of Maryland Center for Environmental Science web page, accessed February 3, 2017, at https://ecoreportcard.org/report-cards/ long-island-sound/. 
U.S. Access Board, 2000, Section 508 standards for electronic and information technology: U.S. Access Board web page, accessed July 2, 2016, at https://www.access-board.gov/ guidelines-and-standards/communications-and-it/about-thesection-508-standards/guide-to-the-section-508-standards.

U.S. Census Bureau, [2014], Census of population and housing: United States Census Bureau Publications web page, accessed April 10, 2017, at http://www.census.gov/prod/ www/decennial.html.

U.S. Environmental Protection Agency [EPA], 2002, Guidance for quality assurance project plans: U.S. Environmental Protection Agency EPA QA/G-5, [variously paged]. [Also available at https://www.epa.gov/quality/ guidance-quality-assurance-project-plans-epa-qag-5.]

U.S. Environmental Protection Agency [EPA], 2014, Project quality assurance and quality control, chap. 1 of EPA, The SW-846 compendium: U.S. Environmental Protection Agency SW-846, 24 p. [Also available at https://www.epa.gov/hw-sw846/sw-846-compendium.]

U.S. Environmental Protection Agency [EPA], 2015, Getting up to speed - Ground water contamination: U.S. Environmental Protection Agency web page, accessed December 14, 2017, at https://www.epa.gov/sites/production/ files/2015-08/documents/mgwc-gwc1.pdf.

U.S. Environmental Protection Agency [EPA], 2016, How EPA manages the quality of its environmental data: U.S. Environmental Protection Agency web page, accessed April 20, 2017, at https://www.epa.gov/quality.

U.S. Environmental Protection Agency [EPA], 2017a, Clean Water Act section 303(d) - Impaired waters and total maximum daily loads (TMDLs): U.S. Environmental Protection Agency web page, accessed April 10, 2017, at https://www.epa.gov/tmdl.

U.S. Environmental Protection Agency [EPA], 2017b, Exposure assessment models - Virtual Beach (VB): U.S. Environmental Protection Agency web page, accessed June 18, 2017, at https://www.epa.gov/exposure-assessment-models/ virtual-beach-vb.

U.S. Environmental Protection Agency [EPA], 2017c, Stormwater management and green infrastructure research: U.S. Environmental Protection Agency water research web page, accessed April 10, 2017, at https://www.epa.gov/waterresearch/stormwater-management-and-green-infrastructureresearch.

U.S. Geological Survey [USGS], [2011], Groundwater investigation on Long Island: U.S. Geological Survey Long Island web page, accessed April 10, 2017, at https://ny.water.usgs.gov/projects/SOTA/.
U.S. Geological Survey [USGS], 2014, Hurricane SandyScience to support coastal resilience: U.S. Geological Survey hurricanes web page, accessed June 3, 2016, at https://www2.usgs.gov/hurricane/sandy/.

U.S. Geological Survey [USGS], 2016a, Great Lakes beach health-Real-time assessments: U.S. Geological Survey web page, accessed April 10, 2017, at https://archive.usgs.gov/archive/sites/greatlakesbeaches. usgs.gov/themes/real-time_assessments.html.

U.S. Geological Survey [USGS], 2016b, Fire Island coastal change-Storm impact and recovery - Hurricane SandyWilderness breach: U.S. Geological Survey web page, accessed April 20, 2017, at https://coastal.er.usgs.gov/ fire-island/research/sandy/sandy-breach.html.

U.S. Geological Survey [USGS], 2016c, Long Island-Overview: U.S. Geological Survey web page, accessed November 17, 2017, at https://ny.water.usgs.gov/projects/SOTA/ index.html.

U.S. Geological Survey [USGS], 2017a, Estuarine processes, hazards and ecosystems-Model development: U.S. Geological Survey web page, accessed April 10, 2017, at https://woodshole.er.usgs.gov/project-pages/estuaries/ modeldevelopment.html.

U.S. Geological Survey [USGS], 2017b, myUSGS: U.S. Geological Survey web page, accessed April 10, 2017, at https://my.usgs.gov/resources/.

Vaudrey, J.M.P., and Gallagher, Kimberly, 2013, The general QAPP for Long Island Sound volunteer coastal monitoring (with adaptation form): Groton, Conn., University of Connecticut, Department of Marine Sciences, 74 p.

Wagner, Melissa, Chhetri, Netra, and Sturm, Melanie, 2014, Adaptive capacity in light of Hurricane Sandy - the need for policy engagement: Applied Geography, v. 50, p. 15-23, accessed January 31,2017 , at https://doi.org/10.1016/j.apgeog.2014.01.009.

Wilde, F.D., ed., 2006, Collection of water samples (ver. 2.0): U.S. Geological Survey Techniques of WaterResources Investigations, book 9, chap. A4, [variously paged], accessed July 2, 2016, at https://pubs.er.usgs.gov/ publication/twri09A4.

Williams, Michael, Longstaff, Ben, Buchanan, Claire, Llansó, Roberto, and Dennison, William, 2009, Development and evaluation of a spatially-explicit index of Chesapeake Bay health: Marine Pollution Bulletin, v. 59, no. 1-3, p. 14-25.

Wippich, Carol, 2012, Preserving science for the ages-USGS data rescue: U.S. Geological Survey Fact Sheet 2012-3078, 4 p. [Also available at https://pubs.er.usgs.gov/publication/ fs20123078.] 
Wise, William, 2017, Suffolk County Harmful Algae Bloom Action Plan: New York Sea Grant and Suffolk County Government, 74 p., accessed October 31, 2017, at http://reclaimourwater.info/Portals/60/docs/

HABActionPlan.pdf.

Woods Hole Group, 2010, Long Island Sound regional dredged material management plan-Phase 2 literature review update: East Falmouth, Mass., Woods Hole Group, Inc. [variously paged]. 



\section{Tables 4A-B}

Table 4. List of water-quality and ecological monitoring programs ongoing or completed since 2000 in the South Shore Estuary Reserve, New York, with information on $A$, objectives and constituents and $B$, quality assurance and quality control, timeframes, and URLs. 


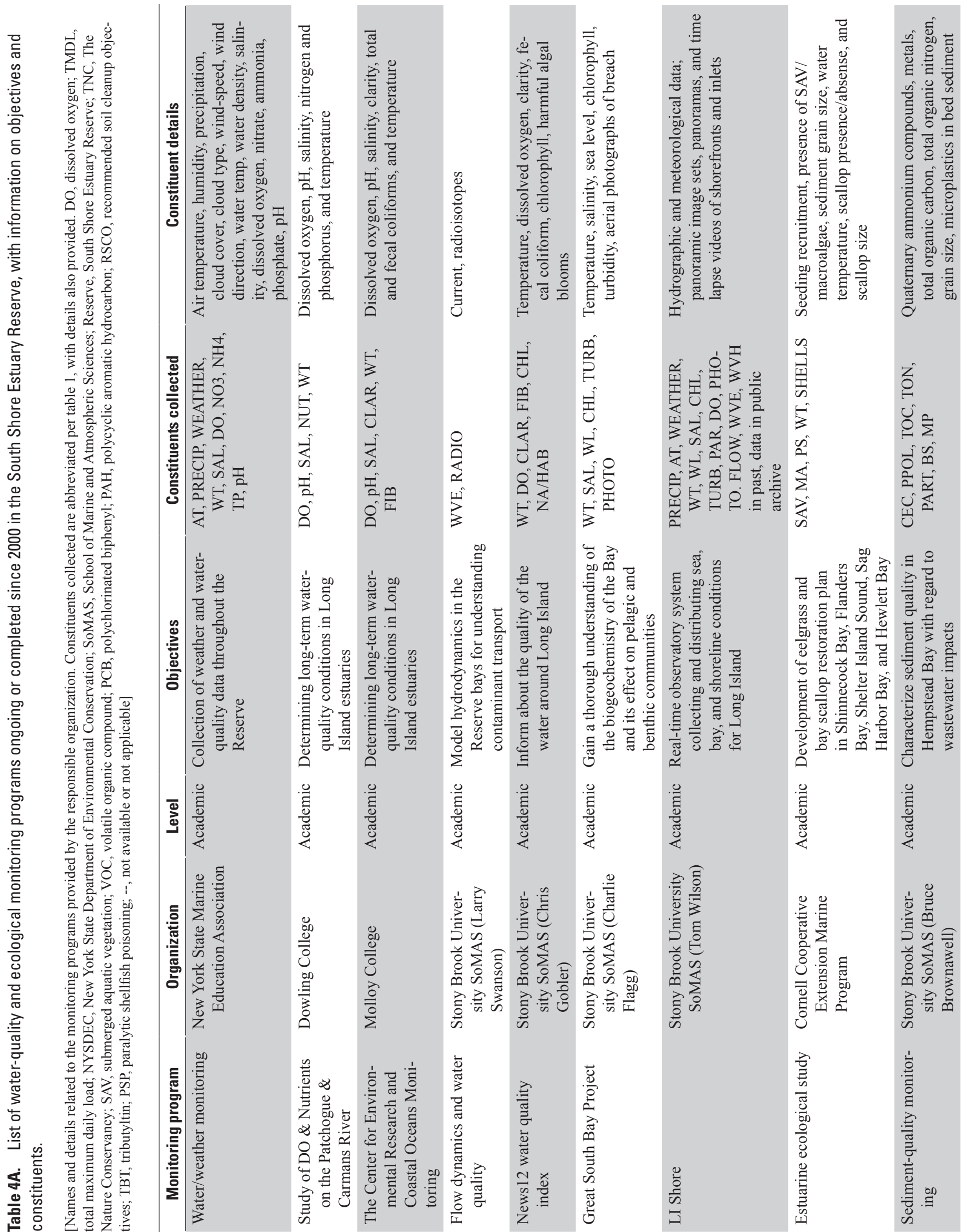


Table 4

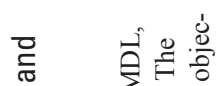

@ 氙苛

음

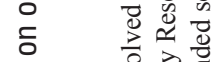

흔 员总

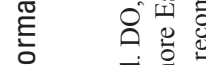

.

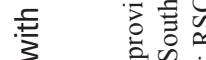

D $\quad$ के

$\stackrel{2}{8} \quad \frac{\pi}{8}$

壱

凹

के

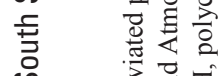

क

당

$5 \quad$ 敋

옹 च

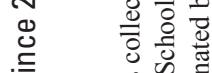

क

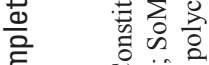

ह

के

을

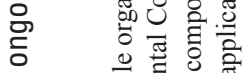

के क्षे

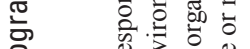

은

달

高 莺

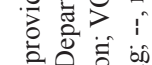

要

응 $\quad 50$

o of

흥

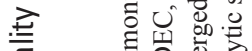

을

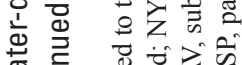

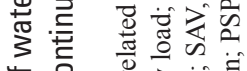

论

西然

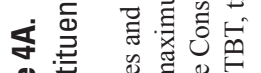

o

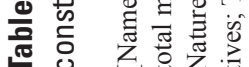
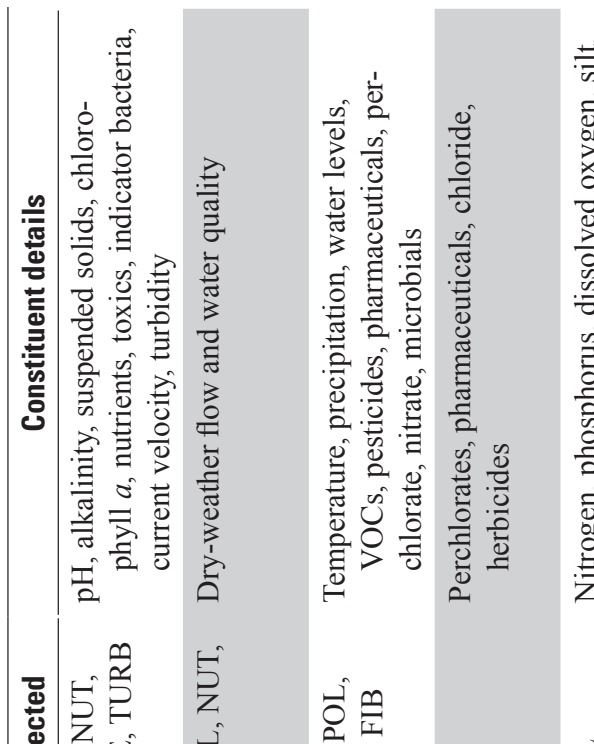

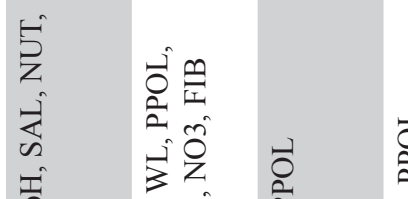

跣

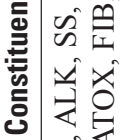

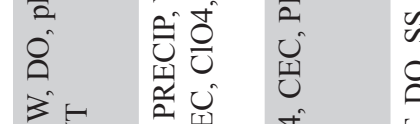

त्र

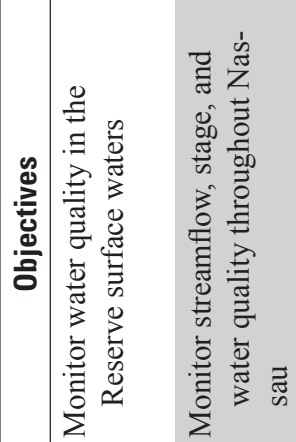

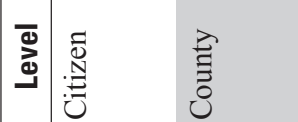

言

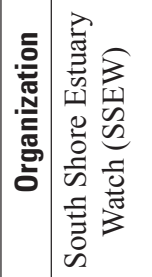

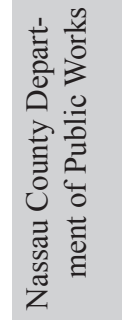

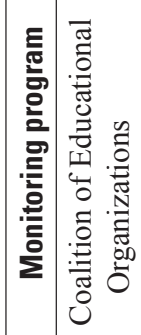

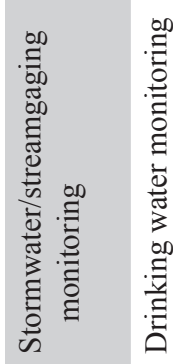

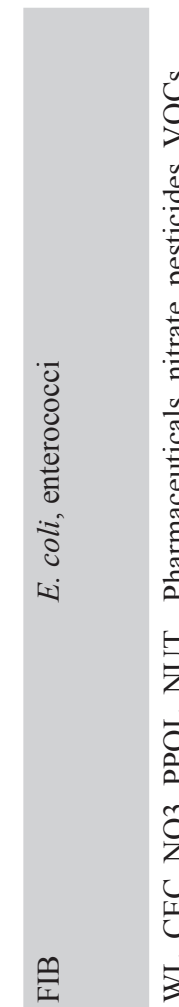

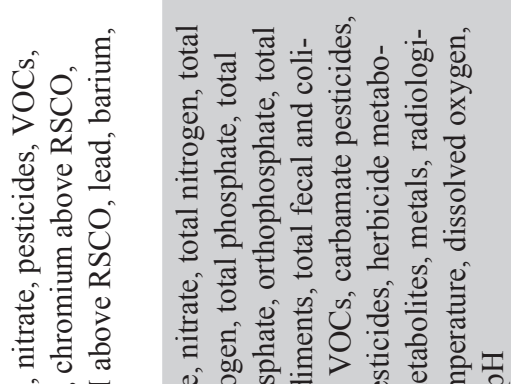

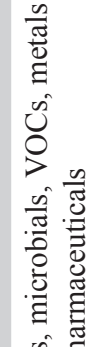

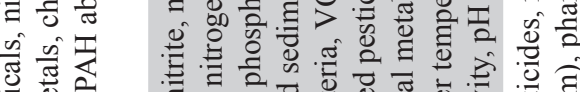

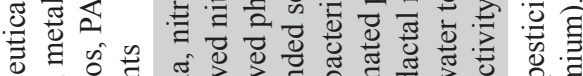

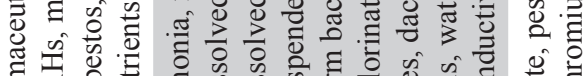

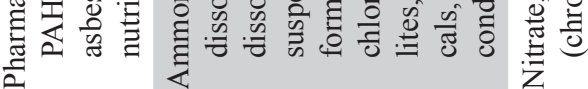

艺

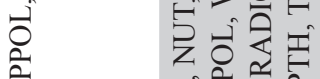

ô

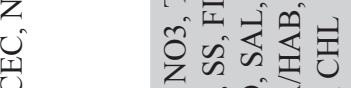

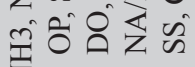

Z

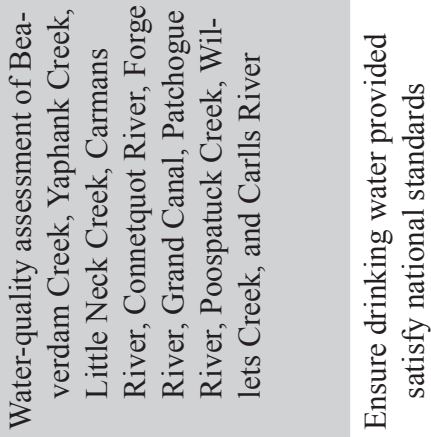

产

言

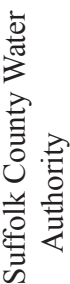

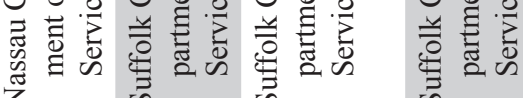

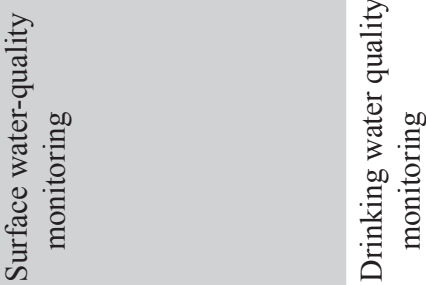




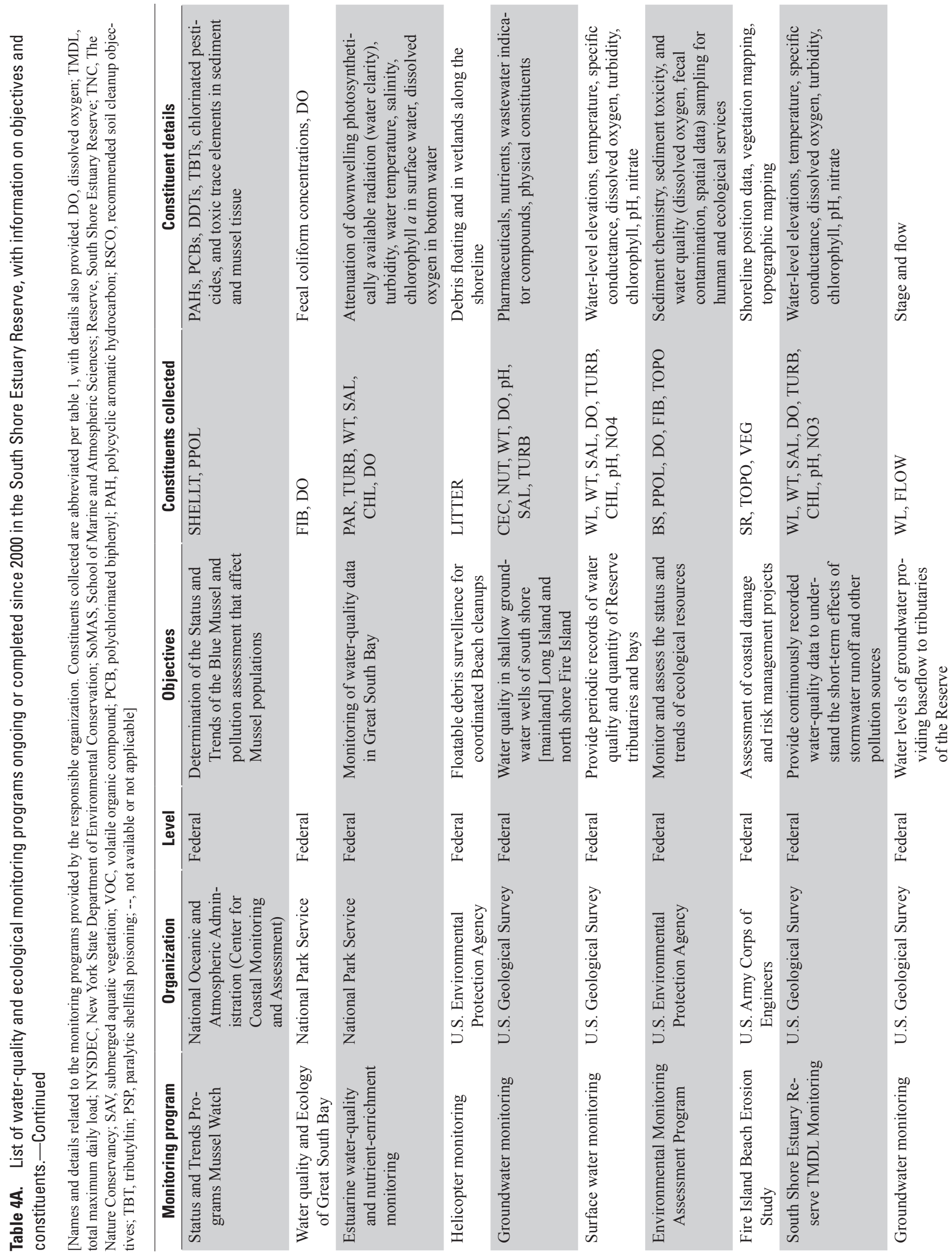


Table 4

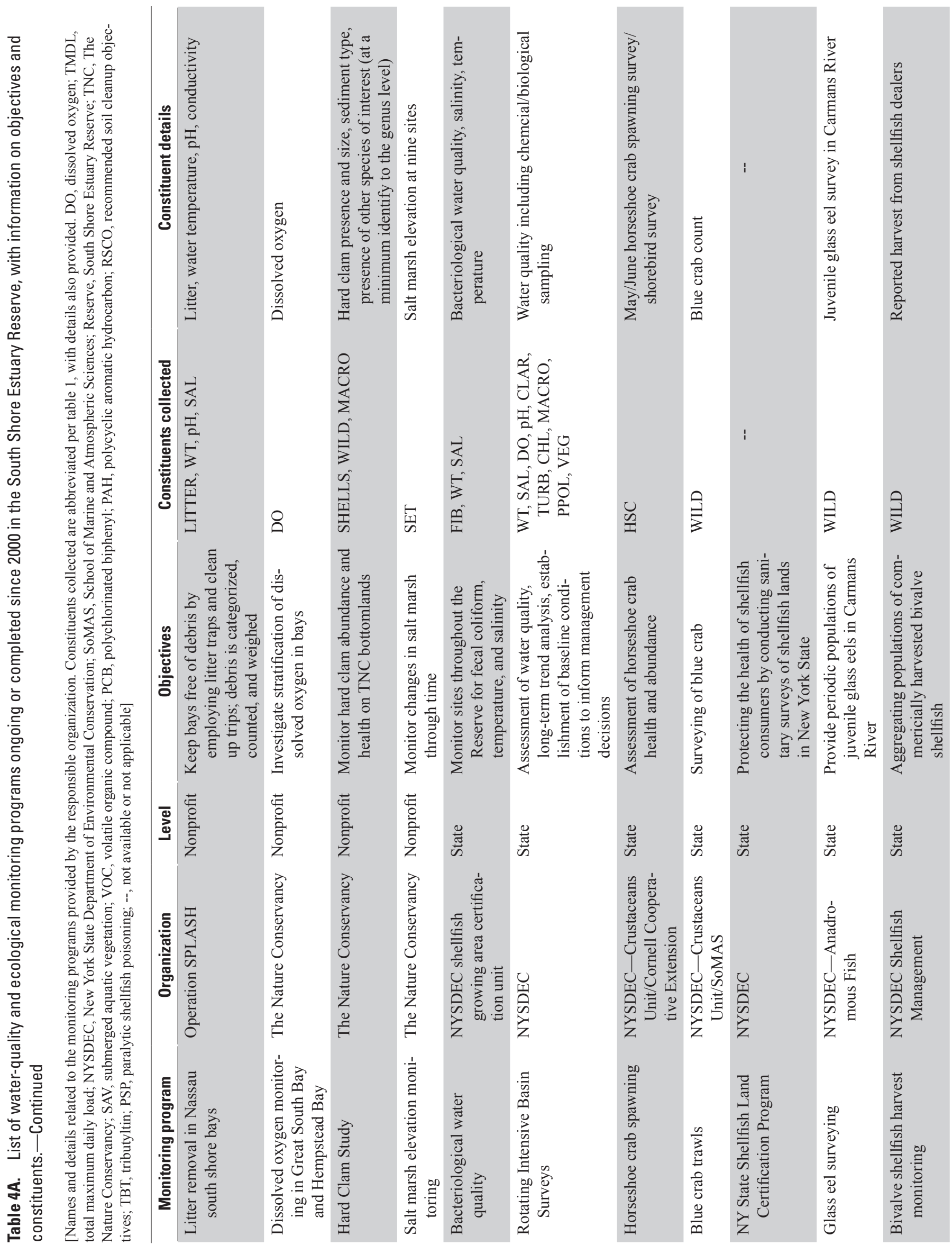




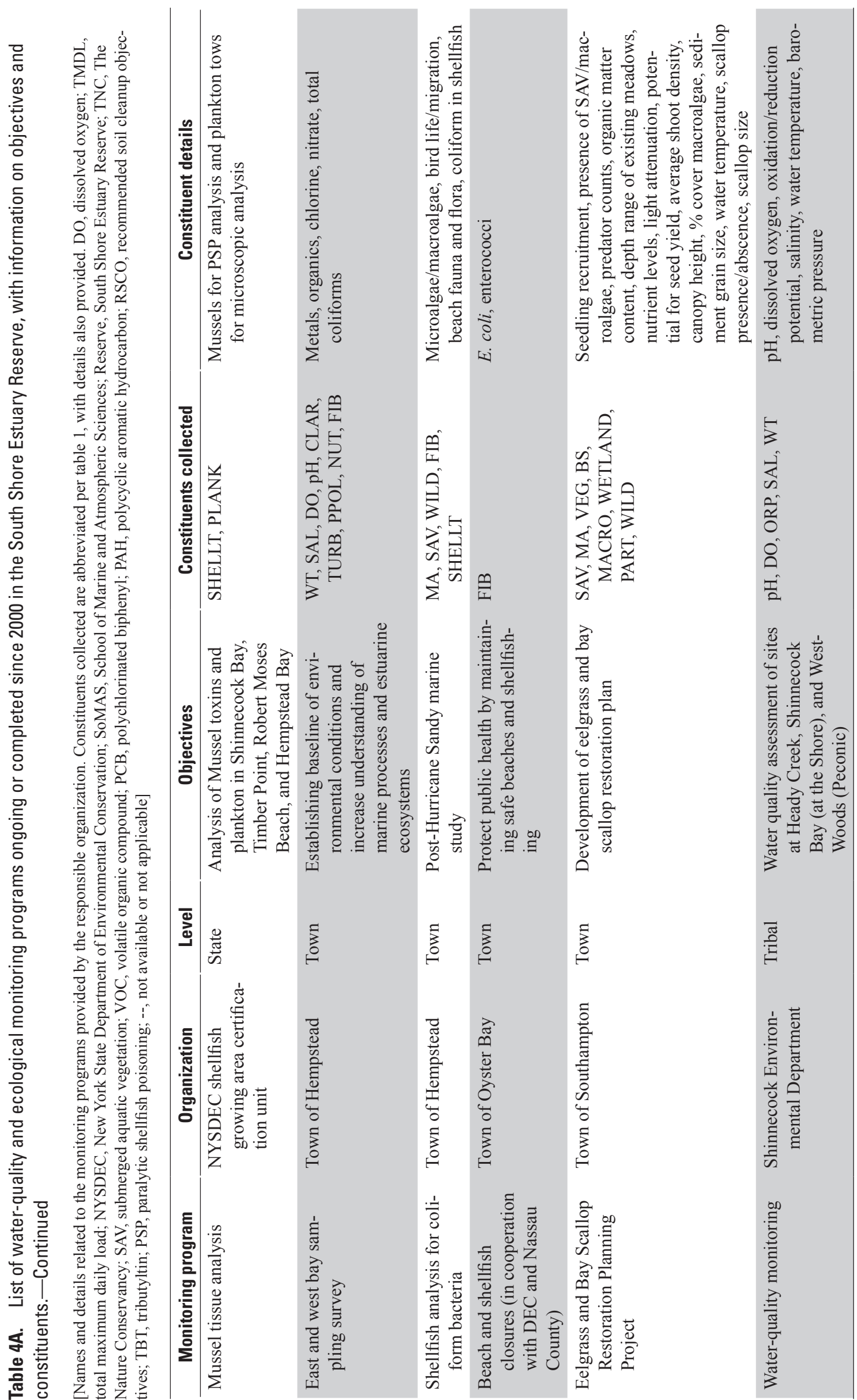




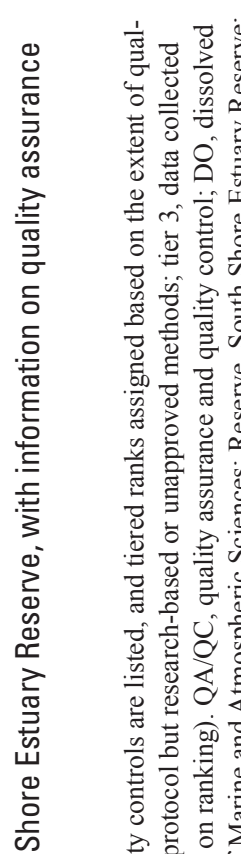

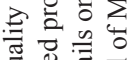

항

产 究

है

巻

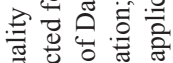

일

尊

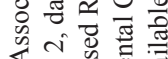

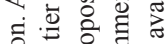

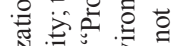

을 실

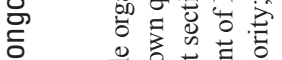

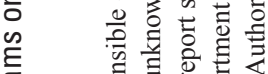

흉 क्षे

는

다유

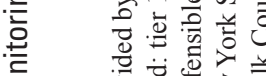

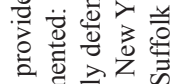

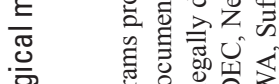

응 白

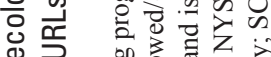

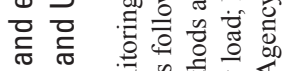

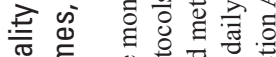

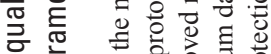

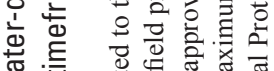

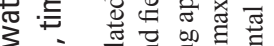

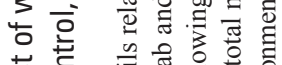

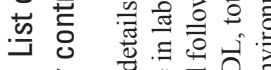

๓

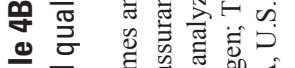

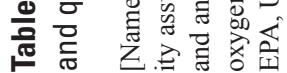

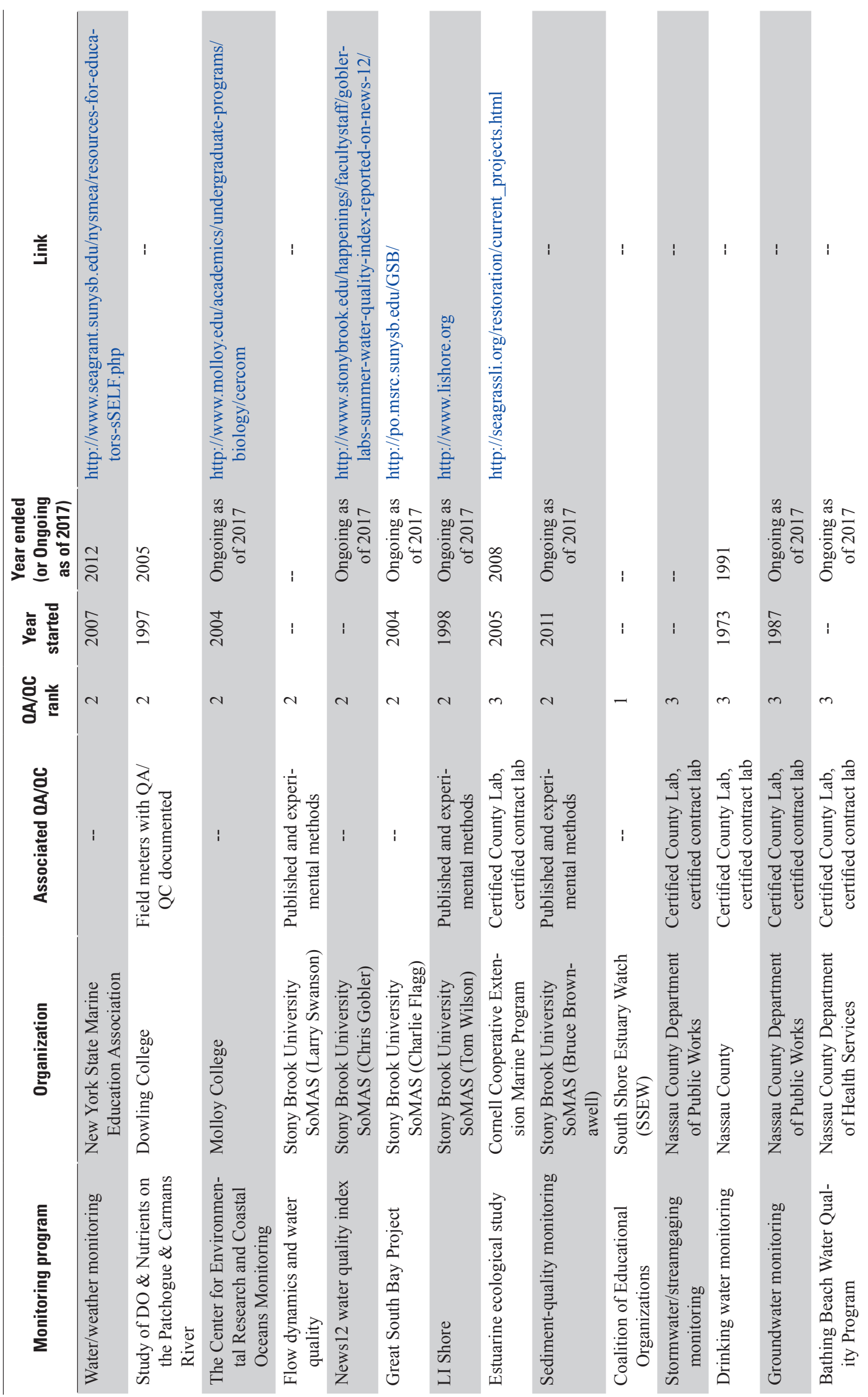




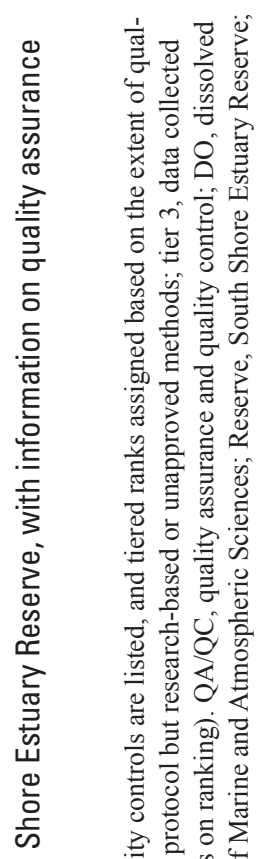

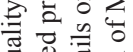

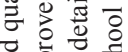

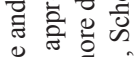

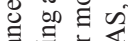

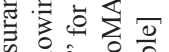

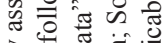

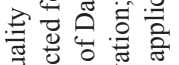

흥 엥ㅎㅇ

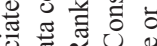

话

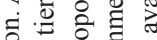

त्च

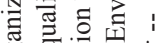

है डु

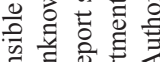

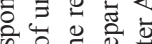

रे० ङ एँ जै

要 㐘

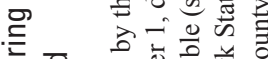

흥워

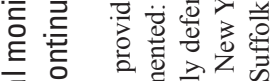

ত্

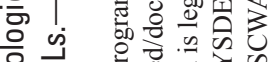

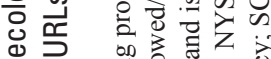

든

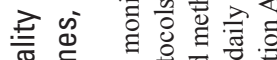

元

㐫离

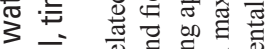

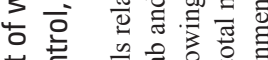

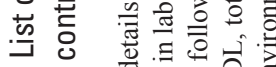

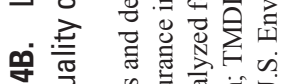

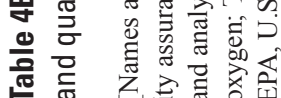

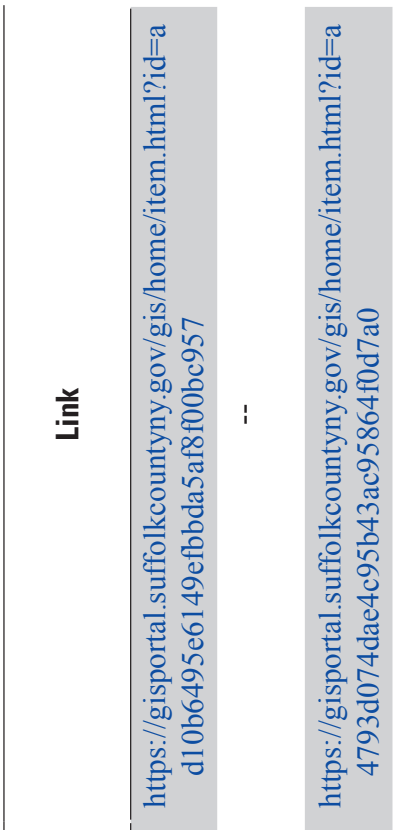

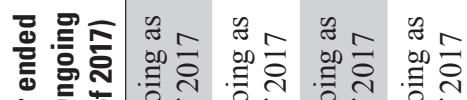

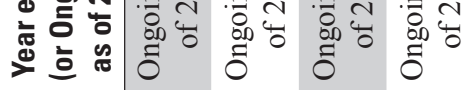

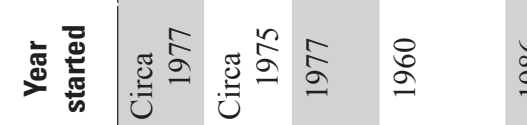

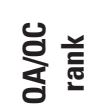

这

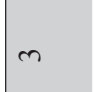

ப̊.

(n)

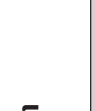

흘

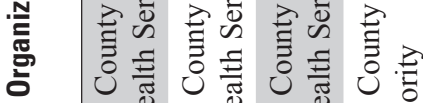

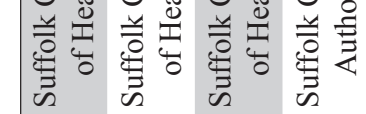
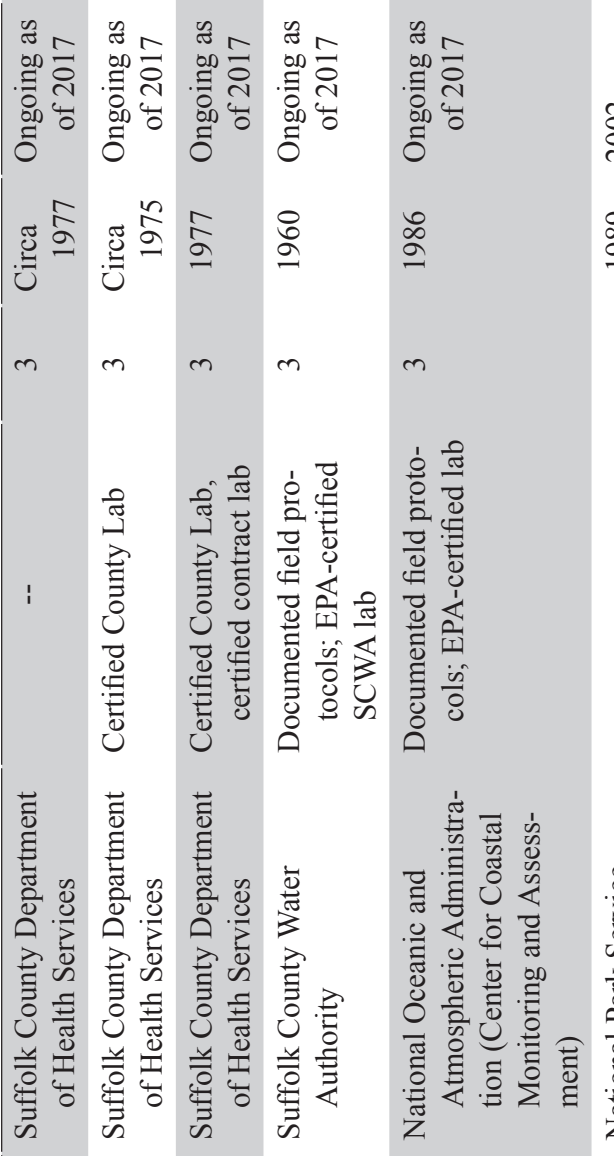

क.

章

产

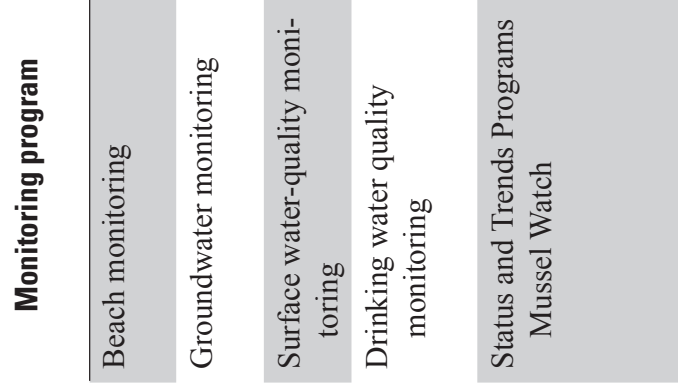

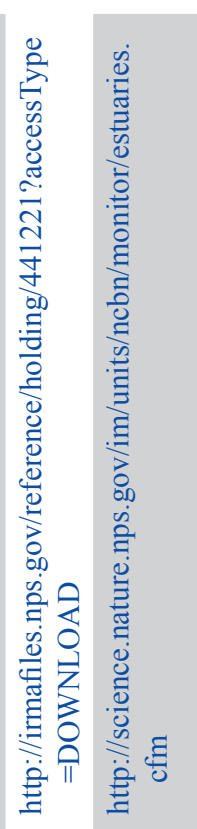
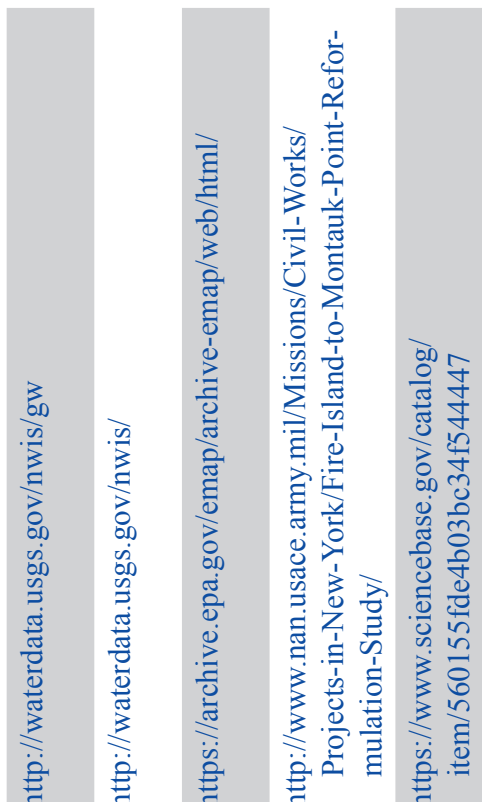

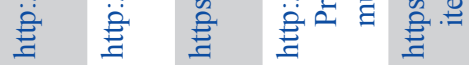
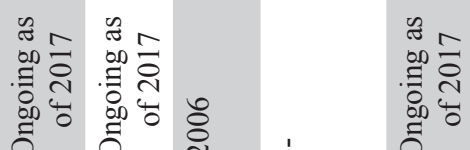

กิ

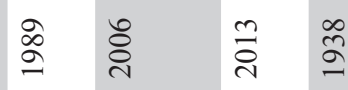

ஓ

ปั
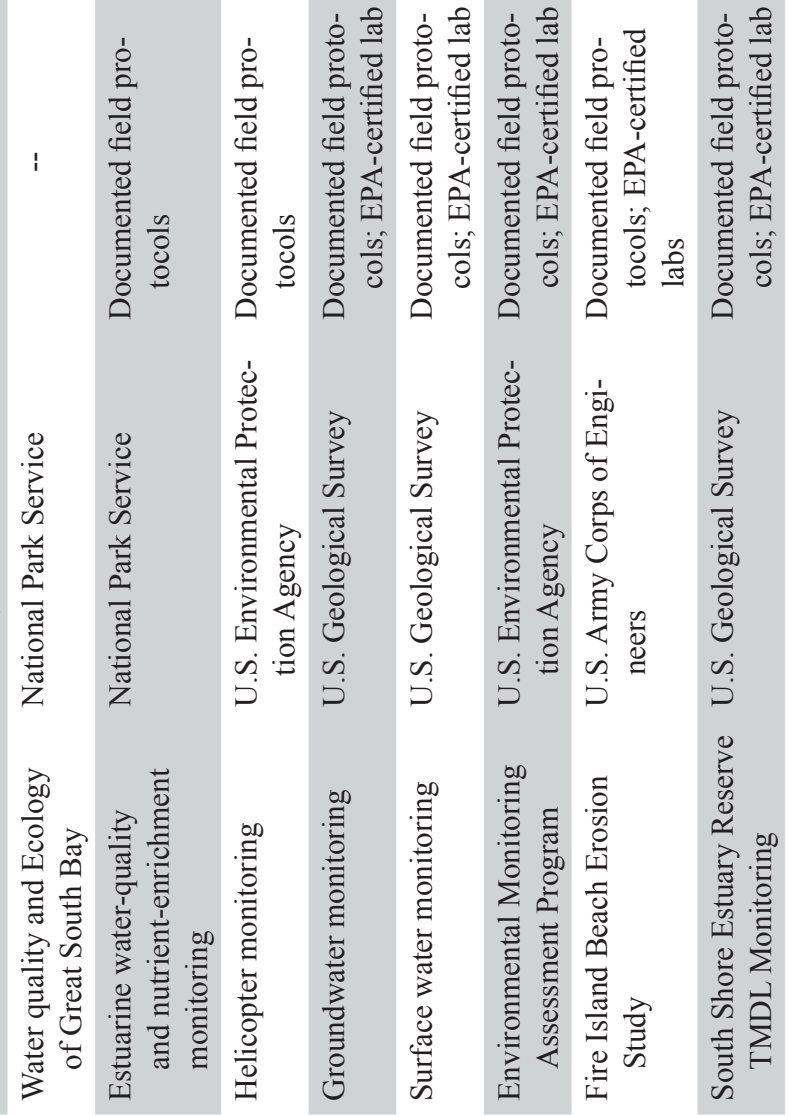
Table 4

67

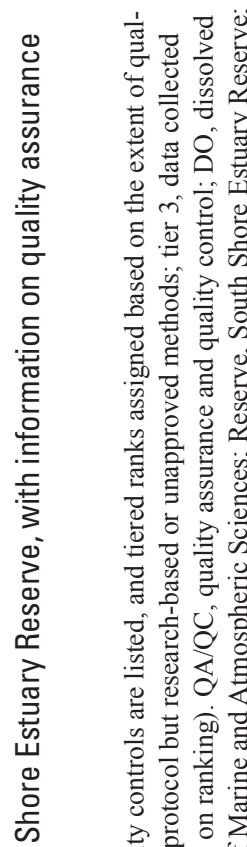
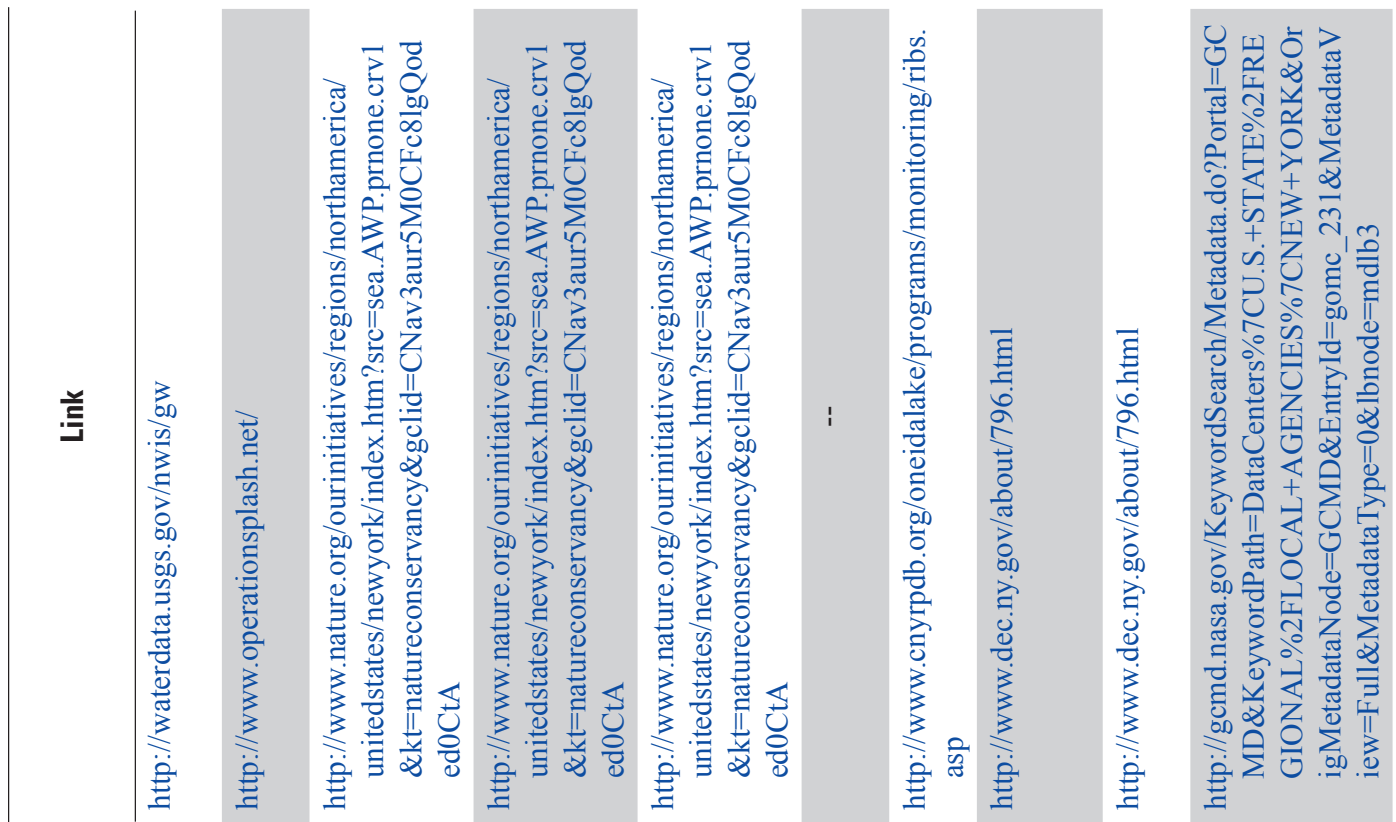

至

ॠ

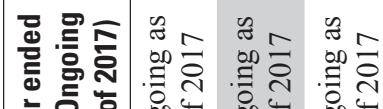

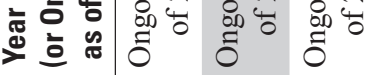
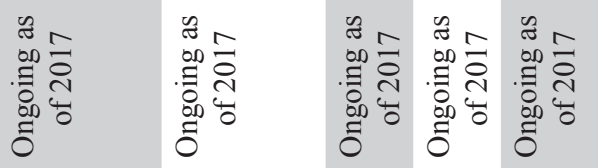

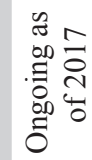

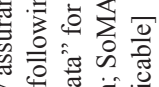

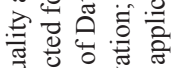

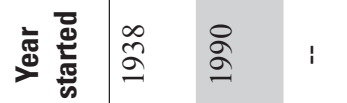

\&े

$\overline{\check{c}}$

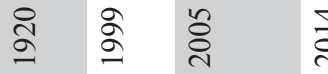

응

过尊 n $-n$

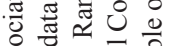

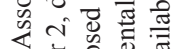

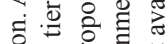

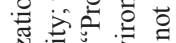

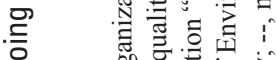

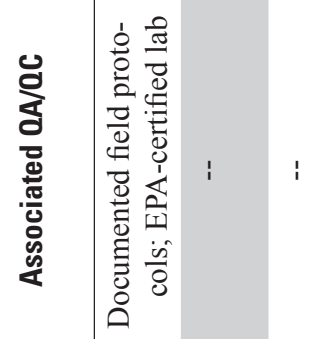

可 응

क्षे

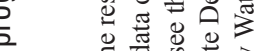

강

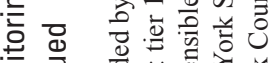

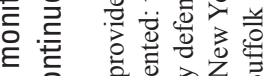

ত্

क

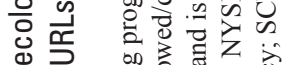

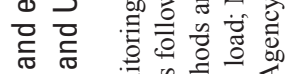

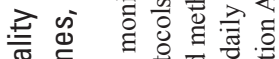

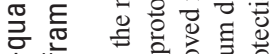

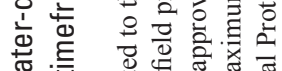

然

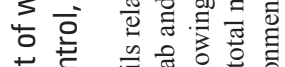

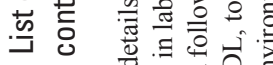

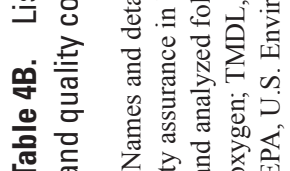

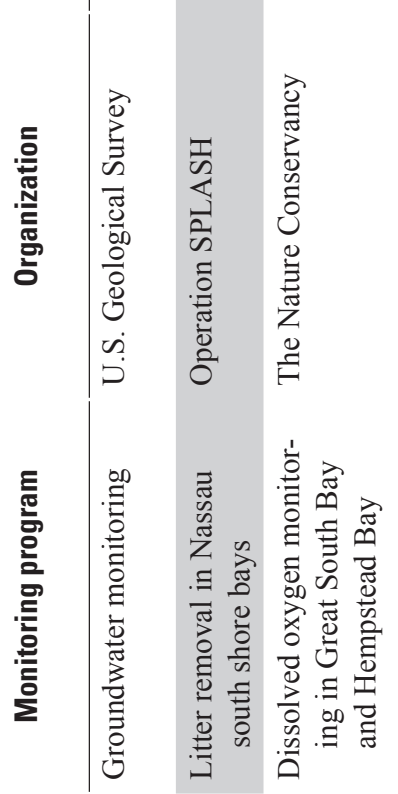

Oे

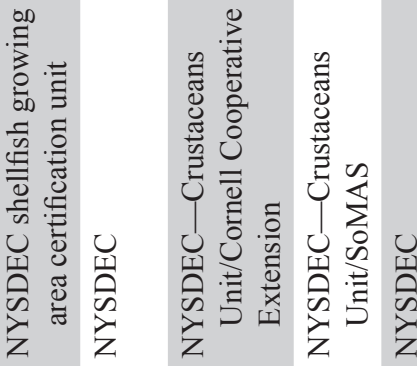




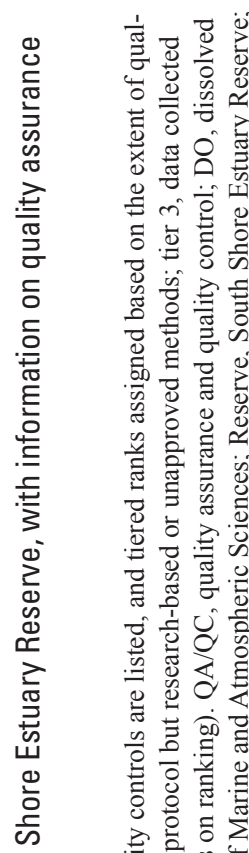

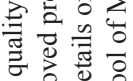

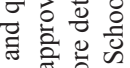

:

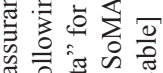

ส

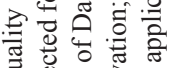

항 b

욤

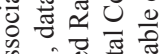

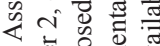

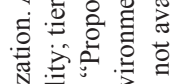

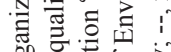

के ट्रे

웜

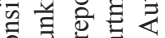

뉴ㅇㅝㅠ

䒕 0 0
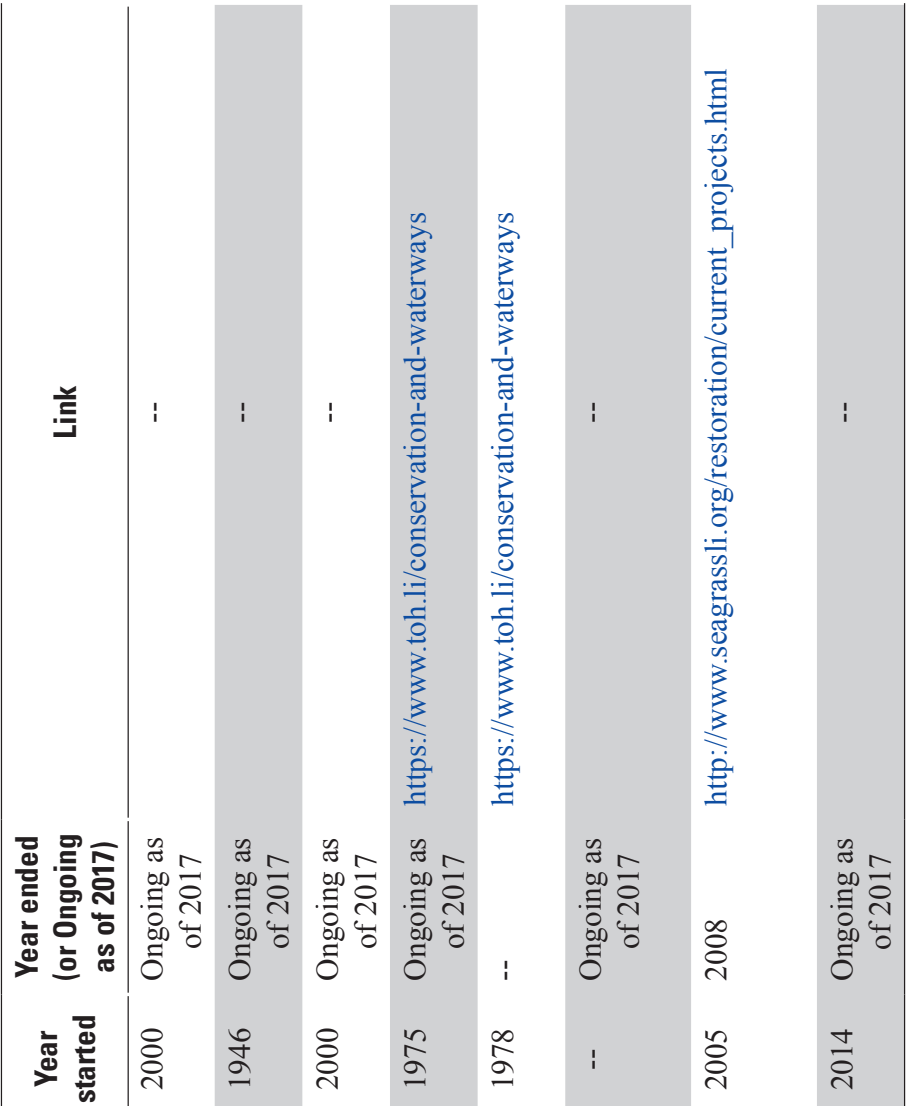

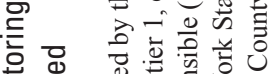

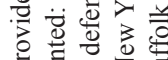

咅艺壳

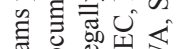

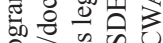

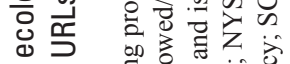

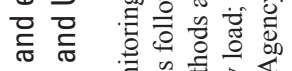

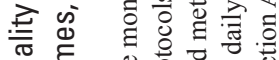

宁 盯

㐫离

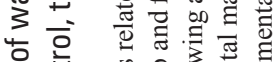

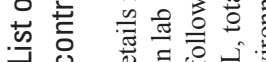

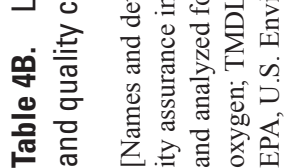

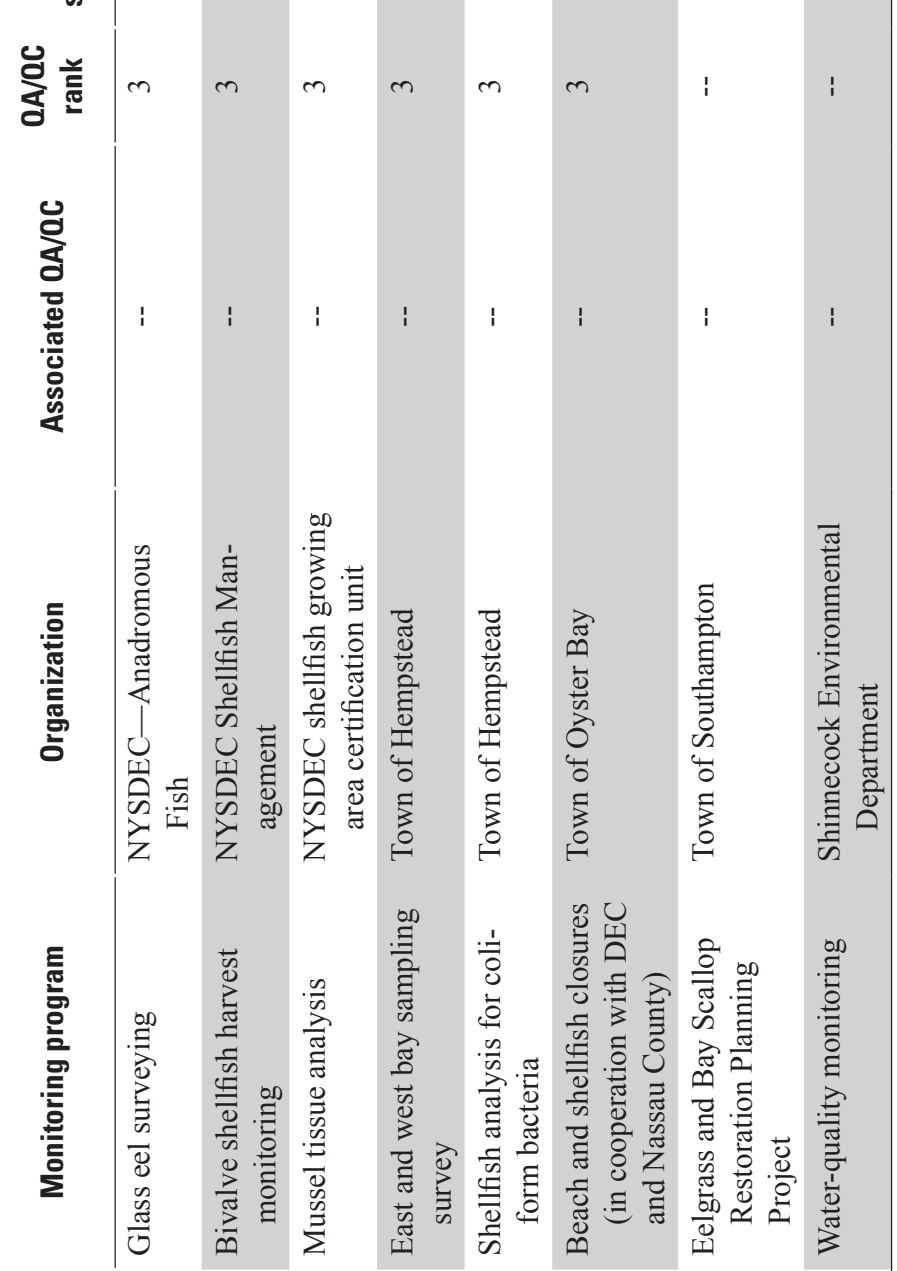


Appendixes 1-5 



\section{Appendix 1. Updates to Recommendations Presented in the 2000 Coordinated Water Resources Monitoring Strategy}

The statuses of recommended improvements presented in the appendix tables of the 2000 Long Island South Shore Estuary Reserve Coordinated Water Resources Monitoring Strategy (CWRMS) to the then-current monitoring programs within the South Shore Estuary Reserve have been checked and are presented in the following tables. The status of each recommendation has been marked as either "Not done," "Partially done," "Done," or "Unknown" on the basis of conversations with responsible agencies (when available). Links to information about the programs that have been implemented are also provided under "Source."

\section{References Cited}

Abbene, I.J., 2010, Shallow groundwater quality in the Village of Patchogue, Suffolk County, New York: U.S. Geological Survey Scientific Investigations Report 2010-5132, 19 p., accessed June 6, 2017, at http://pubs.usgs.gov/ $\operatorname{sir} / 2010 / 5132 /$.

Bricelj, V.M., 2009, The Hard Clam Research InitiativeFactors controlling Mercenaria mercenaria populations in South Shore bays of Long Island, NY: Sea Grant New York NYSGI-T-09-001, 7 p., accessed July 3, 2017, at http://www.seagrant.sunysb.edu/hclam/pdfs/HardClamsExecSum_Conclusions09.pdf.

Cartwright, R.A., and Schubert, C.E., 2016, South Shore Estuary Reserve total maximum daily load monitoring: U.S. Geological Survey dataset, accessed July 3, 2017, at https://www.sciencebase.gov/catalog/ item/560155fde4b03bc34f544447.

CBS New York, 2013, Federal Sandy aid to fund dredging, beach replenishment on Long Island's South Shore: CBS Broadcasting, February 4, 2013, accessed June 21, 2017, at http://newyork.cbslocal.com/2013/02/04/federal-sandyaid-to-fund-dredging-beach-replenishment-on-long-islandssouth-shore/.

Makarewicz, J.C., and Lewis, T.W., 2000, Nutrient and sediment loss from Oneida Lake tributaries-The South Shore tributaries: State University of New York-The College at Brockport, Studies on Water Resources of New York State and the Great Lakes, Technical Reports, paper 84, 54 p., accessed July 3, 2017, at http://digitalcommons.brockport. edu/tech_rep/84.
Mullaney, J.R., and Schwarz, G.E., 2013, Estimated nitrogen loads from selected tributaries in Connecticut draining to Long Island Sound, 1999-2009: U.S. Geological Survey Scientific Investigations Report 2013-5171, 65 p., accessed July 3, 2017, at http://dx.doi.org/10.3133/sir20135171.

New York State Department of Environmental Conservation, 2008, Carmans River biological assessment: New York State Department of Environmental Conservation biological stream assessment, $46 \mathrm{p}$.

New York State Department of Environmental Conservation, 2016, Great South Bay/Fire Island Inlet watershed: New York State Department of Environmental Conservation water-quality assessment, 71 p., accessed June 21, 2017, at http://www.dec.ny.gov/docs/water pdf/wiatllisgsbfii.pdf.

Stephenson, L.B., 2009, Eelgrass management plan for the Peconic Estuary_Peconic Estuary Program: Peconic Estuary Program, 92 p., accessed January 19, 2018, at https://www.peconicestuary.org/wp-content/ uploads/2017/06/EelgrassManagementPlanforthePec.pdf.

Stony Brook University School of Marine and Atmospheric Sciences, 2016, Sea conditions at Shinnecock Inlet: LIShore web page, accessed December 20, 2016, at http://www.lishore.org/shinnecock/latest.php.

Stony Brook University School of Marine and Atmospheric Sciences, 2017, Sea conditions at Shinnecock Inlet: LIShore web page, accessed July 3, 2017, at http://www.lishore.org/ shinnecock/latest.php.

U.S. Army Corps of Engineers New York District, 2004, Atlantic coast of Long Island, Fire Island Inlet to Montauk Point, New York - Reformulation study - Submerged aquatic vegetation (SAV) bed characterization: U.S. Army Corps of Engineers final report, 83 p. plus appendixes.

U.S. Geological Survey, 1999, Simulation of the effects of development of the ground-water flow system of Long Island, New York: U.S. Geological Survey Water-Resources Investigations Report 98-4069, 57 p. [Also available at https://pubs.er.usgs.gov/publication/wri984069.] 


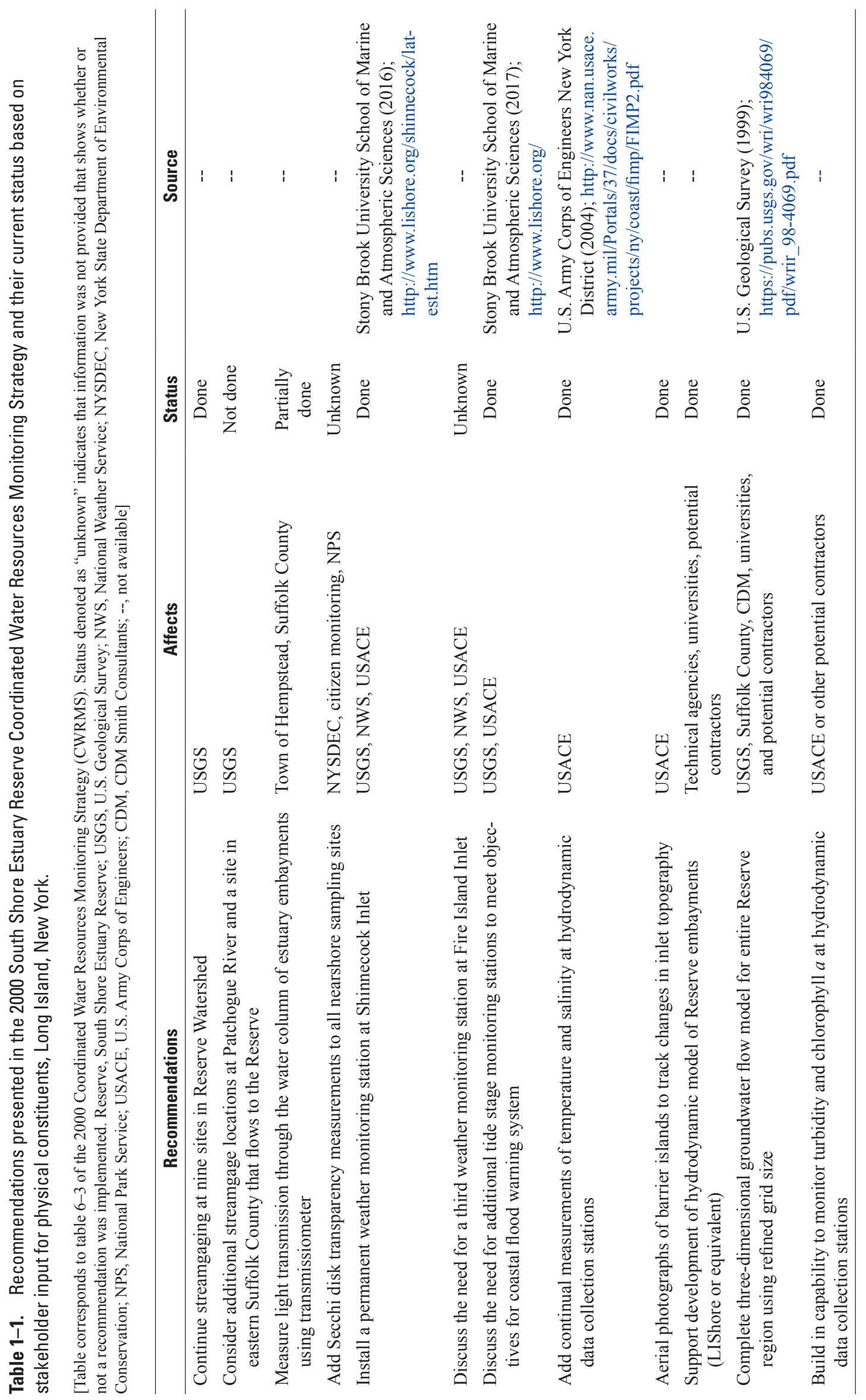




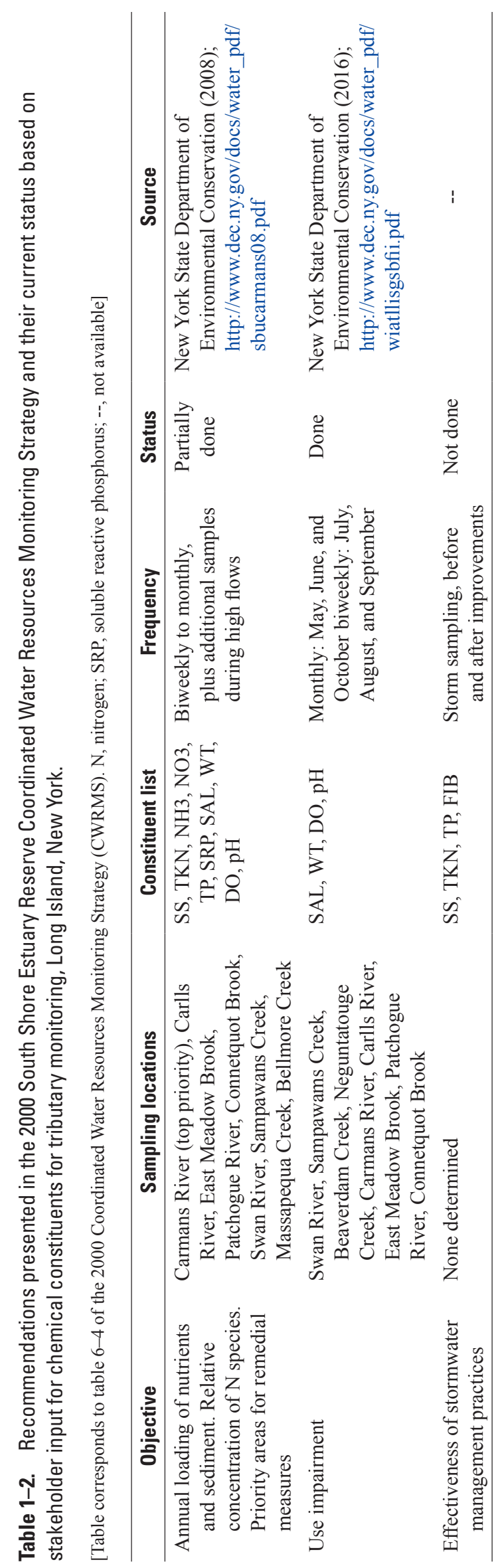




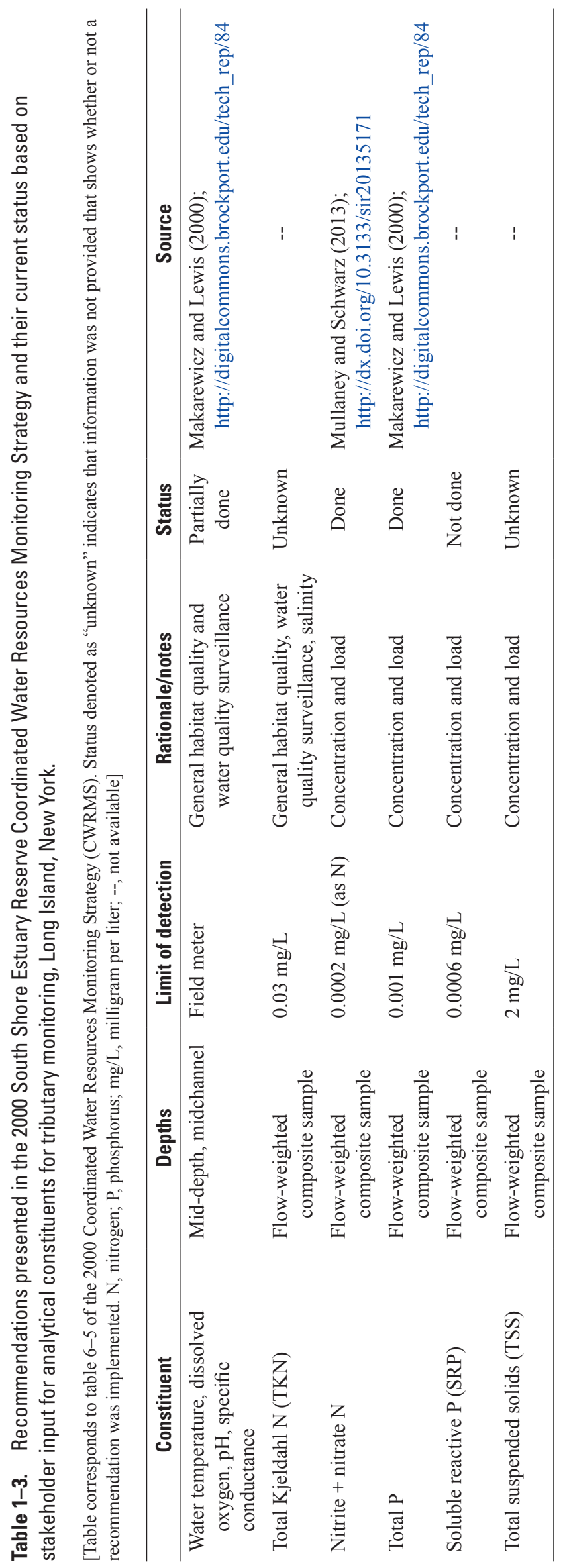




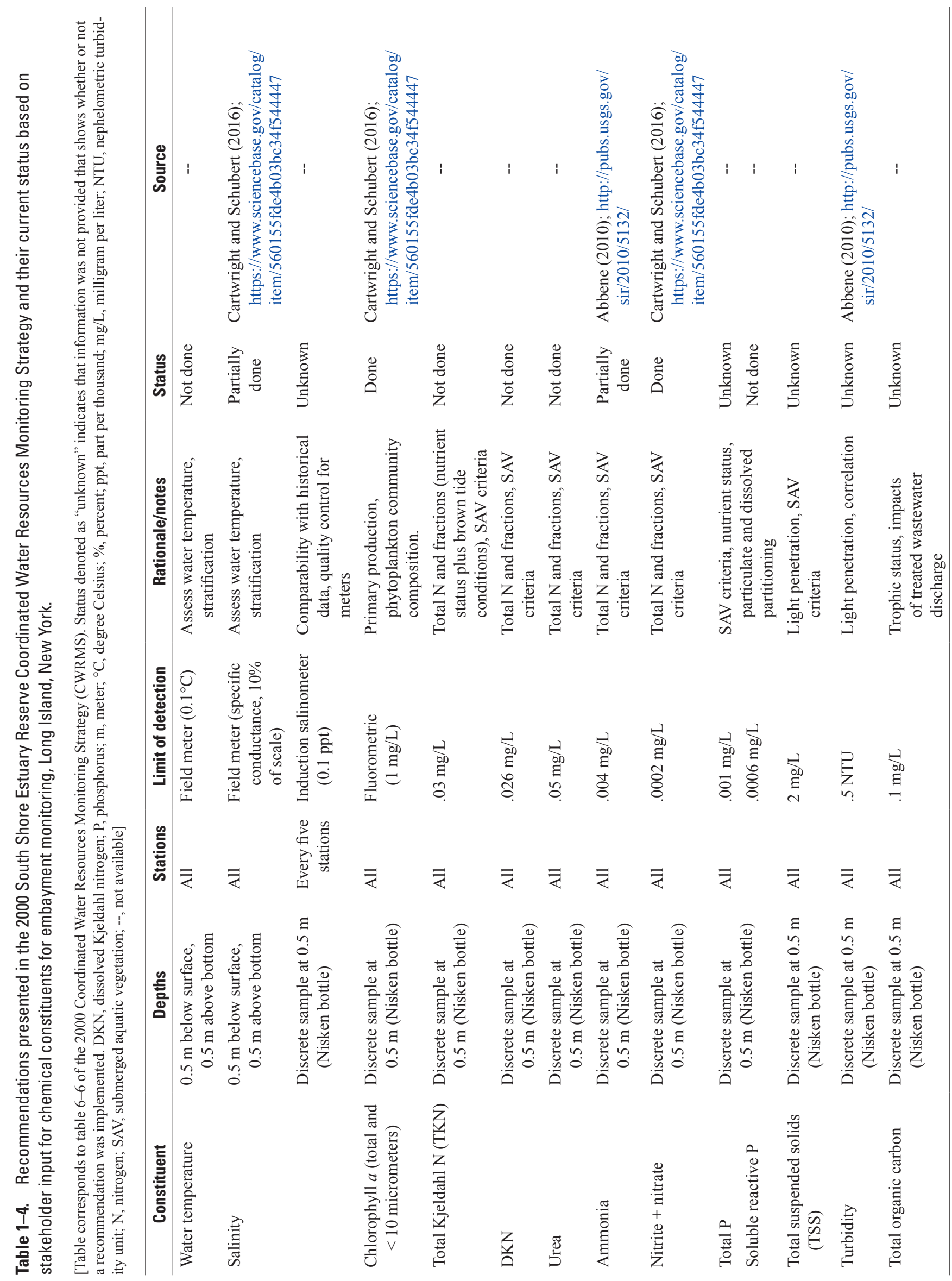




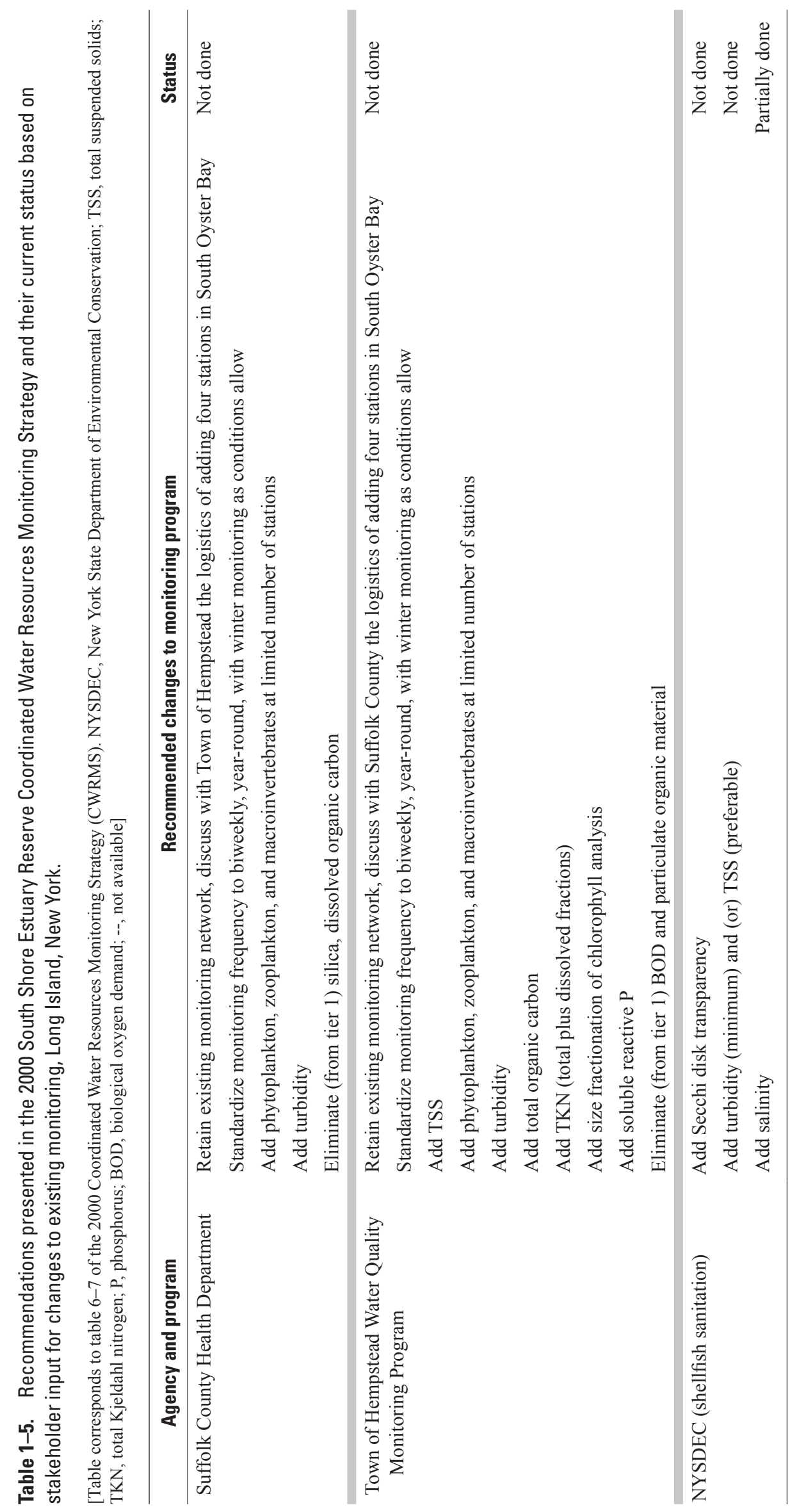


Appendix $1 \quad 77$

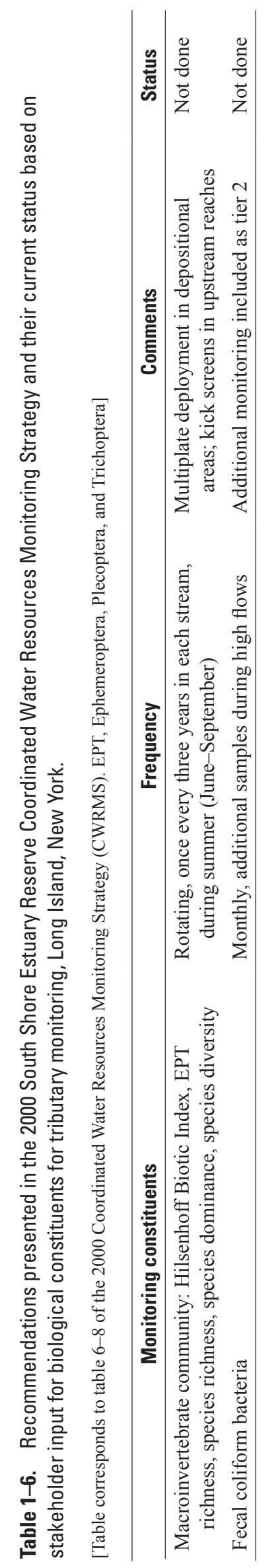




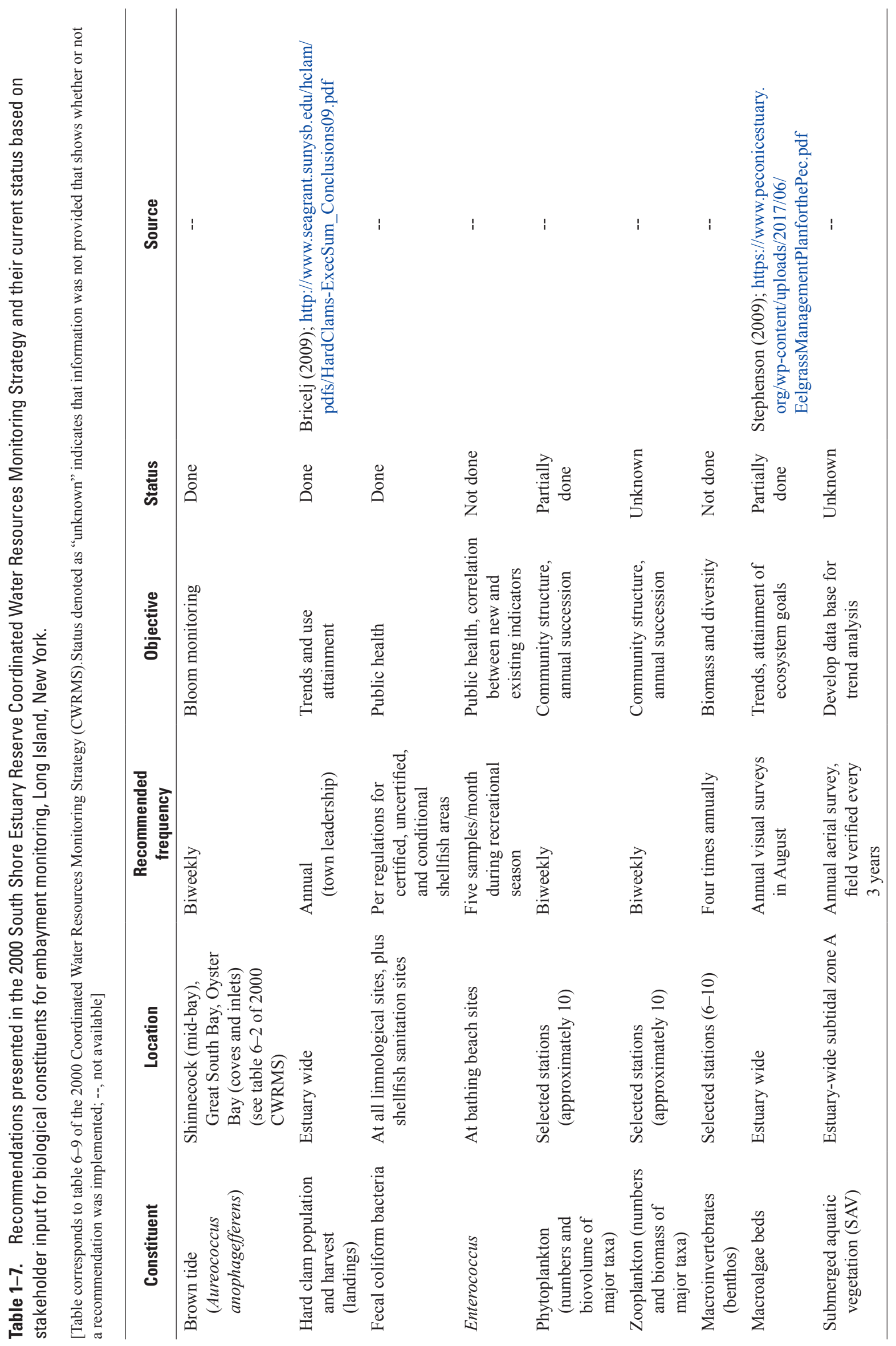




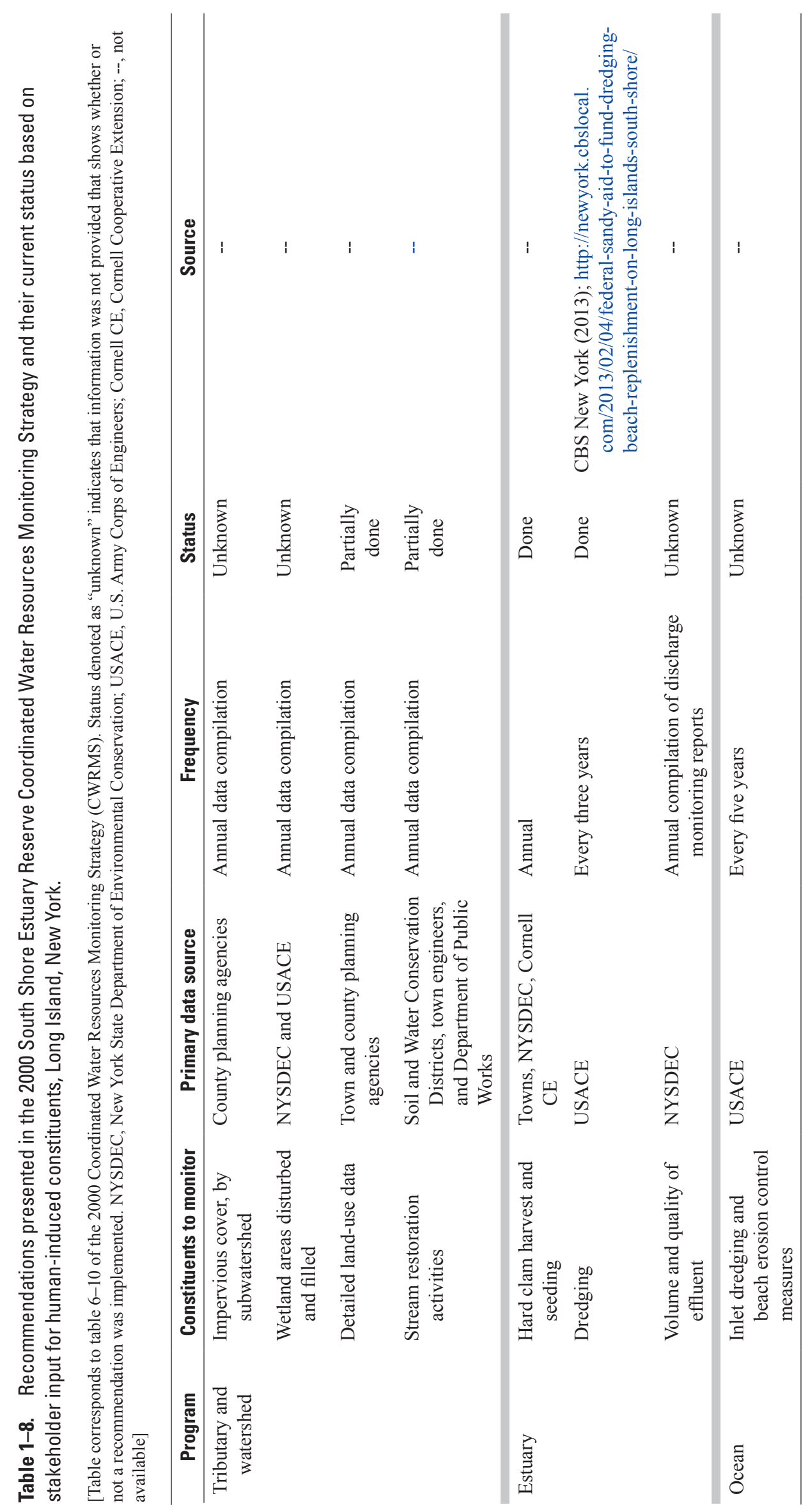



Appendix 2. New York State Department of Environmental Conservation 303(d) List of Impaired Waters 


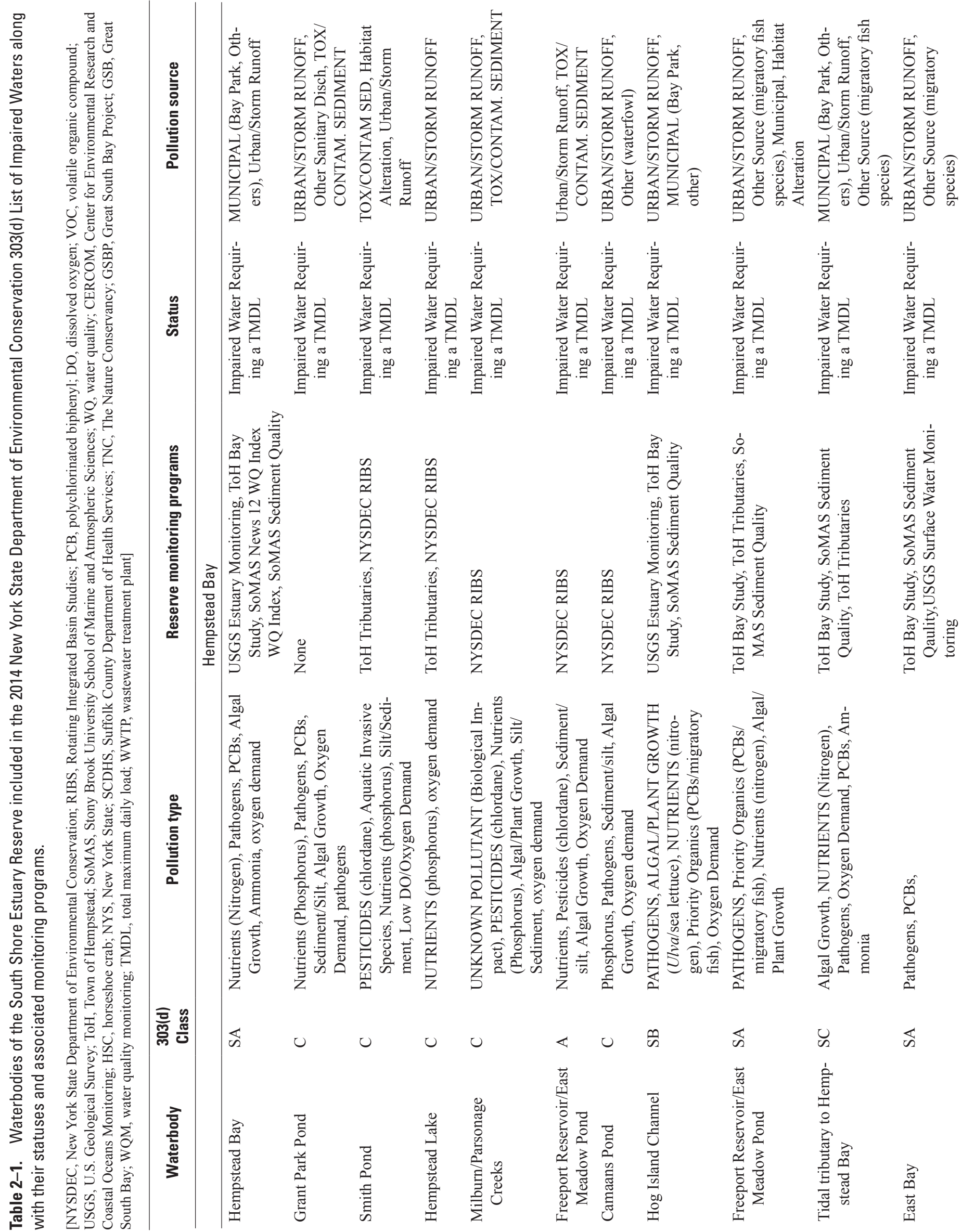




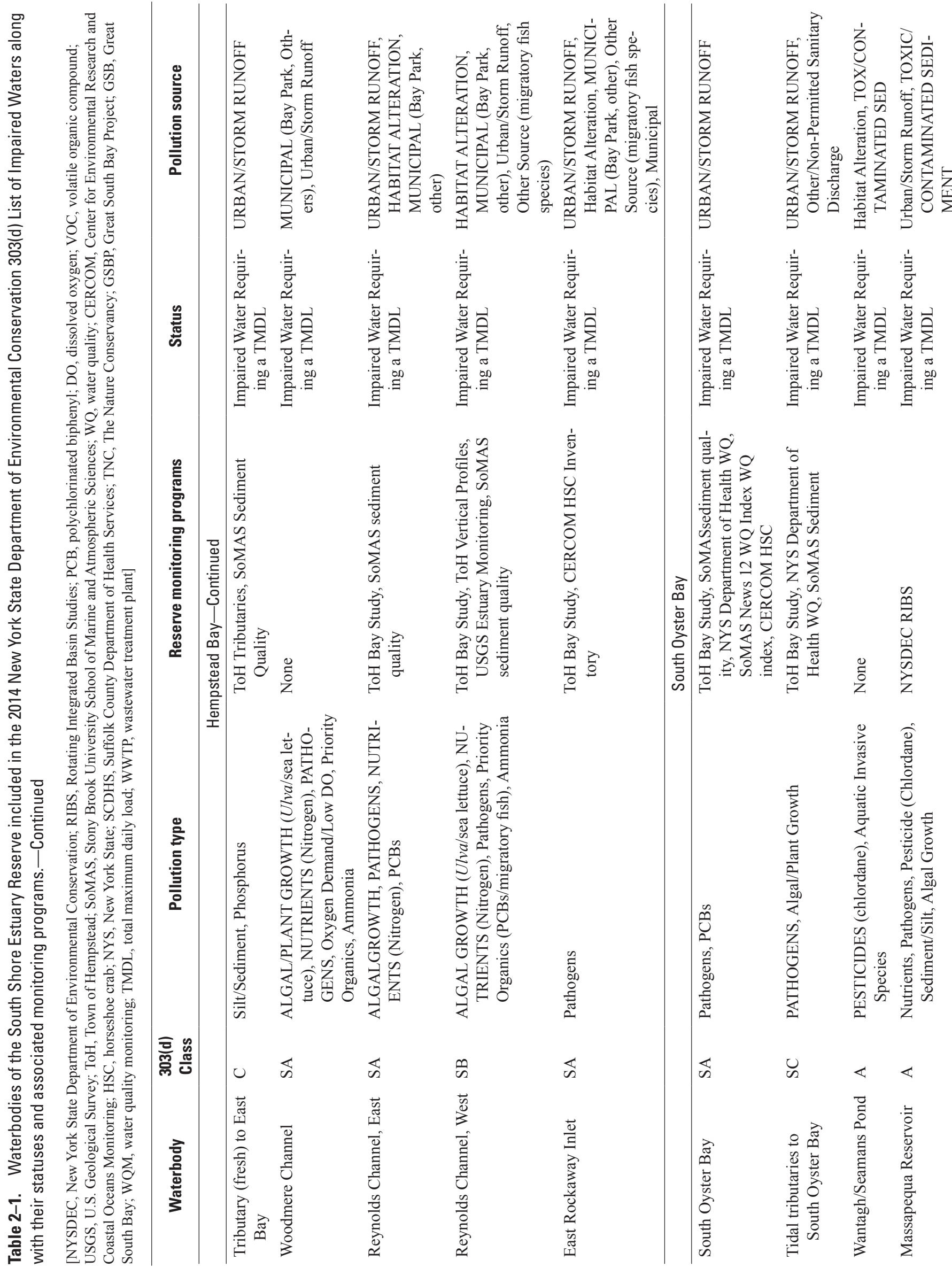



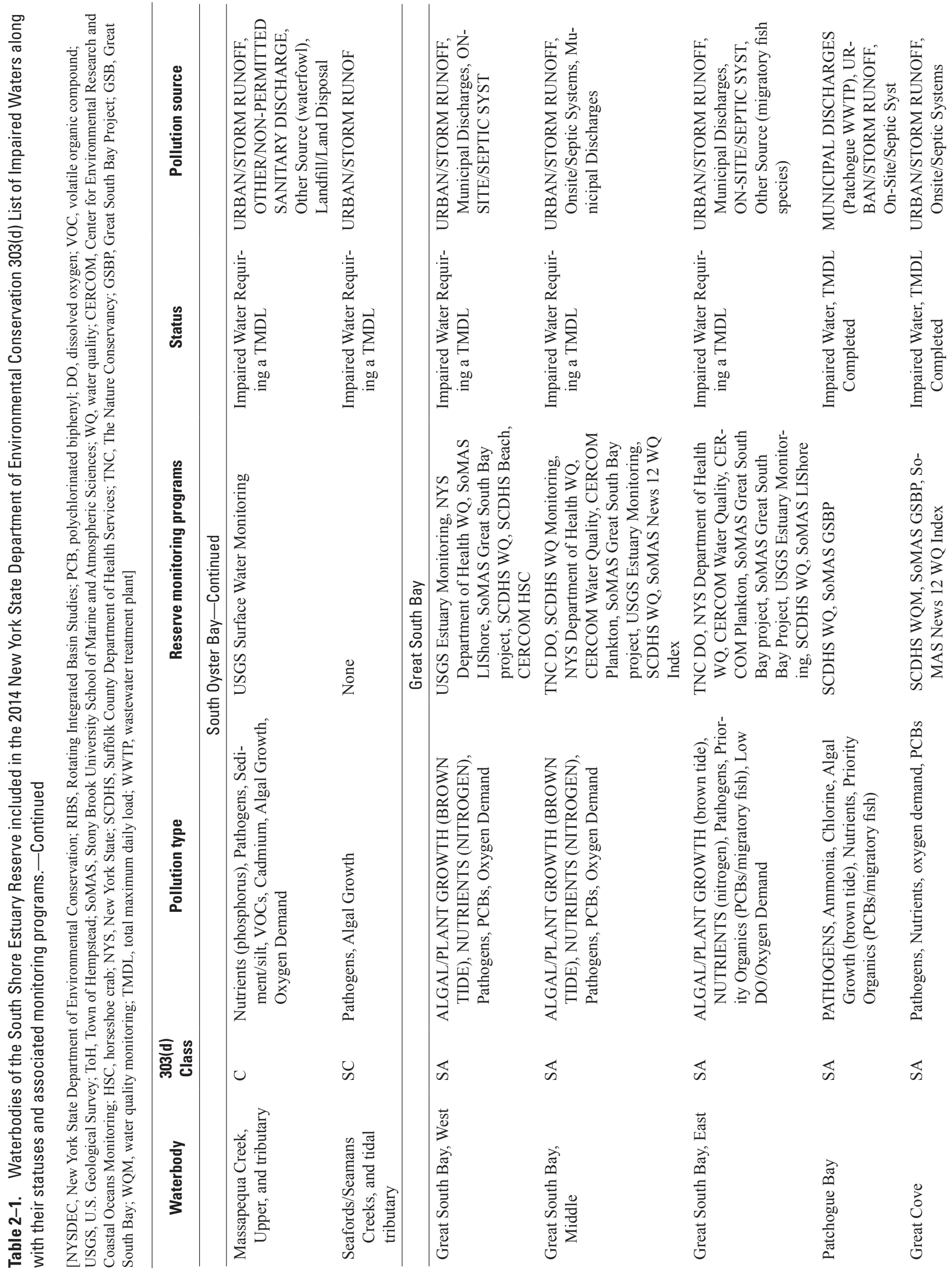

$\underset{\sim}{\longleftarrow}$

$\underset{\sim}{\mathscr{S}}$

岕 药

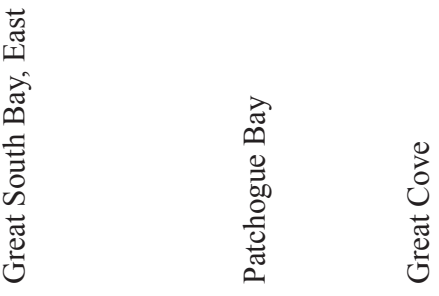




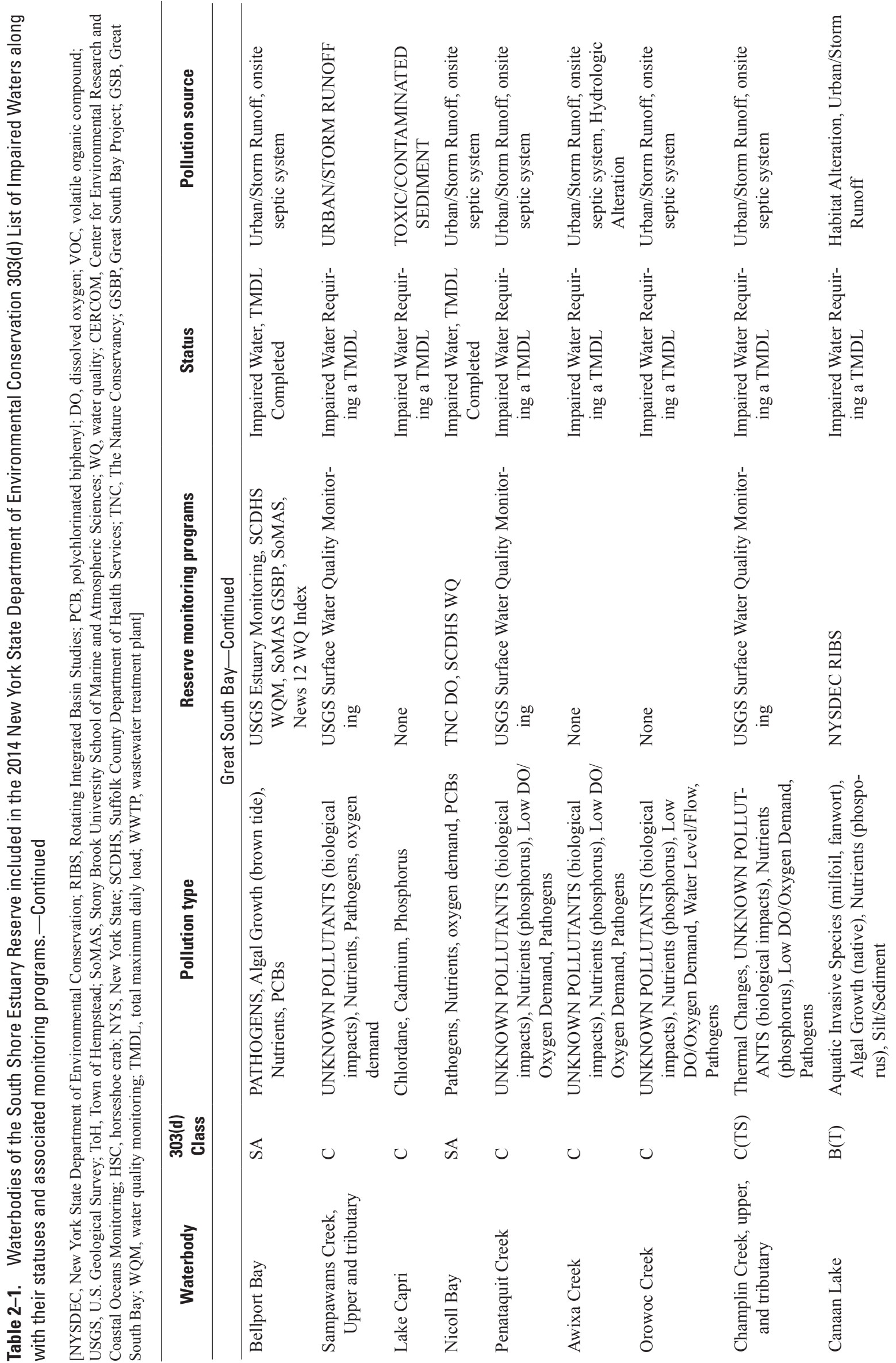



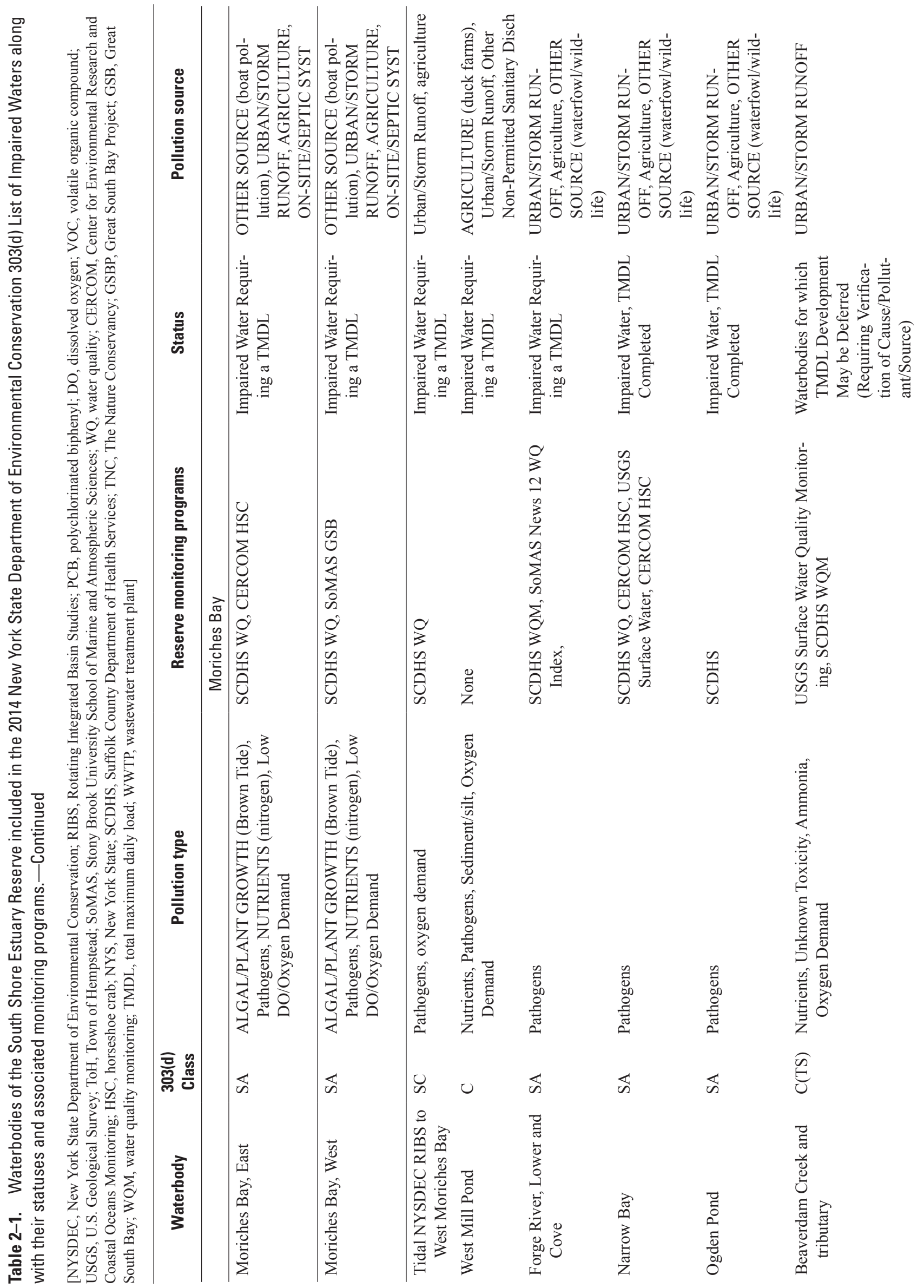


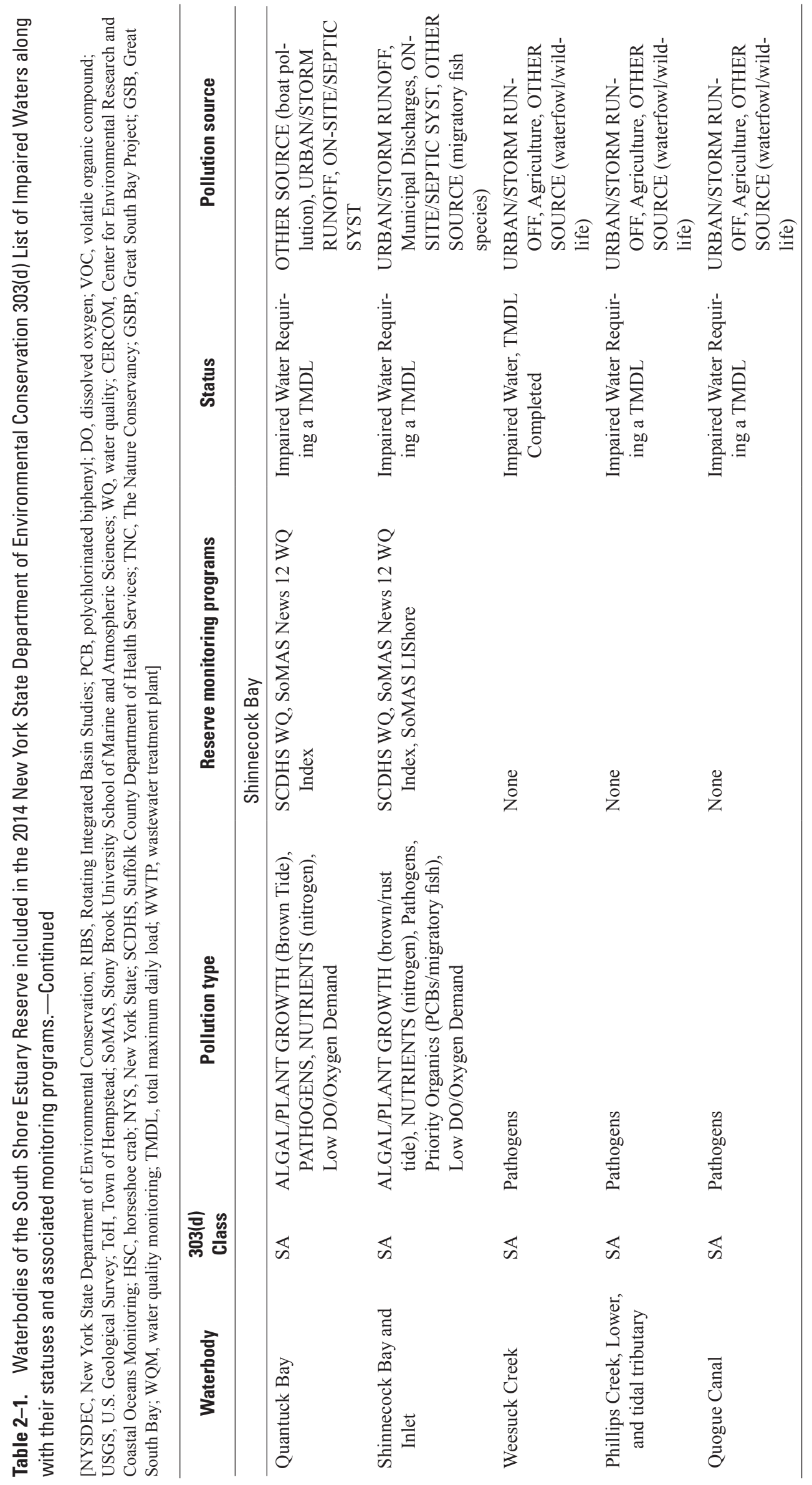



Appendix 3. Expanded List of Management Plans Created or in Progress for Resources Within the Long Island South Shore Estuary Reserve, New York 


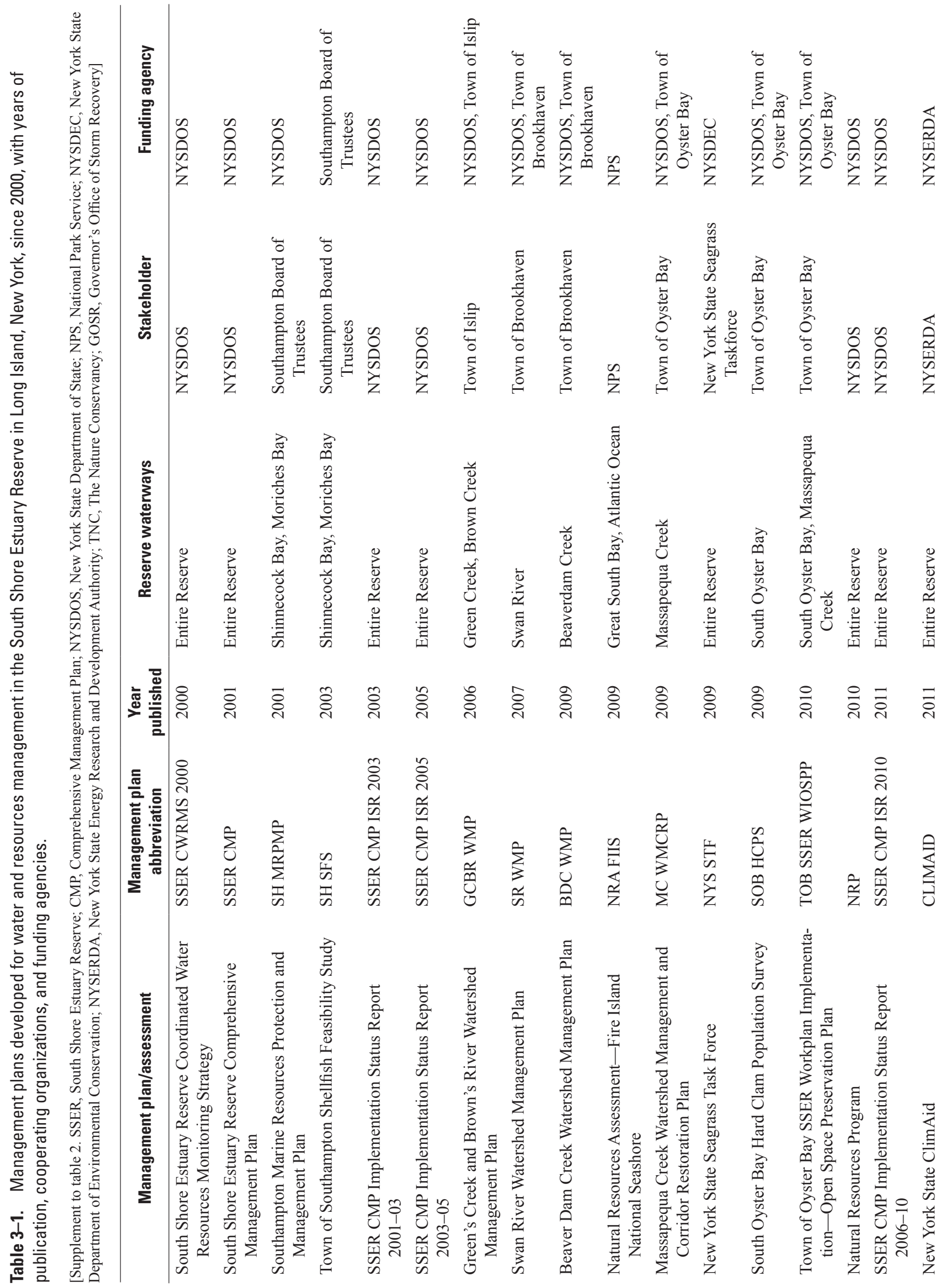




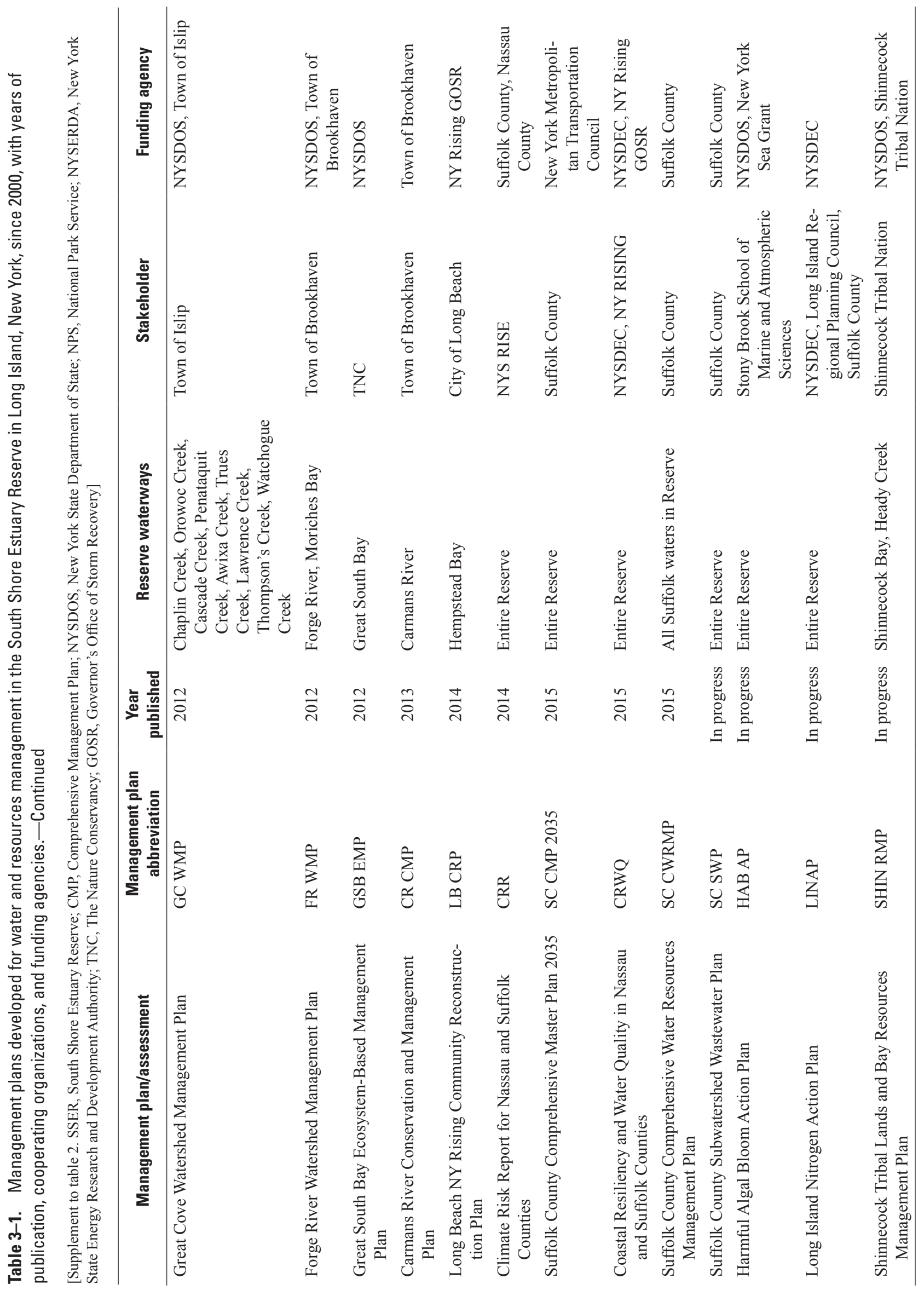



Appendix 4. Members of the Project Advisory Committee for the Long Island South Shore Estuary Reserve 2017 Coordinated Water Resources Monitoring Strategy 
Table 4-1. Contributors to the meetings at which recommendations were presented for the creation of this document.

[SoMAS, Stony Brook University School of Marine and Atmospheric Sciences; EPA, U.S. Environmental Protection Agency; NYSDEC, New York State Department of Environmental Conservation; NYS OPRHP, New York State Office of Parks, Recreation and Historic Preservation; NPS, National Park Service; TNC, The Nature Conservancy; FWS, U.S. Fish and Wildlife Service; USACE, U.S. Army Corps of Engineers]

\begin{tabular}{|c|c|c|c|}
\hline Name & Title & Organization & Email \\
\hline Darvene Adams & Regional Monitoring Coordinator & EPA & adams.darvene@epa.gov \\
\hline Sarah Adams-Schoen & $\begin{array}{l}\text { Assistant Professor of Law and Director of } \\
\text { the Institute on Land Use and Sustainable } \\
\text { Development Law }\end{array}$ & Touro Law School & sadams-schoen@tourolaw.edu \\
\hline Gilbert Anderson & Commissioner & Suffolk County & Brielle.Liere@suffolkcountyny.gov \\
\hline Ken Arnold & Sanitary Engineer & Nassau County & karnold@nassaucountyny.gov \\
\hline Seth Ausubel & $\begin{array}{l}\text { Chief, New York Watershed Management } \\
\text { Section }\end{array}$ & EPA & Ausubel.Seth@epa.gov \\
\hline Rick Balla & Chief, Watershed Management & EPA & balla.richard@epa.gov \\
\hline Bret Bennington & Professor of Geology & Hofstra University & geojbb@hofstra.edu \\
\hline Vince Biondo & Bay Management Specialist & Town of Babylon & vbiondo@townofbabylon.com \\
\hline Lorne Birch & Planner & Town of Hempstead & lornbir@TOHmail.org \\
\hline Henry Bokuniewicz & Distinguished Service Professor & SoMAS & Henry.Bokuniewicz@stonybrook.edu \\
\hline Betty Borowsky & President & South Shore Audubon Society & bborow@optonline.net \\
\hline Patti Bourne & Director Economic Development & City of Long Beach & pbourne@longbeachny.gov \\
\hline Alison Branco & Program Director & Peconic Estuary Program & Alison.Branco@suffolkcountyny.gov \\
\hline Marshall Brown & Director & Save the Great South Bay & marshall@savethegreatsouthbay.org \\
\hline Bruce Brownawell & Associate Professor & SoMAS & bruce.brownawell@stonybrook.edu \\
\hline James Browne & Conservation Biologist & Town of Hempstead & ecojimb@gmail.com \\
\hline Stuart Buckner & Director of Environmental Services & Town of Islip & sbuckner@townofislip-ny.gov \\
\hline Marty Byrnes & Great Atlantic Shellfish Hatchery Supervisor & Great South Bay Hatchery & orders@GSBHatchery.com \\
\hline Tom Carrano & Waterways Manager & Town of Brookhaven & tcarrano@brookhaven.org \\
\hline Frank Castelli & Environmental Projects Coordinator & Suffolk County & frank.castelli@suffolkcountyny.gov \\
\hline Beth Christensen & Associate Professor & Adelphi University & Christensen@adelphi.edu \\
\hline Joe Davenport & $\begin{array}{l}\text { Chief Sanitary Engineer Unit Head, } \\
\text { Water/Wastewater Engineering Unit } \\
\text { Nassau County Department of Public Works }\end{array}$ & Nassau County & jdavenport@nassaucountyny.gov \\
\hline Walter Dawydiak & Division Director of Environmental Quality & Suffolk County & Walter.Dawydiak@suffolkcountyny.gov \\
\hline Mary Dempsey & Vector Control, Biologist & Suffolk County & Mary.dempsey@suffolkcountyny.gov \\
\hline Charles de Quillfeldt & Biologist, Bureau of Marine Resources & NYSDEC & Charles.DeQuillfeldt@dec.ny.gov \\
\hline $\begin{array}{l}\text { Maureen Dolan } \\
\text { Murphy }\end{array}$ & Chair, Executive Programs Manager & $\begin{array}{l}\text { Citizens Campaign for the } \\
\text { Environment }\end{array}$ & mmurphy@citizenscampaign.org \\
\hline Adrienne Esposito & Executive Director & $\begin{array}{l}\text { Citizens Campaign for the } \\
\text { Environment }\end{array}$ & aesposito@citizenscampaign.org \\
\hline Joe Febrizio & Deputy Commissioner of Public Works & City of Long Beach & jfebrizio@longbeachny.gov \\
\hline Lauretta Fischer & Chief Environmental Analyst & Suffolk County & lauretta.fischer@suffolkcountyny.gov \\
\hline Charles Flagg & Research Professor & SoMAS & Charles.Flagg@stonybrook.edu \\
\hline Brian X. Foley & Deputy Regional Director for Long Island & NYS OPRHP & Brian.Foley@parks.ny.gov \\
\hline Aaren Freeman & Associate Professor & Adelphi University & afreeman@adelphi.edu \\
\hline Sharon Frost & $\begin{array}{l}\text { Soil and Water Conservation District Techni- } \\
\text { cian }\end{array}$ & Suffolk County & Sharon.Frost@suffolkcountyny.gov \\
\hline Dan Fucci & Hydrogeologist Department of Public Works & Nassau County & dfucci@nassaucountyny.gov \\
\hline Sandra Garren & $\begin{array}{l}\text { Assistant Professor of Geology, Environment, } \\
\text { and Sustainability }\end{array}$ & Hofstra University & sandra.j.garren@hofstra.edu \\
\hline Chris Gobler & Associate Professor & SoMAS & Christopher.Gobler@stonybrook.edu \\
\hline Anthony Graves & Environmental Analyst & Town of Brookhaven & agraves@brookhaven.org \\
\hline Jeffrey Greenfield & Chair, Nassau County Planning Commission & Nassau County & jgreenfield@nassaucountyny.gov \\
\hline Rich Groh & Principal Environmental Analyst & Town of Babylon & rgroh@townofbabylon.com \\
\hline
\end{tabular}


Table 4-1. Contributors to the meetings at which recommendations were presented for the creation of this document.-Continued

[SoMAS, Stony Brook University School of Marine and Atmospheric Sciences; EPA, U.S. Environmental Protection Agency; NYSDEC, New York State Department of Environmental Conservation; NYS OPRHP, New York State Office of Parks, Recreation and Historic Preservation; NPS, National Park Service; TNC, The Nature Conservancy; FWS, U.S. Fish and Wildlife Service; USACE, U.S. Army Corps of Engineers]

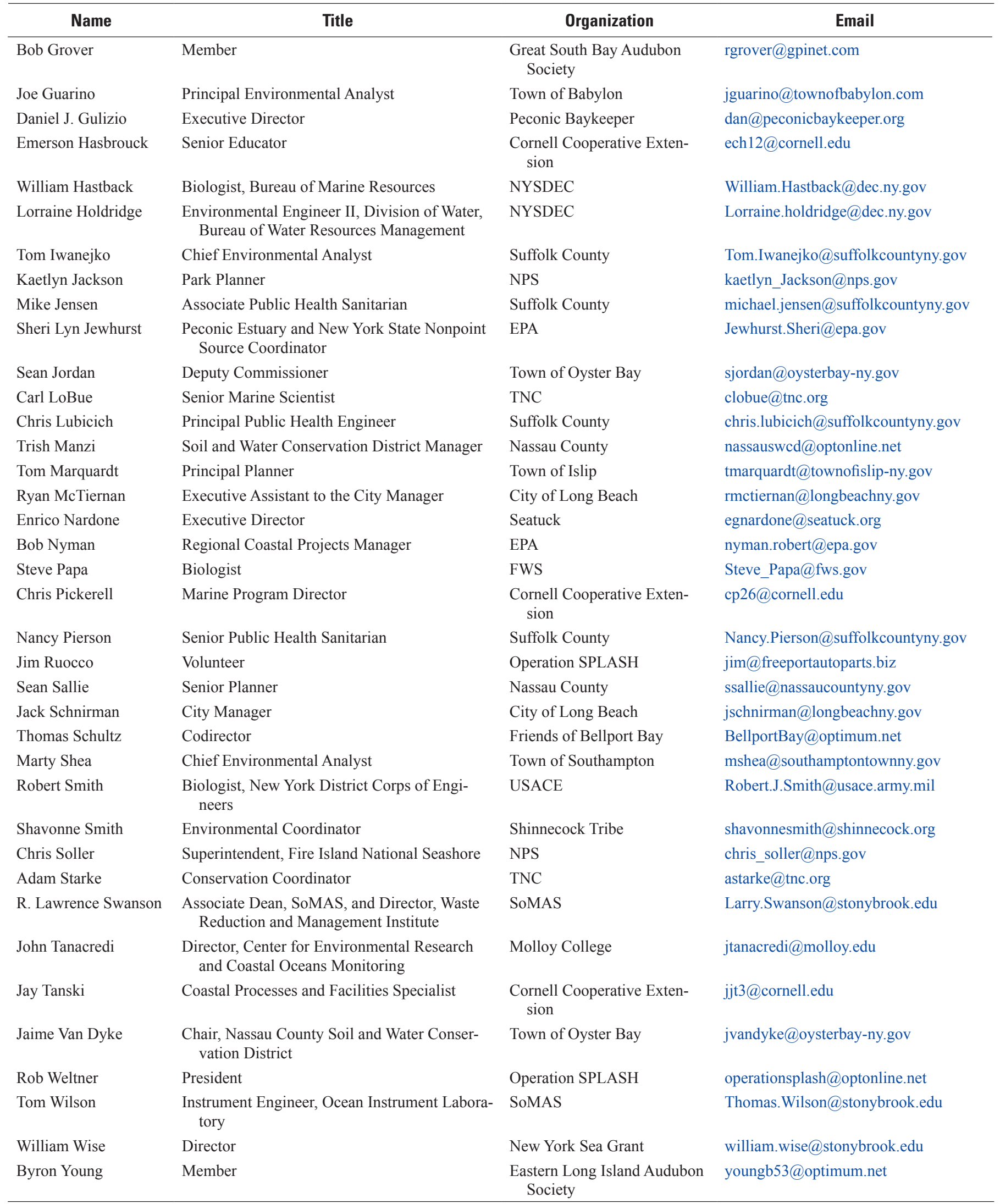





\title{
Appendix 5. Notes From the South Shore Estuary Reserve Coordinated Water Resources Management Strategy Project Advisory Committee Meetings
}

\author{
South Shore Estuary Reserve Coordinated Water Resources Monitoring Strategy Update \\ Project Advisory Committee Meeting \#1 Notes \\ Town of Babylon, Department of Parks and Recreation Building \\ 151 Phelps Lane, North Babylon, NY \\ Thursday, February 5, 2015 (Snow Date, February 6, 2015)—9:30 a.m.-3:15 p.m.
}

U.S. Geological Survey-Shawn Fisher and Chris Schubert

New York State Department of State Office of Planning and Development and the South Shore Estuary Reserve Office-

Nancy Rucks, Myra Fedyniak, Sherry Forgash, and Lou Siegel

The first South Shore Estuary Reserve (SSER) Coordinated Water Resources Monitoring Strategy (CWRMS) Update Project Advisory Committee (PAC) meeting was held at the Town of Babylon Parks and Recreation building and included members of the PAC (table 4-1) and other SSER stakeholders. The meeting's objective was to bring together Federal, State, Tribal, and local governments; academic institutions; and nonprofit organizations for an informed discussion about how the surface water and groundwater within the SSER watershed have changed since the first CWRMS was compiled in 2000. Through an agreement between the New York State Department of State Office of Planning and Development (NYSDOS) and the U.S. Geological Survey (USGS) that commenced in October 2014, the USGS will prepare a CWRMS update by 2016 and create a CWRMS website with an interactive mapper, which will spatially display water-quality monitoring sites and access water-quality data through the Water Quality Portal (https://www.waterqualitydata.us/). Data and other pertinent information for this project will primarily be solicited from entities and individuals with water-quality and (or) ecological expertise in the SSER through a series of meetings with the PAC, surveys, a regional workshop, and interviews with governmental agencies, academic institutions, and nonprofit organizations.

Rich Groh, of the Town of Babylon and a long-standing SSER partner, welcomed the group to the PAC meeting. Following a round of introductions, S. Fisher presented slides and gave a brief explanation of why the CWRMS is in need of a revision, the objectives of the agreement, and the role of the PAC. As the presentation progressed, discussion of issues related to SSER water quality in the past 15 years was facilitated to identify and focus the concerns of the PAC. A group discussion followed and identified topics that need to be covered in the CWRMS update. These PAC discussion topics include

- Groundwater influence to the Reserve bays

- Inadequate onsite wastewater treatment systems leading to contaminated groundwater (particularly of concern near the coast)
- Larger sources of nitrogen and other contaminants than previously thought

- Potential sources of pathogens

- Total maximum daily loads (TMDLs)

- Constituents

- Status of existing TMDLs being prepared

- Timelines for completing TMDLs for bays and tributaries

- Wastewater

- Point sources such as sewage treatment plant outfalls and discharges from illicit wastewater hook-ups

- Nonpoint sources such as overland flow to the bays and contributions from groundwater seepage

- Infrastructure concerns-failing/collapsing cesspools, leaking sewage lines, especially from private hookups to municipal lines

- Stormwater treatment/retention

- Nassau County Bay Park Sewage Treatment Plant and others that discharge to SSER waters

- Suffolk County Southwest Sewer District (Bergen Point) and other plants that discharge to the Atlantic Ocean

- Sediment

- Physical and chemical data are lacking

- Surface elevation tables (salt marshes)

- Transport

- Water quality of the bays, tributaries, and contributing groundwater 
- Nutrients

- Pesticides/herbicides

- Petroleum and other organic pollutants

- Pathogens

- Beach and shellfishing closures

- Phytoplankton surveys and harmful algal blooms

- TMDLs

- Personal care products

- Wildlife

- Shellfish monitoring and restoration

- Finfish surveys

- Birds/waterfowl inventory

- Horseshoe crab inventory

- Climate change

- Increased frequency of extreme weather events

- Sea-level rise

- Increased frequency and height of storm surges

- Increased localized spring-tide flooding

- Ocean acidification

- Shoreline resiliency-natural and built

- Salt marshes

- Submerged aquatic vegetation

- Invasive plants

- Vulnerable infrastructure near the shore such as home heating, fuel tanks, and septic tanks/cesspools

- Inventory of marinas

- Dredging

- Hurricane Sandy

- Effects on water and sediment quality

- Effects on the built environment

- Rebuilding — dunes, wetlands, homes, marinas, wastewater infrastructure, and transportation infrastructure

- Aftermath and looking forward

- Tidal wetland loss
- Spills, contaminants, and floatables databases and inventories

- Dredging

- Potential effect of regional projects on water quality, including New York Rising Community Reconstruction Plan projects, Rebuild by Design project in Mill River (East Rockaway), and Suffolk County sewer system upgrades

The group discussed the type and availability of data to begin making connections between the topics for the CWRMS update and how those data will be referenced and displayed on the CRWMS interactive mapper. Each PAC member identified one or more sources of data and how/where they are being stored. Some of the organizations that have collected and stored data pertaining to the SSER were identified as follows:

- U.S. Environmental Protection Agency (EPA)

- U.S. Geological Survey

- U.S. Army Corps of Engineers

- U.S. Fish and Wildlife Service

- National Park Service-Fire Island National Seashore

- National Oceanic and Atmospheric Association

- New York State Department of Environmental Conservation

- New York State Office of Parks, Recreation, and Historic Preservation

- Nassau County

- Suffolk County

- Cornell Cooperative Extension of Suffolk County

- Town of Hempstead

- Town of Babylon

- Town of Southampton

- The Nature Conservancy

- Stony Brook University-School of Marine and Atmospheric Sciences

- Molloy College

- Operation SPLASH

- American Littoral Society

- Adelphi University

- Other citizen science organizations 
Using a Microsoft PowerPoint presentation, S. Fisher illustrated each SSER CWRMS proposed web page and its content. The website will embed the Water Quality Portal mapper, which queries the Water Quality Exchange (WQX; a search engine of both the EPA Storage and Retrieval [STORET] and USGS National Water Information System [NWIS] databases). Many topics and data types outlined above were suggested for inclusion as layers or data points. As the website develops, USGS will work with the PAC to design the pages, which will include a PAC member-only page (requiring login) that will host all meeting documents, a forum, and PAC-related updates.

An SSER CWRMS update workshop has been scheduled for May 28, 2015, at Farmingdale State College, Farmingdale, New York, and a draft agenda was shared with the PAC. Tentatively, there will be a keynote speaker in the morning (Judith Enck, EPA Region 2, was suggested), followed by presentations by USGS, NYSDOS, and other stakeholders to provide context for the SSER CWRMS update, the current status of SSER water-quality and monitoring activities, and the importance of stakeholder input. A series of breakout sessions will generate discussion about pertinent topics. The results from the workshop will help identify the most important topics for the CWRMS update.

The PAC meeting was successful in assembling most of the relevant stakeholders who closely monitor the SSER to discuss pressing issues facing the SSER bays, tributaries, and groundwater. A follow-up meeting for those who were unable to attend is being scheduled for March 19, 2015, and interviews with water-quality practitioners will be held on an individual basis in the coming months. A date for the second PAC meeting is to-be-determined - and may be held a few weeks before the workshop.

\title{
South Shore Estuary Reserve Coordinated Water Resources Monitoring Strategy Update Project Advisory Committee Meeting \#1-A Notes State Office Building, Basement Classroom 250 Veterans Memorial Highway, Hauppauge, NY Thursday, March 19, 2015-9:00 a.m.-12:00 p.m.
}

\author{
U.S. Geological Survey-Shawn Fisher and Chris Schubert \\ New York State Department of State Office of Planning and Development Office-Nancy Rucks and Myra Fedyniak; \\ Long Island South Shore Estuary Reserve Office-Sherry Forgash and Lou Siegel \\ PAC Members \\ The meeting began at 9:15 a.m.
}

This was the second meeting of the South Shore Estuary Reserve (SSER) Coordinated Water Resources Monitoring Strategy (CWRMS) Project Advisory Committee (PAC). The objective of the meeting was to bring together Federal, State, Tribal, and local government agencies, academic institutions, and, nonprofit organizations that were unable to attend the first PAC meeting on February 5, 2015. Development of the new CWRMS and monitoring information repository (website/ mapper) commenced in October 2014 through an agreement between the New York State Department of State (NYSDOS) Office of Planning and Development and the U.S. Geological Survey (USGS).

Using a Microsoft PowerPoint presentation, S. Fisher explained the new CWRMS project, the agreement tasks, and the role of the PAC. As the presentation progressed, discussion of issues related to SSER water quality in the past 15 years was facilitated to identify and focus the concerns of the PAC members. This was followed by a discussion of topics for the new CWRMS. The following is a summary of the PAC member discussions:

- Purpose of the CWRMS strategy and website is to create a cohesive, prioritized, user-friendly clearinghouse for environmental data for the SSER and its ground- water contributing area and not just a list of available information

- The NYSDOS is still planning on updating the SSER Comprehensive Management Plan (CMP) in the future

- The SSER Office is currently preparing the SSER CMP Implementation Status Report

- The SSER CMP update will look at potential amendments to the Long Island SSER Act

- Data archiving emerged as a followup project to the CWRMS. Data transferred into the Water Quality Exchange (WQX), which is a search engine that queries both the U.S. Environmental Protection Agency (EPA) Storage and Retrieval (STORET) and USGS National Water Information System (NWIS) databases, will be permanently archived and available for use thereby safeguarding legacy datasets; the type of data, units, and mode of storage need to be addressed

- Data sharing agreements between agencies or academics may be needed 
- The PAC should prioritize how and when information for the CWRMS and the website will be updated

- There are some problems with the WQX in terms of data units - it was suggested that a PAC meeting be held specifically to learn how to work with the WQX

- Types of data that should be entered into the WQX

- Stormwater/wastewater/groundwater data

- Sediment sampling/contamination data

- Sea-level rise data and effect on marshes

- Invasive species data

- Shellfish health data

- Biota inventories

- The CWRMS should have an ecosystem-based management (EBM) focus

- Portions of the Peconic Estuary Program submerged aquatic vegetation management plan that are applicable to the SSER should be included

Available data that should be presented in the CWRMS and (or) the website interactive mapper:

- Utilize the Long Island Geographic Information Systems User Group, data.gov, and Sea Grant (searchable database for legacy studies) for data and information

- Open space and land-use datasets (for lands surrounding the SSER and its tributaries)

- Recreational and commercial loadings (fishing) data

- Monitoring data on marsh restoration projects

- Data on capital improvement projects (such as those funded by the New York Rising Community Reconstruction Program and U.S. Army Corps of Engineers [USACE])

- Bird data (such as nesting Saltmarsh Sparrow data from the U.S. Fish and Wildlife Service [FWS])

- Data from horseshoe crab research and other wildlife monitoring programs

- Tidal wetlands trends analysis data

- Surface elevation tables (for measuring relative sediment elevation changes for tidal marsh monitoring)

- Harmful algal bloom data

- Marine debris data

- Data from sewage treatment plants and public drinking water wells
- Water-quality monitoring data (such as data collected by Stony Brook University School of Marine and Atmospheric Sciences [SoMAS]) in Great South Bay that dates back to 2004 and includes temperature, salinity, chlorophyll, and water level. Real-time data are provided by seven monitoring sites from Tanner Park in Babylon to Smith Point in Brookhaven, a buoy south of Sayville, and the Sea-Bird SeaCat off Bellport. SoMAS also collects data from periodic aerial flights, photomosaics, bathymetric surveys, and nutrient sampling at the Old Inlet breach. There are also USGS real-time water-quality monitoring stations in Hog Island Channel and Reynolds Channel.

- Data from additional nongovernment groups that do citizen monitoring including Trout Unlimited; Operation SPLASH; Coastal Research and Education Society of Long Island (CRESLI), which has a good amount of data, and other organizations collecting data on alewives, seafood, marine debris, and birds. The Seafood Council is another source of information

- Water-quality data from public beaches and closures (State and local)

- Data regarding runoff from stormwater inputs, golf courses, and municipal separate storm sewer system (MS4) information from government agencies

- National Coastal Condition Assessment data (which is completed every 5 years and includes sediment chemistry, fish studies, and discharge monitoring - the Bay Park Sewage Treatment Plant will be included in monitoring efforts this year)

- Studies being completed on the western bays by Queens College

- Sea-level rise (SLR) modeling by CDM-Smith, consultants

- Applicable aquaculture data from the Peconic Estuary Program

- Study of the Grand Canal in Oakdale

- USACE Northeast Coast Comprehensive Study (Nassau County is a potential study site)

- Source Water Assessment Program

- USGS monitoring data (which includes groundwater contributing areas, major streams monitoring, and continuous water-quality monitoring gages (temperature, salinity, total chlorophyll, turbidity, dissolved oxygen, and nitrate). Plans include installing tide gages on barrier side of Great South Bay (Moriches, Shinnecock, and West Sayville). Post-Hurricane Sandy, USGS collected 120,160 samples for metals, polychlorinated biphenyls (PCBs), and dioxin along the New York and 
New Jersey coast and will be starting a new sampling project to collect baseline sediment data from Maine to Virginia.

S. Fisher showed slides of the proposed SSER CWRMS website. The website will embed the Water Quality Portal mapper, which queries both NWIS and STORET. Many topics and data types outlined above were suggested for inclusion as layers or as data points. As the website develops, USGS will work with PAC members to design the pages, which will include a PAC member-only page (requiring login) that will host meeting documents and reports for review, a forum, and PAC-related updates. Adding a key word search to the references section of the website was suggested.

An all-day SSER CWRMS workshop is scheduled for May 28, 2015, at Farmingdale State College, Farmingdale, N.Y. The draft agenda includes a morning keynote speaker, followed by presentations by USGS, NYSDOS, and other stakeholders to provide context for the new SSER CWRMS, the status of SSER water-quality and monitoring activities, and the importance of stakeholder input. A series of breakout sessions in the afternoon will generate discussion about topics pertinent to the SSER. The results from the workshop will help identify available datasets and the most important topics for the new CWRMS. Discussion of the workshop included:

- Topic suggestions for breakout sessions

- Hurricane Sandy (and coastal storms in general)

- Harmful algal blooms, acidification

- Fire Island to Montauk Point (FIMP) Reformulation Study

- Comparing the eastern and western SSER bays

- Poster presentations covering additional topics not discussed by the panelists

USGS will be in contact with PAC members to schedule individual meetings after the CWRMS workshop to gather information that is more specific.

Meeting adjourned at 12:15 p.m.

\title{
South Shore Estuary Reserve Coordinated Water Resources Monitoring Strategy Update Project Advisory Committee Meeting \#2 Notes Touro Law School, Central Islip, NY Friday, September 18, 2015-9:00 a.m.-3:00 p.m.
}

\author{
U.S. Geological Survey-Shawn Fisher and Chris Schubert \\ New York State Department of State Office of Planning and Development Office-Nancy Rucks \\ Long Island South Shore Estuary Reserve Office-Sherry Forgash \\ Project Advisory Committee Members-See attached sign-in sheet for attendees. \\ The meeting began at 9:15 a.m.
}

This was the second all-hands meeting of the South Shore Estuary Reserve (SSER) Coordinated Water Resources Monitoring Strategy (CWRMS) Project Advisory Committee (PAC). The objective of the meeting was to update the PAC on the current status of the CWRMS and demonstrate the website forum feature.

Sarah Adams-Schoen of Touro welcomed the PAC to campus and provided information on logistics for the meeting.

Using a Microsoft PowerPoint presentation, S. Fisher reviewed the highlights of the previous PAC meetings and the CWRMS workshop held at Farmingdale State College on May 29, 2015. The individual stakeholder meetings were mentioned as most have been completed and notes, which will be used to help draft the CWRMS document, have been drafted. There was a brief discussion about how these notes would be used in shaping the document.

Following a discussion of milestones reached thus far, a draft outline for the CWRMS document was presented and the PAC was asked to comment. Each item was reviewed and discussed, with changes made in real time. There were many good suggestions for making the structure of the report better. See the attached revised version of the draft CWRMS outline.
A draft of the "Quality Assurance and Quality Control" (QA/QC) section of the CWRMS report was presented next. Changes were again made in real time, with discussion focused on the level of QA/QC groups (agencies, academics, citizen scientists) are responsible for, how much can be expected of them, and whether they should be following a quality assurance project plan (QAPP) or QAPP-like document regardless of how funding is provided. See the attached revised version of the draft QA/QC section outline.

L. Bonavita gave an interactive demonstration of the CWRMS website and forum. Each page on the public-facing portion of the website was reviewed. The PAC member forum was then introduced as a login-based system for the exchange of documents and conversation related to monitoring in the SSER. As most PAC members had an internet-enabled device, they were able to register and follow along inreal time. Functions such as messaging, creating forum threads, and uploading documents were reviewed, and an instructional pamphlet was provided for future reference. There were several questions and requests for additional functions and fixing bugs.

After the CWRMS website demonstration, S. Fisher reviewed how the Water Quality Exchange (WQX) is set 
up and how data can be uploaded. Although the ability to conduct a full demonstration of the WQX was not available, examples of the data types and the U.S. Environmental Protection Agency (EPA) Central Data Exchange website were shown and explained. Only a few PAC members felt that their agency's data could be fit into the WQX templates and uploaded for public use. The type of data, units, and mode of storage was mentioned again and needs to be addressed on an individual user basis.

Other topics of discussion throughout the day included:

- The Office of Planning and Development (OPD) is still planning on updating the SSER Comprehensive Management Plan (CMP) in the future

- The OPD plans to follow up on the action items set forth in the CWRMS with funding opportunities
- The OPD will look to continue collaboration with USGS and other partners/stakeholders studying the SSER

- There are data repositories other than EPA STORET that are more amenable to taking in continuous waterquality monitoring data

A brief review of "next steps" for creating the CWRMS and updating the project website was given at the end of the meeting.

USGS will be in contact with PAC members to provide updates on the CWRMS website and as the report is being drafted.

Meeting adjourned at 3:00 p.m.

\title{
U.S. Geological Survey
}

Project Advisory Committee (PAC) Meeting 3 for the Long Island South Shore Estuary Reserve (SSER)

Coordinated Water Resources Monitoring Strategy (CWRMS) project

The Suffolk Center

Molloy College

7180 Republic Airport, East Farmingdale, NY 11735

Thursday, October 27, 2016

8:30 a.m.-12:30 p.m.

Attending:

Staff:

\section{PAC Members:}

\author{
Shawn Fisher, U.S. Geological Survey (USGS) \\ Jason Finkelstein, USGS \\ Rob Welk, USGS \\ Jeremy Campbell, New York State Department of State (NYSDOS) Office of Planning and Development (OPD) \\ Sherry Forgash, NYSDOS OPD SSER Office \\ Lou Siegel, NYSDOS OPD SSER Office
}

James Browne, Town of Hempstead

Marty Byrnes, Town of Islip

Charles de Quillfeldt, New York State Department of Environmental Conservation (NYSDEC)

Maureen Dolan Murphy, Citizens Campaign for the Environment

Dan Fucci, Nassau County Department of Public Works

Rich Groh, Town of Babylon

Mike Jensen, Suffolk County Department of Health Services

Tom Marquardt, Town of Islip

Bob Nyman, U.S. Environmental Protection Agency (EPA)

Adam Starke, The Nature Conservancy

John Tanacredi, Molloy College

Phil DeGaetano, New England Interstate Water Pollution Control Commission

Ruth Coffey, Adelphi University

Evelyn Powers, Interstate Environmental Commission 
S. Fisher began the third Project Advisory Committee (PAC) meeting for the Coordinated Water Resources Monitoring Strategy (CWRMS) NYSDOS funded project at 9:19 a.m. The project was summarized and updates provided, including items covered at previous PAC meetings, a description of groundwater contributions to the bays, and a short explanation of the progress of the website and mapper. The agenda for the day's meeting was provided and included overview of the mapper and its current layers, discussion of review of the report chapters, including data gaps and recommendations, and outline of the final steps before publication.

The first draft of the CWRMS has been sent to approximately 90 PAC members. The plan is to provide the existing project website to NYSDOS to continue and maintain. Should the NYSDEC and NYSDOS decide to expand the mapper to the rest of Long Island as part of the NYSDEC Long Island Nitrogen Action Plan (LINAP), the USGS would leverage the existing work and maintain control of the site for an additional length of time.

S. Fisher mentioned the Water Quality Exchange/Portal as a way of archiving and preserving current and historical water-quality and certain ecological data.

$\mathrm{R}$. Welk led the interactive portion of the meeting with a demonstration on the features of the project website and mapper. Both the website and mapper are functional, but a newer version of the mapper is in the works and planned for release in the coming months. He explained that the future mapper will have filtering capabilities and be more effective at supporting management decisions and identifying data gaps as well as potential collaborative partnerships. Data will be searchable based on hydrologic unit codes, monitoring agency, constituents collected, and collection frequency. On the current map, different colors of dots on the mapper refer to the frequency of sampling while the shape of the point refer to type of site (for example, estuary, groundwater, stream) at which data are available. R. Welk provided more details about the information contained in the drop-down box that appears after clicking on one of the dots on the mapper. The data are generally presented in the mapper in the manner it is provided to USGS, but is subject to modification, if necessary. All datasets will be accessible; trying not to duplicate efforts.

J. Tanacredi noted that infrastructure should be included on the mapper, such as location of outfalls. S. Fisher replied that USGS has been actively pursuing these datasets from the towns and counties but has not yet obtained it. He also asked if U.S. Army Corps of Engineers (USACE) permits for dredging be identified on the mapper? R. Welk said the USACE has static PDFs available online with permit information, but no shapefiles are available. L. Siegel explained that a NYSDOS funded project, "Planning for Dredged Materials Management," may have shapefiles associated with it; these should be included on the CWRMS website. J. Browne said Town of Hempstead's historic dredging and borrow pit data are not available. R. Groh suggested including total maximum daily load (TMDL) waterbodies and uncertified shellfish waters on the website. S. Fisher noted that the shellfish areas could be included in the website, but that the information would only point to where open or closed shellfish areas could be found. The TMDL listing will indicate health of the bays concerning constituents, such as nitrogen and pathogens. USGS has the Priority Waterbodies List link on the website, which notes additional impairments.

J. Campbell asked if there is a mechanism or process for updating the data on the project website, specifically the mapper. J. Finkelstein noted that new datasets are added easily; obtaining the data from stakeholders can be difficult. R. Nyman said there should be a method for dating the database. Updates could pose a problem when the project ends, as it is unclear which parties will provide updates to the project website. It was suggested that perhaps USGS can update the data annually. S. Fisher said that USGS is trying to automate some data to dynamically link it to, as an example, EPA Storage and Retrieval (STORET). R. Nyman asked if there was a way that users could view the date of the most recent data accessed through the project mapper. J. Campbell notes that there is interest from NYSDEC and the LINAP project to expand the mapper for island-wide coverage. USGS will attempt to automate the website as much as possible.

L. Siegel described how there needs to be a mechanism (a system) to report to NYSDOS SSER Office and USGS, who is collecting data, what type of data are being monitored, when the data are being collected, and location of monitoring. All stakeholders should be reporting their work. It was suggested that a form (perhaps a web-based reporting system) should be sent to stakeholders to complete and submit to the SSER Office to help inform recommendations to monitoring programs and encourage coordination. R. Welk mentioned that the website forum is not being used as much as it could. R. Nyman commented on the need for a strategy for collection and use of data.

C. de Quillfeldt said that the next version of the SSER Comprehensive Management Plan (CMP) should include the projects that still need to be implemented. He also feels that the current draft of the CWRMS is lacking in some areas; it needs a better focus for sampling and it is missing some recommendations.

J. Tanacredi suggested that the CWRMS include land use issues/patterns, especially in the watersheds of Great South Bay. He cited the vast number (approximately 3,500) of new housing units and the potential for water-quality impacts.

R. Groh asked if a polygon layer for sewered versus unsewered areas would be added. C. DeQuillfeldt noted that most of the south shore of Suffolk County is not being sewered and that inland treatment plants discharge effluent to groundwater.

E. Powers asked if the mapper will have the capacity and the functionality to accommodate more layers. J. Finkelstein responded that more layers can be added if the data were provided. 


\section{CWRMS Chapter 1: Introduction'}

S. Fisher solicited comments from the PAC and informed them that comments can still be submitted.

J. Tanacredi wants to see an established ecological assessment of the bays with baseline data, such as inventories and indices, included in cdm chapter 1. L. Siegel reminded all that the 2001 SSER CMP includes numerous technical reports that were written to inform the CMP that provide baseline inventories. Additionally, The Nature Conservancy wrote a comprehensive report on the Great South Bay. The final watershed management plans contain the status of various areas within that particular watershed.

There was mention of the former duck farms and their legacy contribution to nitrogen impairments.

S. Fisher asked the PAC their opinion on including trophic state indicators (TSIs) and forcing functions in chapter 1. In the draft, these are both included in chapter 1, but they could possibly be separated and more information could be provided. No opposition to the draft's structure was expressed regarding this issue.

\section{CWRMS Chapter 2: Resource Monitoring in the Long Island South Shore Estuary Reserve}

C. de Quillfeldt suggested including the glass eel survey conducted by NYSDEC in Carmans River (and possibly Massapequa Creek).

S. Fisher described the report Table 6of instrumentation used for data collection by PAC members. The idea is to get a sense for what technology is available and whether is effective for measuring physical constituents. For chemical constituents, laboratory procedures are to be documented.

T. Marquardt noted the importance of monitoring waterquality post-aquaculture as being analogous to best management practices or green infrastructure (BMP). Environmental assessments and in situ nitrogen-removal studies should be conducted to understand the effectiveness of shellfisheries and other BMPs.

M. Dolan-Murphy suggested that a paragraph on ocean acidification is needed in the report - this is an urgent issue that could be addressed with a task force. $\mathrm{pH}$ data are a major gap. A gap also exists regarding microplastics in the SSER (loads, in the sediment, in marine life, etc.).

The NYSDEC provides for monitoring air resources. Nassau and Suffolk Counties have had increased ozone levels. Data on contribution of atmospheric nitrogen to the estuary is needed.

Partial pressure of carbon dioxide is a data gap. This is not easy to measure. J. Browne noted that Town of Hempstead has the capacity to measure it but needs funding.

${ }^{1}$ Chapter numbers are not included in the finalized CWRMS.
CWRMS Chapter 3: Quality Assurance and Quality Control, Metadata, and Data Archives

Other groups who do monitoring through their own grants should be encouraged to move that data to a national registry.

J. Campbell noted that the NYSDEC will not use data from citizen science groups without a quality assurance project plan (QAPP).

The EPA can assist groups in writing a QAPP.

S. Fisher described a ranking system that the State of Indiana uses to indicate the degree of quality assurance and quality control (QA/QC) associated with monitoring program. Data can be described as tier 1, tier 2, or tier 3, with ascending numbers indicating a higher level of data. For example, only tier 3 is used by the NYSDEC for regulatory purposes. At this point, a discussion on QA/QC developed. J. Tanacredi expressed concern that monitoring programs without a QAPP (and tier 3) status were not useful. A. Starke and others insisted that all data are important, and that tier 1 and tier 2 are necessary as ways of identifying waterbodies of concern. J. Campbell suggested contacting the NYSDEC to discuss the process of citizen science and academia developing QAPPs. The QAPPs provide consistency in sampling data for the Protected Waterbodies List.

S. Fisher expressed the necessity of collecting and preserving metadata. A good example is the National Park Service (NPS) Integrated Resource Management Applications (IRMA), which keeps all programs organized so information can be made available. This method for documenting and archiving studies, data, and metadata conducted within NPS boundaries would be a good model for future SSER Office record keeping (as mentioned earlier in the meeting)

\section{CWRMS Chapter 6: Coordinated Water Resources Monitoring Strategy Website}

S. Fisher noted that most of this was discussed earlier in the meeting, and there were no additional comments.

\section{CWRMS Chapter 4: Data Gaps and Specific Recommendations}

S. Fisher asked the PAC to review and complete the data gap questionnaire, which will rank each listed gap as high, medium, or low priority based on their organizations' missions.

Some PAC members asked if any monitoring was done on land, for example, the mapping of, or monitoring at, stormwater outfalls. The towns had to complete the mapping of stormwater outfalls as part of the municipal separate storm sewer system (MS4) program. Stormwater outfall information is available. S. Fisher noted that a suggestion was made during the individual meetings to use citizen science and Global Positioning System (GPS) to locate all storm drains and to store this data in one central location. 
J. Tanacredi reiterated the need for a complete inventory of the ecosystem health of Great South Bay.

S. Fisher explained that USGS aim in this chapter is to capture all the recommendations of the PAC and include them in the report tables. L. Siegel suggested converting the tables to Microsoft Access; but S. Fisher said this cannot be done, as USGS is required to present their information in a basic format that is accessible by all, and not everyone who will need this data has the Access program (and even the Microsoft Excel files currently used will be converted to CSV). That said, an Access database can be created and maintained by the SSER Office for continued use.
CWRMS Chapter 5: General and Coordination Recommendations From the Project Advisory Committee

J. Tanacredi stated that he has made comments, and in particular on page 55 of the draft CWRMS; these comments will be presented to the USGS for incorporation.

J. Campbell reminded the PAC that there is a link to all the Governor's Office of Storm Recovery (GOSR) NY Rising Community Reconstruction plans on the NYSDOS website: http://www.stormrecovery.ny.gov/community-regions/ long-island.

A. Starke asked if economic information would be included, such as catch rates. J. Campbell expressed that this would be part of the CMP instead.

The PAC meeting concluded at 12:13 p.m. 

For more information about this report, contact: Director, New York Water Science Center

U.S. Geological Survey

2045 Route 112, Building 4

Coram, NY 11727

dc_ny@usgs.gov

(518) 285-5602

or visit our website at

https://ny.water.usgs.gov

Publishing support provided by the

Pembroke Publishing Service Center 


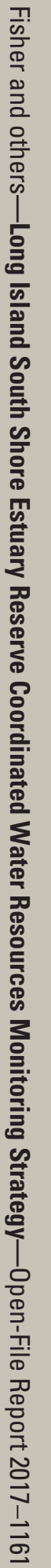

